Historic, Archive Document

Do not assume content reflects current scientific knowledge, policies, or practices. 

62.11

Che I. A. Cuatkins Mdse. Co.

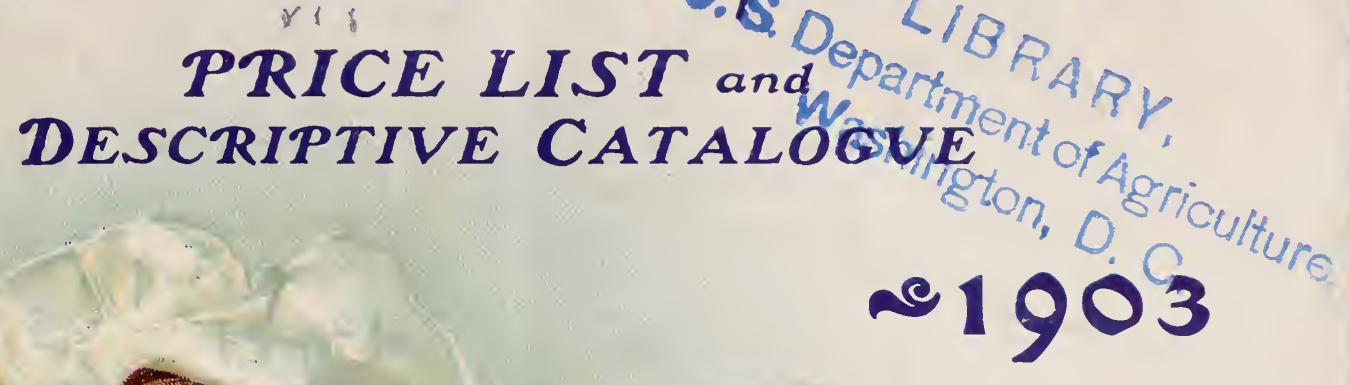

field, flower Garden Seeds
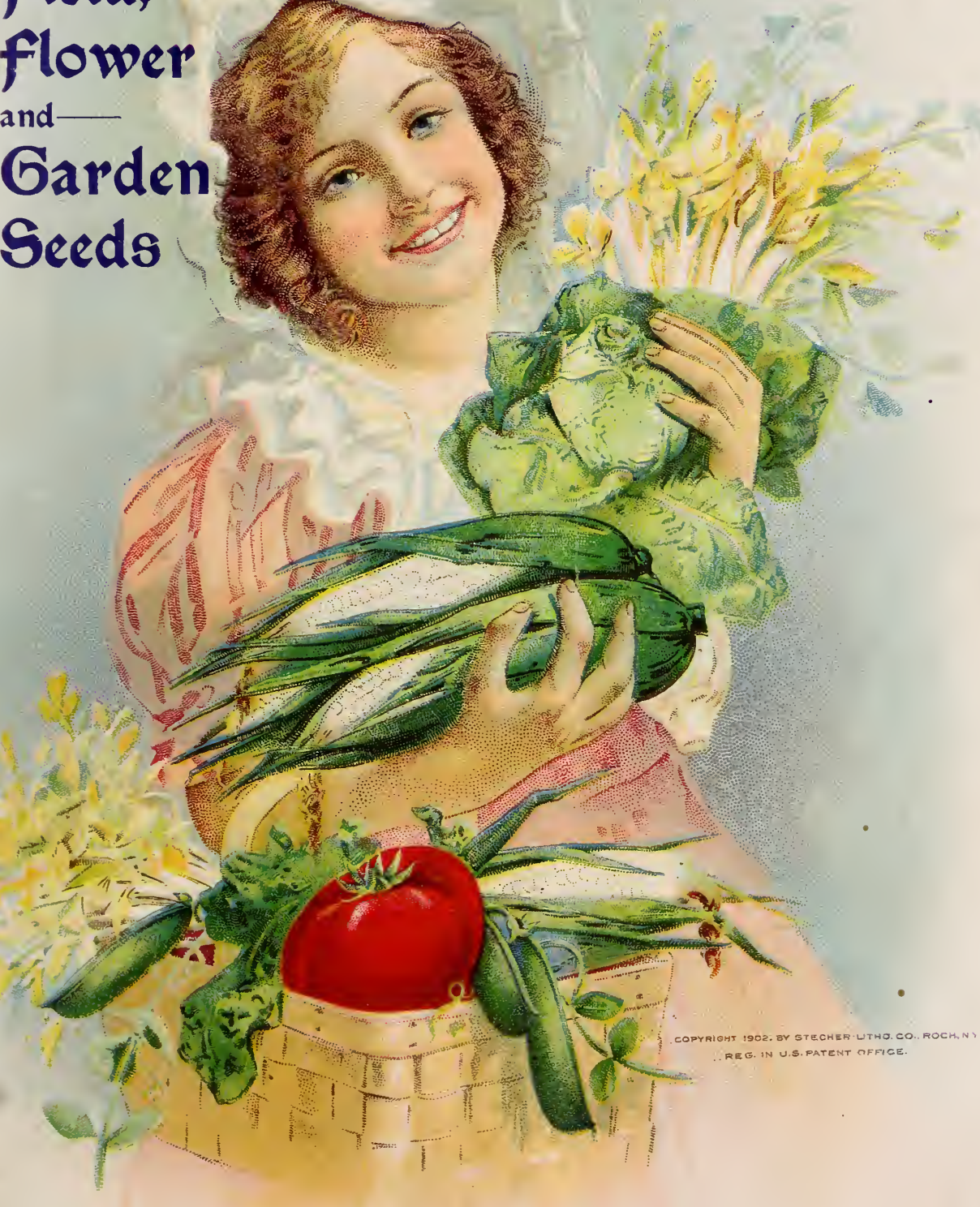

\section{Denver, Colo.}

Office and Store:

1525 to 1531 Cazaze Street,
Carehouses :

1600 to 1630 Seventh Street. 


\section{TO OUR FRIENDS AND PATRONS.}

It is with pleasure that we hand you our Annual Seed Catalogue, which you will find as complete as any issued. We have spared neither pains nor expense to obtain the best seeds in the market, knowing the importance of planting good and reliable seeds. Our stock has been selected from the best growers in the United States and Europe, and are all of THIS YEAR'S CROP, AND, CONSEQUENTLY, AS FRESH AS CAN BE. Our foreign seeds are imported by us direct to Denver, and are carefully selected from the different countries where specialties are made of the different classes and varieties, under the personal supervision of our c'wn seedsman, who is one of the most careful and best-posted men in his line in the west, having had years of experience at home and abroad. Extra care has ben taken to see that all seeds are true to name, and the best of their kind. We take the very best of care in packing seeds for shipment. All orders will be promptly shipped on the day the order is received.

We are satisfied that the stock of seeds we offer is the best that money can buy, and we are confident that a trial of our seeds will secure your future patronage.

Our terms are strictly cash with the order. WE DO NOT SEND SEEDS C. O. D.

\section{HOW TO ORDER.}

Write your name, postoffice, state and express office plainly, use the order sheet attached to this catalogue, and state thereon whether you wish the goods shipped by mail, express or freight. Order early. Do not wait until the rush of planting time. We strive to fill orders promptly and at short notice, but a rush season always and everywhere has its inevitable delays. First come will be first served.

\section{HOW TO SEND MONEY.}

Send cash with order; we do not keep any Book Accounts in the Mail Department. Customers will, therefore, please enclose the necessary amount in currency, stamps, postal note, postoffice money order or express order, whichever is most convenient. We will take two-cent stamps in any amount. Registered letters are generally very safe, and you can send that way from any postoffice, and receive your receipt by return mail, by which you know it has reached us. Make money order payable to The L. A. Watkins Mdse. Co.

With every dollar order for Vegetable or Flower Seeds in packets, selected from this catalogue, you may select seeds in packets amounting to $\$ 1.25$. On all orders for Garden Seeds, in ounce, quarter-pound and pound packages, amounting to $\$ 10.00$ and upwards, we will allow a discount of 10 per cent. for cash. No discount for prices on 5 pounds, 10 pounds or 15-pound lots.

Some seeds are scarce this season, and the market price is higher than usual. These include Peas, Beans, Cucumbers and Corn. But our prices on all seeds are as low as the market permits, for good, reliable seeds; and poor seeds are dear, even as gifts.

\section{GUARANTEE.}

Seeds of the best quality are apt to fail through improper treatment, by sowing the seed too deep or too shallow, in too wet or too dry soil. They differ greatly as to the temperature required for germination. Some will germinate rapidly at a certain temperature, while others, if sown under the same conditions, are apt to decay; and for all these reasons it is impractical to guarantee seeds. Consequently we give no warranty, expressed or implied, as to description, quality, productiveness or any other matter, of any seeds, bulbs or plants we send out, and we will not be in any way responsible for the crop. If the purchaser does not accept the goods on these terms, they are at once to be returned.

Hoping that all our friends and customers will patronize us in this new branch of our business, as they have in the past, feeling satisfied that they will get from our hands the best that money can buy, and wishing them a prosperous season, we remain,

Yours respectfully,

THE L. A. WATKINS MERCHANDISE CO. 


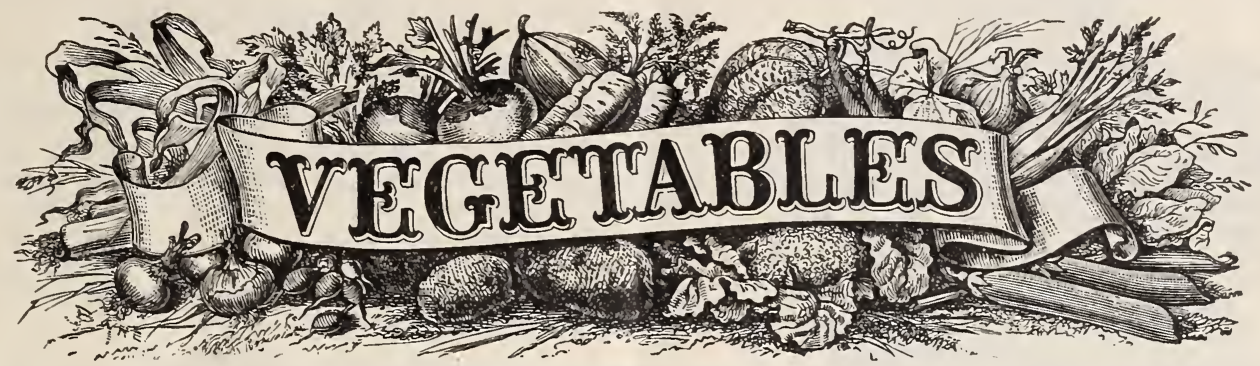

ON SEEDS ORDERED IN PACKETS AND OUNCES, YOU MAY SELECT SEEDS AMOUNTING TO \$1.25 FOR EVERY \$1.00 SENT.

ON ALL ORDERS FOR GARDEN SEEDS, IN OUNCE, QUARTER POUND AND
POUND PACKAGES, AMOUNTING TO \$10.00 AND UPWARDS, WE WILL ALLOW A DISCOUNT OF IO PER CENT. FOR CASH.

ON PACKETS, OUNCES AND QUARTER POUNDS, POSTAGE FREE.

\section{ARTICHOKE.}

Artichaut-Artischoke.

Sow in April in rich soil, and transplant the following spring to permanent beds (in rows or hills), three feet apart and two feet between the plants. They only give a partial crop the first season, but the beds will remain in bearing for years. Protect in winter by a covering of leaves or coarse manure.

LARGE GREEN GLOBE.-Produces large, globular heads; scales green shading to purple, best for general use. This is the French Artichoke, which is so highly esteemed in Europe, and especially in the Paris Market. Pkt., 5c; oz., 25c; 1/4 lb., 75c; lb., $\$ 2.50$.

JERUSALEM.-Tubers in season. 10c per lb.

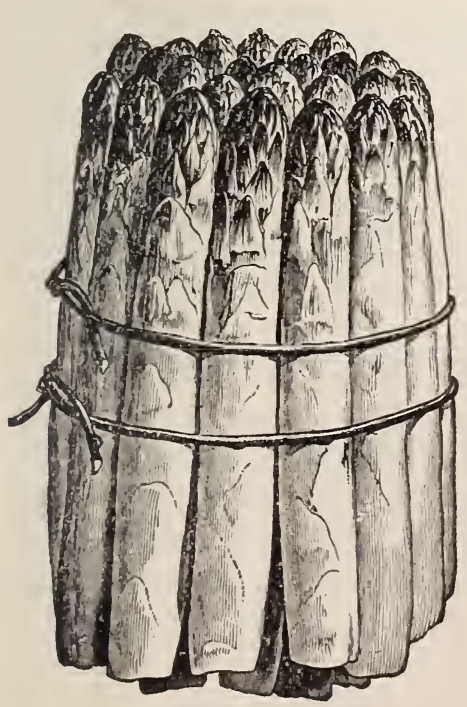

Asparagus.

\section{ASPARAGUS.}

\section{Asperge-Esparrago-Spargel.}

One ounce will sow about 50 feet of drill for transplanting and produce about 300 plants.

The seed should be sown in March or April, just as soon as the ground can be worked, in good, rich, mellow soil, in drills one foot apart, then covered with earth from one-half to three-quarters inch deep.

CONOVER'S COLOSSAL.-The standard variety; of large size, tender and of excellent quality. Pkt., 5c; oz., 10c; $1 / 4$ lb., $15 \mathrm{c} ; 1 \mathrm{lb} ., 50 \mathrm{c}$.

PALMETTO.-It is of very large size, even and regular in growth and appearance. It is a very early sort and immensely productive, and of the best quality. Pkt., 5c; oz., 10c; $1 / 41 \mathrm{lb} ., 20 \mathrm{c}$; $1 \mathrm{lb} ., 65 \mathrm{c}$.

COLUMBIAN MAMMOTH WHITE.-A new and entirely distinct variety, that produces shoots that are white, and remain white as long as fit for use. In addition to this advantage it is more robust and vigorous in habit, and requires no earthing up, as in the green sorts, in order to furnish the white shoots so much sought after. Pkt., 5c; oz., 10c; 1/4 lb., 25c; lb., $75 \mathrm{c}$. 
If by mail, postage must be added at the rate of 8 cents per pound. On packets, ounces and quarter pounds, postage free.

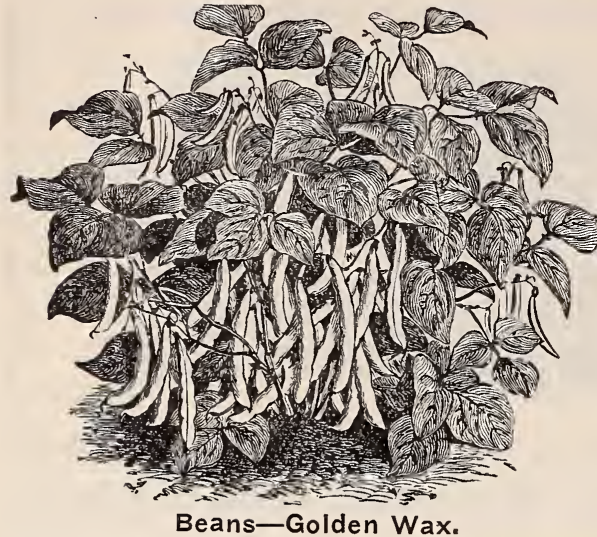

BEANS. Dwarf or Bush Varieties.

Haricots Nains-Frijoles-Busch oder Brech-Bohnen.

A succession of sowings can be made from the first week in May until August. Plant in drills about two inches deep and from eighteen inches to two feet apart, according to the richness of the soil-the poorer the soil, the closer they can be planted; the plants should be about three inches apart. One pound to 50 feet of drill; one hundred pounds to an acre.

\section{GREEN POD VARIETIES.}

IMPROVED EARLY RED VALENTINE.-Pods develop to an edible condition in thirty-two days from germination. Color of Pods, light green and semi-transparent. Form of pods, round and slightly curved. Succulent, prolific, and quite free from strings, continuing long in edible condition. Pkt., 5c; 1/2 lb., 10c; per lb., 15c; per 2 lbs., $25 \mathrm{c}$; per 10-lb lots, $\$ 1.00$.

EARLY, ROUND, YELLOW-SIX WEEKS.-An early, snap-short variety, producing edible pods thirty days after germination. Very bushy; erect; pods long, flat, straight. Pkt., 5c; 1/2 1b., $10 \mathrm{c} ; 1$ lb., 15c; 2 lbs., 25c; 10-lb. lots, $\$ 1.00$.

EXTRA EARLY REFUGEE.-A very early, green podded kind, furnishing a fleshy pod of fine quality. The vines are a little smaller and more upright growing, and the leaves distinctly lighter colored than those of the late Refugee, though the dry beans are much the same in shape and color. All the vines ripen their pods well together and long before those of the common Refugee are usable. Pkt., 5c; 1/2 lb., 10c; 1 lb., 15c; 2 lbs., 25c; per 10-1b. lots, \$1.00.

BEST OF ALL.-Pods long, very fleshy, succulent, stringless and of rich flavor; are produced early and abundantly; one of the most valuable green podded beans for market or family use. Per Pkt., 5c; $1 / 2$ lb., 10c; 1 lb., 15c; 2 lbs., 25c; per 10-lb. lots, $\$ 1.00$.

DWARF HORTICULTURAL.-Vine vigorous, productive, half early. Pods and beans similar to the Tall Horticultural, and the green beans equally good. Pkt., $5 \mathrm{c} ; 1 / 2 \mathrm{lb} ., 10 \mathrm{c} ; 1 \mathrm{lb} ., 15 \mathrm{c} ; 2 \mathrm{lbs} ., 25 \mathrm{c} ;$ 10-lb. lots, $\$ 1.00$.

WHITE MARROWFAT.-Extensively grown for sale in the dry state. Pkt., 5c; $1 / 2$ 1b., 10c; $1 \mathrm{lb}$., $15 \mathrm{c}$; 2 lbs., 25c; 10-lb. lots, $\$ 1.00$.

\section{BEANS.}

\section{WAX POD VARIETIES.}

VALENTINE WAX.-This is a new bean of great merit. It is, without exception, the earliest wax bean in cultivation. The pods are very meaty and with so very little string that they may justly be called stringless. It is remarkably free from rust and is the best in quality for snap bean of any wax bean in use. Per pkt., 5c; $1 / 2$ 1b., 10c; 1 lb., 15c; 10-1b. lots, $\$ 1.25$.

IMPROVED GOLDEN WAX.-Possesses all the good points of the old Golden Wax, but is larger in pod and much more prolific; of tender, melting flavor at all stages of its growth. Per pkt., 5c; $1 / 2$ lb., 10c; 1 lb., 15c; 10-lb. lots, $\$ 1.25$.

IMPROVED REFUGEE WAX.-New stringless strain. This new variety is one of the earliest beans grown. It is a perfect Refugee, with wax pods that are long, round and of golden yellow color. It is suitable for early or late sowing, and when sown in the spring it will give seed in time for a second crop in the fall. It is an immense yielder. Per pkt., $5 \mathrm{c} ; 1 / 21 \mathrm{~b} ., 10 \mathrm{c} ; 1 \mathrm{lb} ., 15 \mathrm{c} ; 10-1 \mathrm{~b}$. lots, $\$ 1.25$.

CHALLENGE BLACK WAX.-A very prolific strain of wax beans; fine round pods, flavor excellent; earlier tnan the ordinary Black Wax, and not so apt to rust. Per pkt., 5c; 1/2 10., 10c; $1 \mathrm{lb} ., 15 \mathrm{c}$; 10 -lb. lots, $\$ 1.25$.

DWARF BLACK WAX,-A very superior snap short wax bean; ripening among the first earliest, and having the best characteristics. Pods round, yellowish white, flne flavor. Per pkt., 5c; $1 / 2$ lb., $10 \mathrm{c} ; 1 \mathrm{lb} ., 15 \mathrm{c} ; 10-\mathrm{lb}$. lots, $\$ 1.25$.

WARDWELL'S KIDNEY WAX.-This new variety is very hardy and productive; pods long, broad, flat and of delicate waxy yellow, brittle and entirely stringless, and very early. Per pkt., 5c; 1/2 lb., $10 \mathrm{c} ; 1$ lb., 20c; 10-lb. lots, $\$ 1.50$.

FLAGEOLET WAX.-A large, bush wax variety; seed large; purplish red; excellent as a snap bean, and in great favor as a dry shell bean. Per pkt., 5c; $1 / 2$ lb., 10c; 1 lb., 15c; 10-1b. 1ots, $\$ 1.25$.

\section{BEANS-Pole or Running.}

EARLY JERSEY LIMA.-Early and productive, and one of the best lima beans grown. Pkt., 5c; $1 / 2$ lb., $15 \mathrm{c} ; 1$ lb., 20c; 2 lbs., 35c. 
If by mail, postage must be added at the rate of $s$ cents per pound.

On packets, ounces and quarter pounds, postage free.

LAZY WIFE.-Immensely popular everywhere. It is exceedingly productive, and easily gathere 3. Probably this is why it comes by its very discourteous name. It is an excellent bean. Pkt., 5c; $1 / 2$ lb., 15c; 1 lb., 20c; 2 lbs., 35c.

KENTUCKY WONDER.-Vine vigorous, climbing well and very productive, bearing its pods in large clusters; blossoms white; pods green, very long, often reaching nine or ten inches, nearly round when young, and very crisp. Pkt., 5c; 1/2 lb., 15c; 1 lb., 20c; 2 lbs., 35c.

SCARLET RUNNER OR FLOWERING BEAN.-A great favorite; both ornamental and useful; height, 10 feet, presenting dazzling scarlet flowers from July to October. Used both as a string bean and shelled. Plkt., 5c; 1/2 lb., 15c; 1 lb., 25c; 2 lbs., $40 \mathrm{c}$.

\section{BEANS.-Bush Lima.}

HENDERSON'S BUSH LIMA.-This is a bush form of the small Seiva pole bean. It is the most productive of any, and, on the whole, is a vegetable of great merit. Pkt., 5c; $1 / 21 \mathrm{~b} ., 15 \mathrm{c} ; 1 \mathrm{lb} ., 20 \mathrm{c} ; 2$ lbs., $35 \mathrm{c}$.

BURPEE'S BUSH LIMA.-The only bush form of the true, luscious, large Lima. It is pronounced by all good judges as unquestionably the real Bush Lima. The bushes grow eighteen to twenty inches high; of stout growth and always erect. It is an immense yielder, the pods being filled with very large beans. Plit., 5c; 1/2 lb., 15c; 1 lb., 20c; 2 lb., 35c.

\section{BEANS.-English or Broad.}

BROAD WINDSOR.-Best for general use. Pkt., 5c; $1 / 21 \mathrm{~b} ., 15 \mathrm{c} ; 1 \mathrm{lb} ., 20 \mathrm{c}$.

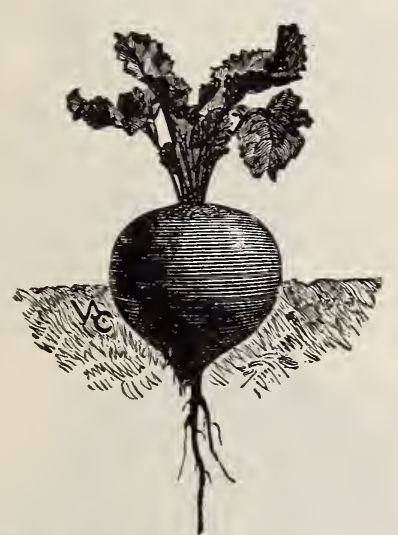

Beet-Dewing's Blood Turnip.

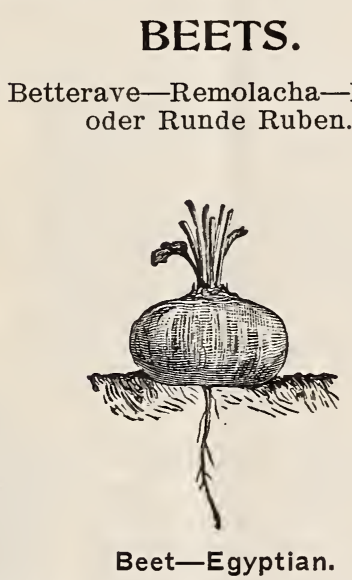

Beet-Egyptian.

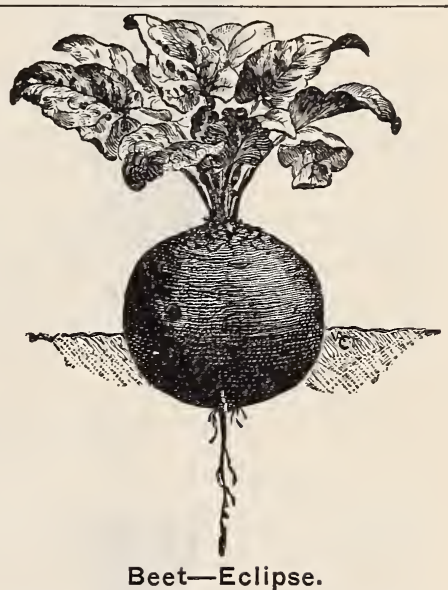

Beet-Eclipse.

Beets require a deep, rich, mellow soil, and may be sown from early spring to commencement of summer. Drop about one inch deep, in drills twelve to eighteen inches apart. One ounce to 50 feet of drill: six pounds to an acre.

EARLY BLOOD RED TURNIP.-Here we have the old stand-by, the turnip beet, with its dark red color, well known to so many homesteads; suffice it to say, it is the best variety for family use. Pkt., 5c; oz., 10c; 1/4 1b., 20c; 1 lb., 50c.

DEWING'S EARLY BLOOD TURNIP.-Roots deep blood red, of fine form and flavor; very early. Per oz., 10c; $1 / 4$ lb., 20c; 1 lb., 50c.

EDMAND'S EARLY BLOOD TURNIP.-The best sort for general crop. In quality one of the finest; exceedingly dark; shape, globular, having only one tap root. Very popular with market men. Per oz., 10c; 1/4 lb., 20c; 1 lb., 50c.

EXTRA EARLY EGYPTIAN.-A very popular early variety. Has small tops, and grows quickly; roots very dark red, rounded on top, but flat beneath; crisp and tender. Pkt., 5c; oz., 10c; 1/4 1b., $20 \mathrm{c} ; 1$ lb., 60c.

CROSBY'S EGYPTIAN.-The earliest beet in the market, being more globular than its parents, the Early Egyptian. It is of deepest red, almost black in color, and, without doubt, one of the very best for market gardeners. Pkt., 5c; oz., 10c; 1/4 lb., 20c; 1 lb., 60c.

ECLIPSE.-It is as early as the Egyptian; flesh very tender; roots nearly globular, with a small tap root; very sweet, and dark blood color. It is very desirable tor market gardeners on account of its extreme earliness, as well as its other numerous good qualities. Plkt., 5c; oz., 10c; 1/4 1b., $20 \mathrm{c} ; 1$ lb., 60c.

HALF LONG BLOOD.-One of the best for winter use. The roots are only half as long as the Long Blood, but weigh as much on account of their thickness. They are always smooth and handsome, and their rich, dark red flesh is very sweet, crisp and tender. Pkt., 5c; oz., 10c; 1/4 1b., 20c; $1 \mathrm{lb} ., 50 \mathrm{c}$.

IMPROVED LONG BLOOD.-Excellent for winter use; smooth-skinned; flesh dark red. Per oz., $10 \mathrm{c} ; 1 / 4 \mathrm{lb} ., 20 \mathrm{c} ; 1 \mathrm{lb} ., 50 \mathrm{c}$. 
If by mail, postage must be added at the rate of 8 cents per pound.

On packets, ounces and quarter pounds, postage free.

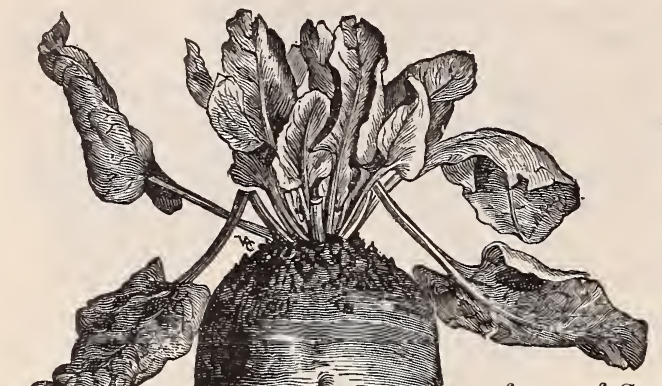

SWISS CHARD OR SILVER BEET.-A distinct vegetable, and much superior to the common beets for greens. If sown at the same time, it will be fit to use before them. Plkt., 5c; oz., 10c; $1 / 4$ lb., 25c; $1 \mathrm{lb}, 75 \mathrm{c}$.

\section{SUGAR BEETS}

\section{and Mangel Wurzels for Stock Feeding.}

Mangels and Sugar Beets for stock, 4 to 6 pounds per acre. If for sugar factory, 12 to $20 \mathrm{lbs}$. lb.

Any of the following varieties in 5 -1b. lots at $25 \mathrm{c}$ per

SILESIAN SUGAR.-This is the old, well-known ugar Beet long raised in this country, for feeding stock mostly. Per oz., 5c; 1/4 lb., 10c; 1 lb., 30c.

VILMORIN'S IMPROVED SUGAR.-In general, the most desirable beet for the factory is the one containing the largest percentage of sugar. In this variety we have one of the richest beets in cultivation. In size it is medium or little below, yielding from ten to fifteen tons per acre, and containing from sixteen to eighteen per cent. of sugar. Oz., 5c; 1/4 lb., 15c; $1 \mathrm{lb} ., 35 \mathrm{c}$.

LANE'S IMPERIAL SUGAR.-Goođ for making sugar, also stock feeding. A hardy and productive sort. Yields fourteen to sixteen tons per acre, and contains about sixteen per cent. of sugar. Oz., 5c; 1/4 lb., 15c; 1 lb., 35c.

KLEIN WANZLEBEN.This variety has proved to be a very valuable sort; a little larger than Vilmorin's Improved, yielding from twelve to eighteen tons, and containing about the same amount of sugar. It grows below the surface, and the green leaves are rather large and spreading, with wavy edges. Oz., $5 \mathrm{c} ; \mathrm{t} / 4 \mathrm{lb} ., 15 \mathrm{c} ; 1 \mathrm{lb} ., 35 \mathrm{c}$.

YELLOW GLOBE.-Globular shaped roots; more productive than long red in shallow soil; very nutritious, and a good keeper. Oz., 5c; $1 / 4$ lb., 15c; 1 lb., 35c.

YELLOW OVOID, OR INTERMEDIATE.-Root ovoi\}, intermediate between the long and the Globe varieties. Vigorous and productive; one of the best mangels for Colorado soil. Oz., 5c; $1 / 4$ lb., 15c; 1 lb., 35c. GOLDEN TANKARD

-Shape, cylindrical; color, deep, rich yellow; flesh yellow, circled with? white. Unequalled for feeding stock. It is an enormous cropper. Oz., $5 \mathrm{c} ; 1 / 4$ lb., $15 \mathrm{c} ; 1 \mathrm{lb} ., 35 \mathrm{c}$. MAMMOTH LONG RED. - A particularly fine stock of Mangel. The roots attain enormous size, smooth and regular in shape. It grows well a bove ground and is easily pulled. Oz., $5 \mathrm{c} ; 1 / \mathrm{s}$ lb.,

Mangel Wurzel-Yellow Ovoid. $15 \mathrm{c} ; 1$ 1b., $35 \mathrm{c}$.

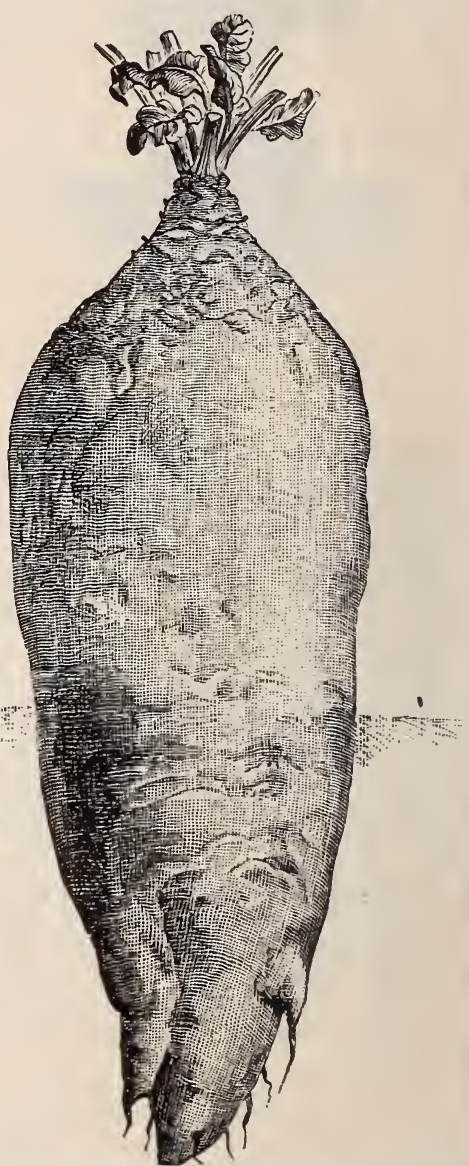

Mangel Wurzel-Mammoth Long Red. 
If by mail, postage must be added at the rate of 8 cents per pound.

On packets, ounces and quarter pounds, postage free.

\section{BROCCOLI.}

Chou-Brocoli d'hiver-Broculi-Spargelkohl.

Nearly allied to the Cauliflower, but more hardy. It succeeds best in a moist and rather cold atmosphere.

LARGE WHITE MAMMOTH.-A valuable variety, with very large, firm heads. Pkt., 5c; oz., 35c; $1 / 4$ lb., $\$ 1.00$.

\section{BRUSSELS .SPROUTS.}

Chou de Bruxelles-Bretones de Bruselas-Rosen Kohl-Kohl-sprosser.

This is one of the best vegetables for winter use, producing from the axils of the leaves an abundance of sprouts resembling small cabbages; of excellent, mild flavor. It is a delicacy much esteemed in Europe. Sow in seed-bed middle of spring, and trainsplant and manage as winter cabbage.

DWARF IMPROVED.-A variety prołucing compact sprouts of excellent quality. Pkt., 5c; oz., $15 \mathrm{c} ; 1 / 4 \mathrm{lb} ., 50 \mathrm{c} ; 1 \mathrm{lb} ., \$ 1.50$.

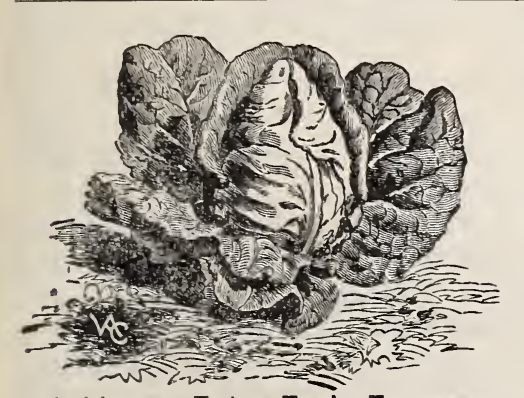

Cabbage-Extra Early Express.

\section{BORECOLE OR KALE.}

\section{Chou-vert-Kraus oder Blatter Kohl.}

Kale may be grown in almost any soil, but the richer it is, the more abundant the product. Sow from the middle of April to the beginning of May in prepared beds, transplant in June, and treat in the same manner as for cabbage. $1 \mathrm{oz}$. to 2,000 plants.

DWARF GREEN GERMAN.-Leaves yellowish green; very compact and beautifully curled. Sow in September for winter and early spring use. Plit., $5 \mathrm{c}$; oz., $10 \mathrm{c}$; $1 / 4$ lb., $30 \mathrm{c}$.

TALL GREEN CURLED SCOTCH.-This is one of the most popular varieties. It is very hardy and is much improved by frost. Two feet high. Plit., 5c; oz., 10c; 1/4 lb., 30c.

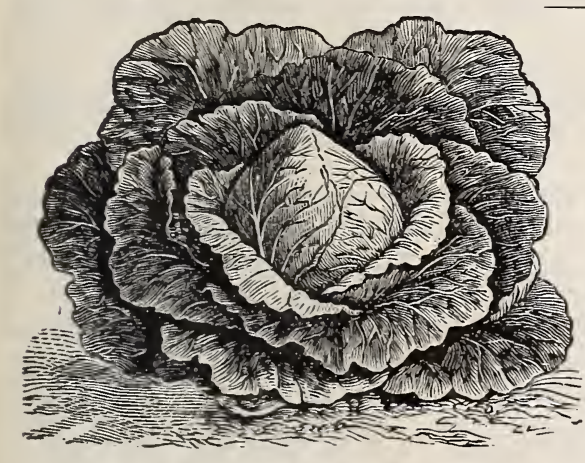

CABBAGE.

\section{Chou-Pomme-Berza de repollo-Kopfkohl.}

The ground must be highly manured, deeply dug or plowed, and thoroughly worked to insure good, full-sized heads. A heavy, moist and fresh loam is most suitable. The early sort should be sown very early in hot-beds, hardened off and transplanted early in the spring. One ounce produces 2,500 plants.

EXTRA EARLY EXPRESS or WONDERFUL.-Produces air-sized heads in eighty to eighty-five days from sowing the seed. An important acquisition for the market garlener and those growing cabbage for early market. Does not form as hard head as the Early Wakefield but is one week earlier. Pkt., 5c; oz., 25c; 1/4 lb., 75c; 1 lb., $\$ 2.25$.

EXTRA EARLY ETAMPES.-One of the earliest cabbages, producing well-formed, conical heads, remarkably

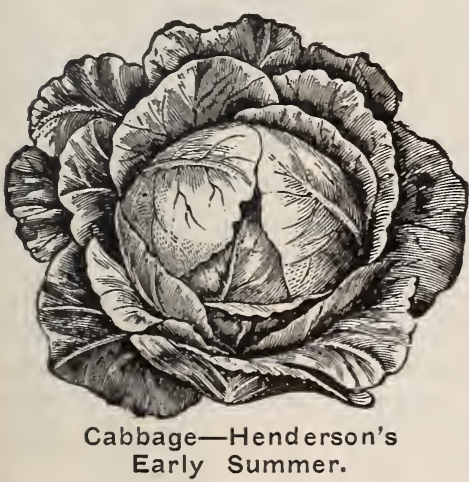
large for so early a ripener; forms a larger head than the Express, but not quite so early. Pkt., 5c; oz., 25c; 1/4 1b., $75 \mathrm{c} ; 1$ lb., $\$ 2.00$.

TRUE JERSEY WAKEFIELD.-The best early cabbage in cultivation. It forms fine, solid heads of good size; conical in shape, with very few outside leaves. We offer this as the earliest strain of this standard variety. Grown only from selected heads; warranted to give satisfaction. Pkt., $5 \mathrm{c}$; oz., 25c; $1 / 4 \mathrm{lb} ., 75 \mathrm{c} ; 1 \mathrm{lb}$.. $\$ 2.25$.

EARLY SPRING.-The earliest flat-ieared variety. Yields one-third more than the early pointed heads. Solir, unitorm and finely grained heads; stem is short and extends but little into the head, and is nearly as early as the Wakefield, and one of the most profitable sorts for early market. Pkt., $5 \mathrm{c}$; oz., $25 \mathrm{c} ; 1 / 4 \mathrm{lb}$., $75 \mathrm{c} ; 1$ lb., $\$ 2.50$.

HENDERSON'S EARLY SUMMER.-This standard variety 
If by mail, postage must be added at the rate of 8 cents per pound.

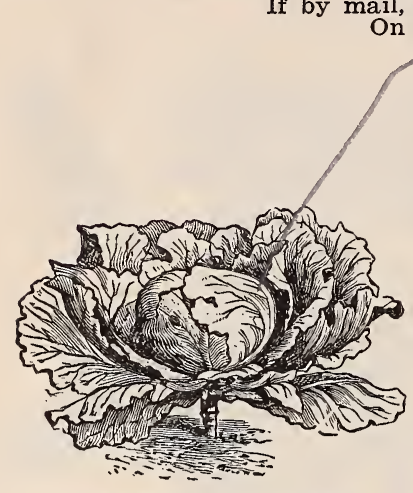

Cabbage-Surehead.

\section{CABBAGE-Continued.}

comes after the Wakefield, but being fully double in size; it may be classed as the best large early cabbage, and its short outer leaves enable it to be planted very close. Pkt., $5 \mathrm{c}$; oz., $25 \mathrm{c}$; $1 / 4 \mathrm{lb}$., $75 \mathrm{c} ; 1 \mathrm{lb}$., $\$ 2.00$.

ALL SEASONS.-A fine variety for any season; of good shape and size; a little later than the Early Summer. Pkt., 5c; oz., 25c; $1 / 4$ lb., $75 \mathrm{c} ; 1 \mathrm{lb} ., \$ 2.00$.

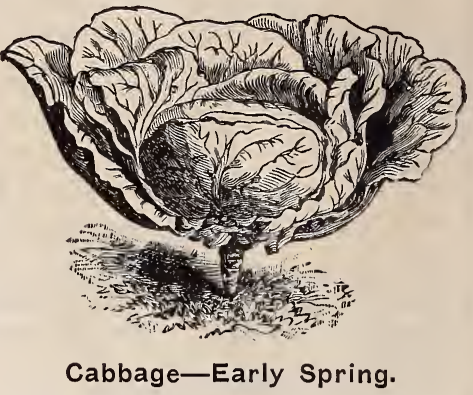

Cabbage-Early Spring.

EARLY WINNINGSTADT.-One of the best for general use, being very hardy and surehead, in season very close to the Wakefield; heads regular conical; very hard, and keep well both summer and winter. Pkt., $5 \mathrm{c}$; oz., $20 \mathrm{c} ; 1 / 4 \mathrm{lb}$., $60 \mathrm{c} ; 1 \mathrm{lb} ., \$ 2.00$.

EARLY YORK.-Heads small, heart-shaped, firm and tender; second early. Pkt., 5c; oz., 15c; $1 / 4$ lb., 40c; $1 \mathrm{lb} ., \$ 1.50$.

EARLY DWARF FLAT DUTCH.-An early cabbage of good size. Heads are flat and very solid. This is one of the best of second early kinds. Pkt., 5c; oz., 20c; $1 / 41 \mathrm{lb} ., 60 \mathrm{c} ; 1 \mathrm{lb}$., $\$ 2.00$.

DANISH BALL HEAD, or HOLLANDER CABBAGE.-The favorite winter cabbage with Colorado market gardeners. It is as hard as rock, and a small head will weigh as much as a large head of any variety. It grows very compact, thus yielding a much larger crop. It will stand long journeys, and keep far into the spring, and is most rich and mild in taste. This splendid shipping cabbage is also sold under the name of "Solid Emperor," or "German Export." Pkt., 5c; oz., 25c; 1/4 1b., 75c; 1 lb., \$2.50.

FOTTLER'S IMPRIVED BRUNSWICK.-It forms large, solid heads. It is low on the stump, weighing from ten to fifteen pounds each and a very valuable variety. Pkt., $5 \mathrm{c} ; 0 \mathrm{oz}, 20 \mathrm{c} ; 1 / 4 \mathrm{lb} ., 60 \mathrm{c}$; 1 lb., $\$ 2.00$.

SUREHEAD.-This sort produces large, round, flattened heads which are of uniform size, very hard, and of fine texture, and weigh from ten to fifteen pounds. It is a good keeper and shipper, of fine quality and certain to head, even in unfavorable season. Pkt., $5 \mathrm{c} ;$ oz., $20 \mathrm{c} ; 1 / 41 \mathrm{~b} ., 60 \mathrm{c} ; 1 \mathrm{lb}$., $\$ 2.00$.

PREMIUM rLAT DUTCH.-This variety of late cabbage is a standard in all sections for winter use. It makes a large, solid head which keeps long without bursting, and is adapted to a more

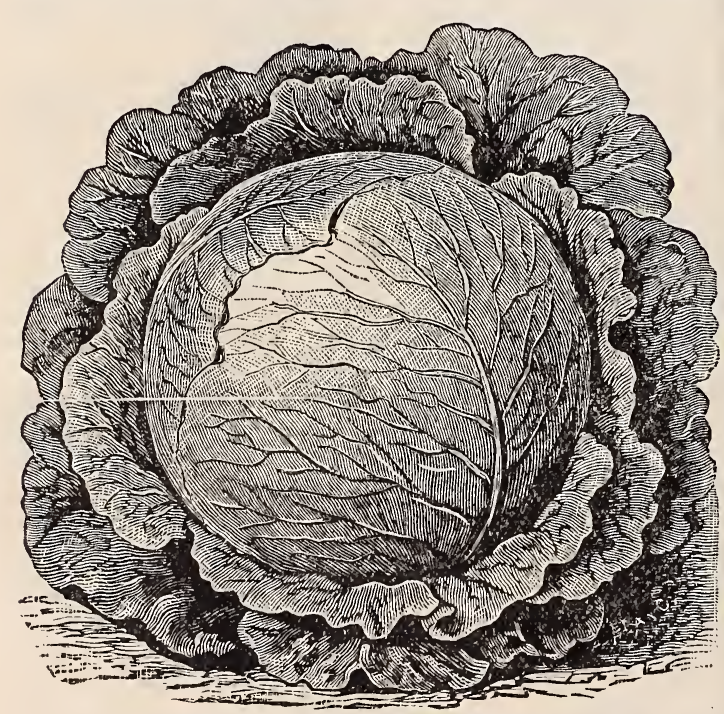

Cabbage-Danish Ball Head. varied climate than probably any other variety. Pkt., 5c; oz., 15c; 1/4 lb., 50c; $1 \mathrm{lb} ., \$ 1.50$.

MARBLEHEAD MAMMOTH DRUMHEAD.Late; the largest cabbage grown. Under high culture it is compact and hard, and of fairly good quality. Pkt., 5c; oz., $20 \mathrm{c} ; 1 / 4 \mathrm{lb} ., 60 \mathrm{c} ; 1$ lb., $\$ 2.00$.

DRUMHEAD SAVOY.-The finest flavored of all the cabbage family; large and solid; used extensively in the markets of Europe, but not so well known in this country. Pkt., $5 \mathrm{c}$; oz., $20 \mathrm{c} ; 1 / 4 \mathrm{lb} ., 60 \mathrm{c}$; per $1 \mathrm{~b} ., \$ 2.00$.

EXTRA EARLY RED ERFURT.-An early sort, make good head of excellent quality. Pkt., $5 \mathrm{c}$; oz., $20 \mathrm{c}$; $1 / 4 \mathrm{lb}$., $60 \mathrm{c}$; per lb., $\$ 2.00$.

MAMMOTH ROCK RED.-This is the best, largest and surest heading red cabbage ever introduced. Heads deep red to the center, and will frequently average twelve inches. A sure cropper, and in every way a first-class sort. Pkt., 5c; oz., 25c; 1/4 lb., 75c; 1 lb., $\$ 2.25$. 
If by mail, postage must be added at the rate of 8 cents per pound. On packets, ounces and quarter pounds, postage free.

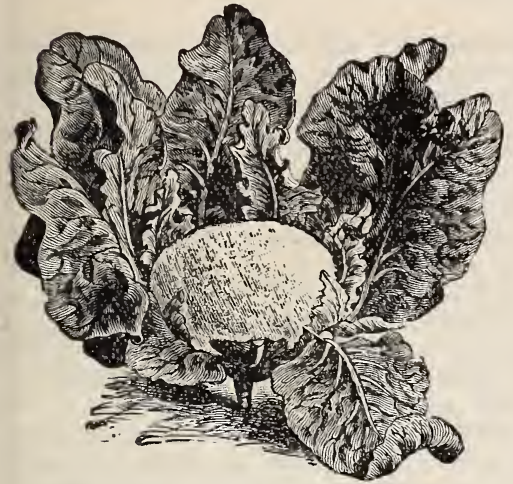

Cauliflower-Danish Snowball.

\title{
CAULIFLOWER.
}

\author{
Chou-Fleur-Coliflor-Blumenkohl.
}

Culture.-The same as for Cabbage, except that extra manure and plenty of water will pay upon Cauliflower. If the soil be dry, water frequently, and if the plants could have a heavy mulch of hay or straw, it would keep the soil moist, and the plants would not suffer from a drouth. The early kinds should be strong enough to plant out not later than the middle of April; the late kinds may be planted out same time as Cabbage. To destroy the Cauliflower maggot, it is recommended to take one ounce of sulphuret of potassium and dissolve it in one gallon of water. Heat the liquid to about 100 degrees, take a large spoon, or something that will hold the one hundredth part of a gallon, and pour the liquid against the stalk of the plant just above the ground. One ounce produces 1,500 good plants.

EARLY PARIS.-A most excellent French variety, and the popular early sort in the Paris markets. Heads large, white, compact and solid; of excellent flavor, tender and delicious. Per pkt., 5c; 1/4 oz., 25c; 1/2 oz., 40c; per oz., $75 \mathrm{c} ;$ per $1 / 4$ lb., $\$ 2.00$.

EARLY DWARF ERFURT.-The Erfurt strains of Cauliflower are most popular with market gardeners, being of dwarf growth, early and sure-heading habit. While less expensive than our choicest strains, this will be found to give very good results. Pkt., 10c; 1/4 0z., 35c; 1/2 oz., 60c; per oz., $\$ 1.00$; per $1 / 4$ lb., $\$ 3.50$.

EXTRA EARLY SELECTED DWARF ERFURT.-This is the choicest selected strain of the popular Erfurt type, and is remarkable for its extreme reliability in heading. Plant very dwarf with solid pure white head, of superior quality. The seed of this Cauliflower was saved with the greatest care, and only from perfectly developed heads, and it is considered to be the perfection of all Cauliflowers. Per pkt., $15 \mathrm{c} ; 1 / 4$ Oz., $75 \mathrm{c}$; $1 / 2$ Oz., $\$ 1.50$; per oz., $\$ 2.50 ;$ per $1 / 4$ lb., $\$ 8.00$.

EARLY DANISH SNOWBALL.-This variety, by innumerable trials, has established the claims made for it. The plants are very dwarf. The outer leaves are erect; the inner ones lap over the head so as to completely shade from the sun. We think it is equal to the Henderson's Early Snowball sold in the Denver market for many years. Through many seasons it has proved itself reliable, and gardeners can trust it every time. Per pkt., $15 \mathrm{c} ; 1 / 4$ oz., $75 \mathrm{c} ; 1 / 2$ oz., $\$ 1.50 ; 0 z ., \$ 2.50 ; 1 / 41 b$. $\$ 8.00$.

LENORMAND'S SHORT STEM.-Considered one of the very best sorts for late crop. Plant hardy, compact-growing, sure-heading, and producing many leaves which protect the close, solid curd, keeping it well-blanched. Pkt., 10c; $1 / 4$ oz., $25 \mathrm{c} ; 1 / 2$ oz., $40 \mathrm{c} ;$ oz., $75 \mathrm{c} ; 1 / 4$ lb., $\$ 2.00$.

\section{CARROTS. \\ Carotte-Zanahoria-Mohr-Rube.}

The carrot, like other root crops, delights in a sandy loam, deeply tilled. For good crops, sow in spring, as soon as the ground is in good working order; for late crops they may be sown any time until the middle of June. Sow in rows, about fifteen inches apart, thinning out to three inches between the plants. One ounce to one hundred feet of drill; three to four lbs. to an acre.

EXTRA EARLY FRENCH FORCING.-The earliest variety. Valuable for forcing. Root is small and round. Quality is excellent. This sort is highly prized in France. Plkt., 5c; oz., 10c; 1/4 lb., 30c; 1 lb., $\$ 1.00$.

EARLY SCARLET HORN.-A very early variety; good for home use. Texture fine; very delicate in flavor; Eastern market gardeners use this sort for bunching. Pkt., $5 \mathrm{c}$; oz., 10c; $1 / 4$ lb., $25 \mathrm{c} ; 1 \mathrm{lb} ., 75 \mathrm{c}$.

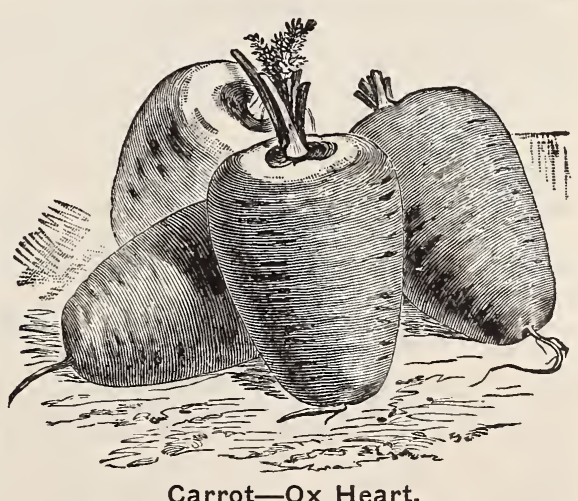

OX HEART OR GUERANDE.-This new French carrot is one of the most valuable of all recent introduction, either for family use or market. It is an intermediate between the half-long and horn varieties, attaining a diameter of three or four inches at the neck and of most beautiful shape and rich, orange color. It is of extra quality, and very productive. Pkt., 5c; oz., 10c; 1/4 lb., $25 \mathrm{c} ; 11 \mathrm{~b}$., $75 \mathrm{c}$.

CHANTENAY.-One of the most perfect and uniform in shape; smooth, heavy yielder, and of fine table qualities. It grows five or six inches long; is fine in texture and easily dug; color deep orange red; flesh very crisp and tender and is undoubtedly one of the best for both the market and private garden. Pkt., $5 \mathrm{c} ;$ oz., $10 \mathrm{c} ; 1 / 4$ lb., $25 \mathrm{c} ; 1 \mathrm{lb} ., 75 \mathrm{c}$. 
If by mail, postage must be added at the rate of 8 cents per pound.

On packets, ounces and quarter pounds, postage free.

\section{CARROTS-Continued.}

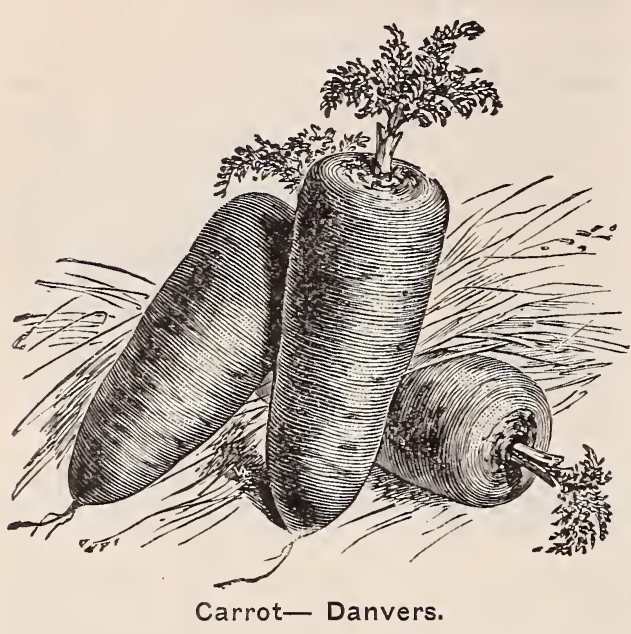

HALF-LONG SCARLET NANTES.-Tops medium size; roots cylindrical, smooth, bright orange; flesh, orange, becoming yellow in center, but with no distinct core; of the finest quality, and one of the most symmetrical and handsome of the medium-sized sorts; excellent for the market or home garden. Pkt., 5c; oz., $10 \mathrm{c} ; 1 / 4$ lb., $25 \mathrm{c}$; 1 lb., $75 \mathrm{c}$.

DANVERS.-This a broad-shouldered carrot, cylindrical in shape, stump rooted; of excellent color; best flavor, and a most wonderful producer. This is a popular field variety, and although the roots are shorter they produce as large a bulk as the longer field sorts, and are more easily harvested. Pkt., 5c; oz., $10 \mathrm{c} ; 1 / 4$ Oz., $25 \mathrm{c} ; 1 \mathrm{lb} ., 75 \mathrm{c}$.

IMPROVED LONG ORANGE.-A well-known sort; roots long, thicker near the crown, tapering regularly to a point; color, deep orange. It is a good keeper; of fine quality; for winter use, and extensively grown for stock-feeding. Plkt., 5c; oz., 10c; 1/4 lb., 25c; $1 \mathrm{lb} ., 75 \mathrm{c}$.

LARGE WHITE BELGIAN.-Grows one-third out of the ground; root, pure white, green above ground, with small top. The roots on light, rich ground grow to a large size, and are extensively grown for stock-feeding. Pkt., 5c; oz., 10c; $1 / 41 \mathrm{~b} ., 20 \mathrm{c} ; 1 \mathrm{lb}$., $60 \mathrm{c}$ LARGE YELLOW BELGIAN.-Same as above, except in color. Pkt., 5c; oz., 10c; 1/1 1b. 20c; 1 1b., $60 \mathrm{c}$.

\section{CELERY.}

Celeri-Apio-Selleri.

Plant seed in hot-bed. Transplant four inches apart when three inches high, in rich soil finely pulverized; water and protect until well rooted, then transplant into rows five or six feet apart, either on surface or in well-manured trenches a foot in depth, half filled with well-rotted manure. Set the plants from eight to twelve inches apart. To blanch, draw earth around the plants from time to time, taking care not to cover the tops of the center shoots. One ounce will produce 3,500 good plants.

GOLDEN SELF-BLANCHING.-This variety is now the leading sort in all markets as an early celery. The plant is of beautiful appearance, of close habit; compact growth, and straight, vigorous stalks. The ribs are perfectly solid, crisp, brittle and of fine flavor. The best self-blanching sort. It acquires a handsome, golden color without having to be hilled up. Our stock comes direct from France from the originator, and can be relied upon as the best in the market. Pkt., 5c; $1 / 2$ oz., $20 \mathrm{c}$; oz., $35 \mathrm{c}$; $1 / 4$ lb., $\$ 1.25$; per lb., $\$ 4.00$.

GOLDEN SELF-BLANCHING. - Best American grown. Plkt., 5c; $1 / 2$ Oz., $15 \mathrm{c}$; per oz., $25 \mathrm{c}$; per $1 / 4$ 1b., $75 \mathrm{c}$; per 1b., $\$ 2.50$.

GIANT PASCAL.-One of the best for fall and winter use. It is a selection from the Golden Self-Blanching, and adds to the general good qualities. The stalks are very large, solid, crisp, and of a rich nutty flavor; it blanches very easily and quickly. The heart is golden yellow; very attractive. Pkt., 5c; oz., 20c; $1 / 4$ lb., 60c; per lb., $\$ 1.50$.

ROSE-RIBBED PARIS SELF-BLANCHING.-This fine celery has given the greatest satisfaction where tried. It is decidedly a great acquisition, being a rosy red form of the golden variety; very solid, large and early, while the flavor is far superior to any white celery yet produced. Per oz., $30 \mathrm{c} ; 1 / 4 \mathrm{lb}$., $\$ 1.00 ; 1 \mathrm{lb}$, $\$ 3.00$.

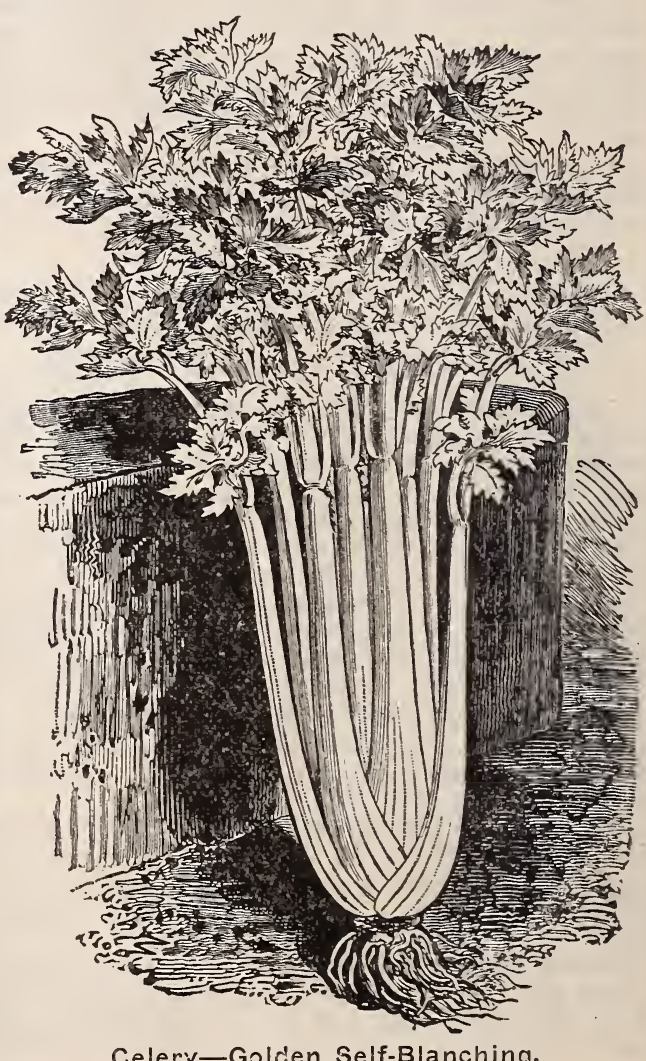


If by mail, postage must be added at the rate of 8 cents per pound.

On packets, ounces and quarter pounds, postage free.

\section{CELERY - Continued.}

WHITE PLUME.-A good self-blanching sort, good for fall use, but does not keep well. Pkt., 5c; oz., $20 \mathrm{c}$; $1 / 4$ lb., $60 \mathrm{c}$; per lb., $\$ 2.00$.

GOLDEN DWARF.-A very popular and distinct variety. In habit of growth it resembles the Half Dwarf, except that when blanched the heart, which is large and full is of waxy golden yellow. Pkt., $5 \mathrm{c}$; oz., 15c; $1 / 4$ lb., $50 \mathrm{c} ; 1 \mathrm{lb} ., \$ 1.50$.

BOSTON MARKET.-It forms a cluster of heads instead of a single one, and is remarkably tender and crisp. The most popular sort in the market of Boston. Pkt., 5c; oz., 15c; $1 / 41 \mathrm{~b} ., 50 \mathrm{c} ; 1 \mathrm{lb}$., $\$ 1.50$.

CELERIAC OR TURNIP-ROOTED-LARGE PRAGUE.-Has a large, smooth root, and is the finest of all Celeriac. Pkt., 5c; oz., $20 \mathrm{c} ; 1 / 4 \mathrm{lb} ., 50 \mathrm{c}$.

\section{CORN SALAD.}

\section{Mache-Rabinschen Feldsalat.}

BROAD LEAVED.-Used as a small salad throughout the winter and spring. Sow thickly in drills; cover slightly first of autumn anu sprinkle with straw on the approach of bad weather, or sow in a cold frame, covered in winter as may be convenient, thus it is accessible, even when deep snow prevails. Pkt., 5c; oz., 10c; $1 / 4 \mathrm{lb} ., 25 \mathrm{c} ; 1 \mathrm{lb} ., 75 \mathrm{c}$.

\section{SWEET CORN.}

Mais-Maiz Para el uso de la Mesa-Welsch-Korn fur Tischgebrauch.

(Add 8c per lb. for Postage.)

All varieties of sweet corn may be either sown in rows, four and a half feet apart, and the seeds planted about eight inches in the row, or planted in hills at a distance of three or four feet each way, according to the variety grown or the richness of the soil in which it is planted. One pound to one hundred hills. Ten pounds to an acre.

Prices for all varieties: Pkt., 5c; 1/2 lb., 10c; 1 lb., 15c; 2 lbs., 25c; 10 lbs. for $\$ 1.00$. If sent by mail, postage must be added at rate of $8 \mathrm{c}$ per pound.

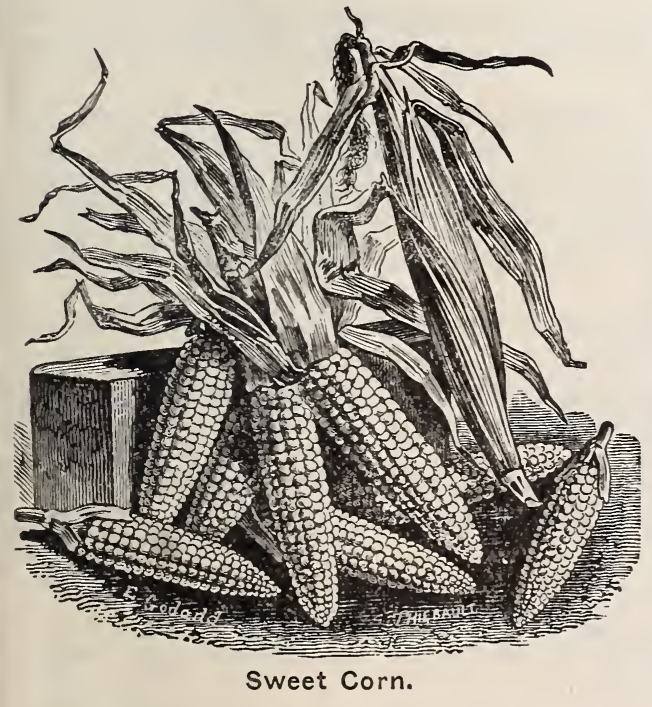

CORY, WHITE COB.-It is without doubt one of the earliest corns known. The ear is as large as Red Cory, or larger, and this with the few days gained in maturing, may give the market gardener double the price of that coming a little later.

EXTRA EARLY ADAMS.-One of the earliest, maturing for table in sixty days after germination. Height of stalk, three feet; not a sugar corn, but a decided acquisition-so very early in the season.

EARLY MINNESOTA.-This is among the earliest of the sugar varieties, and is much esteemed, not only because it matures so early, but for its excellent qualities as well.

MOORE'S EARLY CONCORD.-Ears large and well-filled; early and unsurpassed for richness and delicacy of flavor.

PERRY'S HYBRID.-A very fine early variety, full as early as the Minnesota, and ears much larger, each containing twelve to fourteen rows of kernels, well filled to the end. The grains are very large and pure white, but the cob is reddish.

CROSBY'S EARLY.-Most excellent variety and remarkably early. Ears of large size, medium length; sweet, rich and delicate.

COUNTRY GENTLEMAN.-This is tne finest of the medium early varieties. The rows are zig-zag, with a long, slender kernel of delicious flavor. This corn is bound to sell when properly known, as its quality is the best of all. 
If by mail, postage must be added at the rate of 8 cents per pound.

On packets, ounces and quarter pounds, postage free.

\section{SWEET CORN-Continued.}

MAMMOTH WHITE CORY.-The largest and best extra early sweet corn. The ears are twelverowed, fully twice the size of the old Cory; white cobbed and covered with very large, white grains of good quality, a great acquisition to the sweet corn family.

STOWELL'S EVERGREEN OR MAMMOTH.-This variety is more largely planted than any other, being the general favorite with canners and market gardeners for late use. It is very productive; the ears are of a large size; grains deep; exceptionally tender. It remains in condition for use longer than other sorts.

EGYPTIAN SWEET.-One of the best late varieties, and certainly the handsomest of all the late sorts; ears large, none more uniform, and excels all in filling out perfectly at the tip end. Very productive, and used extensively for market and canning.

\section{SELECTED FIELD CORN SEED.}

Liberal packets, 5c; pound, 10c; 3-pound package, 25c; 10 pounds, $50 \mathrm{c}$.

(Postage at rate of $8 \mathrm{c}$ per pound must be added if sent by mail.)

SWADLEY FIELD CORN.-Nearly as hardy as White Australian, and fully as early, and yields more matured corn. This is the true Swadley Field Corn which was originally brought to Jefferson County, Colorado, from the mountain farms of Virginia, nineteen years ago, by Mr. Geo. C. Swadley. He has cultivated it ever since and has supplied the market for several seasons, though never having enough to fill all orders. We are firmly convinced that it is the corn for uplands and worn-out soils, where it produces 35 to 50 bushels of ears per acre. It stands drouth nearly as well as White Australian. It is much softer kernel, being a pale yellow dent. The ears will average eight inches long, twelve to sixteen-rowed. One-third of the crop will yield two ears on a stalk, maturing in ninety to one hundred days. Six pounds of seed will plant an acre, three feet, eight-inch, check-rows. This is the corn for our short-season districts. Give it a trial, you will be well pleased.

AUSTRALIAN WHITE FLINT.-The earliest and surest variety we have for Colorado and the arid lands of the west. It will actually endure more drouth and cold than any other variety known. Grows to a height of six to ten feet, ears varying from eight to twelve inches long, usually eight or ten-rowed, one and two ears on a stalk.

COLORADO YELLOW DENT.-An early Dent variety; ripening with the Flint varieties, and can be grown in almost any locality. Stalks large, with broad leaves; ears eight to ten inches; sixteen rowed; grain yellow; making a good quality of meal.

PRIDE OF THE NORTH (90 days).-This variety has smaller ears than late kinds, but is valuable to grow as it matures earlier. Planted as late as July 4, it has fully matured by October 1. The ears have from fourteen to sixteen rows, grown eight to ten inches in length, slightly tapering. The kernels are closely set together on the cob, of a light orange color. The stalks usually grow six to eight feet in height, producing one or two good ears. Our seed of this variety has been grown for us with special care, from the original stock.

IMPROVED LEAMING (90 days).-This is one of the earliest large, yellow Dent Corns in cultivation, ripening in 90 to 100 days from planting. It is extra early, and not a hard flinty corn. The ears are large and handsome, with deep, large grains; orange yellow color and red cob. Stalks medium size, tapering gradually, producing two good ears each; husks and shells very easily.

\section{POP CORN OR PARCHING.}

(Postage, 8c per lb., extra.)

WHITE PEARL.-Our common market variety. Pkt., 5c; 1 lb., 15c; 2 lbs. for $25 \mathrm{c}$.

WHITE RICE.-A very handsome variety; kernels long, pointed, and resembling rice; color, white; very prolific. Pkt., 5c; $1 \mathrm{lb} ., 15 \mathrm{c} ; 2 \mathrm{lbs}$. for $25 \mathrm{c}$.

QUEEN'S GOLDEN.-The stalks grow six feet high, and the large ears are produced in abundance. It pops perfectly white, and a single kernel will expand to a diameter of one inch. Pkt., 5c; $1 \mathrm{lb} ., 15 \mathrm{c} ; 2 \mathrm{lbs}$. for $25 \mathrm{c}$. 
If by mail, postage must be added at the rate of 8 cents per pound.

On packets, ounces and quarter pounds, postage free.

\title{
CUCUMBERS.
}

\author{
Concombre-Pepino-Gurke.
}

Drop in hills four to six feet apart, as soon as the weather becomes settled and warm. Scatter eight or ten seeds to a hill and cover half an inch deep, and pat it down with a hoe. Hoe often, and when out of danger of insects, thin to four plants to a hill. June to July is the time to sow for pickling. One ounce to 50 hills; two to three pounds to an acre.

Cucumbers seeds are very scarce this year and consequently high. Crop almost a failure.

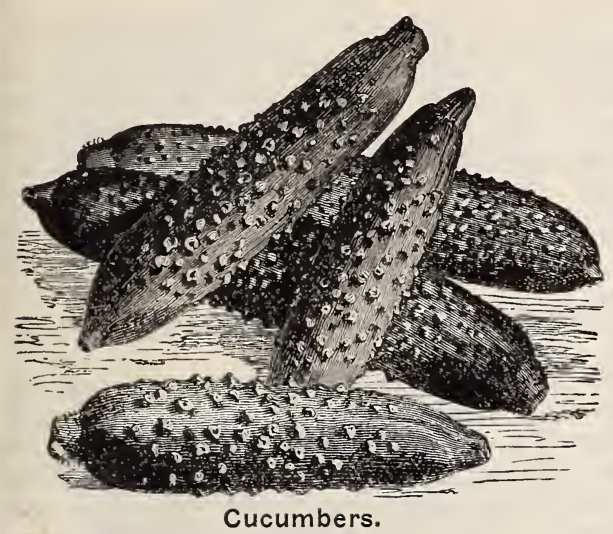

EXTRA LONG WHITE SPINE.-A selected strain of the White Spine. Is very uniform in size and exceedingly early, at the same time makes long growth -10 to 12 inches. The variety for forcing and early market. Pkt., 5c; oz., 20c; $1 / 4$ lb., 60c; 1 lb., $\$ 2.25$.

SHORT GREEN OR FRAME.-Excellent for table use, being tender and well flavored; hard, green pickles, Pkt., 5c; oz., 20c; 1/4 lb., 60c; 1 lb., $\$ 2.00$.

GREEN PROLIFIC OR BOSTON PICKLING.-A distinct variety. A favorite with pickle growers; medium long; a great producer. Pkt., 5c; oz., 20c; 1/4 lb., 60; 1 lb., $\$ 2.00$.

NICHOL'S MEDIUM GREEN.-This new variety is excellent as pickle sort, and for forcing purposes there is no better variety. It is very productive; of medium size, and always straight and smooth; color, dark green; fiesh crisp and tender. Pkt., 5c; oz., 20c; 1/4 lb., 60c; 1 lb., $\$ 2.00$.

IMPROVED LONG GREEN.-This is unquestionably the most popular general purpose cucumber in the west; fruit long and slim; not surpassed in quality by any variety. Pkt., $5 \mathrm{c} ; 0 \mathrm{oz}, 20 \mathrm{c} ; 1 / 4 \mathrm{lb} ., 60 \mathrm{c} ; 1 \mathrm{lb} ., \$ 2.00$.

\section{CRESS OR PEPPER=GRASS.}

Cresson-Mastuerzo-Ojaertun-Kresse.

Plant on rich soil, finely pulverized, in drills six or eight inches apart. To be used as salad before the flowers appear.

GARDEN CRESS, CURLED.-Per pkt., $5 \mathrm{c} ;$ oz., $10 \mathrm{c} ; \mathrm{r} / 4 \mathrm{lb} ., 15 \mathrm{c} ; 1 \mathrm{lb} ., 50 \mathrm{c}$.

\section{CRESS-TRUE WATER.}

Is quite distinct from the common, and only thrives when its roots and stems are submerged in water. It is one of the most delicious of small salads, and should be planted wherever a suitable place can be found. Pkt., 5c; oz., $35 \mathrm{c} ; 1 / 4 \mathrm{Ib} ., \$ 1.25$.

\section{CHICORY.}

Pursue the same manner of cultivation as for carrots. If to be used as a salad, blanch the leaves by covering so as to exclude the light. If raised for its roots, dig at about the same time as carrots, wash the roots and then slice them, either way, and dry thoroughly by artificial heat.

LARGE-ROOTED.-(For C'offee.) Used as substitute for coffee. Per pkt., 5c; oz., 10c; I/4 lb., 30c.

IMPROVED VERY LARGE LEAVED.-An improved variety, with large leaves. Per pkt., 5c; oz., $15 \mathrm{c} ; \mathrm{I} / 4 \mathrm{lb} ., 50 \mathrm{c}$.

\section{DANDELION.}

\author{
Pissenlit-Loewenzahn.
}

Cultivated for greens and used as spinach or salad. One ounce to 250 feet of drill. COMMON.-Per pkt., $5 \mathrm{c}$; oz., $20 \mathrm{c} ; \mathrm{I} / 4 \mathrm{lb} ., 50 \mathrm{c}$. 
If by mail, postage must be added at the rate of 8 cents per pound.

On packets, ounces and quarter pounds, postage free.

\section{EGG PLANT.}

\section{Aubergine-Berengena-Hierflanze.}

Sow in hot-beds very early in the spring, and transplant to two or three feet apart in very rich, warm ground. Hoe often and hill up gradually till they blossom. One ounce to 1,500 plants.

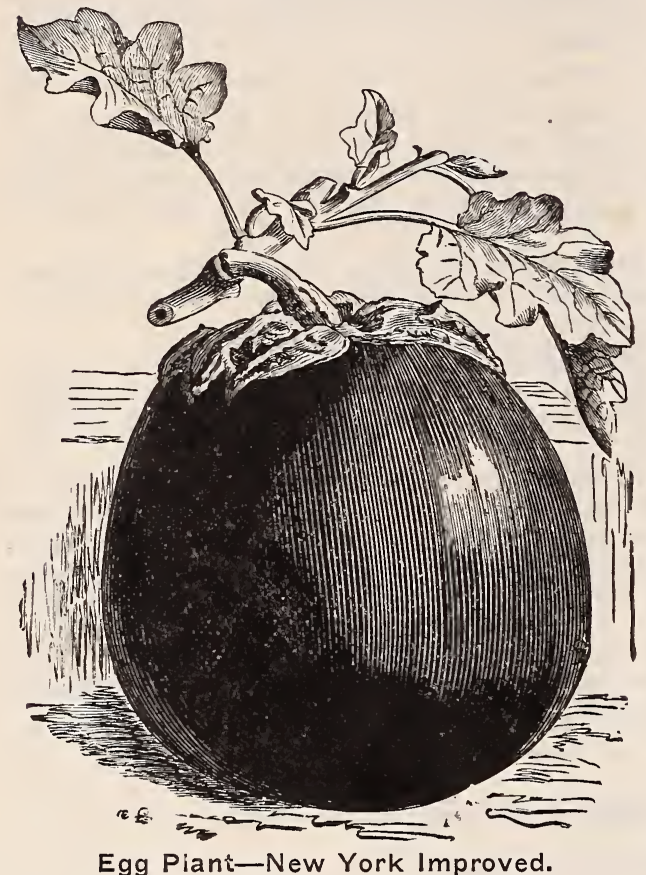

EARLY LONG PURPLE.-This is the earliest variety; very hardy and productive; fruit long and of superior quality. Pkt., 5c; $1 / 4$ oz., 10c; oz., 25c; $1 / 4$ 1b., $75 \mathrm{c}$.

NEW YORK IMPROVED-LARGE, PURPLE, SPINELESS.-This variety has about superseded all others both for market and home garden; a favorite in Colorado. Our stock is extra selected direct from the best growers. Pkt., 5c; $1 / 4$ oz., 15c; oz., 40c; $1 / 4$ lb., $\$ 1.25$.

\section{ENDIVE.}

Chicoree-Endive-Escarola o Endivie-EndivienSalat.

For early use sow as soon as the ground can be worked in the spring, in drills fifteen inches apart, and thin plants to six or eight inches in the row. To blanch the leaves, gather them carefully together when perfectly dry and tie with matting or any soft fibrous material. The leaves are very highly esteemed for use as salad. One ounce to 75 feet of drill.

GREEN CURLED WINTER.-A very popular winter variety; requires to be tied up for blanching. Pkt., 5c; oz., 15c; r/4 1b., 30c.

BROAD-LEAVED BATAVIAN, WINTER.-Very similar to the preceding, but used chiefly in the fall. Pkt., 5c; oz., 15c; 1/4 lb., 30c.

\section{KOHL=RABI, or Turnip=Rooted Cabbage.}

The Kohl-Rabi is a vegetable intermediate between the cabbage and turnip, and combines the flavor of each. The edible part is a turnip-shaped bulb, formed by the enlargement of the stem. When used for the table this should be cut when quite small, as it is then very tender and delicate, but if allowed to reach its full size it becomes tough and stringy.

EARLY WHITE VIENNA.-The earliest and best for forcing; very tender; excellent for table use. Pkt., 5c; oz., 20c; $1 / 41 b ., 60 c$.

EARLY PURPLE VIENNA.-Same as above, only differs in color. Pkt., 5c; Oz., 20c; $1 / 4$ lb., 60 .

\section{HORSE=RADISH.}

Horse-radish produces no seed, but is grown from pieces of the root.

Culture.-Mark off rows $2 \frac{1}{2}$ feet apart in rich, moist, well-prepared ground, and set the pieces of root eighteen inches apart in the rows, vertically, the small end down. Cultivate thoroughly until the tops cover the ground, when their shade will keep down the weeds. Small roots, 20c per dozen; 85c per 100, post paid.

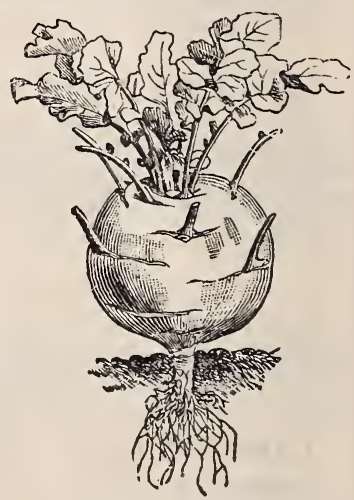

Vienna Kohl-Rabi.

\section{GARLIC.}

Garlic is the most pungent of all the onion family. It is much used in the south of Europe. The root or bulb is composed of many small bulbs called "cloves," which are planted in the spring six to eight inches apart, and in August the tops will die, when the bulbs are ready to gather. They do best in light, rich soil. Large bulbs, 1 lb., 30c; 3 lbs. for 80c; post paid. Small bulblets, 40c per lb., post paid. Write for prices on large lots. 
If by mail, postage must be added at the rate of 8 cents per pound.

On packets, ounces and quarter pounds, postage free.

\section{LETTUCE.}

Laitue-Lechuga-Salat.

The early sowing may be made under glass in February and March, keeping the plants thin and admitting plenty of air every fine day. For main early crop, seed may be sown in the open ground, middle of September, and transplanted to cold frames as soon as large enough to handle, being wintered over in the same manner as early cabbage. One ounce to 4,000 plants.

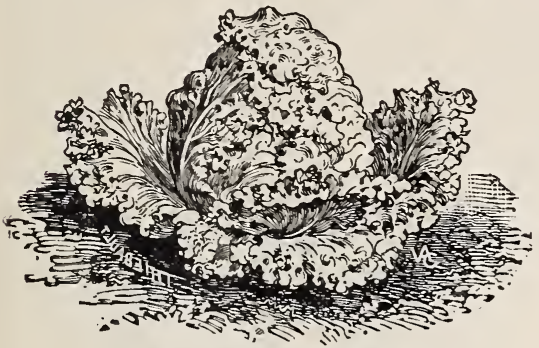

Lettuce-Cincinnati.

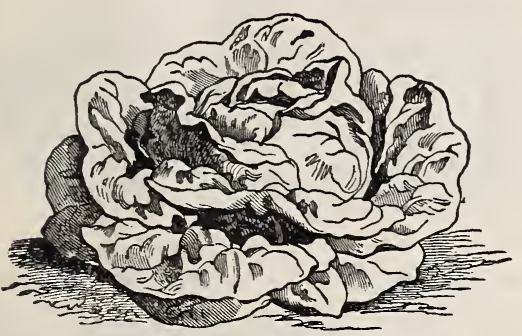

Lettuce-Silver Ball.

FORCING SORTS.

EARLY OHIO OR CINCINNATI.-A splendid lettuce, equally good for forcing or for summer use. This fine lettuce is very slow to run to seed, and in the open ground will make a large, solid light green head of the finest quality and flavor. This variety is much sought after by our leading market gardeners. Per oz., 10c; $1 / 4$ lb., 30c; 1 lb., $\$ 1.00$.

SIMPSON'S EARLY CURLED.-One of the best early sorts for market or family use. All the leaves tend to produce a large, loose head; leaves beautifully crimped, dark green, very tender and crisp; recommended for general culture. Pkt., 5c; oz., 10c; 1/4 lb., 30c; 1 lb., $\$ 1.00$.

BLACK-SEEDED SIMPSON.-This is one of the most popular in the Denver market. Forms large, loose heads. Leaves thin and exceedingly tender; of light green to golden yellow. Best sort for forcing or out-door early planting. Pkt., 5c; oz., 10c; $1 / 4$ lb., 30c; 1 lb., $\$ 1.00$.

DENVER MARKET. - It is an early variety of Head Lettuce, either for forcing or open ground. It forms large heads; of good light green color; and is very slow to go to seed; the leaves are beautifully marked and blistered (like the Savoy Cabbage); very crisp and tender; and of excellent flavor. Pkt., 5c; oz., 10c; $1 / 4$ lb., $30 \mathrm{c} ; 1 \mathrm{lb} ., \$ 1.00$.

GRAND RAPIDS.-As a lettuce for greenhouse forcing, this variety undoubtedly stands at the head of the list, being of quick growth, little liable to rot, and standing for some days after being fit to cut. Fine appearance and strong grower. Pkt., 5c; oz., 10c; 1/4 1b., 30c; 1 lb., $\$ 1.00$.

EARLY PRIZE HEAD.-It forms a mammoth head and remains tender and crisp throughout the season; is prompt to head, but slow to seed; of superior flavor and very hard. The leaves are very large, crimped, bright green, tinged with brownish red on edge. Pkt., 5c; oz., 10c; 1/4 lb., 30c; $1 \mathrm{lb}$., $\$ 1.00$.

HANSON.-The heads are of very large size, deliciously sweet, tender and crisp, even to the outer leaves; color, green outside and white within, and stands heat extraordinarily well. Not recommended for forcing, but has few superiors for family use. Pkt., 5c; oz., 10c; 1/4 lb., 30c; 1 lb., $\$ 1.00$.

SILVER BALL.-A remarkable variety in that it is an excellent sort both for forcing and outdoor culture. The thick, light green leaves have so much sheen that they actually look silvery white in some lights. The heads are of good size, and of excellent quality. Pkt., 5c; oz., 10c; 1/4 lb., $30 \mathrm{c} ; 1$ lb., $\$ 1.00$.

EARLY TENNISBALL.-The best variety of head or cabbage lettuce for growing under glass; very hardy; leaves thick, crisp and tender, forming under glass a compact head. Pkt., 5c; oz., 10c; $1 / 4$ lb., 30c; 1 lb., $\$ 1.00$.

PARIS WHITE COS.-The Cos Lettuces are distinct from the preceding sorts, in having long, narrow, spoon-shaped leaves, which usually fold into loose, sugar-loaf shaped heads, which blanch better by having the outer leaves drawn about them and tied. They have come into favor, and rightly so, for their crisp and tender leaves. Pkt., 5c; oz., 10c; 1/4 1b., $30 \mathrm{c} ; 1 \mathrm{lb} ., \$ 1.00$.

\section{LEEK.}

Poireau-Puerro-Lauch oder Porre.

A hardy species of onion, sown in drills or broad-cast. When six inches high transplant into rows a foot apart, setting the plants four or five inches deep, and about six inches apart in the row. Used mostly in soups and stews. One ounce to 1,000 plants.

LARGE AMERICAN FLAG.-This leek, aside from being valuable for soups and salads, when blanched, makes an excellent dish when sliced and cooked like green peas. Pkt., 5c; oz., 15c; 1/4 lb., 50c; 1 lb., $\$ 1.50$. 
If by mail, postage must be added at the rate of 8 cents per pound.

On packets, ounces and quarter pounds, postage free.

\section{MUSHROOM SPAWN.}

Mushrooms may be cultivated much easier than is generally supposed. They may be grown in a cellar or shed or in beds prepared in the open air, in the same manner as hot-beds. Take fresh

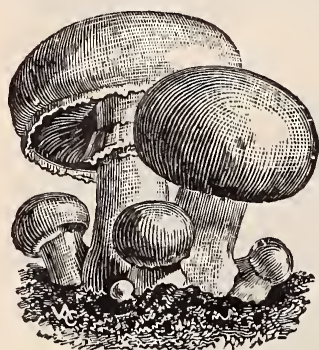

Mushroom. horse manure, shake it well apart, and lay it into a heap to ferment. Turn and mix it well every three or four days, by shaking together the outside of the heap, which is cold, and the inside, which is hot, so that every part of it may be equally fermented and deprived of its noxious quality. When the dung is in a fit state to be made into a dry spot for a foundation, mark out the bed, which should be four feet wide and as long as you choose to make it. In making the bed, mix the dung well together, beating it down with the fork until eighteen or twenty inches thick. In this state it may remain until the temperature is about 74 degrees. Divide the large cakes of spawn into small lumps, plant two inches below the surface, six inches apart, cover with two inches of fine, light soil and press down evenly and protect from heavy rains. The mushrooms will make their appearance in from four to six weeks, accorling to the season. After the bed has been spawned, do not water unless quite dry; use lukewarm water only. Per brick, 25c; 5 lbs., $\$ 1.00$, post paid. If wanting quantity, write for prices.

\section{MARTYNIA, or Unicorn Plant.}

A strong-growing hardy annual plant with curious shaped seed pods, which, when young and tender, are highly prized for pickling. The pods are produced in great abundance, and should be gathered when less than half grown. Pkt., 5c; oz., 25c; 1/4 lb., 75c; 1 lb., $\$ 2.50$.

\section{MUSTARD.}

\section{Moutarde-Mostaza-Senf.}

Mustard is not only used as a condiment, but the green leaves are used as a salad, or cut and boiled like spinach.

GIANT SOUTHERN CURLED.-The large leaves, which often measure fourteen inches, are ready for use in about six weeks after sowing. Plant will continue to yield until frosty weather. Leaves are eaten, boiled like spinach. Pkt., 5c; oz., 10c; 1/4 lb., 30c; 1 lb., $\$ 1.00$.

WHITE ENGLISH.-Best for salads and medicinal purposes. Oz., 5c; 1/4 1b., 15c; 1 lb., 30c.

\section{MELON-MUSK.}

\section{Melon Cantaloup-Melon Muscatel-Melonen Cantaloupen.}

Melons thrive best in a moderately enriched, light soil; the hills should be six feet apart each way. Previous to planting, incorporate well with the soil in the hill a couple of shovelfuls of thoroughly rotted manure; plant twelve or sixteen seeds in each hill, early in May, and when well up, thin out to three or four of the most promising. Pinch off the leading shoots as the growth becomes too luxuriant, and if the fruits set too numerously thin out when young, which will increase the size of those remaining, and cause them to ripen quicker. One ounce to 60 hills; two to three pounds to an acre.

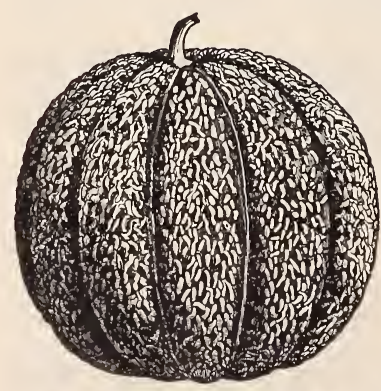

Musk Melon-Extra Early Cantaloupe.

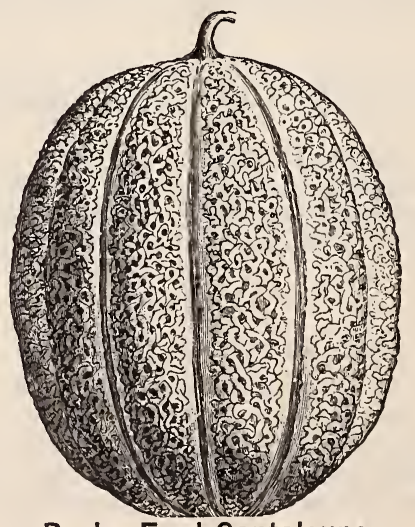

Rocky Ford Cantaloupe.

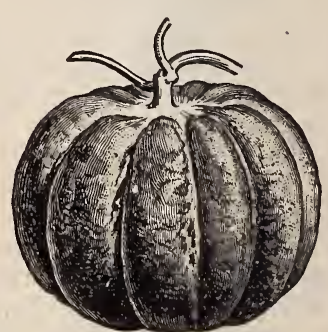

Musk Melon-Emerald Gem. 
If by mail, postage must be added at the rate of 8 cents per pound.

On packets, ounces and quarter pounds, postage free.

\section{MELON-MUSK-Continued}

THE ROCKY FORD MELON is a new and most valuable introduction, and has attained in an incredibly short time a national reputation. It is of the Netted Gem type, oval in shape, averaging from four and one-half to five inches in length; of a delicious flavor; very fine and smooth-grained flesh, of a light green color throughout when ripe. Pkt., 5c; oz., 10c; I/4 lb., 30c; 1 lb., $\$ 1.00$.

EARLY YELLOW CANTALOUPE.-One of the earliest varieties; of good size; nearly round; slightly ribbed; flesh yellow. Pkt. 5c; oz., 10c; 1/4 lb. 30c; $1 \mathrm{lb} ., \$ 1.00$.

EXTRA EARLY CITRON.-Very early, large, showy and of good flavor. A variety which, for its early maturity, will be found profitable by all market gardeners. Pkt., 5c; oz., $10 \mathrm{c} ; 1 / 4 \mathrm{lb}$., $30 \mathrm{c}$; $1 \mathrm{lb} ., \$ 1.00$.

GREEN NUTMEG.-Fruit nutmeg shape; skin deep green; finely netted; flesh greenish yellow; rich and sugary. Pkt., 5c; oz., $10 \mathrm{c} ; 1 / 4$ lb., 30c; 1 lb., $\$ 1.00$.

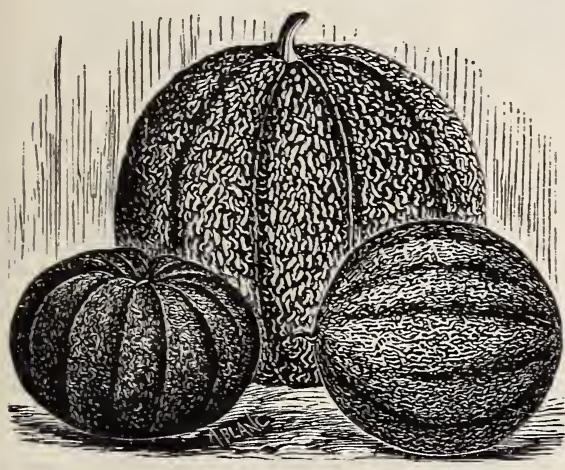

Extra Early Citron, Hackensack and Osage.

GOLDEN NETTED GEM.-One of the earliest, and no doubt, one of the best small melons grown. They are globular in shape, very uniform in size and weight, weighing from one and a quarter to one and a half pounds each; flesh light green and of very fine flavor. Pkt., 5c; oz., 10c; 1/4 lb., 30c; 1 lb., $\$ 1.00$.

HACKENSACK.-The most popular variety of Musk Melon grown for market by gardeners. It attains a large size; is round in shape, flattened at the ends; is of the most delicious flavor and wonderfully productive. Pkt., 5c; oz., $10 \mathrm{c} ; 1 / 4 \mathrm{lb} ., 40 \mathrm{c} ; 1 \mathrm{lb} ., \$ 1.25$.

GREEN FLESH OSAGE.-It is superior to any green-fleshed melon now known. It partakes of the many characteristics of yellow-fleshed Osage, but is more netted, while its flesh is a beau-

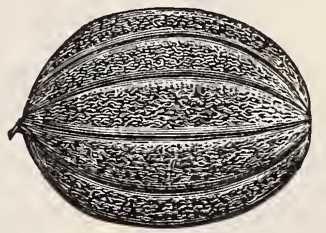

Golden Netted Gem.

tiful pea-green and of the most delicious quality. Pkt., 5c; oz., $10 \mathrm{c} ; 1 / 4 \mathrm{lb} ., 40 \mathrm{c} ; 1 \mathrm{lb}$., $\$ 1.25$.

EMERALD GEM.-Fruit small to medium-sized, globular, or slightly flattened at the ends; only slightly netted and ribbed; skin deep green while young, becoming tinged with yellow as the fruit matures; flesh deep salmon yellow, thick, ripening close to the rind, and exceedingly high flavored. Pkt., 5c; oz. 10c; $1 / 4$ lb., 40c; 1 lb., $\$ 1.25$.

OSAGE OR MILLER'S CREAM.-A remarkably fine variety, and a very profitable sort for market gardeners. It is of medium size; oval in form; dark green in color; handsomely netted and slightly ribbed. The flesh is extremely and uniformly thick; of firm texture; rich salmon in color. Pkt., 5c; oz., 10c; 1/4 lb., 40c; 1 lb., $\$ 1.25$.

MONTREAL MARKET.-The fruit is of the largest size, specimens often weighing twenty pounds and upwards; flesh very thick and of the finest flavor. Pkt., 5c; oz., 10c; 1/4 lb., $40 \mathrm{c} ; 1 \mathrm{lb} ., \$ 1.25$.

\section{MELON-WATER.}

\section{Melon d'Eau-Zandia-Wassermelonen.}

Drop middle of spring, in hills six to eight feet apart, six to ten seeds, one inch deep, and thin to three best plants. Hoe often, and gradually hill up until the vines touch, and after the fruit appears cut off the extreme ends of the most luxuriant shoots. One ounce to 50 hills; two to three pounds to an acre.

PHINNEY'S EARLY.-Flesh deep red; of very superior quality; early and productive; a very valuable market variety. Pkt., 5c; oz., 10c; 1/4 1b., 25c; $1 \mathrm{lb} ., 75 \mathrm{c}$.

COLE'S EARLY.-Is very early and will mature in every state. Melons are of medium size; nearly round in shape; rind green, striped with light. Pkt., 5c; oz., 10c; 1/4 1b., 25c; 1 lb., $75 \mathrm{c}$.

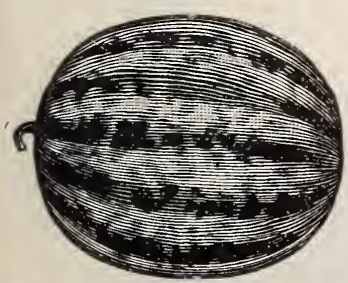

Water Melon-Kolb's Gem. MOUNTAIN SWEET.-Fruit of large size and oval in shape; flesh scarlet and quite solid; very sweet and delicious; best for general use. Pkt., 5c; Oz., 10c; 1/4 lb., 25c; 1 lb., $75 \mathrm{c}$.

ROCKY FORD.-This melon, as indicated by its name, was originated at Rocky Ford, Colo. It is well known to be the best shipping melon grown, whilst its flavor is far superior to any other melon grown. Per oz., 10c; 1/4 lb., 25c; 1 lb., $75 \mathrm{c}$.

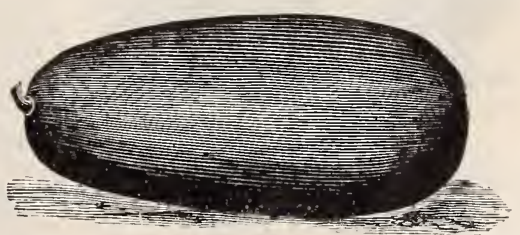

Water Melon-Ice Cream. 
If by mail, postage must be added at the rate of 8 cents per pound.

On packets, ounces and quarter pounds, postage free.

\section{MELON-WATER-Continued.}

ICE CREAM OR PEERLESS.-Form oblong; seeds white; flesh solid and of fine scarlet color; crisp and delicious; very popular in Colorado. Pkt., 5c; oz., $10 \mathrm{c} ; 1 / 4 \mathrm{lb} ., 25 \mathrm{c} ; 1 \mathrm{lb} ., 75 \mathrm{c}$.

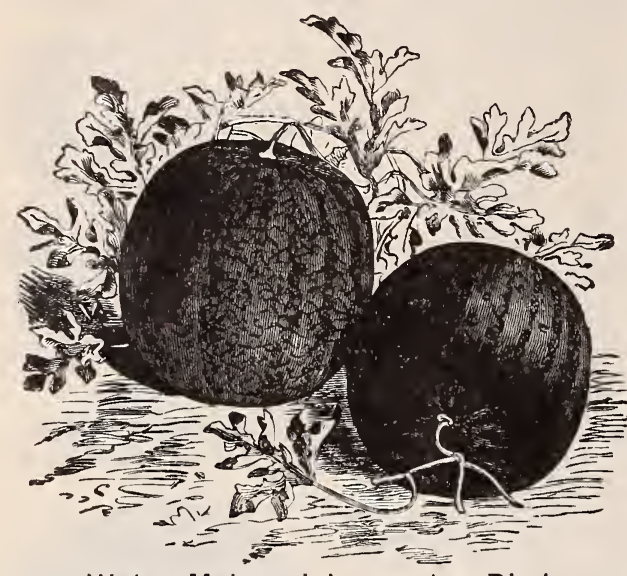

Water Melon-lcing or Ice Rind.

ICING OR ICE RIND.-One of the best of all melons; solid, always of good flavor; rind very thin; unexcelled in all good qualities; fruit of medium size; nearly round. Pkt., 5c; oz., 10c; $1 / 4$ lb., 25c; $1 \mathrm{lb} ., 75 \mathrm{c}$.

SWEET HEART.-This new melon is early, large, handsome, heavy and productive. The shape is oval, and color mottled light to very light green. Flesh bright red; solid, but tender and very sweet. Pkt., $5 \mathrm{c}$; oz., $10 \mathrm{c} ; 1 / 4 \mathrm{lb} ., 25 \mathrm{c} ; 1 \mathrm{lb} ., 75 \mathrm{c}$.

KOLB'S GEM.-Fruit of the largest size; round or slightly oval; marked with irregular mottled stripes of dark and light green; outer rind or shell exceedingly hard and firm, making it a good sort for shipping long distance; flesh bright red, solid and sweet. Pkt., $5 \mathrm{c}$; oz., $10 \mathrm{c} ; 1 / 4 \mathrm{lb} ., 25 \mathrm{c} ; 1 \mathrm{lb} ., 75 \mathrm{c}$.

CUBAN QUEEN.-Fruit large and solid; rind very thin and strong; ripens to the very center; skin striped with dark and light green; flesh bright red, crisp and very sugary. It is an excellent keeper, and bears transit well. Pkt., 5c; oz., 10c; 1/4 1b., 25c; 1 1b., 75c.

BLACK SPANISH.-Round; very dark green, with scarlet flesh, and black seeds. It is not so large as some of the other sorts, but has a very thin rind, and a rich, sugary flavor. Pkt., 5c; oz., 10c; 1/4 lb. 25c; $1 \mathrm{lb} ., 75 \mathrm{c}$.

GOLDEN HONEY.-The flesh is of deep, rich yellow color, and in delicious sweetness and rare quality reminds one of honey, being without exception the sweetest melon raised and an extra early sort. Pkt. 5c; oz., 10c; $1 / 4$ lb., 25c; 1 lb., $75 \mathrm{c}$.

CITRON, COLORADO PRESERVING.-Employed in making preserves; grows uniformly round and smooth; striped and marbled with light green; flesh white and solid; seeds red. Pkt., 5c; oz., $10 \mathrm{c} ; 1 / 4 \mathrm{lb} ., 25 \mathrm{c} ; 1 \mathrm{lb} ., 75 \mathrm{c}$.

\section{NASTURTIUM.}

Capucine grande-Maranuela-Ranziner oder Indische Kresse.

The seeds, while young and succulent, are picked and used as capers. The plants are also highly ornamental; the tall variety makes an excellent screen or covering for unsightly places in the garden.

TALL NASTURTIUM.-Per pkt., 5c; oz., 15c; 1/4 lb., 40c.

DWARF NASTURTIUM.-Per pkt. $5 \mathrm{c} ;$ oz., $15 \mathrm{c} ; 1 / 4 \mathrm{lb} ., 50 \mathrm{c}$.

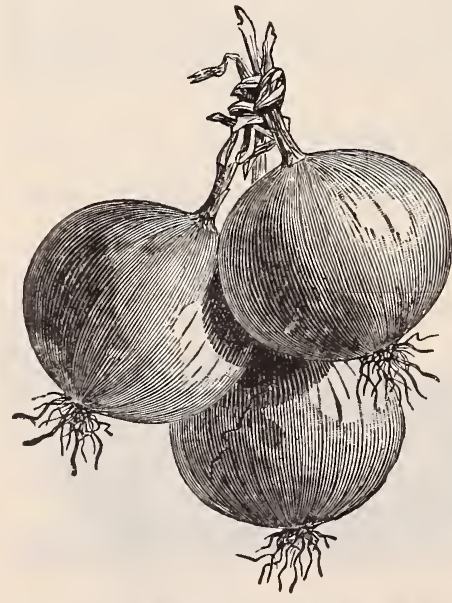

Onion-Yellow Globe Danvers.

\section{ONIONS.}

Ognon-Cebolla-Zwiebel.

The onion thrives best in a rather deep, rich, loamy soil, and, unlike most vegetables, succeeds well when cultivated on the same ground for successive years The ground should be deeply trenched and manured the previous autumn, and laid up in ridges during the winter to soften. As early in the spring as the ground is in working order commence operations by leveling the ground with a rake, and tread it firmly; sow thinly in rows, four pounds to the acre, and a quarter of an inch deep and one foot apart; cover with fine soil and press down with the back of a spade or light roller. When the young plants are strong enough, $t \mathrm{~h}$ i $\mathrm{n}$ gradually, so that they stand three 'or four inches apart. Keep the surface of the ground open and free from weeds by frequent hoeing, taking care not to

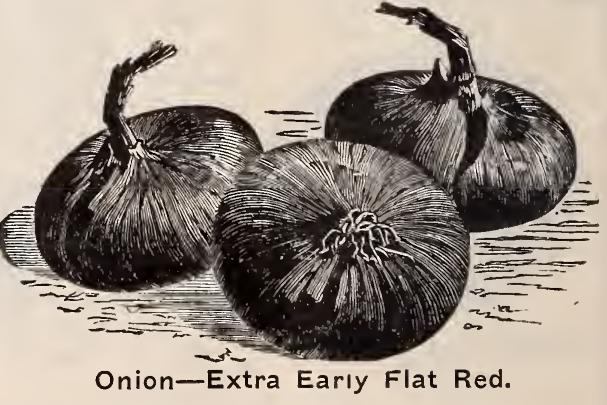


If by mail, postage must be added at the rate of 8 cents per pound.

On packets, ounces and quarter pounds, postage free.

\section{ONIONS-Continued.}

stir the soil too deeply or collect it about the growing bulb. When ripe, pull and dry thoroughly before storing. One ounce to 100 feet of drill; four to five pounds to an acre.

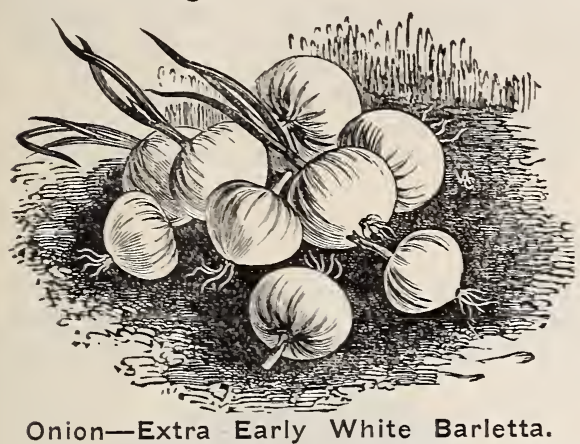

Onion-Extra Early White Barletta.

YELLOW GLOBE DANVERS.-A very excellent variety of globular shape, reliability for bottoming and large yield are both combined in this popular sort. It is grown extensively for market and very popular in Colorado. It is a handsome onion, quite thick through, of good size, with thin, yellow skin; flesh white, fine-grained and mild, and good keeper. Pkt., 5c; oz., 15c; I/4 lb., 40c; 1 lb. $\$ 1.25$; per 5-lb. lots, $\$ 1.00$ a lb.

YELLOW FLAT DANVERS.-Same as above in all its good qualities, only different in shape. Pkt., 5c; oz., 15c; I/4 lb., 40c; 1 lb., $\$ 1.25$; per 5-lb. lots, $\$ 1.00$.

OREGON YELLOW DANVERS. - It is a cross between the flat and the globe, and one of the best keepers for our western climate. Pkt., 5c; oz., 15c; I/4 lb., 40c; 1 lb., $\$ 1.25$; per 5-1b. lots, $\$ 1.00$ per lb.

EXTRA EARLY FLAT RED.-This varietv matures

unusually early. It yields abundantly; is of mild flavor and a good keeper; of medium size; deep red color; very close-grained; solid and heavy. Pkt., 5c; oz. $15 \mathrm{c} ; \mathrm{I} / 4 \mathrm{lb}$., $40 \mathrm{c} ; 1$ lb., $\$ 1.25$.

EARLY RED SOUTHPORT GLOBE.-Same as above in all its good qualities, but not quite so early; of very fine, globular shape. Plit., 5c; oz., 15c; $1 / 4$ lb., 50c; 1 lb., $\$ 1.50$.

BROWN AUSTRALIAN.-Is of medium size; wolnderfully hard and solid; the bulbs are most attractive for market, both as to form and appearance. They ripen evenly and extremely early; never showing any thick necks or scallions. The color of the skin is of a pale reddish brown; distinct from that of any other variety. Pkt., 5c; oz., 15c; I/4 lb., 40c; 1 lb., \$1.25; per 5-1b. lots, $\$ 1.00$ per lb.

EXTRA EARLY BARLETTA.-It is fully two or three weeks earlier than the Early White Queen, which heretofore has been the earliest variety in cultivation. They are of a pure, paper-white color; very mild and delicate in flavor; from one inch to one and a half inches in diameter and three-fourths of an inch in thickness. Pkt., 5c; oz., 20c; 1/4 1b., 60c; 1 lb., $\$ 2.00 ;$ per 5 -lb. lots, $\$ 1.75$ per lb.

EARLY WHITE QUEEN.-Succeeds well everywhere. The bulbs are small, flat, beautifully white, and of excellent flavor, but the principal recommendation is the marvelous rapidity of its growth. Sown in February it will produce onions one or two inches in diameter early in summer. Sown in July they will be ready to pull late in autumn; will keep sound for one year, retaining to the last their most exquisite flavor. Pkt., $5 \mathrm{c} ;$ oz., $20 \mathrm{c} ; 1 / 41 \mathrm{~b} ., 60 \mathrm{c} ; 1 \mathrm{lb} ., \$ 2.00$.

WHITE PORTUGAL OR SILVER SKIN.- A mild, pleasant flavored variety; the thin skin a clear, silvery white, of very handsome appearance; the bulbs grow to good size, ripening early and quite evenly. Pkt., 5c; oz., 20c; 1/4 lb., 50c; 1 lb., $\$ 1.50$.

BURPEE'S MAMMOTH SILVER KING.-This new onion grows to a most remarkable size. The skin is a beautiful silvery white; the flesh is snowy white, and of a particularly mild and pleasant flavor. Plkt., 5c; oz., 20c; 1/4 lb., 60c; 1 lb., $\$ 2.00$.

PRIZE-TAKER.-This new variety is without exception the largest and most handsome variety of onion ever grown. It is the large, beautiful onion that is seen every fall on sale at the fruit stores and stands in the large cities. The outside skin is a rich, yellow straw color, while the flesh is white, sweet, mild and tender. Pkt., 5c; oz., 20c; 1/4 1b., 50c; 1 lb., $\$ 1.50$.

WHITE LISBON.-Globe-shaped, large and good quality, suitable for bunching and early green onions. Pkt., 5c; oz., 10c; $1 / 4$ lb., 30c; 1 lb., $\$ 1.00$.

\section{ONION SETS.}

Add $10 \mathrm{c}$ per quart for mailing.

Special price on Bushel or Barrel lots.

Per Qt.

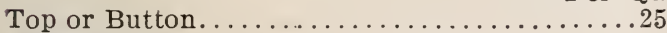

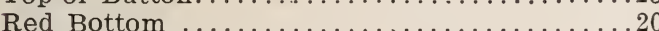

Yellow Bottom ........................20
Per Qt.

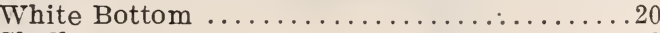

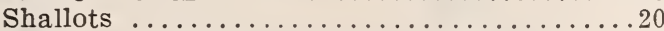

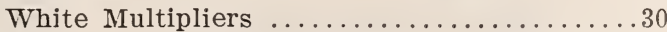


If by mail, postage must be added at the rate of 8 cents per pound.

On packets, ounces and quarter pounds, postage free.

\section{OKRA OR GUMBO.}

Gombo-Quimbomo-Ocker oder Gumbo.

This vegetable is extensively grown in the southern states. The long pods when young, are used in soups, stews, etc. It is of the easiest culture, and grows freely, bearing abundantly in any garden. One ounce to 40 feet of drill.

IMPROVED DWARF GREEN.-Early and productive. Per oz., 10c; 1/4 lb., 20c; 1 lb., 50c.

LONG GREEN.-Large green pods. Per oz., 10c; 1/4 lb., 20c; $1 \mathrm{lb} ., 50 \mathrm{c}$.

\section{PARSLEY.}

Persil-Peregil-Petersilie.

Parsley succeeds best in a rich, mellow soil. As the seeds germinate very slowly, three or four weeks elapse sometimes before it makes its appearance. It should be sown early in the spring, previously soaking the seeds for a few hours in tepid water. Sow thickly in rows a foot apart and half an inch deep. One ounce to 150 feet of drill.

DOUBLE CURLED.-A fine dwarf variety, beautifully curled, excellent for garnishing. Per oz., $10 \mathrm{c} ; 1 / 4 \mathrm{lb}$., $20 \mathrm{c} ; 1$ lb., $50 \mathrm{c}$.

CARTER'S FERN-LEAVED.-A very beautiful variety, being more like a crested fern or moss than parsley; very valuable for table decorations. Per oz., 10c; $1 / 4$ lb., 25c; 1 lb., 60c.

BEAUTY OF THE PARTERRE.-Distinct and most beautiful for edgings, and equally good as a condiment. Per oz., 15c; 1/4 lb., 30c; 1 lb., $\$ 1.00$.

\section{PARSNIPS.}

Panais-Chirivira-Pastinake.

Sow as early in the spring as the weather will permit, in drills fifteen inches apart, covering half an inch deep. When well up, thin out to five or six inches apart in the rows. Unlike carrots, they are improved by frost, and it is usual to take up in the fall a certain quantity for winter use, leaving the rest in the ground until

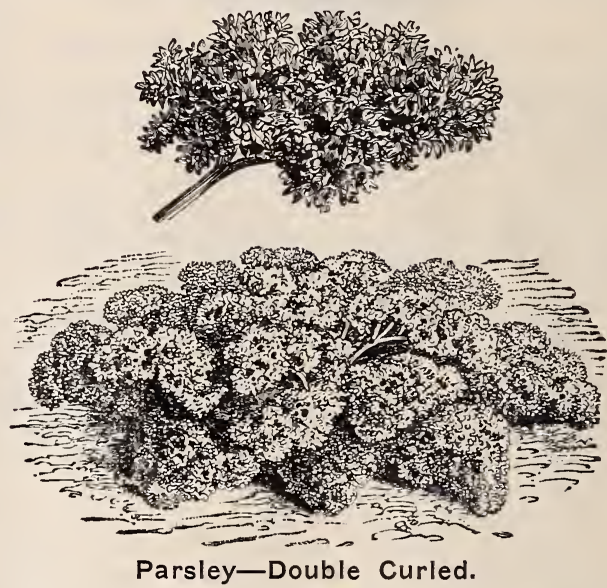

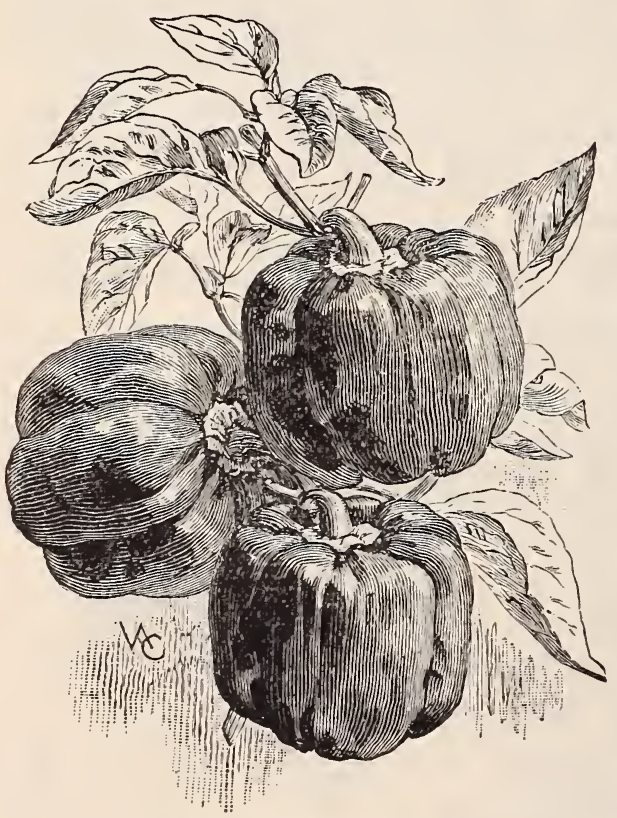

Pepper-Sweet Mountain. spring, to be dug up as required. One ounce to 120 feet of drill; five pounds to an acre.

GUERNSEY, or HOLLOW CROWN.-A greatly improved and wonderfully fine strain of Guernsey Parsnip. The roots do not grow so long as the long smooth, but are of greater diameter and more easily gathered. It is a very heavy cropper. The roots are very smooth; the flesh is fine-grained and of most excellent quality. Pkt., $5 \mathrm{c} ;$ oz., 10c; $1 / 4$ lb., 20c; per lb., 50c.

LONG SMOOTH, or SUGAR.-Roots very long, white, smooth, tender, sugary and most excellently flavored; very hardy. Per oz., 5c; 1/4 lb., 20c; 1 lb., 50c.

\section{PEPPER.}

\section{Piment-Pimiento-Pfeffer.}

Pepper should be started in hot-beds and transplanted to the open ground when the weather is favorable. They should be planted in warm, mellow soil, in rows eighteen inches apart. One ounce produces about 1,500 plants.

SWEET MOUNTAIN or IMPROVED BULL NOSE.An early variety of mild flavor; it is a strong grower; very productive and of excellent quality; the flesh is thick, sweet and mild. They often grow six inches long by four inches through. Pkt., $5 \mathrm{c} ; 1 / 4$ oz., 10c; $1 / 2$ oz., 15c; oz., 25c.

RUBY KING.-Grows four and one-half to six inches long by three and one-half to four inches thick. The peppers are a bright, ruby red; one of the best for 
On packets, ounces and quarter pounds, postage free.

If hy mail, postage must be added at the rate of 8 cents per pound.

\section{PEPPER-Continued.}

stuffed pickles. The plants grow from two and one-half to three feet in height, with fruits from three to four inches in diameter at the shoulder. The flavor is so exceptionally sweet and mild that the fruits may be eaten raw like a tomato. The meat or walls are quite thick, crisp and tender. Pkt., $5 \mathrm{c} ; 1 / 4 \mathrm{oz} ., 10 \mathrm{c} ; 1 / 2 \mathrm{oz} ., 15 \mathrm{c} ; 1 \mathrm{oz} ., 25 \mathrm{c}$.

LONG RED CAYENNE.-Small, long and tapering; very hot; best for seasoning pickles. Pkt., $5 \mathrm{c} ; 1 / 4$ OZ., $10 \mathrm{c} ; 1 / 2$ Oz., $15 \mathrm{c} ; 1$ oz., $25 \mathrm{c}$.

CHILI.-Pods shapely, conical; nearly two inches in length and half inch in diameter; brilliant scarlet when ripe, and exceedingly piquant. Pkt., 5c; 1/4 0z., 10c; $1 / 2$ oz., 15c; 1 oz., $25 \mathrm{c}$.

\section{PEAS-EARLY.}

Pois-Chicaros o Guisantes-Erbsen.

The pea is so generally used that it is needless to give any description of it. For early peas the soil should be light, warm and sheltered; but for general crop a moderately heavy soil is better. Sow, as early as possible, a few of the earliest varieties on warm, quick soil, prepared the fall before, and for the dwarf-growing kinds, the soil can hardly be too rich. One pound to fifty feet of drill; ninety pounds to the acre.

EARLIEST AND BEST.-One of the earliest smooth peas known; very desirable for market gardeners. It matures for table forty-five days from germination. Pkt., 5c; $1 / 2$ lb., $10 \mathrm{c} ; 1 \mathrm{lb} ., 15 \mathrm{c} ; 2$ lbs., 25c; per 10 -lbs., $\$ 1.00$.

ALASKA.-A variety of remarkable earliness and hardiness. It is a good yielder and produces pods of good size and dark green in color, which are well filled with round, smooth peas of splendid flavor; height, two feet; the color of the dried pea is green; it ripens very evenly, so that one picking will nearly clean off the crop. Pkt., 5c; 1/2 lb., 10c; 1 lb., 15c; 10-lb. lots, \$1.25.

AMERICAN WONDER.-This pea is a hybrid of fixed habit, between the Champion of England and the Little Gem; it possesses the merits of both, with some additional claims to notice. The vine grows eight to ten inches high, and is very prolific in pods of striking form and size. In maturity it is among the first earliest, ripening in about fifty days from germination. It is among the first early of the green wrinkled sorts. Its habit is so dwarf that it can be very successfully grown under glass. Pkt., 5c; I/2 lb., 10c; lb., 20c; $10 \mathrm{lb}$. lots, $\$ 1.60$.

NOTT'S EXCELSIOR.-Robust and vigorous in growth, inclined to throw out laterals from the base of the stock, producing in profusion long, handsome pods, closely packed with large peas of fine flaror. An improvement on American Wonder, being more vigorous and prolific, with larger pods, with more peas than either the Wonder or Premium Gem. A decided acquisition and sure to be very popular when generally known, and it will be some time before it can come into general use. Seed green; height, twelve inches. Pkt., 5c;1/2 1b., 10c; 1 lb. 20c; 10-1b. lots, $\$ 1.60$.

PREMIUM GEM.-A very desirable early dwarf, green wrinkled variety; very popular and more prolific than the Little Gem. Pkt., 5c; $1 / 2$ lb., 10c; 1 lb., 20c; 10 lbs., $\$ 1.50$.

\section{SECOND EARLY SORTS.}

YORKSHIRE HERO.-A wrinkled variety, maturing after the Premium Gem, but stronger in habit. It is hardy, productive, and of superior flavor. Pkt., $5 \mathrm{c} ; 1 / 2 \mathrm{lb}, 10 \mathrm{c} ; 1 \mathrm{lb}$., $15 \mathrm{c} ; 10 \mathrm{lbs}$., $\$ 1.25$.

PRIDE OF THE MARKET.-Seeds green; a week earlier than the Stratagem, but resembling it in habits of growth. The foliage and pods are, however, of a deeper green; the pods are from five to seven inches in length and well filled with very large peas; height, one and one-half feet. Pkt., $5 \mathrm{c} ; 1 / 2$ lb., 10c; 1 lb., 20c; 10 lbs. $\$ 1.50$.

EVER BEARING.-The vines attain a height of from eighteen inches to five feet; foliage large; the pods will average three to four inches in length, each pod producing six to eight wrinkled peas. These peas are very large, being half an inch and over in diameter, and in quality unsurpassed. For a continuance of bearing this variety is unexcelled. Pkt., 5c; 1/2 lb., 10c; 1 lb., $15 \mathrm{c} ; 10 \mathrm{lbs} ., \$ 1.25$.

STRATAGEM.-Seeds green, wrinkled; middle crop; one of the best peas ever sent out; grows a vigorous and showy vine, of branching habit; heavily laden with immense pods containing ten to twelve peas of large size; a marvelous cropper and incomparable eating pea; height, one and a half feet. Pkt., 5c; $1 / 2$ lb., $10 \mathrm{c} ; 1$ lb., $20 \mathrm{c} ; 10$ lbs., $\$ 1.50$.

TELEPHONE.- This new variety is one of the finest branching, tall, wrinkled marrows yet introduced. It is immensely productive, of the finest quality and excellent sugary flavor; vine very strong, averaging eighteen to twenty pods per stalk; the pods are of large size and closely packed with six or seven large, delicious peas; height, four feet. Every private garden should contain some of these magnificent peas; they are a sight worth seeing when in growth, and are luscious in quality on the table. Pkt., 5c; $1 / 2$ lb., $10 \mathrm{c} ; 1 \mathrm{lb} ., 20 \mathrm{c} ; 10 \mathrm{lbs} ., \$ 1.50$.

CHAMPION OF ENGLAND.-A variety possessing merit of high order. Superior to the common Marrowfat, which it resembles in strength of vine and general habit; wrinkled and very sugary; requires sticking; ripens for table use seventy days after germination. Pkt., 5c; $1 / 21 \mathrm{~b} ., 10 \mathrm{c} ; 1 \mathrm{lb}$., $15 \mathrm{c} ; 10$ lbs., $\$ 1.25$.

WHITE MARROWFAT.-A strong productive variety, requiring much space; not recommended 
On packets, ounces and quarter pounds, postage free.

If by mail, postage must be added at the rate of 8 cents per pound.

\section{PEAS-SECOND EARLY SORTS-Continued.}

for garden purposes, unless brushwood can be obtained; matures for table eighty days after germination. Plant on thin soil without manure. Pkt., 5c; 1/2 1b., $10 \mathrm{c} ; 1 \mathrm{lb} ., 15 \mathrm{c} ; 10 \mathrm{lbs} ., \$ 1.00$.

BLACK EYE MARROWFAT.-Very similar to the White Marrowfat, except the black eye in the seed. Pkt., 5c; $1 / 2$ lb., 10c; 1 lb., 15c; 10 lbs., $\$ 1.00$.

\section{FIELD PEAS.}

Field peas deserve more general cultivation. They are equal to corn in fattening hogs, and are ready to feed several weeks earlier. Can be sown to advantage with oats or will do well alone. As a land fertilizer they are very beneficial. For such the crop should be plowed under when they begin to bloom. They will grow on most any land. We have the Golden Vine, which is a white seed, and the Green Canada, which is a green seed. Price, 1 lb., 10c; 10-1b. lots, 50c. For larger quantities ask for market price.

\section{PUMPKIN.}

Potiron-Calabaza-Kurbus fur Torten und Ruchen.

Pumpkins are now principally cultivated for agricultural purposes. They are usually planted in fields of corn or potatoes, but may be profitably raised in fields by themselves. Sow first of May, in hills eight feet apart. One ounce to 40 hills; four pounds to an acre.

SUGAR PUMPKIN.-Smaller than the field pumpkin, but finer grained, sweeter and very prolific; first-rate for the table or stock. Per oz., 10c; 1/4 lb., 25c; 1 lb., $75 \mathrm{c}$.

TENNESSEE SWEET POTATO.-This sort has as sweet a flavor as any squash. For cooking purposes it is the finest of all pumpkins. Per oz., $10 \mathrm{c} ; 1 / 4 \mathrm{lb} ., 30 \mathrm{c} ; 1 \mathrm{lb} ., \$ 1.00$.

LARGE TOURS, or MAMMOTH.-Grows to an immense size, often weighing over one hunndred pounds. Per. Oz., 10c; I/4 lb., 40c; 1 lb., $\$ 1.50$.

CONNECTICUT FIELD PUMPKIN.-Very productive; largely grown for feeding stock. Per oz., $5 c ; 1 / 4$ lb., 15c; 1 lb., $40 \mathrm{c}$.

\section{RHUBARB.}

Rhubarbe-Raibarbe-Rhabarber.

Rhubarb succeeds best in deep, somewhat retentive soil. The richer its condition and the deeper it is stirred, the better. Sow in drills an inch deep and thin out the plants to six inches apart.

LINNAEUS.-The earliest of all and very productive and highly flavored. Per oz., 15c; 1/4 lb., $50 \mathrm{c} ; 1$ lb., $\$ 1.50$.

VICTORIA.-Very large; later than Linnaeus. Per oz., 15c; 1/4 1b., 50c. 1 lb., \$1.50.

\section{RADISH.}

Radis-Rabanos-y Rabanitos-Radies und Rettig.

Our stock of Radishes are grown especially for us by the well-known firm of Vilmorin, Andrieux $\&$ Cie., of Paris, France, and are the choicest that can be produced. For the first crop sow as early in the spring as the ground can be worked and every two weeks throughout the season, for a succession of crops. A warm, sandy loam, made rich and light by some good, strong manure, which is thoroughly rotted, will be most likely to afford them brittle and free from worms. One ounce to one hundred feet of drill; ten pounds to an acre.

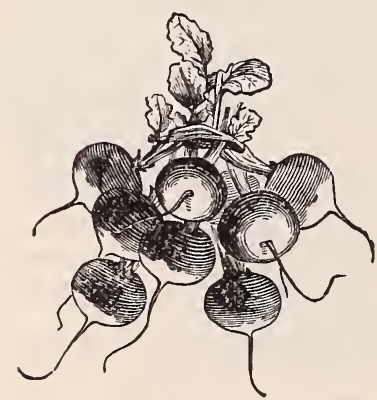

Radish-White Tipped Scarlet Turnip.
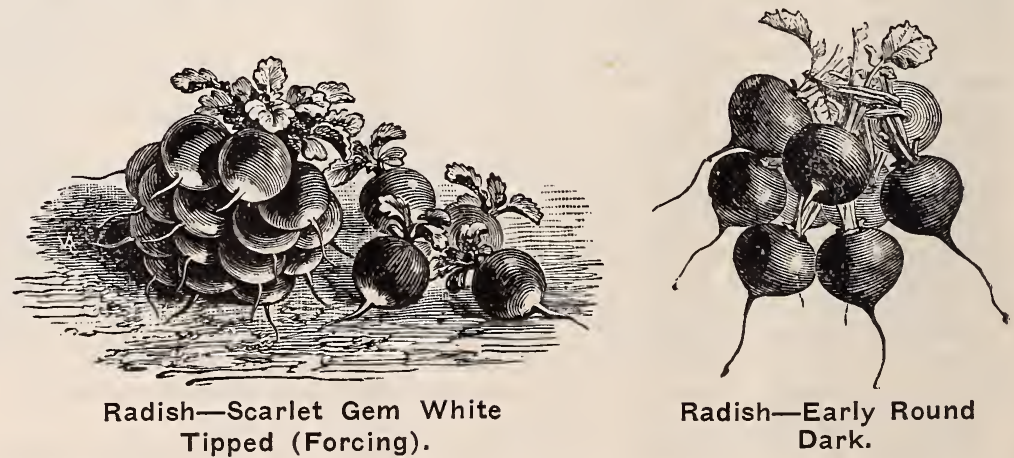

Radish-Early Round Dark. 
Ii by mail, postage must be added at the rate of 8 cents per pound.

On packets, ounces and quarter pounds, postage free.

\section{RADISH-Continued.}

SCARLET GEM, WHITE-TIPPED-FORCING.-This beautiful new variety is without doubt the best sort to grow under glass or hot-beds for early market. It is of deep scarlet, white tip; turnip-shape; making small tops, and it will, on that account, be particularly valuable for forcing, for which we specially recommend it. Pkt., 5c; oz., 10c; 1/4 lb., 25c; 1 lb., 75c.

EARLIEST ROUND DARK, or SCARLET BUTTON. -Its shape is of the best type of the round sorts; color of skin is very dark red; white flesh, with very small tap-root; well adapted for forcing and early out-door planting; very popular in Colorado. Pkt., 5c; oz., 10c; 1/4 lb., 20c; $1 \mathrm{lb} ., 60 \mathrm{c}$.

CINCINNATI MARKET, or GLASS.-The tops of this new radish are very small and may stand much closer in the rows than Wood's Early Frame or Long Scarlet, without danger of running to seed. They grow straight and smooth, and from six to seven inches long; the flesn is very tender, crisp and delicious, never becoming pithy or hollow; the skin is very thin, and is of an attractive, bright scarlet color. Pkt., $5 \mathrm{c}$; oz., $10 \mathrm{c} ; 1 / 4 \mathrm{lb} ., 20 \mathrm{c} ; 1 \mathrm{lb} ., 60 \mathrm{c}$.

WHITE-TIPPED SCARLET TURNIP.-A handsome, very early round sort; skin bright scarlet on top and shading to white on bottom; crisp and fine and very popular with our Denver market gardeners; used more generally than any other kind. Pkt., $5 \mathrm{c}$; oz., $10 \mathrm{c} ; 1 / 4 \mathrm{lb} ., 20 \mathrm{c} ; 1 \mathrm{lb} ., 60 \mathrm{c}$

EARLY SCARLET TURNIP.-A small, round, turnip-shaped, with small top, and of very quick growth. Pkt., 5c; oz., 10c; 1/4 lb., 20c; 1 lb., 50c.

FRENCH BREAKFAST or OLIVE-SHAPED.-A variety of quick growth;

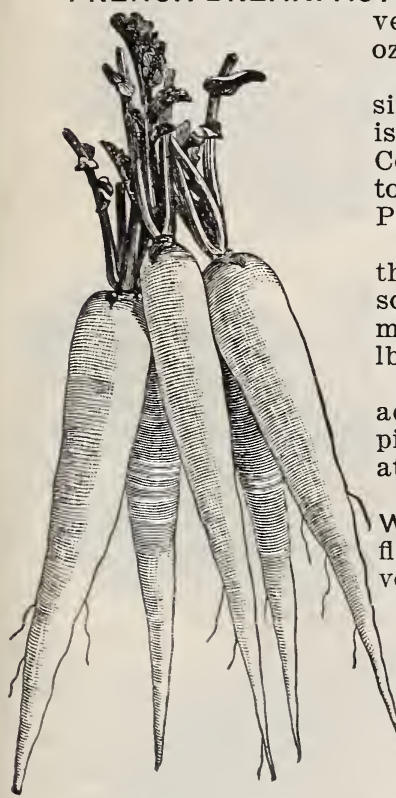

Radish-Long White Vienna. very mild and tender; used for forcing. Pkt., $5 \mathrm{c}$; oz., 10c; $1 / 4$ lb., 20c; 1 lb., 60 .

EARLY LONG SCARLET, SHORT TOP.-Grows six or seven inches long, half out of the ground; is very brittle and crisp, and of quick growth. Color, bright scarlet; small top; tapers regularly to the root, and is uniformly straight and smooth. Pkt., 5c; oz., 10c; 1/4 lb., 20c; 1 lb., 50c.

WOOD'S EARLY FRAME.-Not quite so long as the Long Scarlet, but a little thicker; of brilliant scarlet color; mild, brittle, of fine flavor, and the most suitable for forcing. Pkt., $5 \mathrm{c}$; oz., $10 \mathrm{c}$; $1 / 4$ lb., 20c; 1 lb., 60c.

CHARTIER LONG SCARLET.-It is perfectly adapted for very early growth. In color it is deep pink or crimson at the top, shading to a pure white at the tip. Pkt., 5c; oz., 10c; $1 / 4$ lb., 20c; $1 \mathrm{lb}, 60 \mathrm{c}$

LONG BRIGHTEST SCARLET OR CARDINAL, WHITE-TIPPED.-So named on account of its flesh, which is transparent white; crisp, mild flavor, and brittle; it is a fine radish, with white tip, and very uniform in growth. Pkt., 5c; oz., $10 \mathrm{c} ; 1 / 4$ lb., $20 \mathrm{c} ; 1 \mathrm{lb} ., 60 \mathrm{c}$.

LONG WHITE VIENNA, or LADY FINGER.-A splendid white summer variety; very tender and crisp; very popular with our Colorado market gardeners. Pht. $5 \mathrm{c} ;$ oz., $10 \mathrm{c} ; 1 / 4$ lb., $20 \mathrm{c} ; 1 \mathrm{lb} ., 60 \mathrm{c}$

LARGE WHITE SUMMER TURNIP.-

Flesh pure white and semi-transparent. It is a few days later than the Early Tur-

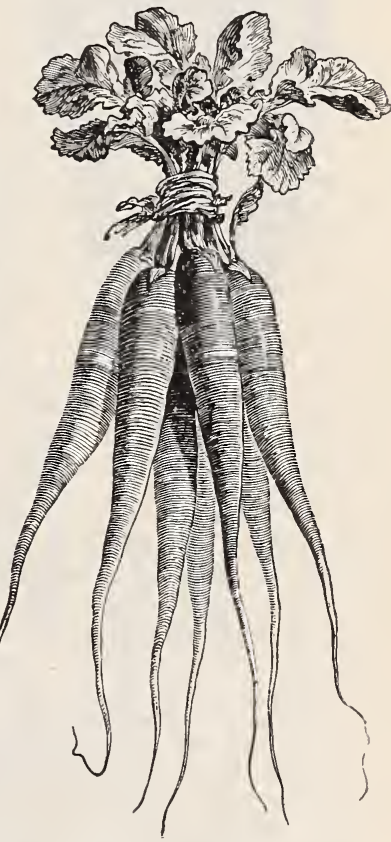

Radish-Early Long Scarlet.

nip sorts, but will bear the heat longer without becoming spongy. Pkt., 5c;oz., 10c;1/4 lb., $20 \mathrm{c} ; 1 \mathrm{lb}$., 60c.

YELLOW SUMMER TURNIP.-An oblong, turnip-shaped and russet colored sort, growing much larger than the white or red turnip varieties, and stands the extreme heat better than any other kind. Pkt., 5c; oz., 10c; 1/4 lb., 20c; 1 lb., 60c.

WHITE STRASBURG.-The most valuable summer radish in cultivation. Flesh pure snowwhite, tender and of a pleasant, pungent taste, without being strong. Per oz., 10c; 1/4 lb., 20c; $1 \mathrm{lb} ., 60 \mathrm{c}$.

CHINA ROSE.-Roots cylindrical, or largest at the bottom tapering abruptly to a small top; skin very smooth, and of a bright rose color; flesh as solid as an apple; a very good keeper. Pkt., 5c; oz., $10 \mathrm{c} ; 1 / 4$ lb., $20 \mathrm{c} ; 1 \mathrm{lb} ., 60 \mathrm{c}$

BLACK ROUND SPANISH.-One of the latest, as well as the hardiest of the radishes, and is considered an excellent sort for winter use; roots turnip-shaped; very large size and firm texture. Pkt., 5c; oz., 10c; 1/4 lb., 20c; 1 lb., 60c.

\section{SWISS CHARD.}

LARGE RIBBED CURLED.-The mid-rib alone of the leaf of this variety of beet is used. It is boiled as asparagus. The root is worthless. One ounce to 50 feet of drill. Pkt., $5 \mathrm{c} ; 0 \mathrm{z} ., 10 \mathrm{c} ; 1 / 4$ lb., $20 \mathrm{c} ; 1$ lb., $50 \mathrm{c}$. 
THE L. A. WATKINS MERCHANDISE COMPANY.

If by mail, postage must be added at the rate of 8 cents per pound.

On packets, ounces and quarter pounds, postage free.

\section{SALSIFY, or Oyster Plant.}

Salsifis-Rarba-Cabrana-Bocksbart.

The Oyster Plant succeeds best in light, well-enriched, mellow soil, which, previous to sowing the seeds, should be stirred to the depth of eighteen inches. Sow early in the spring, in drills fifteen inches apart; cover the seeds with fine soil, an inch and a half in depth. One

LARGE WHITE FRENCH.-Pkt., 5c; oz., 15c; I/4 1b., 40c; 1 lb., \$1.00.

\section{SAGE.}

The leaves are tender and tops are used in stuffing and sauces. Broad Leaved. Per pkt., 5c; oz., 15c; 1/4 lb., $40 \mathrm{c}$.

\section{SORREL.}

Oseille-Acedera-Sauerampfer.

LARGE-LEAVED FRENCH.-Much used for salad. Per pkt., 5c; oz., 15c; I/4 lb., 50c.

\section{SPINACH.}

Epinard-Epinaca-Spinat.

This is a very important crop in our market gardens, and is one of the most easily managed of all vegetables, requiring but little culture. The main crop is sown in September, and it is sometimes covered with straw in exposed places during winter, which prevents it from being cut with the frost. For summer use it may be sown at intervals of two or three weeks from March to August. Spinach is best developed and most tender and succulent when grown in rich soil. One ounce to one hundred feet of drill; ten pounds to twelve pounds to an acre.

MONSTROUS VIROFLAY. - A Salsify. new variety, with very large thick leaves. Equally as good for fall or spring sowing. Per oz., 5c; r/4lb., 15c; 1 lb., $30 \mathrm{c} ; 5$ lb. lots, $25 \mathrm{c}$ per lb.

LARGE DUTCH ROUND LEAF.-The main market sort; thick leaves; equally as good for fall or spring sowing. Per oz., 5c; $1 / 4$ lb., $15 \mathrm{c} ; 1$ lb., $30 \mathrm{c} ; 5$ lb. lot $25 \mathrm{c} 1 \mathrm{~b}$.

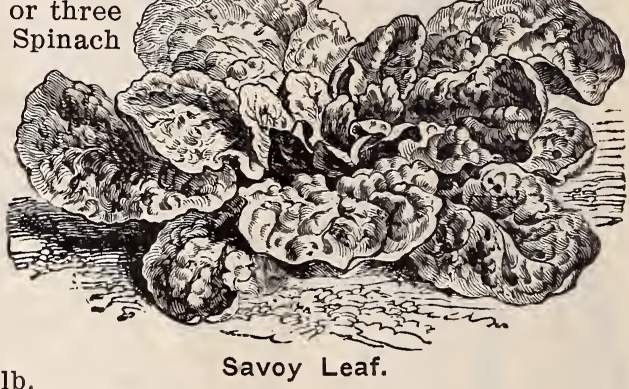

SAVOY LEAVED.-The leaves of this variety are large, of good substance, and curled like the Savoy Cabbage; very productive. Per oz., $5 \mathrm{c}$; per 1/4 lb., $15 \mathrm{c}$; per lb., $30 \mathrm{c}$; 5 lb. lots, $25 \mathrm{c}$ per $1 \mathrm{~b}$.

LONG STANDING.-This variety has the valued characteristics of remaining a long time after being fully matured for market use, without running to seed. In other respects it closely resembles the round leaf. Quality very fine. Per oz., 5c; 1/4 lb., 15c; per lb., 30c; 5-lb. lots, $25 \mathrm{c}$ per 1b.

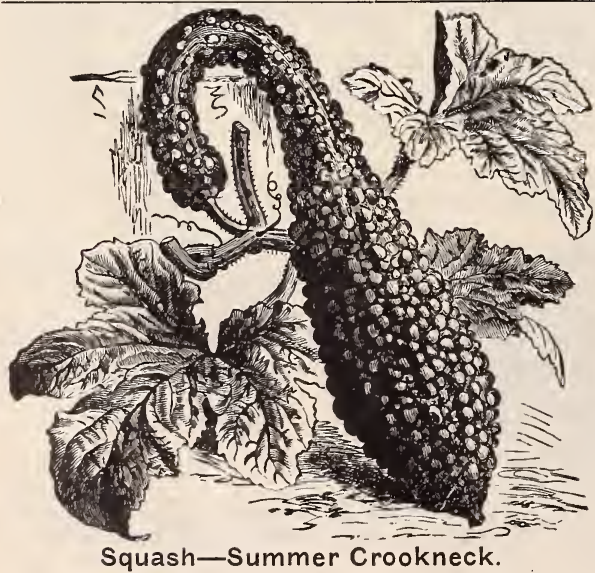

SQUASH.

Courge-Sidracayote-Speisekurbis.

Sow about the middle of spring, in hills, the early sort about four feet apart, and the late varieties six to eight feet. Drop enough seeds to be thinned to three plants in a hill. The hills should be highly manured and prepared in a similar manner as those for cucumbers. One ounce to fifty hills for small sorts; large varieties, one ounce to fifteen hills; four or five pounds to an acre.

EARLY WHITE BUSH SCALLOPED.-An early, flat, scallop-shaped variety; color white; finely flavored; very productive. Pkt., 5c; oz., 10c; 1/4 lb., 25c; lb., 75c.

EARLY YELLOW BUSH SCALLOPED.-Identical with the preceding, except in color, which is yellow. Pkt., 5c; oz., 10c; 1/4. 1b., 25c; 1 lb., 75c.

EARLY BUSH SUMMER CROOKNECK.-Very early and productive. One of the best for summer use; it is small, crooknecked; color yellow; shell hard when ripe. Pkt. 5c; oz., 10c; 1/4 lb., $25 \mathrm{c} ; 1$ lb., $75 \mathrm{c}$ 
If by mail, postage must be added at the rate of 8 cents per pound. On packets, ounces and quarter pounds, postage free.

\section{SQUASH-Continued.}

HUBBARD.-A general favorite, and more largely grown in Colorado than any others; it is of large size, often weighing from nine to ten pounds. Color bluish green, occasionally marked with brownish orange or yellow; flesh fine-grained, dry and of excellent flavor, and a good keeper. Pkt., 5c; oz., 10c; 1/4 lb., 30c; 1 lb., $\$ 1.00$.

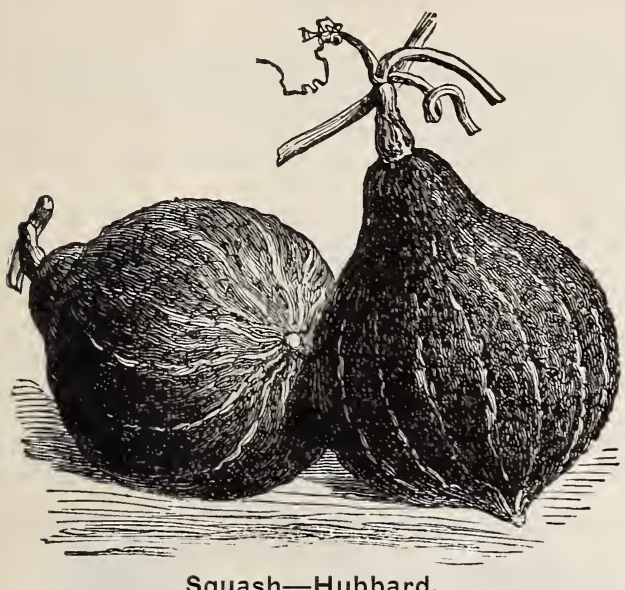

Squash-Hubbard.
WARTY HUBBARD.-This is a superior variety, and the best winter squash known; flesh bright orange yellow; fine-grained; very dry; sweet and rich flavored; keeps perfectly good throughout the winter, but a little smaller than the Hubbard. Pkt. $5 \mathrm{c}$; oz., $10 \mathrm{c}$; $1 / 4 \mathrm{lb} ., 40 \mathrm{c} ; 1 \mathrm{lb} ., \$ 1.25$.

BOSTON MARROW.-A much esteemed variety, coming in about ten days later than the bush sorts; oval in form; color of skin, bright orange; flesh yellow; a good keeper and unsurpassed flavor. Pkt., $5 \mathrm{c}$; oz., 10c; 1/4 lb., 40c; 1 lb., \$1.25.

MARBLEHEAD.-This squash as a rule is characterized by a shell of more flinty hardness than the Hubbard; the flesh is of a rather lighter color than the Hubbard; its outer color is a light blue. Pkt., 5c; oz., 10c; $1 / 4$ lb., 40c; 1 lb., $\$ 1.25$.

MAMMOTH CHILI.-This squash attains an enormous size, often weighing 200 to 300 pounds; very profitable for stock feeding, especially where root crops are not grown extensively; remarkably productive. Pkt., 5c; oz., 15c; 1/4 lb., 50c; 1 lb., $\$ 1.50$.

\section{TOMATO.}

Tomate-Tomates-Liebesapfel.

The Tomato is now one of the most important of all garden vegetables. When the plants are to be raised, the seed should be sown in March, in a hot-bed or greenhouse; or they may be sown in a

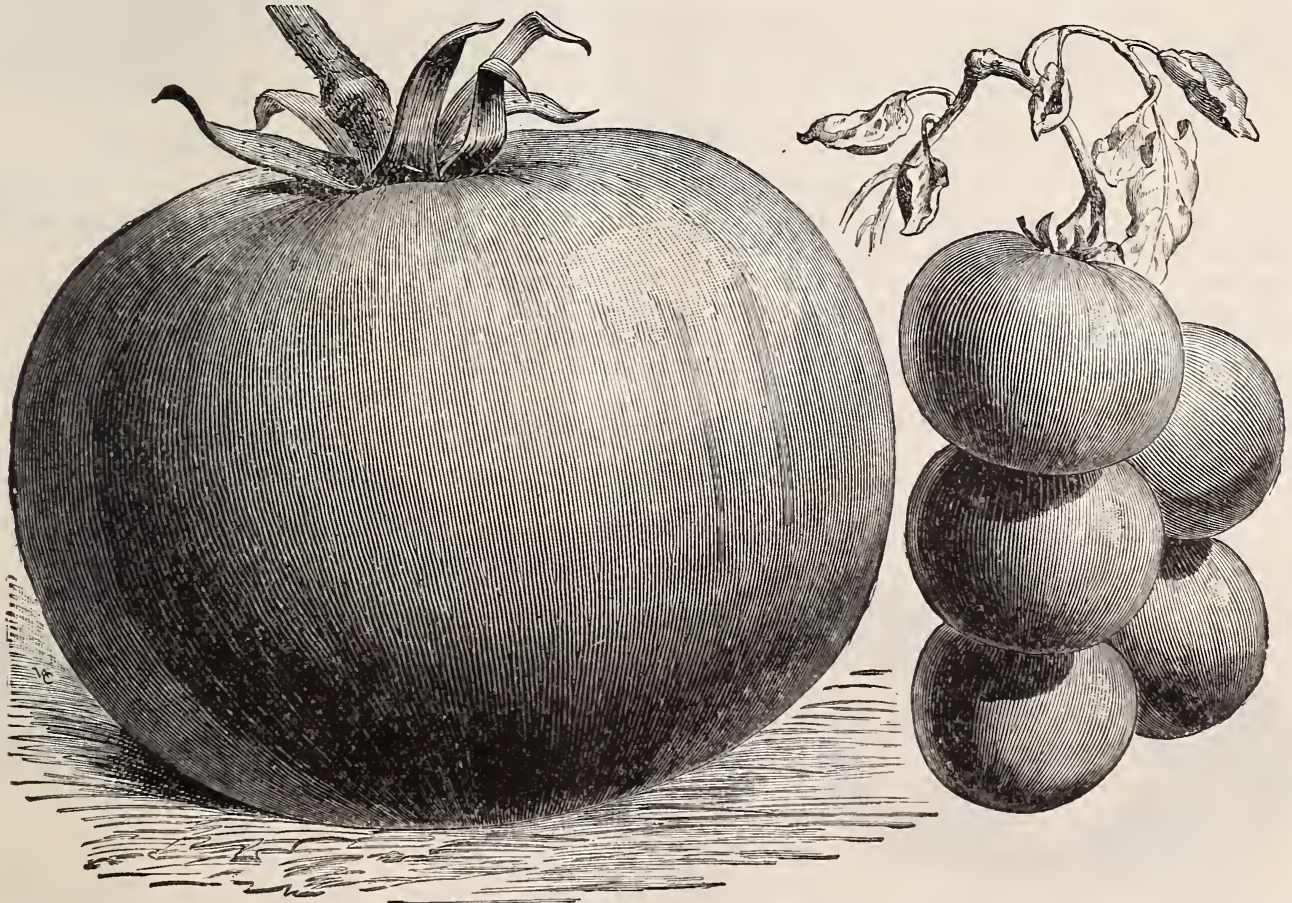

Tomato-Livingston's Beauty. 
If by mail, postage must be added at the rate of 8 cents per pound.

On packets, ounces and quarter pounds, postage free.

\section{TOMATO-Continued.}

box and kept inside the window of a room where the night temperature is not less than sixty-five degrees. About the middle of May the plants may be set in the open ground. Our stock of Tomatoes are all Livingston's own growth, and the best in the market.

LIVINGSTON'S PERFECTION.-Solid flesh; always smooth and of blood-red color; this is a general favorite, equally desirable for the home garden, for shipping and for canning. Pkt., 5c; 1/2 oz., $15 \mathrm{c}$; oz., 20c; 1/4 lb., 60c; 1 lb., $\$ 2.25$.

LIVINGSTON'S FAVORITE.- -It is the largest perfect-shaped tomato in cultivation; it has no green core; is as smooth as an apple; never cracks after ripening; it is a brilliant dark, glossy red color; ripening all over and through, evenly. Pkt., 5c; 1/2 oz., 15c; oz., 20c; 1/4 lb., 60c; 1 lb., $\$ 2.25$.

LIVINGSTON'S BEAUTY.- One of the best of this famous grower; glossy crimson with purple tinge; holds its size well late in the season; its tough skin makes it a good shipper and the favorite in Colorado. Pkt., 5c; $1 / 2$ oz., 15c; oz, 20c; $1 / 4$ lb., 60c; 1 lb., \$2.25.

NEW STONE.-We call this King of the Livingston kinds, which are the best types of large, smooth, solid "beefy" tomatoes; ripening evenly to the stem without a crack; exceedingly solid and firm-fleshed (as its name indicates); is an excellent shipper; quality the very best. Pkt., $5 \mathrm{c} ; \mathrm{r} / 2$ oz., 15c; 1oz., 20c; r/4 1b., 60c; 1 lb., $\$ 2.25$.

LIVINGSTON'S MAGNUS.-A new variety. It is very distinct, having the color of Livingston's Beauty and Acme, but thicker, heavier and more solid than either; the form is uniformly perfect; large and attractive; very deep from blossom to stem end, and almost globe-shaped; flesh is firm, and flavor most desirable. Pkt., 5c; 1/2 oz., 15c; oz., 25c; 1/4 1b., 75c; 1 lb., $\$ 2.50$.

DWARF CHAMPION.-A great favorite; its dwarf habit and upright growth permit close planting; color purplish pink; always smooth and symmetrical; fine quality and solid-meated. Pkt., 5c; $1 / 2$ oz., 20c; oz., 30c; r/4 lb., $\$ 1.00 ; 1$ lb., $\$ 3.00$.

YELLOW PLUM.-Color bright yellow; excellent for preserving. Pkt., 5c; 1/2 oz., 15c; oz., 25c; $1 / 4$ lb., $75 \mathrm{c}$.

RED PLUM.-Same as above, except color. Pkt., 5c; 1/2 oz., 15c; 1 oz., 25c; 1/4 lb., $75 \mathrm{c}$

RED CHERRY.-A small, early variety; size and shape of a cherry. Pkt., 5c; 1/2 oz., 15c; $1 \mathrm{oz}$., $25 \mathrm{c} ; 1 / 4 \mathrm{lb} ., 75 \mathrm{c}$.

HUSK TOMATO, or GROUND CHERRY.-This is much liked by many for preserves and for eating from the hand; it makes also good pies, and is very fine dried in sugar. Pkt., 5c; 1/2 oz., 15c; oz., $25 \mathrm{c} ; \mathrm{r} / 4 \mathrm{lb} ., 75 \mathrm{c}$.

\section{TOBACCO.}

Tabac-Taback-Saamen.

CONNECTICUT SEED LEAF.-Pkt., 5c; 1/2 oz., 15c; oz., 25c.

\section{TURNIP.}

\section{Navet-Cabo-Weisse Rube.}

Turnips do best in highly enriched, light, sandy or gravelly soil; commence sowing the earliest varieties in April, in drills from twelve to fifteen inches apart, and thin out early to six or nine inches in the rows. For a succession, sow at intervals of a fortnight until the last week in July, from which time until the end of August sowing may be made for the fall and main crop. One ounce will sow 150 feet of drill; one and one half pounds to an acre.

EXTRA EARLY WHITE MILAN.-The earliest in cultivation.

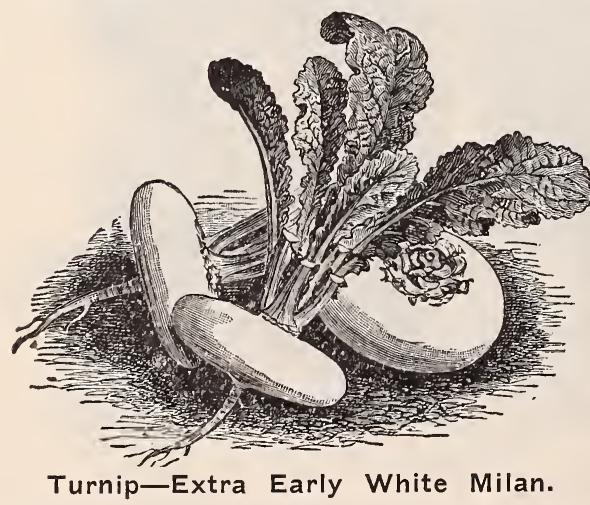
The bulb is very flat, of medium size, quite smooth and being pure white flesh, makes it the choicest of all on account of its sweetness; has taken the place of the purple top variety, which $\mathrm{h}$ a s sometimes a bitter taste, being a pure white, it makes it specially desirable for forcing. Pkt., 5c; oz., 10c; $1 / 4$ lb., 25c; 1 lb., 75c.

EARLY SNOW. BALL.-A medium-sized, round, pure white

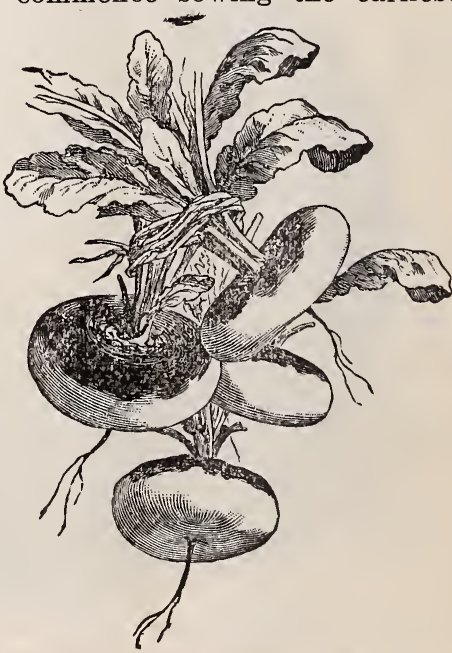

Turnip-Early Purple Top Strap-leaved. 
It by mail. postage must be added at the rate of 8 cents per pound. On packets, ounces and quarter pounds, postage free.

\section{TURNIP_Continued.}

variety of excellent flavor. For early sowing this is one of the best, being crisp, tender and sweet, maturing in six weeks from time of sowing. Pkt., 5c; oz., 10c; 1/4 1b., 20c; $1 \mathrm{lb} ., 60 \mathrm{c}$.

EARLY WHITE EGG.-A quick-growing variety, perfectly smooth and nearly egg-shaped; in color it is pure white; of extraordinary firmness and solidity; grows about half out of the ground; has small top and rough leaves; the flesh is very sweet, firm and delicious. Pkt., 5c; oz., 10c; 1/4 lb., 20c; 1 lb., 60c.

EARLY PURPLE TOP, STRAP-LEAYED.-The standard of this part of the country; superior for early or late planting; round, flat, good sized; small top, with but few leaves; flesh very finegrained and well flavored. Plkt., 5c; oz., 10c; 1/4 lb., 20c; 1 lb., 50c.
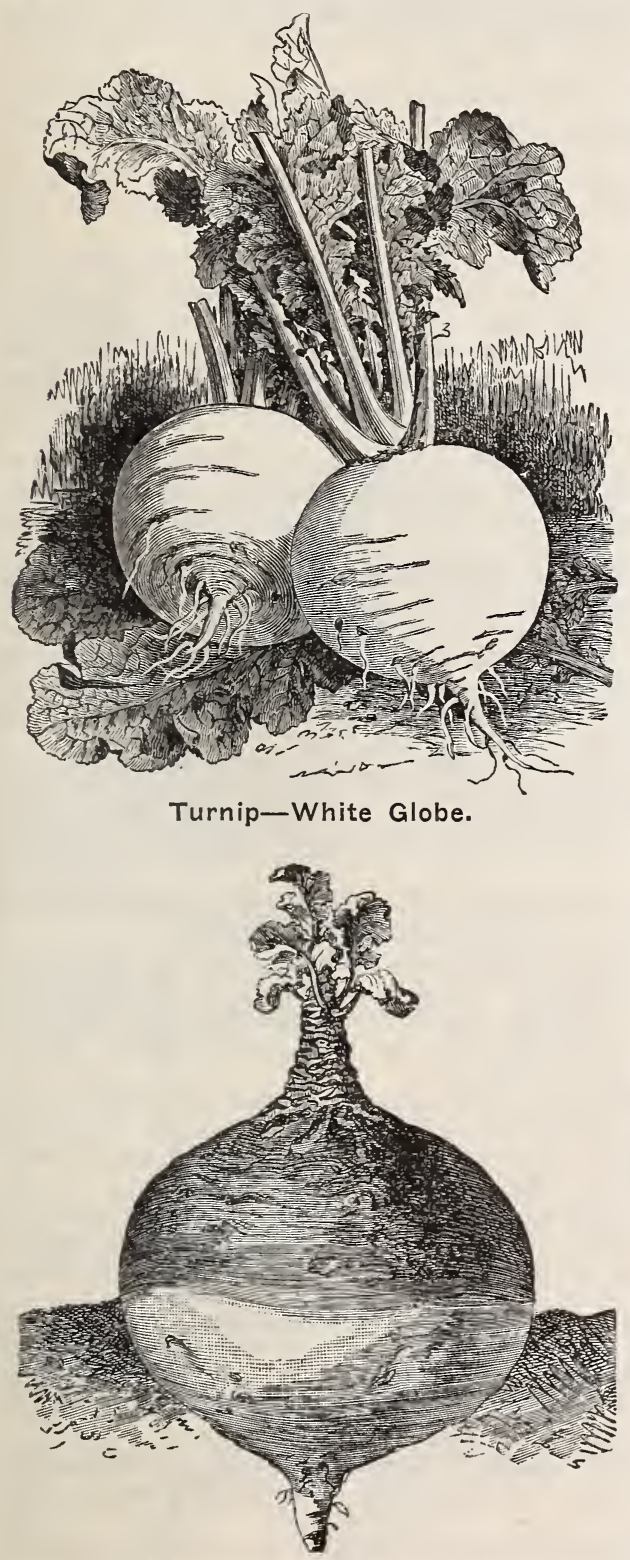

Rutabaga-Skirving's Purple Top.
EARLY WHITE FLAT DUTCH, STRAP-LEAVED. - This is a popular early variety for table use; medium size; of quick growth; juicy and of excellent quality. Per pkt., 5c; oz., 10c; 1/4 lb., 20c; lb., 50c.

EARLY RED TOP GLOBE.-Globe-shape; large; firm in texture; juicy, and of exceedingly quick growth, and very hardy and productive. Pkt., $5 \mathrm{c} ;$ oz., $10 \mathrm{c} ; 1 / 4$ lb., 20c; 1 lb., 50c.

POMERANIAN WHITE GLOBE.--It is one of the most productive kind. In good, rich soil the roots will frequently grow to twelve pounds in weight; it is of the most perfect globe-shape; skin white and smooth; leaves dark green and of a strong growth. Pkt., 5c; oz., 10c; $1 / 4$ lb., 20c; 1 lb., 50c.

AMBER GLOBE.-Is one of the best American varieties for general crop; flesh very firm and sweet, and keeps well until late in spring; grows to a large size, and is excellent either for stock or table use. Pkt., 5c; oz., 10c; 1/4 lb., 20c; 1 lb., 50c.

YELLOW ABERDEEN.-Very hardy and productive; good lieeper; globe-shaped; color pale yellow with purple top; very firm in texture, and closely resembling the rutabaga in good keeping qualities; good for either table or stock. Pkt., 5c; oz., 10c; 1/4 1b., 20c; 1 1b., 50c.

LONG WHITE, or COW HORN.-Matures very quickly; roots shaped like a carrot, about half of which is found above ground. Flesh white, fine-grained and sweet, and of excellent quality for table use. Pkt., 5c; oz., $10 \mathrm{c} ; 1 / 4$ lb., 20c; 1 lb., $50 \mathrm{c}$.

\section{RUTABAGA, or Swedish Turnip.}

The Rutabaga, or Swedish Turnip, is extensively crown for a farm crop; the roots are close-grained, very hard, and will endure a considerable degree of cold without injury; the roots are best preserved in a pit or cellar during the winter, and are excellent for table early in the spring. Sow from June 20 th to the middle of July, in drills two feet apart, and thin out to eight inches.

SKIRVING'S PURPLE TOP.-The best variety of Swedish Turnip in cultivation. Hardy and productive; flesh yellow; of solid texture; sweet, and well flavored; shape slightly oblong; terminates abruptly with no side or bottom roots; color deep purple above, and bright yellow under the ground; leaves small, light green; the most perfect in form; the richest in flavor, and the best in every respect. Pkt., 5c; oz., 10c; 1/4 lb., 20c; 1 lb., $50 \mathrm{c}$.

SWEET GERMAN.-A superior variety for table or stock; flesh white, sweet and juicy. Pkt., 5c; oz., 10c; $1 / 4 \mathrm{lb}, 20 \mathrm{c} ; 1 \mathrm{lb} ., 60 \mathrm{c}$. 
If by mail, postage must be added at the rate of 8 cents per pound. On packets, ounces and quarter pounds, postage free.
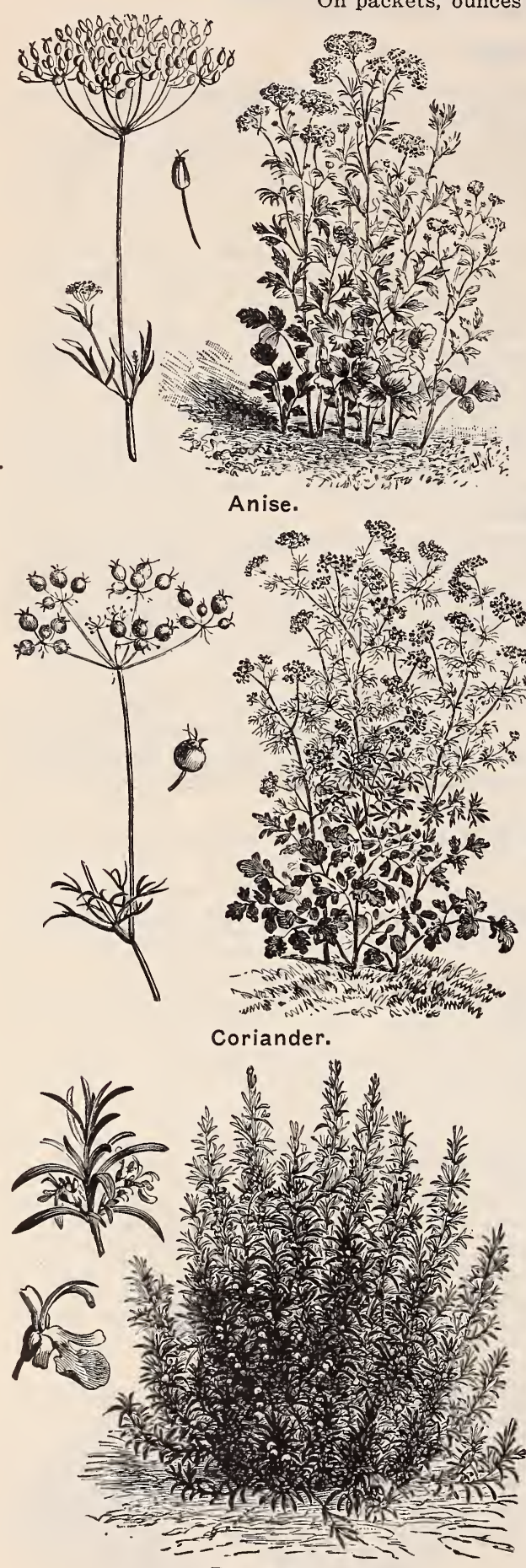

Rosemary.

SWEET HERBS.

Those marked with an asterisk (*) are perennial.

ANISE (Pimpinella Anisum).-Used for cordial, garnishing and flavoring; the seeds have an agreeable taste. Pkt., 5c; oz., 10c; $1 / 4$ lb., 30c.

BALM (Melissa Officinalis).-The leaves have a fragrant odor, and are used for making a pleasant beverage known as Balm Wine; also for balm tea, for use in fever. Per pkt., 5c; oz., 25c.

BORAGE (Borago Officinalis).-The leaves are used for flavoring, and the flowers furnish bee pasture. Per pkt., $5 \mathrm{c}$; oz., $15 \mathrm{c}$; $1 / 4$ lb., $40 \mathrm{c}$.

BASIL-SWEET (Ocymum Basilicum).-The leaves are used for flavoring soups, stews and highly seasoned dishes. Pkt., 5c; oz., 15c.

*CARAWAY (Carum-Carvi).-Chiefly cultivated for the seed, which is used in confectionery and medicine. Pkt., 5c; oz., 10c; 1/4 lb., 25c.

*CATNIP, or CATMINT (Nepeta Cataria).-Used as a medicinal herb, and also in bee feeding. Pkt., 5c; oz., (noc.

CORIANDER (Coriandrum Sativum).-Cultivated for garnishing but more frequently for its seeds, which are used by confectioners. Pkt., 5c; oz., 10c; 1/4 lb., $25 \mathrm{c}$.

DILL (Anethum Graveolens).-The seeds have an aromatic odor, and warm, pungent taste; they are used as a condiment, and also for pickling with cucumbers. kt., 5c; oz., 10c; 1/4 lb., 25c.

*FENNEL, SWEET (Anethum Foeniculum).-The leaves, boiled, enter into many fish sauces, and, green, form a beautiful ornament. Pkt., $5 \mathrm{c}$; oz., 10c; $1 / 4 \mathrm{lb}$., $25 \mathrm{c}$.

*HOREHOUND (Marrubium Vulgare).-The leaves are used for seasoning and also in the manufacture of the popular cough remedy. Pkt., 5c; oz., 20c.

*HYSSOP (Hyssopus Officinalis).-A hardy perennial with an aromatic flower and warm, pungent taste; it is a stimulant and expectorant and is used in asthma and chronic catarrh. Pkt., 5c; oz., 20c.

* LAVENDER (Lavendula Spica).-It is cultivated for its fragrant flowers, which are used for distilling lavender water. Leaves and flowers are aromatic. Gather the flowers before they begin to fade. Pkt., 5c; oz., 25c; $1 / 4$ lb., $75 \mathrm{c}$.

MARJORAM, SWEET (Origanum Majorana).-Used for seasoning. Pkt., $5 \mathrm{c}$; oz., $15 \mathrm{c} ; 1 / 4 \mathrm{lb} ., 40 \mathrm{c}$.

* ROSEMARY (Rosmarinus Officinalis).-A native of the south of Europe. It is used in many diseases quite successfully, among which are chlorosis and nervous headache. The tops only are used as medicine. Pkt. $5 c$; Oz., 40c; 1/4 1b., $\$ 1.00$.

* RUE (Ruta Graveolens).-Used for medicinal purposes; good for fowls, for the croup. Plkt., 5c; oz., 15c. SAFFRON.-Pick the flowers, and dry, for their medicinal qualitites. An annual. Pkt., 5c; oz., 20c.

*SAGE (Salvia Officinalis). -The most extensively used of all herbs for seasoning and dressing. Tea made from the leaves is an excellent sudorific. Perennial. Pkt., 5c; oz, 15c; 1/4 lb., 40c.

SUMMER SAVORY (Satureia Hortensis).-The leaves and flowers are used extensively for flavoring, particularly in soups and dressing. Pkt., 5c; oz., 10c; $1 / 4 \mathrm{lb}, 25 \mathrm{c}$

*TANSY (Tanacetum Vulgare).-Cultivated for its medicinal properties. Pkt., 5c; oz., 25c.

*THYME, FRENCH (Thymus Vulgaris).-The leaves and young shoots are used for seasoning; a tea is also made for nervous headache. Pkt., 5c; oz., 40c.

*WORMWOOD (Artemisia Absinthium).-Used medicinally, and is beneficial for poultry; should be planted in poultry yards. Pkt., 5c; oz., $15 \mathrm{c}$. 


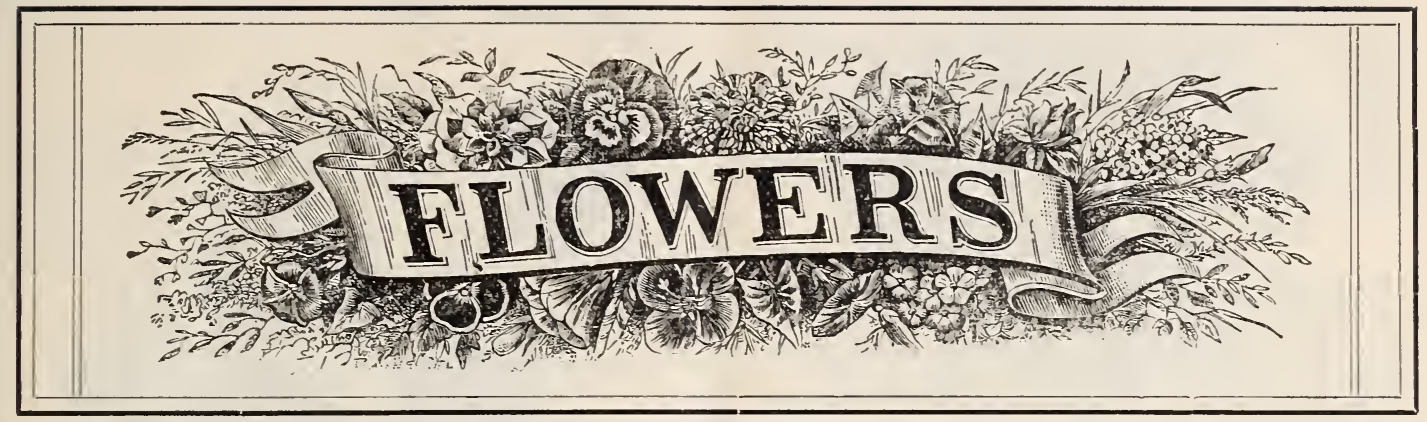

ANNUALS, BIENNIALS AND PERENNIALS.

\section{ALL FLOWER SEEDS SENT FREE BY MAIL ON RECEIPT OF PRICE.}

In the following pages we describe, arranged alphabetically, our list of standard varieties of Flower Seeds. The descriptions are accurate and the quality the very best, and, while our list may not prove the most extensive in the country, it will be found that all the varieties it embraces are worthy of general culture. We urgently request a trial order from those who have not sown our seeds, and we are convinced that they will become regular customers.

\section{ABRONIA.}

A handsome trailing plant, with clusters of sweet-scented flowers resembling Verbenas in shape, but of smaller size; color rose lilac, with white eye. Fine for baskets and vases, as well as the garden. Remove the husk from the seed before sowing, as it grows much surer. Height, 6 inches. Half-hardy annual.

Abronia Umbellata.-Per pkt., 5c.

\section{ABUTILON, or Flowering Maple.}

Desirable plants for the conservatory in winter, and effective border plants during summer, producing a profusion of lovely bell-shaped flowers. Half-hardy shrubs. Height, 2 to 6 feet; perennial.

Abutilon, Finest Mixed.-Per pkt., $15 \mathrm{c}$. ACONITUM (Monkshood).

Showy, hardy perennials, growing well under trees, shrubberies or other shaded situations.

Aconitum Napellus.-Blue and white; two feet. Pkt., 5c.

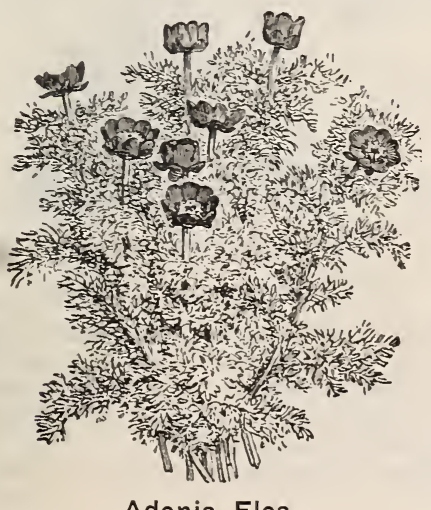

Adonis Flos.

\section{ADONIS FLOWER.}

Known as Pheasant's Eye. The flowers are very brilliant, but not very freely produced. The foliage is pretty, delicate and many parted. It will grow readily in a shaded place under a tree or by the fence, and requires no extra care in planting or cultivating. Hardy annual; one foot high.

Adonis Flos.-Scarlet; 1 foot. Per pkt., 5c.

\section{ACROCLINIUM.}

This beautiful, everlasting flower somewhat resembles the Rodanthe, but the flower heads are of larger size. It is largely used for winter bouquets, for which purpose the flowers should be cut before they are fully expanded Half-hardy annual.

Acroclinium Mixed.-Per pkt., 5c.

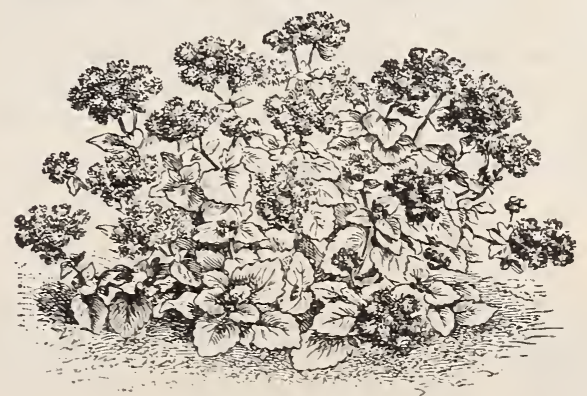

Ageratum Mexicanum.

\section{AGERATUM.}

A valuable plant on account of the length of time it remains in bloom, and for contrast of color with the more brilliant varieties. It blooms constantly all summer in the garden. Hardy annual.

Ageratum.-Dwarf Imperial Blue. Per pkt., 5c. 


\section{AGROSTEMMA (Crown of the Fields).}

Perfectly hardy plants, producing pretty pinklike blossoms on long, slender stems. Very useful for cutting for bouquets, and pretty in masses or in beds. The annual variety is known as Rose of Heaven, the perennial as Rose Campion. About $1 \frac{1}{2}$ feet high.

Agrostemma Coronaria.-(Fine mixed). Perennial. Per pkt., 5c.

\section{AMARANTHUS.}

Valuable for its varieties of handsome foliage, whether grown in the conservatory or garden. The colors will be more brilliant if planted in moderately rich soil.

Amaranthus Caudatus.-(Love lies bleeding). -Well known. Per pkt., 5c.

Amaranthus Tricolor.-Leaves yellow, red and green; well known as Joseph's Coat. Very showy in beds alone. Hardy annual; 2 feet high. Per pkt., 5c.

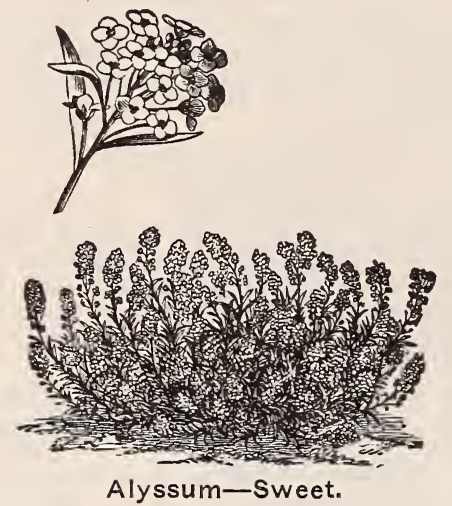

ALYSSUM.

Seedsmen, perhaps, sell more seed of Sweet Alyssum than of any other annual grown. Whether used for summer blooming or flowering in fall and winter in the parlor or greenhouse, its easy culture and the delicate, honeylike fragrance of its flowers, so much prized in bouquets and baskets, render it most unlikely that this old favorite will ever be cast aside.

Alyssum Sweet (Maritimum).-Flowe r s white; one foot; hardy annual. Per pkt., 5c.

\section{AMMOBIUM (Everlasting).}

A small, white immortelle, or everlasting, very useful for cutting when fresh, and drying admirably for winter bouquets; producing a succession of bloom from July till frost. Height, 18 to 24 inches. Hardy annual.

Ammobium Alatum.-Pkt., $5 \mathrm{c}$.

\section{AMPELOPSIS.}

One of the best climbing plants for permanent situations, as it is perfectly hardy, clinging to the sides of whatever it may be grown against by the rootlets it throws out all along the stems. In the autumn the dark green foliage assumes beautiful tints of orange, crimson, etc. Height, 50 to 100 feet.

Ampelopsis Veitchii.-(Boston Ivy).-Per pkt., 10c.

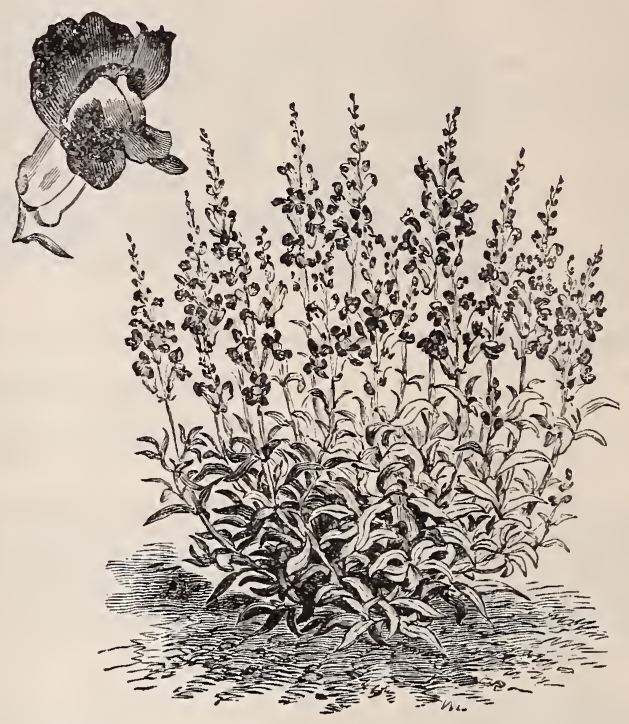

Antirrhinum Majus.

ANTIRRHINUM (Snapdragon).

The Antirrhinum is one of the finest border perennials. The Tom Thumb strain is admirably adapted for bedding, being very dwarf and free-flowering. Light soil, well enriched with manure, is most suitable for them. Sow in May, or in autumn. $5 c$.

Antirrhinum, Tall.-Mixed colors, per pkt., Antirrhinum, Dwarf.-Mixed colors, per pkt., $5 c$.

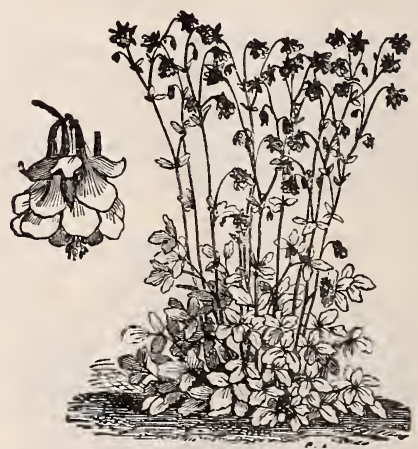

Aquilegia (Columbine).

AQUILEGIA (Columbine).

Colorado's Emblematic Flower.-Sow the seed early in spring; they do not always flower the first season, but, once established, they are perpetual. Flowers very early in the spring. Hardy perennial.

Aquilegia Hortensis.-Double; very fine mixed. Per plit., $10 \mathrm{c}$. 
Aquilegia Chrysantha.-(Golden-spurred Columbine).-A strong-growing, beautiful variety, attaining a height of four feet; flowers bright yellow. Per pkt., 10c.

\section{ASTERS.}

No family of plants bears such distinct marks of progress as the Aster, and none are more eagerly sought. The seed should be sown early in spring, and the young plants transplanted from one to two feet apart, according to the height and size.

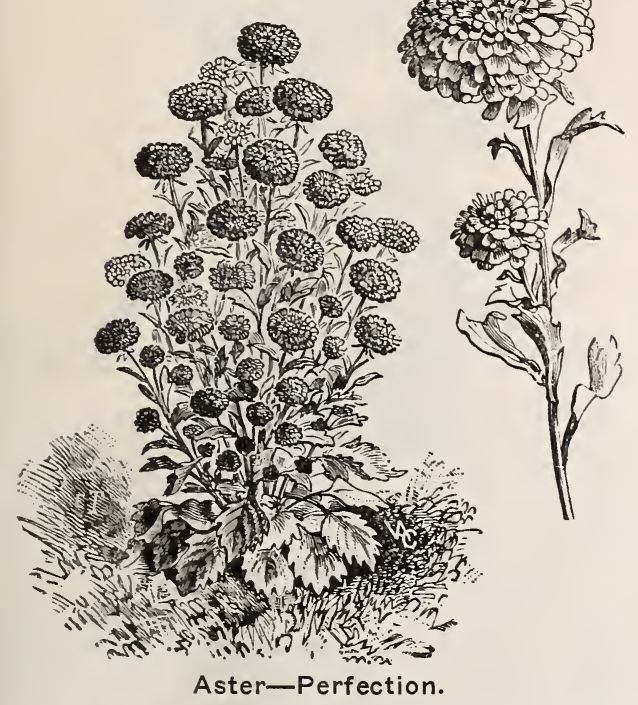

Aster, Quilled German.-Mixed; very double; of oval form; the petals have the appearance of quills or tubes; the outer ring is sometimes slightly reflexed, so as to form a sort of guard petal. Flowers large, brilliant and freely produced; $1 \frac{1 / 2}{2}$ to 2 feet high. Per pkt., $5 \mathrm{c}$.

Aster,French or Poeony Flowered.-Extra fine double; mixed. The flowers of this variety are remarkable for their perfect form and immense size, being four or five inches in diameter, oval in shape; 2 feet high. Per pkt., 10c.

Aster, Perfection.-(Truffaut.)-Mixed, double; the petals beautifully curved; one of the best in every respect. Per pkt., 10c.

Aster, Chrysanthemum.-Producing large, double flowers resembling Chrysanthemum, and valuable on account of profuse large flowering. Per pkt., 10c.

Aster, Shakespeare-Dwarf variety; six inches in height; novel shades of coloring; large, globular flowers; and very floriferous; each plant looks like a unique little bouquet set in the ground, so compact and crowded with blossoms. Pkt., 10c.

Aster, Comet or Branching.-A handsome and very distinct variety. With good culture, flowers of this type frequently measure four inches across, and in their fine form, large size and long stem, approach in beauty the fine chrysanthemum grown in the greenhouse during the late fall months. Per pkt., 10c.
Aster, Perennial.-Extra fine, mixed. Per pkt., 10c.

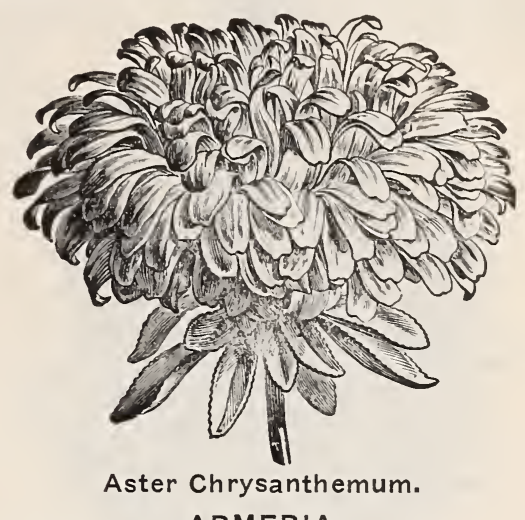

\section{ARMERIA.}

Armeria (Sea Pink).-These handsome plants are well adapted for ornamenting rock work and edging walks. Hardy perennial. Height, 6 inches.

Armeria Maritima.-Rosy pink. Per pkt., 5c.

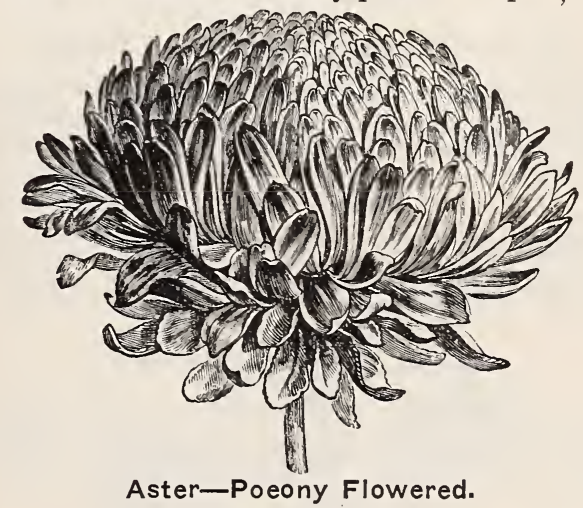

ASPERULA.

A flower finely adapted for bouquets, by reason of its shape, size and delicate color, a light blue or lavender. For button-hole bouquets nothing will be oftener in request than this, contrasting finely with scarlet, and remaining fresh a long time; in bloom from July until after severe frosts. Height, 9 inches. Hardy annual.

Asperula Azurea Setosa.-Per pkt., 5c.

BALSAMS (Ladies' Slipper, Touch-me-not.)

Magnificent conservatory or out-door plants, producing their gorgeous masses of beautiful, brilliant-colored flowers in the greatest profusion. The soil should be of the richest possible character. Tender annuals.

Balsam, Double Tall.-Fine mixed. A particularly fine strain of Balsam. Per pkt., $5 \mathrm{c}$.

Balsam, Dwarf Double.-Grows only 1 foot high. Pkt., 5c.

Balsam, Double Camellia Flowered.-As double as a Camellia, which it resembles, white, blotched with various colors. Per pkt., 10c. 


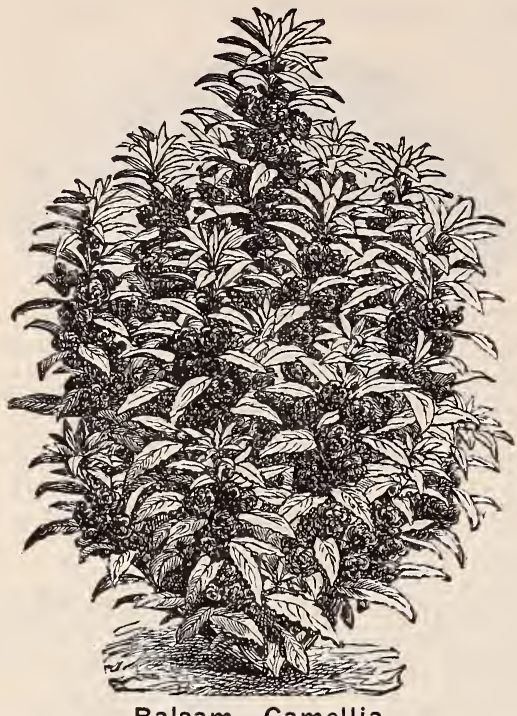

Balsam-Camellia.

BRACHYCOME (Swan River Daisy).

Produces an abundance of daisy-like flowers about one foot high. Fine for edgings, beds or rustic baskets. Finest mixed. Per pkt., 5c.

\section{BROWALLIA.}

Handsome plants, eighteen inches tall, with shining green foliage and bright blue and pure white flowers. Mixed. Per pkt., 5c.

\section{CACALIA (Tassel Flower).}

Small tassel-like blooms, often called Flora's Paint Brush, gracefully borne on long stems; useful for cutting; bright scarlet and yellow. Mixed. Per pkt., 5c.

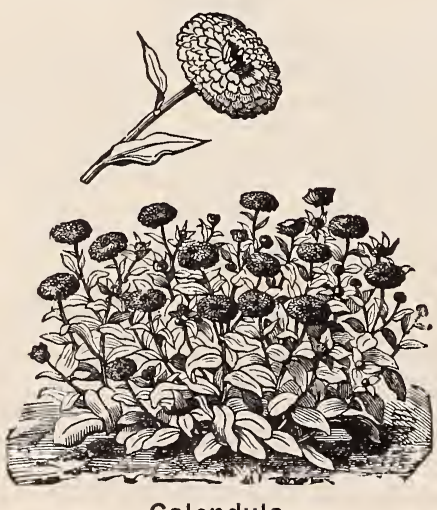

Calendula.

\section{CALENDULA (or Pot Marigold).}

This splendid variety has large double flow. ers beautifully imbricated, resembling in size and form the finest Aster. Each petal of pale straw color is regularly marked with stripes of bright, deep orange. Blooms profusely with a succession of flowers from July till frost. Fine mixed. Per pkt., 5c.

\section{CALLIRHOE.}

Pretty trailing plants, subdigitate leaves and prostrate habit, producing beautiful, large, silver-shaped blossoms, which resemble the portulaca in form, and are of a rich, purplish crimson color. Six inches high; hardy annual.

Callirhoe Involucrata -Purplish crimsor. Per pkt., 5c.

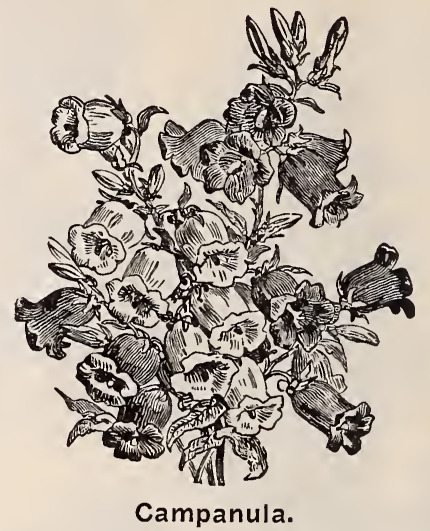

CAMPANULA (Canterbury Bells).

One of the best known plants grown in the garden. The hardy perennials, if sown early in good soil, will bloom early the next season. These are very fine for edgings and beds.

Campanula-Double mixed, per pkt., 5c.

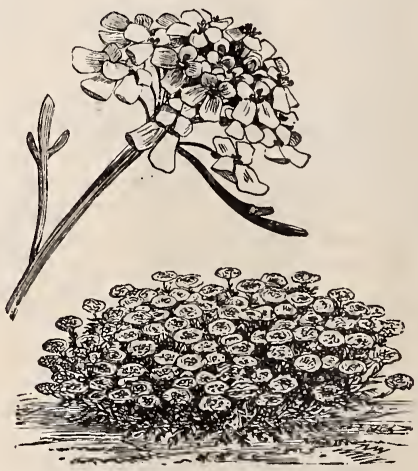

Candytuft.

CANDYTUFT.

One of the most popular hardy annuals, almost equally so as Sweet Alyssum. Like it, it is one of the easiest culture and grown for a variety of purposes almost all the year round.

Candytuft.-White. Per pkt., 5c.

Candytuft.-Mixed. Per pkt., 5c. $5 c$. 


\section{CANNAS (Indian Shot).}

Cannas, or Indian Shot, are very ornamental, and much employed in sub-tropical gardening for groups and masses. With rich soil and a sheltered situation they will flower freely through the summer and late into the autumn. Per pkt., 5c.

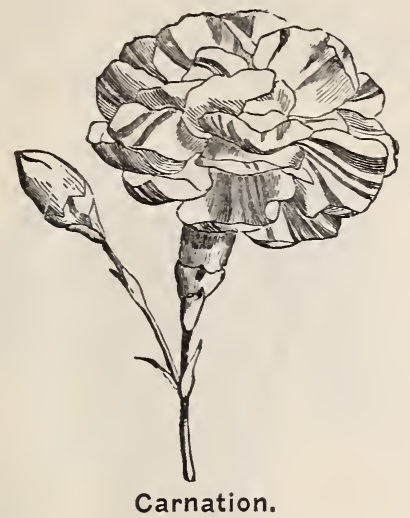

\section{CARNATION AND PICOTEE (Dianthus Caryo-} phyllus).

No flower can surpass in delicacy of marking, form or delicious fragrance the richly-hued Carnation. It has always been one of the most esteemed of the florist's collection, and there is no flower more esteemed for the garden. Sow under glass in greenhouse or hot-bed, and when of sufficient size transplant 2 feet apart each way.

Carnation Picotee.-Saved from a rich collection of sweet-scented sorts, large, double flowers. Finest mixed. Per pkt., 10c.

Marguerite Carnations. - The plants are branching, compact and neat in habit, standing well upright without any support. Per pkt., $10 \mathrm{c}$.

\section{CARDIOSPERMUM (Balloon Vine).}

$A$ rapid and graceful climber, sometimes called "Love in a Puff." Per pkt., 5c.

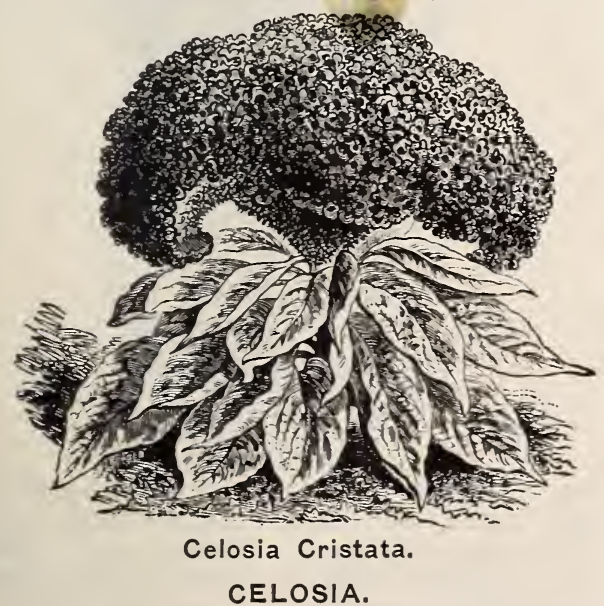

Annual plants of tropical origin, and one of the most satisfactory and showy plants for garden decoration, bearing in the greatest profusion spikes of beautiful, feather-like blossoms. In this class is included the well-known cockscomb.

Celosia Cristata.-Tall; extra fine mixed Cockscomb. Per pkt., 5c.

Celosia Cristata.-Dwarf mixed. Per pkt., 10c.

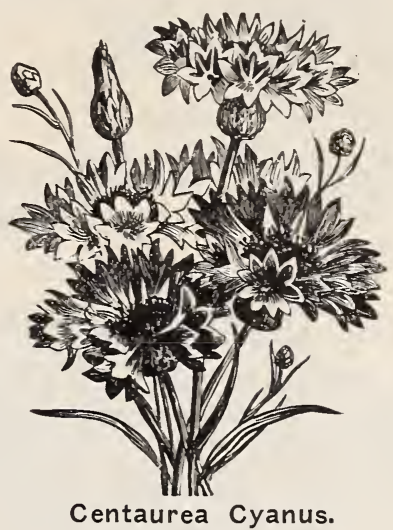

CENTAUREA.

An exceedingly interesting genus of plants, embracing annuals, biennials and perennials. Some of the varieties are magnificent foliage plants, while others are noted for their beautiful flowers. $5 \mathrm{c}$.

Centaurea Cyanus.-(Blue Bottle). Per pkt., Centaurea Cyanus.-Mixed. Per pkt., 5c.

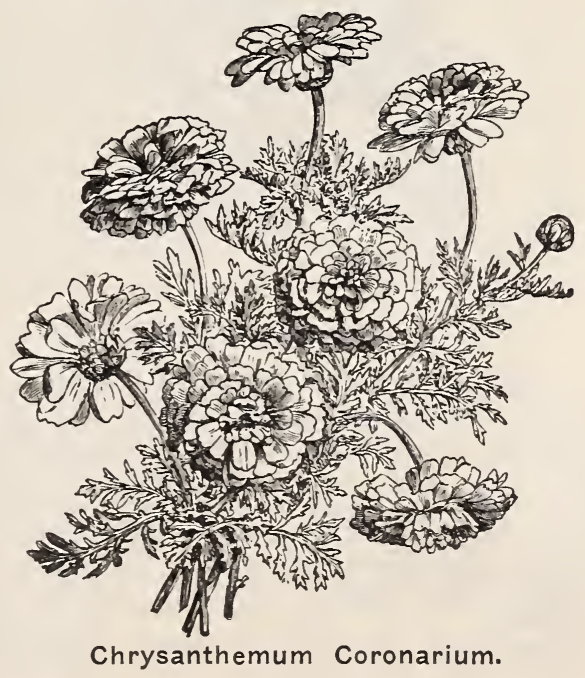

CHRYSANTHEMUM.

The great and growing demand for the annual varieties has brought Chrysanthemums into general favor. The leading sort now grown for cut-flowers at nearly all seasons is Burridgeanum, an exceedingly beautiful sort, the colors having the appearance of being laid on 
with a brush, and for this reason they are frequently called "Painted Daisies."

Crysanthemum Coronarium.-Double mixed. Per pkt., 5c.

\section{CLARKIA.}

A beautiful tribe of favorite plants, with pretty, cheerful-looking flowers, growing freely and blooming profusely under almost any circumstances. Hardy annuals. $5 \mathrm{c}$.

Clarkia Elegans.-Double mixed. Per pkt.,

\section{COBOEA.}

A fine summer climbing plant, quick growing and bearing large, bell-shaped, purple flowers. In sowing place the seed edgewise and cover lightly.

Coboea Scandens.-Purple; 20 feet. Per pkt., $10 \mathrm{c}$.

\section{COIX LACRYMA (Job's Tears).}

Curious ornamental grass from East Indies, with broad, corn-like leaves, and seeds of a light slate color, wonderfully lustrous. Valuable for the formation of winter bouquets in connection with everlasting flowers, and strings of hand. some beads are formed from the seeds. Plant in open ground, in hills three feet apart, four or five seeds in a hill, and cover half an inch deep. Hardy annuals; three feet high.

Coix Lacryma, Job's Tears. Pkt., 5c.

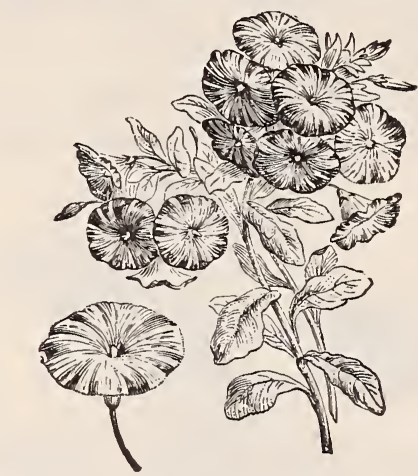

Convolvulus (Morning Glory).

CONVOLVULUS (Morning Glory).

All will recognize in this the most popular annual in cultivation, for in this tribe is in. cluded the well-known Morning Glory. The minor varieties are largely used and well suiteil for bedding; they attain an average height of one foot. Half-hardy annuals.

Convolvulus Major.-Very fine mixed. Per pkt., 5c.

Convolvulus Tricolor or Minor--Very fine dwarf mixed. Per pkt., 5c.

\section{COLORADO WILD CUCUMBER (Echinochys- tis Lobata).}

This wild cucumber is a native of Colorado and is without doubt the best and hardiest wild cucumber known. Very remarkable for the luxuriance and rapidity of its growth. Hardy annual; ten to twenty feet high.
Wild Cucumber--Very hardy, quick growing. Per pkt., 5c.

\section{COREOPSIS.}

Coreopsis.-A very showy annual or perennial plant, easily cultivated in ordinary soil. They are abundant in bloom, and of bright, attractive colors. C. lanceolata and C. grandiflora are fine for cutting. Per pkt., 5c.

Coreopsis Tinctoria, Mixed.-Per pkt., 5c.

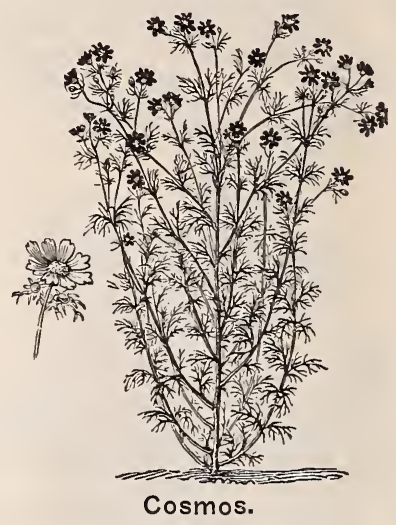

COSMOS HYBRIDUS.

Of very rapid growth and make large bushes, fully five feet high, which are a mass of elegant foliage until they bloom in August. From September until November each plant is covered with hundreds of showy blossoms, two inches in diameter, pure white, flesh color, charming light pink and deep rose in color, each with a bright yellow center.

All Colors Mixed.-Per pkt., 5c.

Pure White.-Large pure white flowers; extremely beautiful; very valuable to florists. Per pkt., 10c.

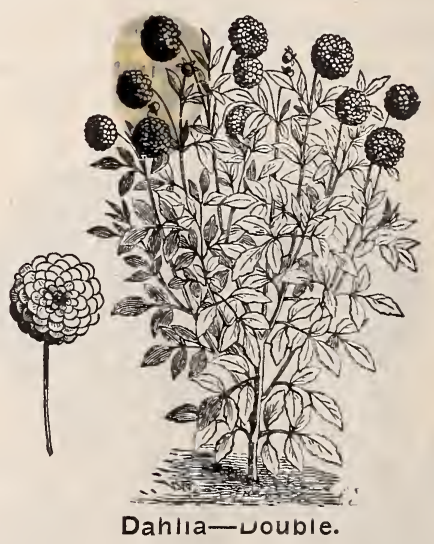

DAHLIA.

Good Dahlias can be grown from seed, and plants will bloom the first season from seeds. Any one who can raise a Zinnia or a Morning Glory can grow Dahlias from seeds. Start seed in house and transplant to open ground after frost is gone. 
Dahlia, Double.-Extra fine mixed, saved from choicest flowers. Per plit., 10c.

Dahlia, Dwarf.-Double extra fine, mixed, saved from choicest flowers. Plkt., 10c.

\section{DATURA.}

This is a majestic garden plant which is easily grown, and which furnishes an abundance of magnificent, large blossoms. It has a very tropical appearance. Per pkt., 5c.

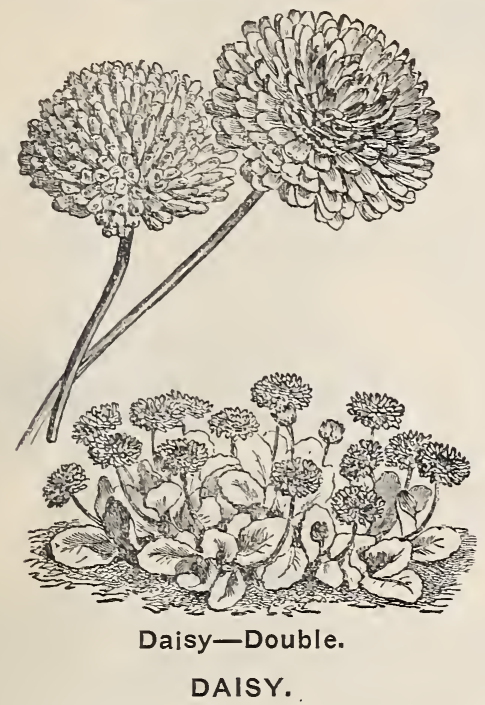

Charming little plants for edgings and borders. The flowers are quilled and flat-petaled, white, pink, red and variegated. Sow early in hot-bed, and, when large enough, transplant to rich, cool, partially shaded situation. Set the plants six inches apart. Roots can be divided at any time. Flowers are most abundant in spring. Tender perennial, six inches high.

Daisy.-Double mixed; very fine. Plkt., 10c.

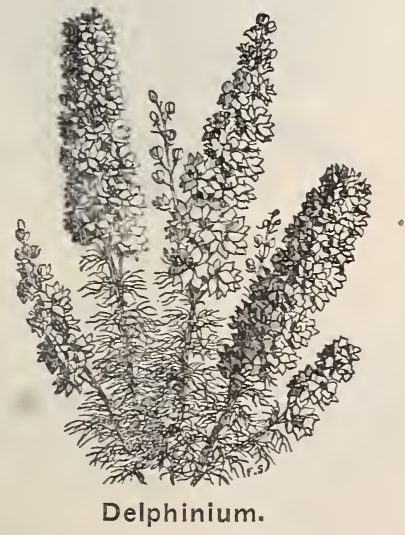

DELPHINIUM (Perennial Larkspur).

The Larkspur is one of the handsomest and most useful plants, and for large gardens is invaluable. The leaves are much divided and the flowers in terminal spikes. Easily propagated by seed or by dividing the roots; delights in a deep, rich soil, and should be sown in August or September. Per pkt., 5c.

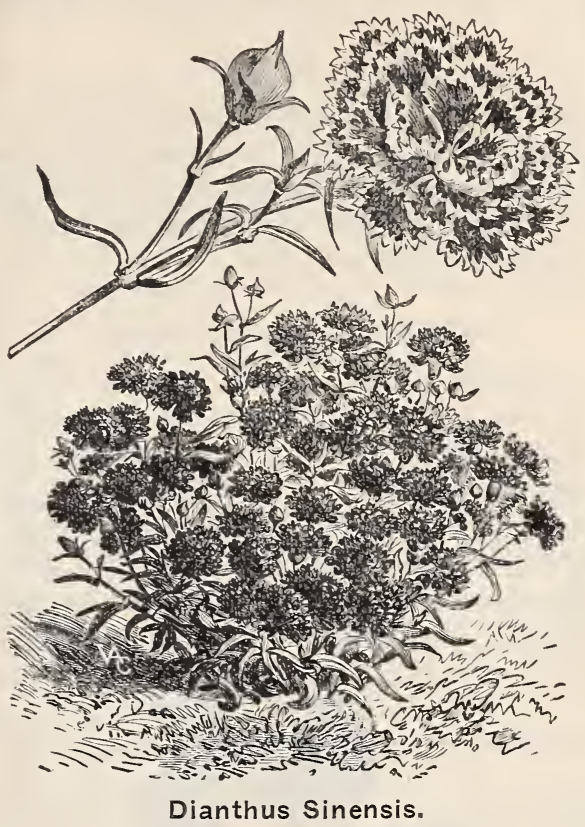

DIANTHUS SINENSIS (Indian Pink).

This magnificent tribe is one of the most satisfactory that can be raised trom seed. Dianthus Sinensis and varieties are known as Indian Pinks, perhaps one of the most beautiful classes of plants existing.

Dianthus Chinese.-Double; Extra fine mixed. A mixture of the most beautiful double sorts, and of every desirable shade or peculiar marking. This will give a bed of beautiful flowers and scarcely two plants will be alike. Plí., $5 \mathrm{c}$.

\section{DIGITALIS (Fox Glove).}

Handsome, ornamental plants, of stately growth and varied colors. Hardy jerennials.

Digitalis Gloxinoides.-Very fine mixed; three feet. Per plit., 5c.

\section{DOLICHOS (Hyacinth Bean).}

Beautiful climbing plants of free growth and flowering in character; ten feet. Tender annuals.

Dolichos Lablab.-Mixed. Per plit., 5c.

\section{ESCHSCHOLTZIA (California Poppy).}

Very profuse blooming plants of extremely rich and beautiful colors; one foot. Hardy annuals.

Eschscholtzia Californica.-Very fine mixed. Pkt., 5c.

Eschscholtzia Californica-Double--Very fine mixed. Plit., 10c. 


\section{FORGET-ME-NOT (Myosotis).}

The different varieties of this popular plant are very beautiful and too well known to need mentioning. They succeed best in moist situations.

Myosotis Alpestris.-Large flowering; mixed. Forget-Me-Not. Per pkt., 10c.

Myosotis, Dwarf, Blue-A charming dwarf Forget-Me-Not, under eight inches in height, free growth, thriving well in either sunny or shady spots. Per pht., 10c.

\section{GERANIUM (Pelargonium).}

No garden seems complete without a bed of them, and in every collection of conservatory or parlor plants we are sure to find the Geranium. Propagation by seed is the only sure way to obtain superior varieties. Sow in March, in gentle heat, in well-drained pots.

Geranium Pelargonium Zonale and Inquinans.-Per pkt., 10c.

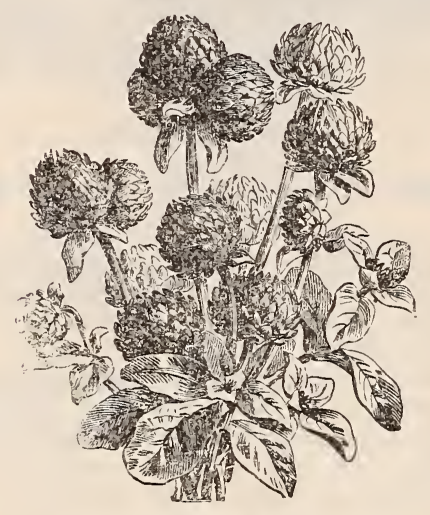

Giobe-Amaranth.

\section{GLOBE-AMARANTH (Gomphrena Bachelors' Buttons).}

A desirable everlasting, valuable for its handsome globular heads of flowers, which if cut when matured, will retain their beauty for years. Seeds germinate slowly; start in hotbed, or soak in warm water to soften the wooly husk. Tender annuals; two feet high.

Globe-Amaranth.-Mixed; two feet high. Per pkt., 5c.

\section{GODETIA.}

Of hardy annuals none are more beautiful than these; they are of a dwarf habit of growth, the flowers are of handsome shape, in the most brilliant as well as delicate colors and are produced in marvelous profusion. They are of the easiest possible culture; any child can make them grow. Per plit., 5c.

\section{GOURDS (Cucurbita).}

A tribe of climbers with curiously-shaped fruit in various colors. Being of rapid growth, they are fine to cover old fences, trellises, etc. Do not plant the seed until all danger of frost is over, and select rich, mellow ground. Tender annual climbers; ten to twenty feet high. $5 \mathrm{c}$.

Gourds.-Ornamental, small mixed. Per pkt.,

GOURDS.-Ornamental, large mixed. Per plkt., $5 \mathrm{c}$.

\section{HELICHRYSUM.}

One of the best of the immortelles; good shape, size, and a variety of desirable colorsyellow, sulphur, cream, white, pink, rose, red and crimson. In bloom from July till destroyed by, frosts; height eighteen inches. Hardy annual, Helichrysum, Double Mixed, per pkt., $5 c$.

\section{HELIOTROPE.}

Well known, deliciously fragrant plants, excellent for bedding purposes or pot culture. Half-hardy perennial.

Heliotropium Grandiflora.-Finest mixed; eighteen inches. Per pkt., 10c.

\section{HIBISCUS.}

A showy, hardy annual, cream color with rich brown color; height, two feet. $5 \mathrm{c}$.

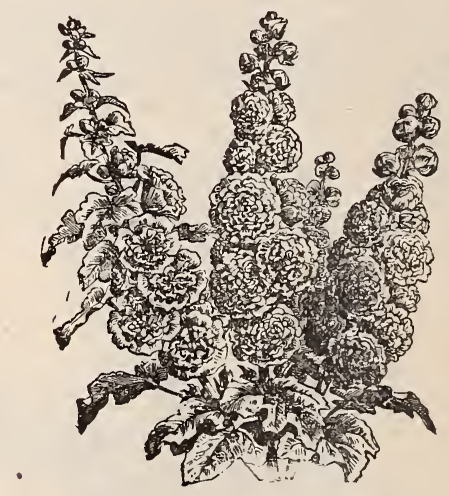

Hollyhock.

HOLLYHOCK.

The flowers are as double as the rose, of many shades of color, from deep yellow, red and purple, to pure white. Plant the seed in June or July, in open ground, and in the autumn, when the plants have made five leaves, transplant to permanent position, three feet apart. The following summer they will bloom. Each plant should be supported by a stake. Hardy perennial; five feet high.

Hollyhock, Double.-Extra choice, double, finest mixed. Per pkt., 10c. 


\section{ICE PLANT.}

A very singular dwarf, trailing plant, much used for garnishing. 'The leaves and stems are covered with crystalline globules, giving it the appearance of being covered with ice. Halfhardy annuals.

Ice Plant.-Per pkt., 5c.

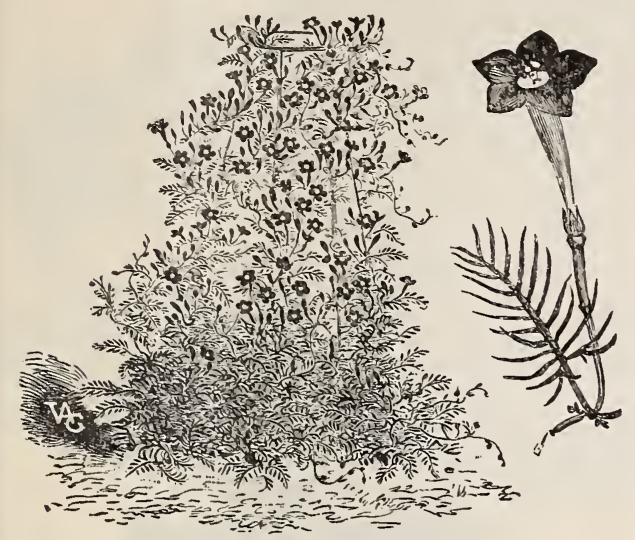

Ipomoea Quamoclit.

IPOMOEA.

This beautiful genus, like the Convolvulus, to which it is closely allied, is most useful for covering trellises, arbors or unsightly objects. Tender annuals.

Ipomoea Quamoclit.-(Cypress Vine).-Scarlet. Per pkt., $5 \mathrm{c}$.

Ipomoea.-Mixed; large and fragrant; ten feet. Per pkt., 5c.

\section{LANTANA.}

The varieties of the Lantana are almost numberless. The flowers are borne in Verbenalike heads, embracing every shade of pink, purple, orange and white.

Lantana.-Finest French Hybrid mixed, all colors. Per pkt., 5c.

\section{LARKSPUR.}

The Larlispur is one of the handsomest and most useful of plants, and for large gardens is invaluable. The brilliancy of some of the colors is unsurpassed. Easily propagated by seed or by dividing the roots; delights in a deep, rich soil, and should be sown in August or September.

Larkspur, Dwarf German Rocket.-Double extra fine mixed. Per pkt., 5c.

Larkspur, Tall German Rocket.-Double, finest mixed. Per plit., 5c.

\section{LINUM (Crimson Flax).}

Linum Grandiflorum Rubrum.-One of the most beautiful annuals known; valuable for bedding. Per plkt., 5c.

\section{LOBELIA.}

A most elegant and useful genus of plants of easy culture, and well adapted for bedding, edging, pots or rockeries. They are applied as universally in general summer gardens as Scarlet Geraniums, to beds of which they form a neat and effective edging. Seeds should be covered lightly.

Lobelia Erinus.-Mixed. Per plit., 10c.

\section{MARIGOLD.}

The Marigold has been an inhabitant of the flower garden from time immemorial, and where a rich display of bloom is desired, is almost indispensable. The French varieties are tall, usually two feet or more, while the African are more dwarf, of most perfect form and gorgeous beauty; all are desirable. Half-hardy annual; bloom till frost.

Marigold, African, Double Dwarf-Very fine mixed. Per pkt., 5c.

Marigold, French, Tall.-Very tine mixed. Per pkt., 5c.

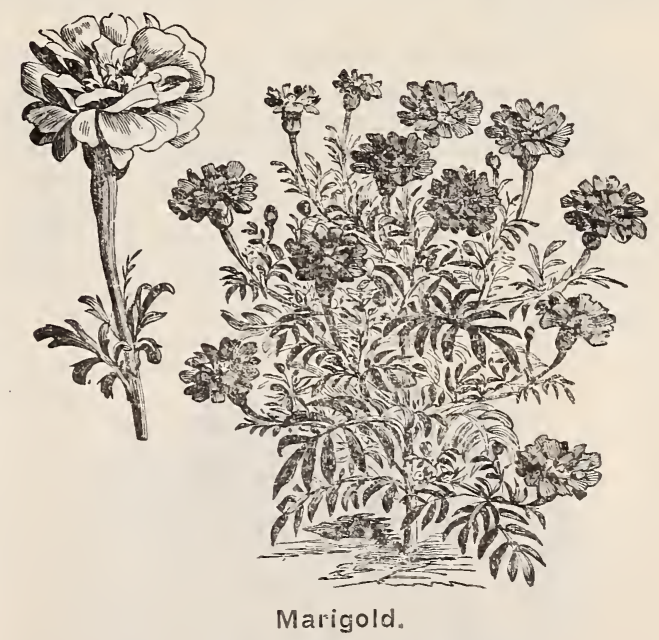

MARVEL OF PERU, OP FOUR O'CLOCK.

Old-fashioned, but none the less beautiful on that account. The plants are large and require four feet space; make a pretty hedge. Some of the varieties have beautifully variegated leaves. Will grow in any common garden soil, from seed sown in open ground. Hardy annual, two feet high.

Marvel of Peru.-Hybrid, finest mixed. Per pkt., $5 \mathrm{c}$. 


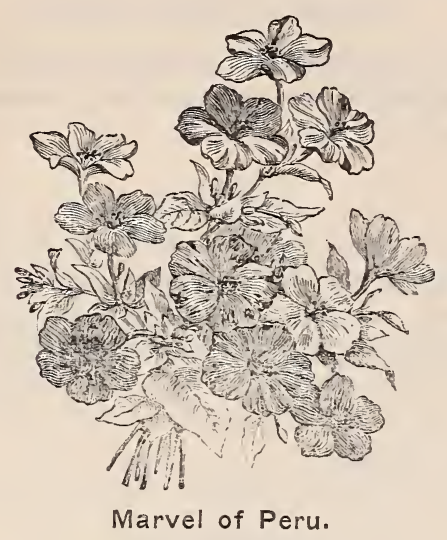

MESEMBRYANTHEMUM.

Dwarf growing plant of great beauty, well suited for edging and covering rock work, producing their star-like flowers in great abundance the whole summer. Half-hardy annuals.

Mesembryanthemum Tricolor.-(Tax Pink). - Mixed colors; six inches. Pkt., 10c.

\section{MIMULUS.}

Strikingly handsome flower of easiest cultivation. Perennials in the greenhouse; annuals in the open air.

Mimulus Moschatus.-(Musk Plant).-Cultivated on account of the musky odor of the plant. Needs rich soil and plenty of moisture. Per pkt., 10c.

\section{MIMOSA OR SENSITIVE PLANT.}

An interesting and curious plant; with globular heads of pink flowers, well known for the extreme irritability of its leaves and footstalks, which close and droop at the slightest touch, or in cloudy, damp weather, and during the night. Start in hot-beds, in pots and transplant into a warm situation, six inches apart. Tender annual; two feet high.

Mimosa Pudica.-Per pkt., 5̌c.

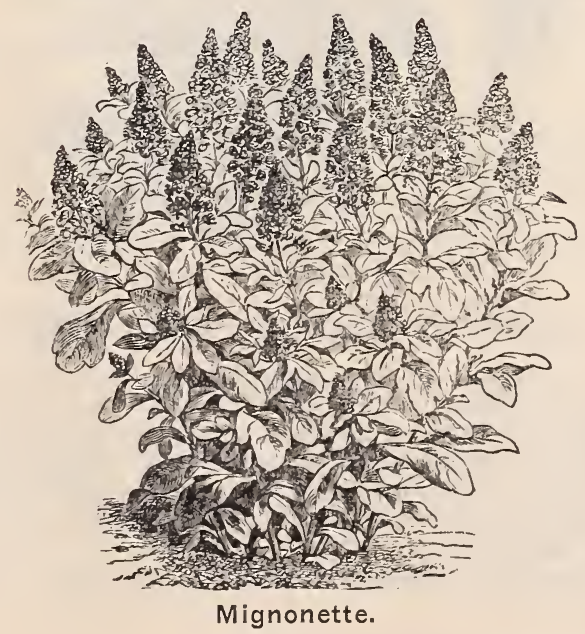

\section{MIGNONETTE.}

A well-known hardy annual, producing dense, semi-globular heads of exceedingly fragrant flowers, borne on spikes three to six inches long. It is in bloom nearly the whole season, and the perfume is so fragrant that the whole atmosphere around is perfumed.

Reseda Odorata.-Large flowering variety. Per pkt., $5 \mathrm{c}$.

Mignonette, Dwarf.-Machet, dwarf, French variety, with broad spikes of very fragrant red flowers. Per pkt., 10c.

Large Flowering Golden Queen.-(Reseda Ameliorata).-Quite distinct from the old large flowering variety; its foliage and flowers are much larger and has a charming goldenyellow tint; deliciously fragrant. Per pkt., 10c.

\section{NASTURTIUM.}

These will always be valuable summer flowering plants. They flower better, however, in a poor, rocky soil, as a rich one has a tendency to make them "run to leaf." "The Tom Thumb" varieties are splendid bedding sorts. Hardy annuals.

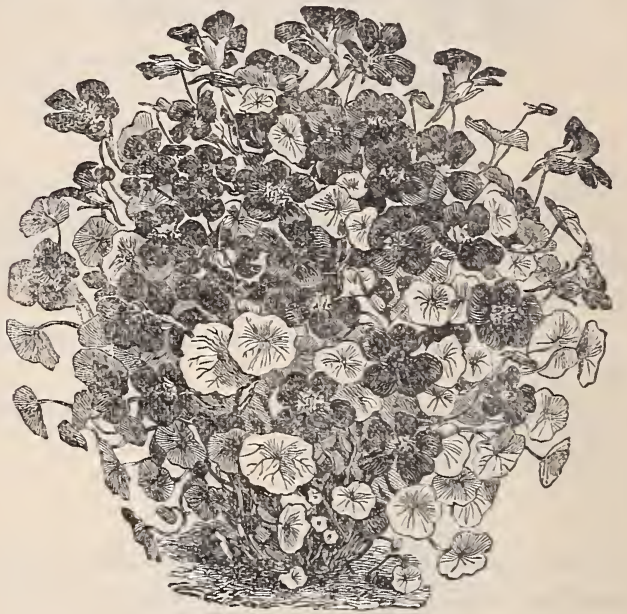

Nasturtium.

Nasturtium, Canariense, or Canary Bird Flower.-Per plit., $10 \mathrm{c}$.

Nasturtium, Dwarf or Tom Thumb.-Fine mixed. Pkt., 5c.

Nasturtium.-Tall, finest mixed. Pkt., 5c.

\section{NICOTIANA.}

A handsome genus of garden plants of the tobacco family, which are noted for freedom and fragrance of their bloom. Half hardy annual, 3 feet hign.

Nicotiana.-Large flowering; purple. Per package, $5 \mathrm{c}$.

\section{NIGELLA.}

Curious and interesting free-flowering plant of the easiest culture, growing in any garden soil. Hardy annuals.

Nigella Damascena.-(Devil in a Bush).Double mixed. Pkt., 5c. 
HEARTEASE (Pansy).

These lovely flowers are favorites with all, not only for the brilliancy and variety of their colors, but for the durability of their bloom. Seed may be sown in open ground in spring or summer, or in hot-beds early in spring. The ground can not be too rich; coolness and moisture are necessary. Transplant them when an inch high. Hardy biennial; four inches high.

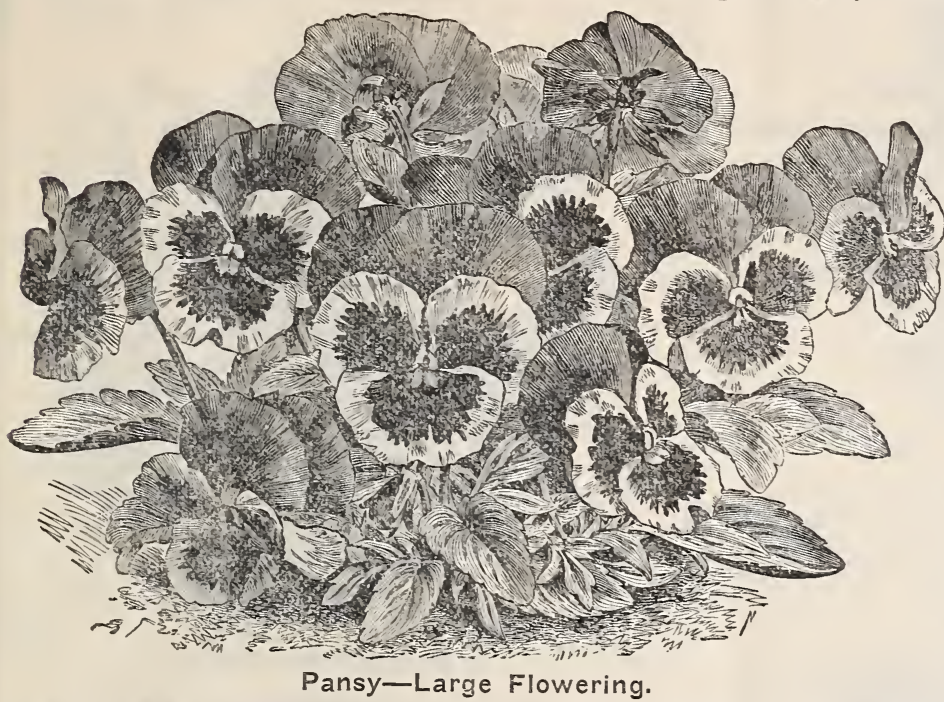

Pansy, King of the Blacks.-Coal black. Per pkt., 5c.

Pansy, Purple, Gold Edge.Plit., 5c.

Pansy, Sky Blue.-Per pkt., 5c. Pansy, Pure White.-Per plit., 5c.

Pansy.-Fine mixture of all colors. Plkt., $5 \mathrm{c}$.

Pansy, Pride of the West.-A beautiful strain of the choicest pansies, and a very valuable addition to the large-flowering kinds, and admired by all for their striking beauty. Plkt., 10c.

Trimardeau.-Very large flowered, mixed. An entirely distinct and beautiful race, with flowers of the richest and most varied shades of color. Plants of vigorous and compact growth, and the flowers, which possess unusual substance and consistency, are each marked with three large blotches or spots. Per pkt., 15c.

La Parisienne.-An entirely new strain of pansy; very large; flowering of the most exquisite shades of color, as large as the Giant Trimardeau, but more varied in color, and the blotches more distinct. Per plit., 15c.

Watkins Finest Mixed.-Unrivaled for diversity of coloring and marking. This mixture is made up of the finest and largest varieties grown by Pansy specialists in Europe and America. In the making up of this mixture, expense is not regarded. Our aim is to possess the finest of Pansies obtainable. Per pkt., 25c.

\section{SWEET PEAS.}

Very beautiful, fragrant, re-flowering, climbing plants, continuing in bloom all summer. Sup. ported by common pea sticks they form admirable screens for protecting more tender plants or excluding unsightly objects. Valuable for trailing on trellis work, covering rough fences, etc.; six feet high. Hardy annuals.

We have the finest stock of Sweet Peas that has ever come to Colorado, grown by the best and most reliable growers in the United States and Eu. rope.

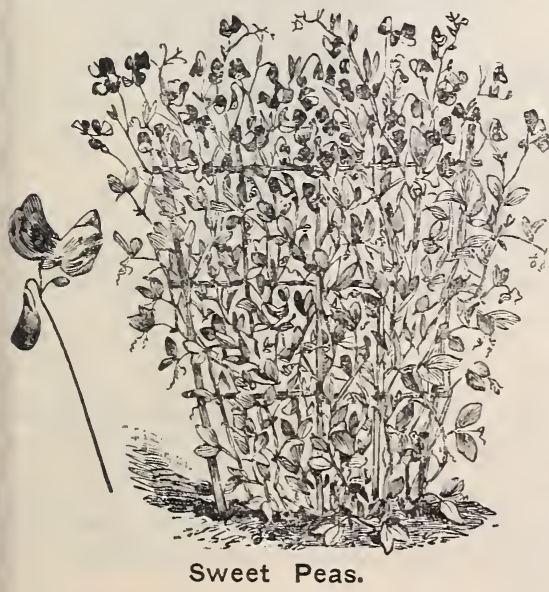

Collection of 24 Different Shades. FKT. $10 z .20 z$. Admiration.-Pink Mauve................... $5 \quad 10 \quad 15$ America.-Bright red and white striped....... $5 \quad 10 \quad 15$ Apple Blossom.-Crimson, pink and white shaded $5 \quad 10 \quad 15$ Aurora.-Orange, rose and white striped........ $5 \quad 10 \quad 15$ Blanche Burpee.-A splendid pure white.......5 51015 Captivation.-Magenta ...................... $5 \quad 10 \quad 15$ Coccinea.-Pure Cerise (cherry red)........... $5 \quad 1015$

Coquette.-Primrose and very light purple....... $5 \quad \begin{array}{lll}10 & 15\end{array}$

Countess of Codogan.-Lilac and purple........ $5 \quad 10 \quad 15$

Dorothy Tennant.-Rose purple.............. 5 $10 \quad 15$

Duke of Sutherland.-Dark violet and purple... . 5, $10 \quad 15$

Emily Henderson.-A persistert bloomer........ $5 \quad 10 \quad 15$

Fascination.-Tints of blue and lilac.......... $5 \quad 10 \quad 15$

Golden Rose.-Light primrose, striped light pink. $5 \quad 10 \quad 15$

Gray Friar.-Heliotrope, striped light pink....... $5 \quad \begin{array}{lll}10 & 15\end{array}$

Hon. F. Bouverie.-Deep pink shading to light pink $5 \quad 10 \quad 15$ Josephine White.-Very early white............ $5 \quad 1015$ Miss Wilmott.-Large orange pink............5 $510 \quad 15$

Navy Blue.-Indigo blue and violet............. $5 \quad 1015$

Prince of Wales.-Rose crimson.............. 5 $10 \quad 15$

Queen Victoria.—Light primrose.............. 51015

Shahzada.-Dark maroon and violet............ $5 \quad 10 \quad 15$

Stella Morse.-Buff tinted pink............. 5 $10 \quad 15$

Venus.-Delicate blending, pink, salmon, rose buff $5 \quad 1015$

(CONTINUED NEXT PAGE) 


\section{SWEET PEAS.-(Continued.)}

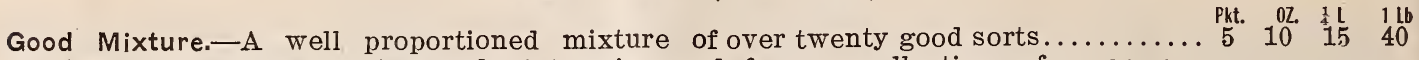
Trial Ground Mixture.-This grand mixture is saved from a collection of over one

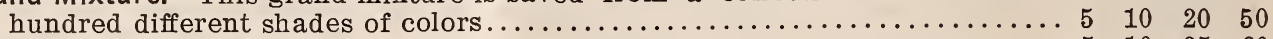

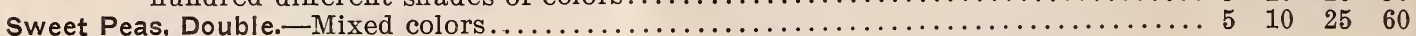

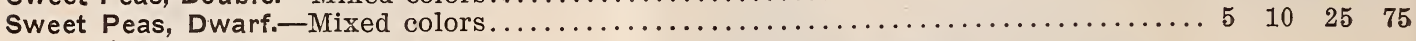

PASSIFLORA (Passion Flower).

A most interesting and well-known order of climbers, bearing singularly beautiful flowers. They are the pride of South America and West Indies, where the woods are filled with the species, which climb about from tree to tree, bearing flowers of striking beauty.

Passiflora Coerulea.-Per pkt., 5c.

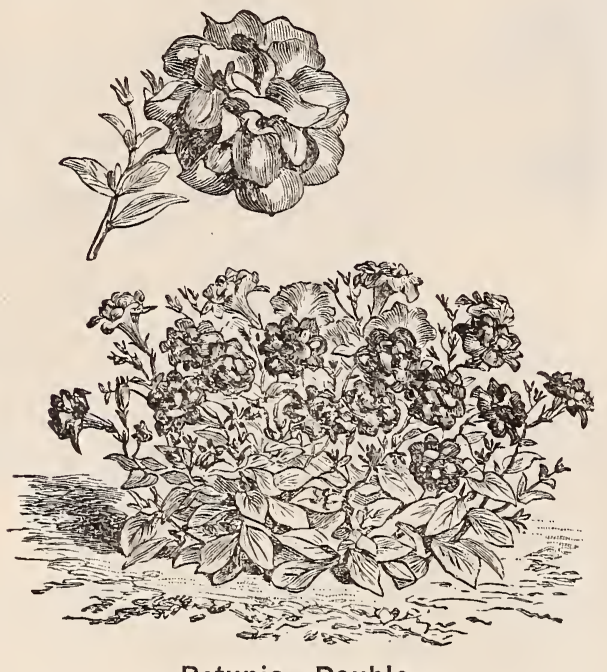

Petunia-Double.

\section{PETUNIA.}

Most valuable plants, succeeding well almost anywhere. They are particularly showy in beds or masses, and are universal favorites on account of their richness of color, fragrance and continued blooming.

Petunia Hybrid.-Extra fine mixed. Per plkt., $5 \mathrm{c}$.

Petunia Hybrid, Double.-Large flowering striped, mixed; very fine strain, with large, perfect flower. Per pkt., 15c.

\section{PHLOX DRUMMONDII.}

Phlox Drummondii is one of the very finest of annual plants, and stands almost unrivaled for profusion of color. The seeds can be planted in open ground in autumn or spring, or plants may be started in a hot-bed and transplanted. Give good, rich ground, and set plant.s six inches apart each way. Hardy annual; one foot high.

Phlox Drummondii, Large Flowering. - Fine mixed. Per pkt., 5c.

Phlox Drummondii Dwarf.-Fine mixed. Per pkt., $10 \mathrm{c}$.

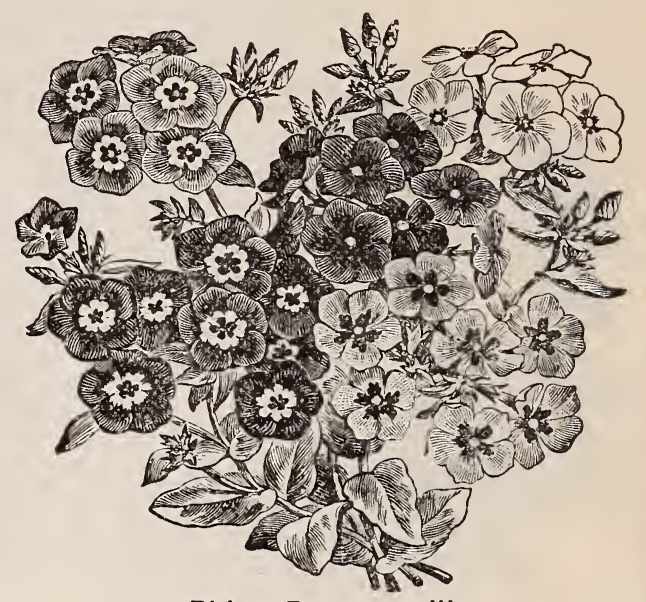

Phlox Drummondii.

POPPY.

Hardy annual of quick growth and producing large, brilliant colored flowers, growing freely in any garden. Produces a fine effect in clumps or beds.

Poppy, Double Carnation.-Flowered, mixed, Pkt., 5c.

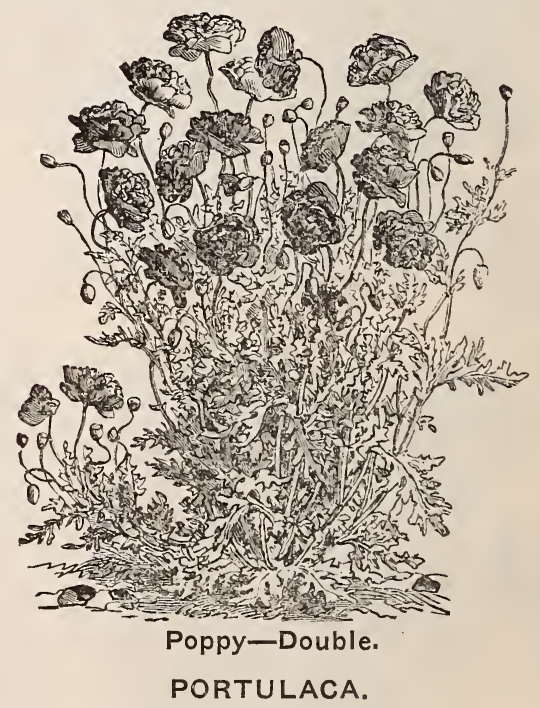

Beautiful and popular hardy annuals of the easiest culture, luxuriating in an exposed, sunny situation, and producing throughout the summer their flowers of almost every hue in the greatest profusion. The double Portulaca is one of the finest annuals in cultivation. Six inches high. 


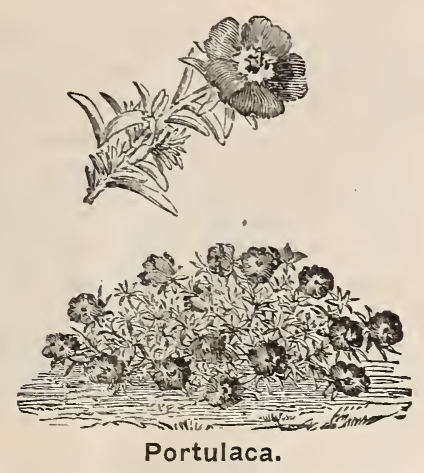

Portulaca, Fine Mixed.-Per pkt., 5c.

Portulaca, Grandiflora Flore Pleno.-Fine double, mixed. Per pkt., 10c.

PRIMULA SINENSIS (Chinese Primrose).

Sow the seeds in shallow boxes filled with good, rich soil, dusting a little fine earth over them; if covered too deeply, or if the seed be wet and allowed to dry again, they will not germinate. Transplant into pots and they will be ready for winter blooming in the drawing room. Tender perennials, six to nine inches high.

Primula Elatior.-Splendid mixed. Pkt., 10c.

\section{RICINUS (Castor Oil Bean).}

Tall growing plants of tropical origin, whose luxuriant foliage renders them exceedingly ornamental and desirable. Half-hardy annuals.

Ricinus Major.-Splendid ornamental plant; eight feet high; mixed. Per plit., $5 \mathrm{c}$.

Ricinus, Dwarf Mixed.-Per pkt., $5 \mathrm{c}$.

\section{SALPIGLOSSIS.}

Highly ornamental autumn flowering plants, with beautifully veined and tinted, funnelshaped flowers. A very choice annual, two and one-half feet. Fine mixture of large flowering varieties.

Salpiglossis Hybrid.-Extra fine mixed, per pkt., 5 c.

\section{SCHIZANTHUS.}

This annual should be more widely cultivated. Flowers different shades of blue, curiously cut and delicately spotted; laced with crimson, white; yellow, etc. Adapted for garden and indoor culture. Excellent for bouquets. Height 18 inches.

Schizanthus Pinnatus.-Mixed colors. Per pkt., $5 \mathrm{c}$.

\section{SMILAX.}

Sow in shallow boxes in light soil at any season of the year. Press the seed evenly into the soil, and then cover to the depth of one-sixteenth of an inch. The seed often germinate slowly, lying sometimes three or four months before it all comes up. When fit to handle, transplant into shallow boxes or small pots.

Smilax.-Per pkt., $10 \mathrm{c}$.

\section{STOCKS (Gilliflower).}

To have them bloom early, start in hot-bed and transplant when small into pots, and turn out in June to open border. They will blossom late in the season if planted in open ground. Hardy annual; one foot high.

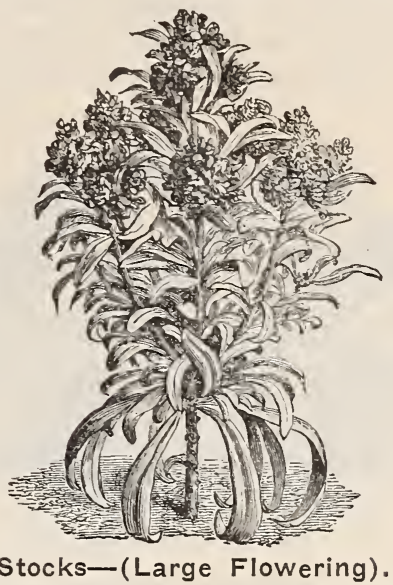

Stocks, German.-Ten weeks-Double; very fine, mixed. Pkt., 5c.

Stocks, German.-Ten weeks.-Large flowering, mixed. Pkt., $10 \mathrm{c}$.

\section{SWEET SULTAN.}

A handsome annual with fragrant flowers borne on long slender stems. Their fragrance and habit of growth adapt them finely for bouquets. In bloom from July to October; height two feet; mixed colors. Pkt., 5c.

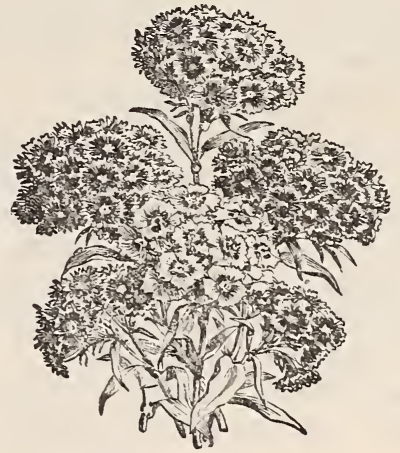

Sweet William.

SWEET WILLIAM.

For display in the garden, Sweet William is unsurpassed. The seed can be planted very early in the spring in open ground, and will blossom the following autumn, or it can be sown in August and will make fine blooming plants for spring. The plants will bloom several years, but young plants bloom better, and seeds should be sown every year. IHardy perennial; one and a half feet high.

Sweet William.-Double mixed. Pkt., 10c.

Sweet William.-Single mixed. Pkt. 5c.

\section{VERBENA.}

Flowers perfectly well from seed sown in spring. If started in the house in pots in winter they will be in bloom sooner, but if sown 
in open ground in May they will bloom in August. Each plant will require a space of four feet. Tender perennial trailer; one foot high.

Verbena Hybrid.-Extra choice, mixed. Per pkt., $10 \mathrm{c}$.

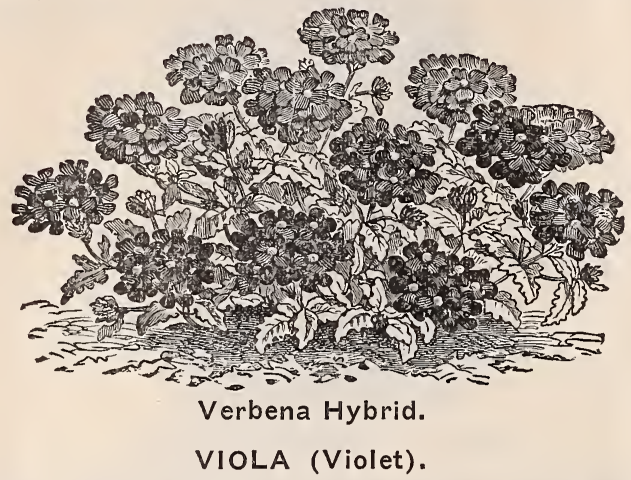

The violet should not be wanting in any garden, on account of its fragrance and early appearance. A single flower will perfume a whole room. Succeeds best in a shady, sheltered place. The violet is an emblem of faithfulness. Hardy perennial; four inches high.

Sweet Scented Blue.-Per pkt., 10c.

\section{VIRGINIA STOCKS.}

Very pretty, free flowering plants, succeed in any soil; mixed colors. Per pkt., 5c.

\section{WALLFLOWER.}

A well-known plant, much esteemed for its fragrance. Sow seed early in hot-bed, and when the plants are small put them out into pots and sink the pots in the earth. On approach of cold weather remove the pots to the house, and they will bloom all winter. Tender perennial. Eighteen inches high.

Wallflo'wer.-Double, mixed. Pkt., 10c.

Wallflower.-Single, mixed. Pkt., 5c.

\section{WHITLAVIA.}

An elegant annual with delicate foliage and drooping clusters of rich, dark blue and white bell-shaped flowers. Is fine for baskets and vases; for piazza decoration is one of the best, flourishing best in partly shaded situations; height one foot.

Whitlavia Grandiflora.-Per pkt., $5 \mathrm{c}$.

"WILD FLOWER GARDEN" (or Mixture of all Kinds of Flower Seeds).

Any one who has planted and cultivated flowers, in neatly laid out beds and borders, is aware of the labor and constant attention required to produce the desired effect. To those who can not give it this care "The Wild Flower
Garden" presents a substitute which, for its unusual and varied effects, cheapness and the small amount of labor necessary for its construction, has no equal. The seeds we offer for the "Wild Flower Garden" are a mixture of over 150 different varieties, and being mixou can be offered at a much less price than when sold in separate packets. No one, not having such a bed, can form an idea of its beauty, the different seasons of bloom insuring something new almost every day. Large packet, 10c; $1 / 4$ oz., 15c.; I/2 oz., $25 \mathrm{c}$.

\section{WILD CUCUMBER.}

Ornamental climbing cucumbers with curious fruit, remarkable for their luxuriance and rapidity of their growth. Height 15 feet. Halfhardy annual.

Echinochystis Lobata.-Mixed. Pkt., 5c; oz., $15 \mathrm{c} ; \mathrm{r} / 4 \mathrm{lb} ., 40 \mathrm{c}$.

\section{XERANTHEMUM.}

A popular flower of the immortelle class. Blooming freely in common soil. Plant is of compact habit with flowers borne on strong stems. Colors, white, purple, yellow and ligt: blue. Hardy annual; height one foot. Pkt., 10c.

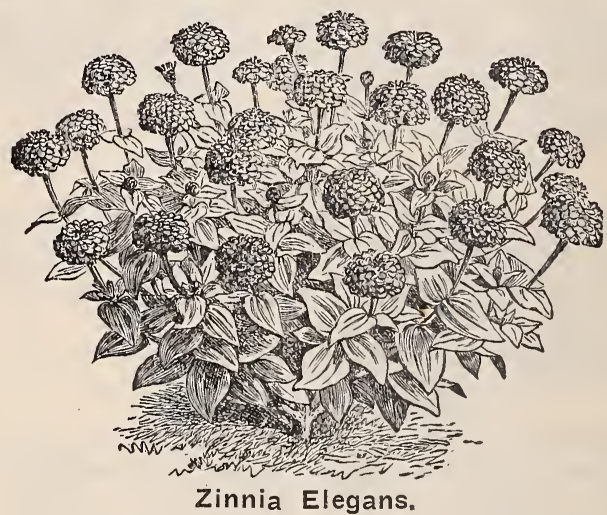

ZINNIA ELEGANS (Youth and Old Age).

A very showy plant with large double flowers, which, when fully expanded, form hemispherical heads, become densely imbricated, and might easily be mistaken for dwarf Dahlias. The colors run through all the shades of carmine, lilac, scarlet, purple, crimson, yellow, to pure white. Sow the seed early in the spring, in open ground, and transplant to one and onehalf feet apart, in good rich soil. Half-hardy annual; one and one-half feet high.

Zinnia Elegans.-Double, mixed; saved from selected flowers. Per pkt., 5c.

Zinnia Elegans.-Double, large flowering, mixed. Pkt., 5c. 
FLOWER BULBS FOR FALL PLANTING. Each. Per. doz.

Calla, white............... $\$ 15 \mathrm{c}$

Roman Hyacinth, white..........10 75

Single Hyacinth, mixed colors....10 $\quad 1.00$

Double Hyacinth, mixed colors....10 1.00

Single Tulips, mixed colors.....05 .35

Double Tulips, mixed colors.....05 .35

Crocus, mixed colors..........02 .20

Lily of the Valley.............05 .35

Bermuda Easter Lily..........20 2.00

Chinese Sacred Lily............15 1.50

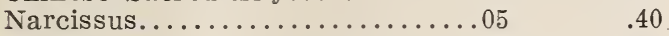

Freesia .................... $05 \quad 40$

Oxalis ................... $\quad .40$

Snowdrops, single ..............02 .20

Snowdrops, double ...........03 $\quad .30$

Hyacinth, glasses ............20
FLOWER BULBS FOR SPRING PLANTING. Each. Per. doz.

Gladiolii, mixed colors.........05c $\$ .40$

Cannas, unnamed..............15 1.50

Tuberoses ...................... 405

Madeira Vines ..................05 35

Caladium Esculentum ........20 2.25

Dahlia, mixed colors..........10 1.00

Dahlia, named ..............15 1.50

Lilium Auratum ............25 2.50

Paeonia, red, white and crimson..15 1.50

Tuberous Begonias, single, mixed.15 1.50

Tuberous Begonias, double, mixed.20 2.25

Amaryllis Formosissima.......15 1.50

Funkia, or Day Lily............15 1.50

$2.00 \quad$ Bleeding Heart..............25 2.50

\section{HOW TO MAKE A LAWN.}

When practicable, the soil of the proposed lawn should be thoroughly prepared in the fall. After the necessary grading has been accomplished and the general formation of the surface established, let it all be again thoroughly plowed, harrowed and well pulverized, and finally raked to a smooth, even surface-as smooth as possible, and firm; not only that, but alike compact in every spot, to prevent unequal settling. This may be accomplished by treading down and again filling up to grade where necessary. Scatter over the surface of the ground, if somewhat poor, a coating of rich manure, and let it remain all winter. In the spring remove the coarse manure, and again rake the ground smooth and even, and sow on the seed. We are always disposed to advocate a liberal quantity of seed, for the simple reason that as the seed is but a very small item of the expense of making a lawn, and as it is always desirable to have a thick, close turf as soon as possible, it is advisable to sow thickly fancy Kentucky blue grass. Some prefer to add a little white clover. With thick sowing, we can accomplish in one season what with thin sowing may take two or three seasons, or even longer, to the bitter disappointment of the owner. We have had a very extensive experience in the seeding of lawns. Gradually we have increased the quantity of seed until now we use at the rate of about six bushels to the acre with most satisfactory results. Finish off by rolling with a moderately heavy lawn roller, and patiently await the results. If everything is favorable, a nice green lawn about the first of August will be the result. Run the mover over it frequently, and remove all obnoxious weeds. The first season the grass may be a little thin, but one season more will make it as thick and velvety as the best of turf. If the grass apears very thin in spots, sow on these a little more seed the following spring. Can be sown at any season of the year. Fancy Kentucky Blue Grass, 20c per lb.; fancy White Clover, 30c per lb. Mail, 10c per lb. extra. Larger quantities at lowest market price. (Subject to variation.)

\section{STRAWBERRY PLANTS-In Season.}

If sent by mail add 20 cents per 100 extra.

Edwards' Favorite, Sharpless, Jessie, Wilson, Manchester, Jucunda, Captain Jack Charles Downing.-25c per dozen; $\$ 1.00$ per $100 ; \$ 5.00$ per 1,000

Hood River or Clark's Seedling Strawberry.This new berry originated at Hood River, Ore- gon, where it is planted to the exclusion of all others for long distance shipments. It is larger than the Wilson, very firm. Color, a beautiful dark red, and quality unsurpassed. Price, $\$ 1.00$ per $100 ; \$ 5.00$ per 1,000 .

Also-Bismarck, Glen Mary and Wm. Belt.

\section{VEGETABLE PLANTS.}

Cabbage, Cauliflower, Celery, Tomato, Pepper, and Egg Pants on hand during the season at lowest market prices.

\section{ESCULENT PLANTS AND ROOTS.}

By Express only.

Asparagus Roots.-Per $100, \$ 1.00$.

Horse-Radish Roots.-Two to three inch lengths, $10 \mathrm{c}$ per $\mathrm{lb}$.
Chives Plants.-Per clump, 15c.

Rhubarb Roots.-Per dozen, $75 \mathrm{c}$.

Tarragon Plants (Estragon).-Per clump, 30c. 


\section{DECIDUOUS TREES, HEDGE, FRUIT AND FLOWERING SHRUBS.}

Ash, White.-(Fraxinus Americana).-This is one of the most valuable varieties for forest planting. It is adapted to a wide range of soil and climate. Its growth is extremely rapid, often attaining a growth of six feet in a single season. About 10,000 seeds to the pound. Per oz., 10c; 1/4 lb., 20c; 1 lb., 50c.

Apple.-(Pyrus Malus).-These seeds do not reproduce the same variety, but upon the stock thus raised from the.seed are grafted or budded the cuttings of such varieties as are desired. About 12,000 seeds to the pound. Per lb., $50 \mathrm{c}$.

Box Elder.-(Acer Negundo).-A mediumsized tree of extremely rapid growth, not usually attaining a height of over thirty feet. The wood is close and fine-grained. The sap contains a large amount of sugar. About 15,000 seeds to the pound. Per oz., 10c; $1 / 4 \mathrm{lb} ., 20 \mathrm{c}$; $1 \mathrm{lb} ., 50 \mathrm{c}$.

Catalpa, Hardy.-(Catalpa Speciosa).-Of all trees that have been suggested as adapted to the formation of timber plantations, the Catalpa Speciosa stands pre-eminent. The handsome appearance of the tree and the unrivaled beauty of its flowers all point to the Catalpa as the tree to plant. About 20,000 seeds to the pound. Per oz., 10c; 1/4 lb., 30c; $1 \mathrm{lb}, \$ 1.00$.

Bass Wood, or Linden, American.-(Tilia Americana).-A large tree of rapid growth; wood soft and white; lumber valuable. The foliage is luxuriant, and the flowers produce honey in great abundance. About 5,000 seeds to the pound. Per oz., $10 \mathrm{c} ; 1 / 4 \mathrm{lb} ., 30 \mathrm{c} ; 1 \mathrm{lb}$., $\$ 1.00$.

Elm, White.-(Ulmus Americana).-It is the largest of the native elms, often growing to the height of eighty feet. The wood is tough and valuable. It is well worthy of cultivation, both for its wood and ornament. About 50,000 seeds to the pound. Per oz., $10 \mathrm{c} ; 1 / 4$ lb., $30 \mathrm{c} ; 1 \mathrm{lb}$., $\$ 1.00$.

Locust, Yeilow or Black.-(Robina Pseudo Acacia).-This variety is noted for its rapid growth of hard and durable timber. It is hardy and succeeds well in Colorado. It is well worthy of a trial in any locality where it has not already been tested. The best for timber claims. About 25,000 seeds to the pound. Per oz., $10 \mathrm{c} ; 1 / 4$ lb., $15 \mathrm{c} ; 1$ lb., $50 \mathrm{c}$.
Locust, Honey.-(Gleditschia Triacanthos). - This is a large and handsome tree, the trunk and branches generally beset with long and formidable spines, on which account it has been employed as a hedge plant. Seeds ought to be scalded before planting. There are two varieties; one with thorns and the other thornless. About 2,000 seeds to the pound. Per oz., $10 \mathrm{c} ; 1 / 4 \mathrm{lb} ., 15 \mathrm{c} ; 1 \mathrm{lb} ., 50 \mathrm{c}$.

Osage Orange.-(Maclura Aurantiaca).-A native of Texas, but has been generally introduced over the country from its extensive employment as a hedge plant. The best way to prepare seed for planting is to soak it in a running creek until it commences sprouting, then plant like any other seed. Another way to sprout it is by putting it into a vessel and covering it with warm water until the sprouts come out. We prefer the first method. Proper time to sow is in April or May. About 10,000 seeds to the pound. Per oz., 10c; $1 / 4$ lb., 15c; 1 lb., 40c.

Pine, Scotch.-(Pinus Sylvestrus).-One of the most valuable of European varieties. It is tough and hardy, of very rapid growth, adapted to a great variety of soil and climate. Its extreme hardiness, together with its dense foliage, makes it of great value for shade. About 70,000 seeds to the pound. Per oz. 20c; $1 / 4$ lb., $60 \mathrm{c} ; 1 \mathrm{lb} ., \$ 2.00$.

Russian Mulberry.-(Morus Tartarica).-Said to be the most valuable variety for our climate. It is easily cultivated, hardy, a good grower, and if kept in dwarf form will make a fine hedge. The berries of the Russian Mulberry are good for dessert. The tree makes good fence-posts after five years' growth, and eventually makes splendid lumber for cabinet work. About 200,000 seeds to the pound. Per oz., $30 \mathrm{c} ; 1 / 4.1 \mathrm{lb} ., \$ 1.00 ; 1$ lb., $\$ 3.50$.

Walnut, Black.-(Juglans Nigra).-One of the most valuable varieties for timber planting. A very large tree of rapid growth. It delights in a rich soil, and luxuriates in our prairie loams or timber land clay. Its lumber has a very high market value, and is becoming very scarce. The nuts are a well-known article of commerce. One lb., 5c. 


\section{CLOVER AND GRASS SEEDS.}

As prices are variable we can not make prices in catalogue. Orders are filled at lowest market prices on receipt of order.

We pay particular attention to this department of our business. These seeds are selected with special reference to their quality. Purchasers may rely upon our best exertions to furnish grass and field seeds fresh, pure and free from noxious and foreign seeds. We handle nothing but the best seeds, and all re-cleaned by the best machinery, to make it choice.

\section{ALFALFA (Medicago Sativa).}

Alfalfa, or Lucerne, is a deep-rooting, perennial plant, sending up numerous small and clover-like shoots. Leaves pinnately foliate, leaflets obvate-oblong, toothed; the flowers, instead of being in a dense head as in clover, are in erect racemes; the corolla is a violet purple, and the many-seeded pod is spirally coiled. These blossoms are rich in honey food. It does

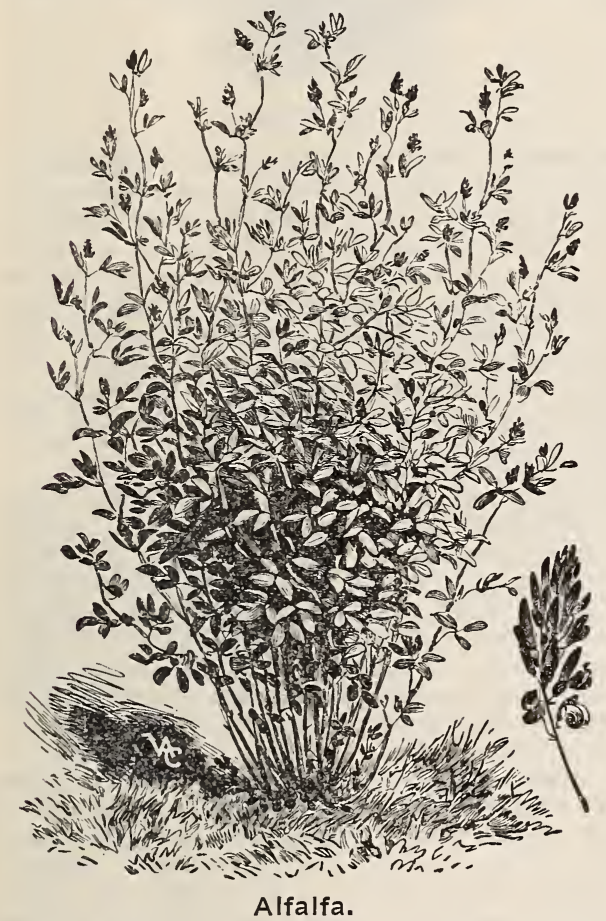

not thrive well in a compact clay soil or in any shallow soil having a clay bottom, but requires a sandy loam, the richer the better, such as abounds in all the valley lands of Colorado.

Alfalfa flourishes up to an altitude of 7,500 feet above the level of the sea, but at points higher it is likely to kill out before strong roots are secured. Spring rains, as a rule, answer until within a week of the first cutting, when a thorough irrigation is desirable, though often a first crop is cut without further moisture than the natural rainfall. Irrigate immediately after a crop is removed from the field. The first year, if sown early and a good stand is obtained one cutting; second year, two, though some have extra good fortune to get three cuttings; third year and thereafter, three and four crops, with a good aftergrowth remain- ing, making excellent winter pasture. Cut when in full bloom, not later, unless you want stalks instead of hay. In making hay, cut one day, lay it in the swath and cure all next day, raking up early on the morning of the third; if the sun should not shine clear, a longer time may be required. Never shake it out or turn it in the swath in this country, as it will cure perfectly without it, and the more it is turned and disturbed the more it will lose of its leaves and fine stems. Cock it up immediately after raking while yet damp with dew, if possible, and let it cure in the cock from one to three days before stacking. Its value as food for stock of all kinds is yearly becoming more evident. It is far superior to ordinary clover or meadow hay.

Medium Red Clover-(Trifolium Pratense).Is a perennial, but of very few years' duration; is nutritious and palatable for cattle, sheep and horses. $10 \mathrm{lbs}$. to the acre.

Large Red, or Pea-Vine Clover-(Trifolium Pratense).-The English Cow Grass; for plowing under. $10 \mathrm{lbs}$. to the acre.

Scarlet Clover-(Trifolium Incarnatum).-An annual, with crimson flowers. Sown late in the summer it furnishes an early green fodder the following season. $20 \mathrm{lbs}$. to the acre.

Alsike Clover-(Trifolium Hybridum).-Resembles in growth, duration, etc., the Red Clover; thrives well in cold, wet and stiff soils. 10 lbs. to the acre.

White Clover-(Trifolium Repens).-Valuable for lawns and pastures.

Sainfoin-(Onobrychis Sativa).-This is a very valuable perennial plant for the Southern states; it is quite hardy after it becomes well established. It has strong, deeply branching roots, and will succeed in very dry soils, sand, and even in gravel. Sow two to three bushels per acre. Bushel weighs about $24 \mathrm{lbs}$.

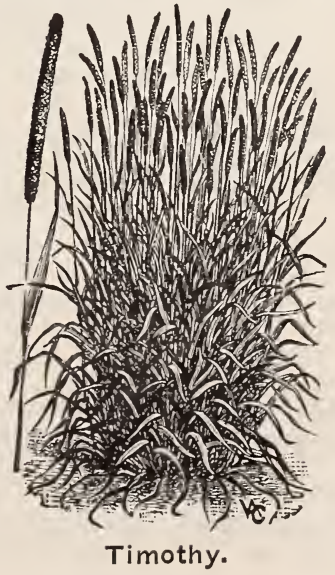


Timothy-(Phleum Pratense).-A grass so well known it needs no description, except that, for a hay crop on moist, peaty or clay soil, it will produce a larger crop than any other sort. It is not well suited for light, sandy soils. Half bushel to the acre. $45 \mathrm{lbs}$. to the bushel.

Red Top Grass-(Agrostis Vulgaris).-A valuable permanent grass as a mixture in either meadows, pastures or lawns, growing in almost any soil, moist or dry, and standing well our hot climate. Sow two to three bushels to the acre. $14 \mathrm{lbs}$. to the bushel.

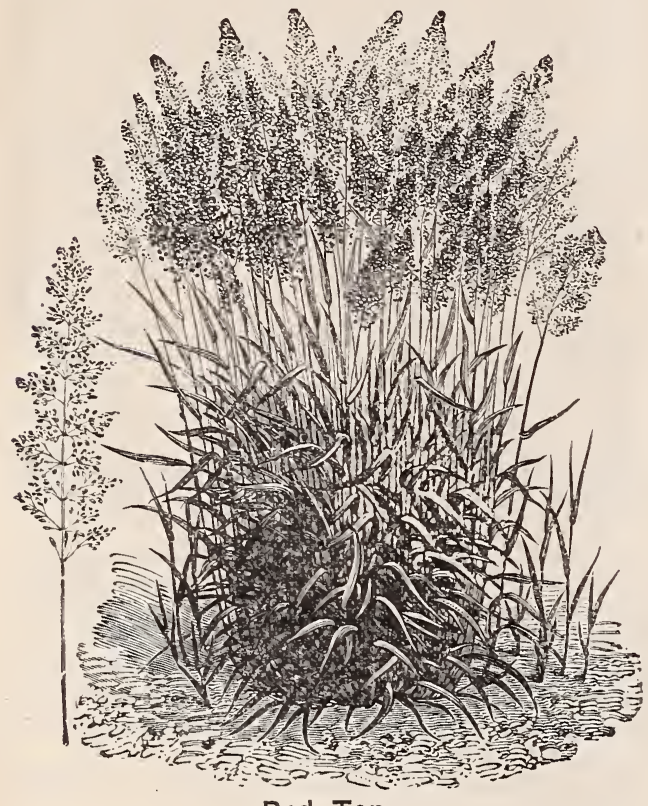

Red Top.

Fancy Heavy Red-Top Grass.-Absolutely clean and free from chaff. Sow about fifteen pounds to the acre.

Orchard Grass-(Dactylis Glomerata).-No farmer should be without a small. field of Orchard Grass, as in many respects it is superior to all other grasses. It stands the drought, grows well in the shade, does well in wet or poor ground, and is splendid to prevent wornout fields from washing. This grass furnishes excellent pasturage three weeks before any other, and after close grazing ten days' rest is sufficient to produce another growth. Cows fed on this will produce more and richer milk than on Blue Grass. Sow 25 to $30 \mathrm{lbs}$. to the acre.

Italian Rye Grass-(Lolium Italicum).-One of the most valuable grasses in Europe, being equally suited to all climates. In England it is considered the best-known grass to cut green for soiling, affording repeated large and nutritive crops. $30 \mathrm{lbs}$. to the acre.

English Rye Grass-(Lolium Perenne).-Is the staple grass of Great Britain, entering largely into the composition of many of the richest meadows and pastures. Its natural adaptation to almost all cultivated soils, and its early maturity, are the reasons it has hitherto been so extensively cultivated in preference to many other equally nutritious sorts. $30 \mathrm{lbs}$. to the acre.

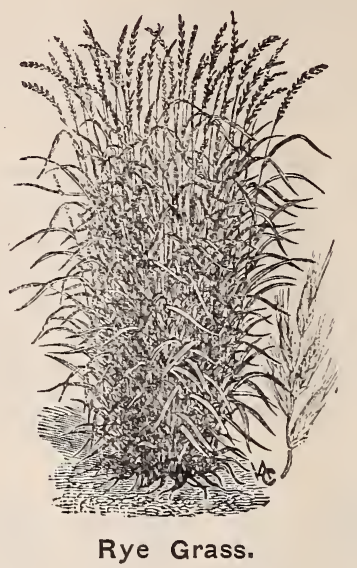

Kentucky Blue Grass-(Poa Pratensis).Also known as Green Grass, June Grass, etc., and thrives on a variety of soils, but does best in dry and somewhat shady locations. It requires several years to become well establishe-1 in the ground as a pasture grass. Very valuable for the Southern states, as it will stand the hottest summer. Two bushels to the acre. It is also a most valuable grass for the lawn, for which purpose from four to six bushels of clean seed to the acre should be sown. $14 \mathrm{lbs}$. to bushel. Fancy cleaned seed.

Meadow Fescue, or English Blue Grass-(Festuca Pratensis).-A highly valuable species for permanent grass land. It does not, however, attain to its full productive power till the second or third year, when it far exceeds most other sorts in quantity of its produce and nutritive matter. It is relished by live stock, both in hay and pasture, and is one of the most desirable permanent grasses for general culture. $20 \mathrm{lbs}$. to the acre.

Bromus Inermis, or Hungarian Brome Grass. -A wonderful drouth resister. A grass for the stock raiser. All cattle like it. Will drive out the Russian Thistle, also Black Mustard. (Extract from Bulletin of South Dakota Experimental Station.) While there are other grasses that give a better quality of hay than does the smooth brome grass, we have grown none at this station that has given as good returns one year with another. The grass has given paying crops every year for the past five seasons. The vield of seed is good, the hay is of good quality, though coarse when growth has been rank, and the grass promises well for use in permanent pastures. All kinds of stock eat it readily. Immediately after cutting, a fine growth of aftermath springs up which, with proper care, affords excellent fall and early winter grazing. In fine it possesses more of the qualities necessary for a good all-around plant for permanent pastures and meadows than any other grass grown on the station farm up to the present time.

Sow 15 to $25 \mathrm{lbs}$. per acre, in either fall or 
spring. Its nature is to stool out and thus does not show its best until the second season. It seldom produces seed the first year.

Aside from Alfalfa no grass has fulfilled the promises to our western farmers better than the Bromus Inermis. It meets drouth as well as wet and cold, and for Colorado we know of no grass to equal it. Many of our large ranchers are planting it extensively. Lb., 25c; $5 \mathrm{lbs}$. for $\$ 1.00 ; 25 \mathrm{lbs}$. at $18 \mathrm{c}$.

Sugar-Cane, Early Amber.-Its early maturity adapts it to almost every section. It has given entire satisfaction, whenever introduced, as a profitable crop for fodder as well as for sugar making. It usually grows eleven to twelve feet high, and stands well. If planted the first week in May the seed almost invariably ripens, thus giving a double crop each year, yielding twenty to thirty bushels of seed and 140 to 175 gallons of syrup to the acre.

German Millet.-No other plant that has yet been introduced here for grass or forage has been able to produce anything approaching the enormous yield of this plant when grown under favorable circumstances. It has produced from four to five tons of hay to the acre, and from seventy to eighty bushels of seed. Sow half a bushel to one bushel to the acre. $50 \mathrm{lbs}$. to the bushel.

Common Millet.-It is an annual grass, and its luxuriant leaves, being very juicy and tender, are much relished by all kinds of stock. It makes a very good hay. Sow from one-half to one bushel to the acre. $50 \mathrm{lbs}$. to the bushel.

Hungarian Millet.-This grass resembles the Millet very much, and it may be classed as a variety of that plant. It is of fine growth and makes an excellent hay. It has numerous succulent leaves, which furnish abundance of green fodder, eaten by all kinds of stock. Sow half a bushel to the acre. 48 lbs. per bushel.

Manitoba or Hog Millet.-The seed is very rich and thus especially valuable as a hog food. A very much prized peculiarity of this millet is that the seed ripens while the stem is yet green, thus if cut promptly can be threshed for the seed, while they hay after being threshed will make excellent fodder. Sow same as other millet. Lb., 10c., 10 lbs., 50c.

Broom Corn.-There are many farmers who might make this a very profitable crop. An acre will give about five hundred weight of broom and nearly forty bushels of seed, worth nearly as much as oats for feed. 46 lbs. per bushel.

Buckwheat, Common.-Buckwheat should be sown about the 20 th of June, broadcast, at the rate of from twenty-five to forty pounds per acre. It should be threshed as soon as dry on the ground or barn floor. If allowed to stand in mass it quickly gathers moisture. $52 \mathrm{lbs}$. per bushel.

Buckwheat, Silver Hull.-This improved variety is much better than the old sort. It is in bloom longer, matures sooner, and yields double the quantity per acre. The husk is thinner, the corners less prominent, and the grain of a beautiful light gray color. The flour is said to be better and more nutritious. $52 \mathrm{lbs}$. per bushel.

Buckwheat, Japanese.-This new variety has been raised here with good results, it is early and very productive. The kernels are twice the size of any other buckwheat, of a rich dark brown color and manufactures a superior flour. Owing to its branching character only one-half as much seed is required per acre; while the straw is much stiffer and stands up better. Lb., 10c; 10 lbs., 60c.

Mammoth Russian Sunflower.-Single heads measure twelve to twenty inches in diameter, and contain an immense quantity of seed, which is highly valued by all farmers and poultry breeders who have tried it, as an excellent and cheap food for fowls. They eat it greedily, fatten well on it, and obtain a bright, lustrous plumage and strong, healthy condition, better than almost any other food.

White Kaffir Corn.-It grows from four to five feet high, making a straight, upright growth. It has a stally stem, with enormous wide leaves. The stalks keep green and are brittle and juicy, not hardening like other varieties of sorghum, making excellent fodder, either green or dried, which is highly relished by cattle and horses. The seed heads form at the top of each stalk, and as soon as these show the grain well, the joints next below the top send up shoots which yield the second seed heads. For the grain sow in rows three feet apart. Lb. $10 \mathrm{c} ; 5$ lbs., $25 \mathrm{c}$.

Red 'Kaffir Corn.-This grows taller than the white; the stalks are slenderer, but more juicy and very leafy. The heads are long, slender, compact and grow erect; they measure from one to two feet. The seed is red, smaller than that of the white, and rather hard and brittle. It does well on poor land and yields well. It ripens a little earlier than the white variety, and yields much heavier. It is highly recommended by the Kansas Agricultural College at Manhattan. Lb., 10c; 5 lbs., 25c.

Jerusalem Corn.-It is pronounced the best and surest grain crop for dry countries and seasons, even better than Kaffir Corn and Milo Maize. It grows about three feet high, makes one large head on main stalk and several smaller heads on side shoots; have seen as high as eight heads on one stalk. The grains are pure white and nearly flat. Lb., 10c; 3 Ibs., $25 \mathrm{c}$.

Senora, Defiance, Siberian and other Spring Wheats; Red Cross, White Clawson and other Winter Wheats.

Six Rowed and Bald Barley.

Spring and Fall Rye.

Seed Oats.

Blue Vitriol at lowest market prices.

Write for prices on Grain, Grass, Clover and Field Seeds.

Prices subject to market changes. 
USEFUL TABLES OF WEIGHTS AND MEASURES.

1 tablespoonful of salt equals 1 ounce.

Flour, 1 lb. equals 1 quart.

Ieal, 1 lb. 2 oz. equal 1 quart.

Butter, $1 \mathrm{lb}$. equals 1 quart.

White sugar, 2 lbs. equal 1 quart.

Ten eggs equal one pound.

A common tumbler holds half a pint.

A teacup holds one gill.

Two gills make one-half pint.

Two pints make one quart.

Four quarts make 1 gallon.

Half a gallon in one-fourth of a peck.

2 gallons, 1 peck.

8 gallons, 1 bushel.

\section{USEFUL TABLES FOR GUIDANCE IN SOWING VARIOUS SEEDS.}

Weights per bushel and amounts of seed sown to the acre:

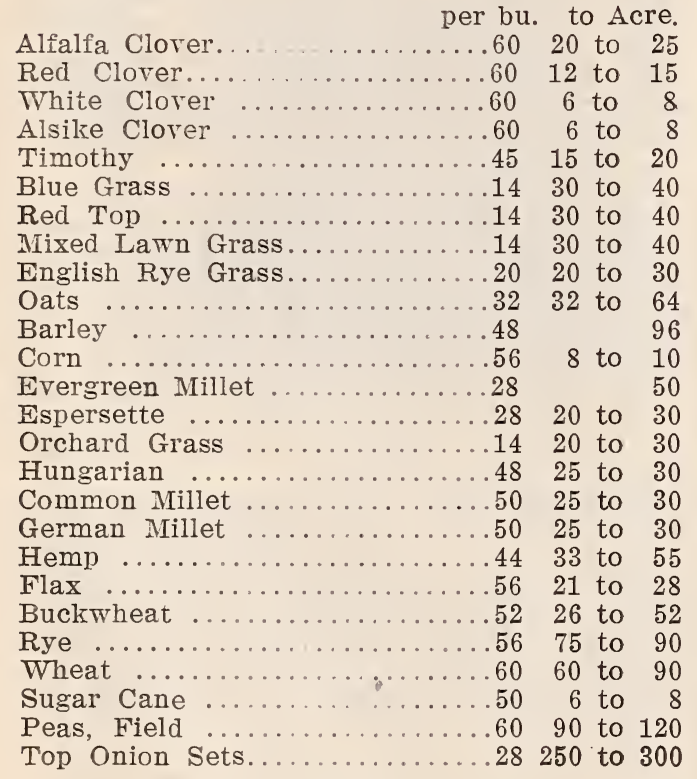

In Drills.

Dwarf Beans

Early Peas

75 to 90

75 to 95

Marrowfat Peas

Beets ..............

Mangel Wurzel

Carrots

Onions ...........

Onions for Sets.

Onion Sets

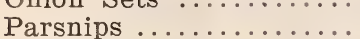

Radishes

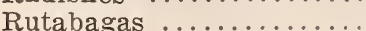

Spinach

Salsify
In Drills.

No. Lbs. to Acre.

Turnips $\ldots \ldots \ldots \ldots \ldots \ldots \ldots \ldots \ldots$ to $1 \mathrm{r} / 2$

Tomatoes to transplant............ 1 . $1 / 4$

In Hills.

Corn $\ldots \ldots \ldots \ldots \ldots \ldots \ldots \ldots \ldots \ldots \ldots$ to 10

Cucumbers ..................... 1 to $1 \mathrm{r} / 2$

Muskmelon .................. 2 to 3

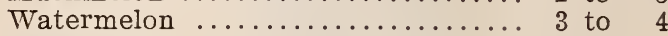

Pumpkins .................. 2 to 3

Squash .................... 2 to 3

Table to assist farmers and gardeners in making an accurate estimate of the amount of land in different fields under cultivation:

10 rods $x 16$ rods equal................ acre

8 rods $\times 20$ rods equal.................. acre

5 rods $x 32$ rods equal.............. acre

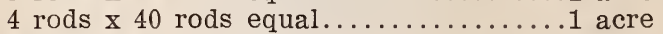

5 yards $\times 968$ yards equal............. acre

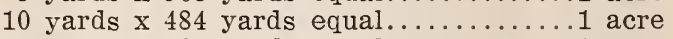

40 yards $\mathrm{x} 121$ yards equal............ acre

209 feet $\mathrm{x} 209$ feet equal................. acre

200 feet $\times 108.9$ feet equal.......... . $1 / 2$ acre

100 feet $x 145.2$ feet equal...........

100 feet $\times 108.9$ feet equal.......... $1 / 4$ acre

Table showing number of trees or plants that can be planted on an acre, at the distance apart given:

$1 x 1$ feet......43,560

$2 \times 1$ feet. . . ...21,780

$2 \times 2$ feet.......10,890

$3 \times 1$ feet. ......14,520

$3 \times 2$ feet. . . . . . 7,260

$3 \times 3$ feet....... 4,840

$4 \times 1$ feet. . . . . . 10,890

$4 \times 2$ feet....... 5,445

$4 \times 3$ feet...... 3,630

$4 \mathrm{x} 4$ feet....... 2,722

$5 \times 1$ feet...... 8,712

$5 \times 2$ feet. . . . . . 4,356

$5 \times 3$ feet. ..... 2,904

$5 \times 4$ feet...... 2, 178

$5 \times 5$ feet....... 1,742

$5 \mathrm{r} / 2 \times 5 \mathrm{r} / 2$ feet. . . 1,417

$6 \times 6$ feet...... 1,210

$61 / 2 \times 61 / 2$ feet....1,031 $7 \times 7$ feet...... 888 $8 \times 8$ feet........ 680 $9 \times 9$ feet........ 537 $10 \times 10$ feet...... 435 $11 \times 11$ feet....... 360 $12 \times 12$ feet....... 302 $13 \times 13$ feet........ 257 $14 \times 14$ feet....... 222

$15 \times 15$ feet....... 193

$16 \times 16$ feet. ...... 170

$17 \times 17$ feet....... 150

$18 \times 18$ feet....... 134

$19 \times 19$ feet....... 120

$20 \times 20$ feet....... 108

$25 \times 25$ feet....... 69

$30 \times 30$ feet....... 48

\section{Fence Post Table:}

6 feet apart...........880 posts to a mile 7 feet apart............ 755 posts to a mile

8 feet apart...........600 posts to a mile $16 \mathrm{~s} / 2$ feet apart...............

\section{WEIGHT OF MANURE TO APPLY TO DIF. FERENT CROPS PER ACRE.}

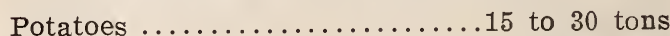
Mangel Wurzel ............20 to 30 tons

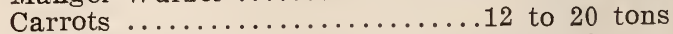

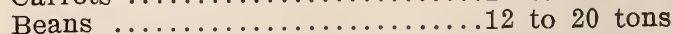

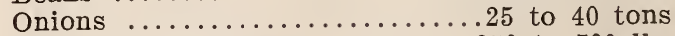
Peruvian Guano ............250 to $500 \mathrm{lbs}$ Nitrate of Soda and Potash... $250 \mathrm{lbs}$

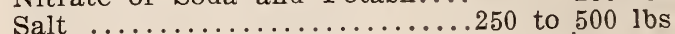

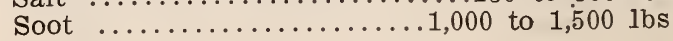




\section{HEADQUARTERS FOR BERRY BOXES, FRUIT PACKAGES, ETC.}

We always keep on hand a fine stock of boxes and crates and can fill orders promptly and at the lowest prices. The material used in the construction of our goods is of the very best and of well seasoned poplar, made from the heart of the log.

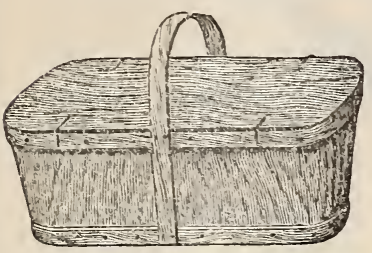

Climax Grape Baskets.

$5,7,8$ and 10 pounds. Handles and covers are shipped separate and baskets nested.

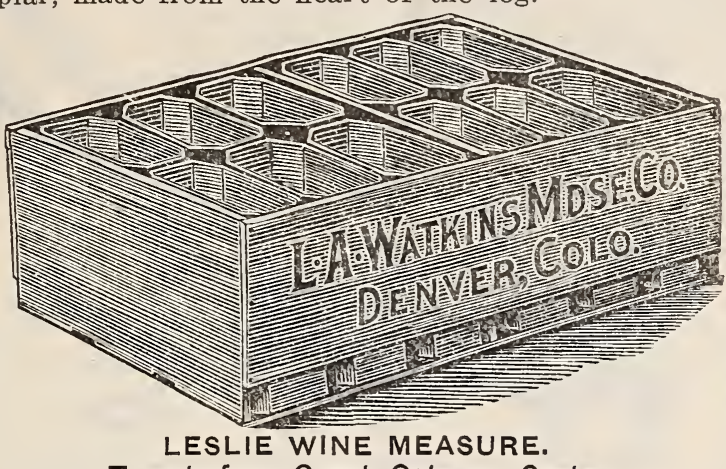

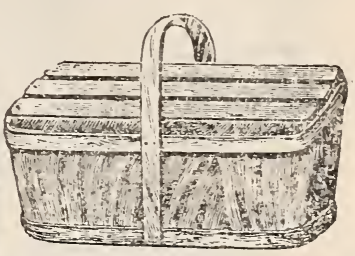

Climax Peach Baskets. Climax one-sixth and one-fifth bushel peach baskets, with raised slat cover.

Twenty-four Quart Octagon Crate.

This style of box is the standard octagon box for the western trade. We keep the quart boxes and crates for same as well as the pint octagon boxes, Swedish tacks, magnetic hammers and nails for crates.

Prices Given on Application.

\section{GARDEN TOOLS, ETC., ETC.}

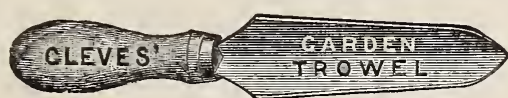

Garden Trowel-Cleves.'

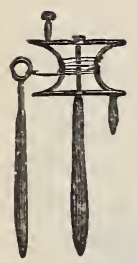

Garden Reel,

Price 65c.

Scollay Sprinklers,

$65 \mathrm{c}, 80 \mathrm{c}$ and $\$ 1.10$.

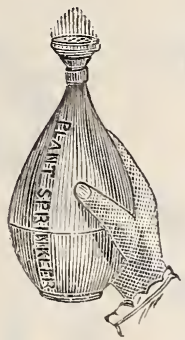

Steel Trowel-Is of one solid piece of steel, and will outwear several of the ordinary sorts. No. 3090, 6inch., $30 \mathrm{c}$ each, 3 for $75 \mathrm{c}$; No. 309, 6-inch, extra heavy, 40c each, 3 for $\$ 1.00$.

Common Riveted Trowel.-6-inch, 10c; 7inch, 15c; 8-inch, 20c.

Cleves' Angular Transplanting Trowel.Small, 20c; large, 35c each.

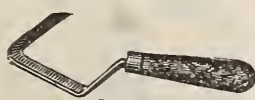

Hazeltine Weeder.-One of the best, solid steel, good size and durable; in very general use over the country. Each, 25c; postpaid, 30c; 4 for $90 \mathrm{c}$, not prepaid.

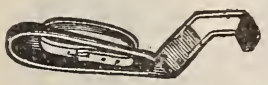

Lang's Hand Weeder.One of the best of this class, allowing use of hand while working. Each, 25c; postpaid, 30c; 4 for $90 \mathrm{c}$. Not prepaid.

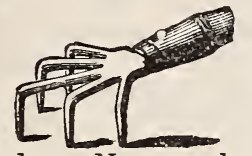

Excelsior Weeder.-A very useful tool for weeding seed beds, stirring ground, etc. This is one of the most useful tools in working the garden. No one should be without it. Each, 15c; postpaid, 20c; 3 for $35 \mathrm{c}$. Not prepaid.

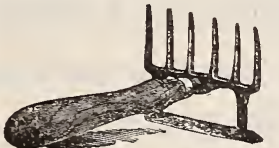

Combination Weeder.Combining, as it does, both the rake and hoe, it is the most serviceable, durable and the most perfect weedCombination Weeder. er on the market. Allows weeding close to the plants, and is offered at about the same price as other weeders. Each, 30c; postpaid, 35c.

Plant Dibber.-Has wooden handle with solid steel point. Used in making holes for setting out plants. 30c; by mail $40 \mathrm{c}$.

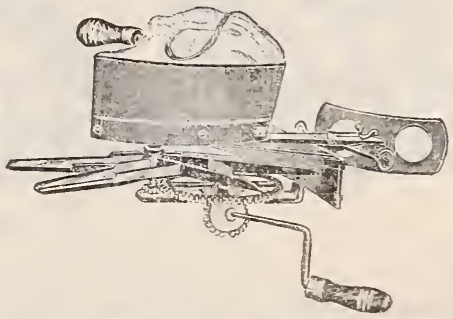

"The Daisy" Broadcast Seed Sower.

The simplest and the easiest running machine in the market. The grain bag is supported by a strap around the neck and held firmly against the body. The Daisy will sow any seed that is sown broadcast, such as alfalfa, clover, timothy, millet, wheat, oats, grass seeds, etc. Price, \$1.50. 


\section{Matthews' New Universal Model Garden Drill.}

PRICE, BOXED, \$8.00.

THE PERFECT DRILL; so acknowledged by all the leading seedsmen and market gardeners. The Agitator is a sure means of keeping the seed moving through constantly and uniformly, and is much preferable to any other method; and besides, there is nothing liable to get out of order or bind in the operation. When desired, the movement of the Agitator may be checked, and the drill then propelled forward or backward.

THE MOST SKILL. FUL HAND could not equal the mechanical precision with which it sows all the different varieties of Beet, Car. rot, Onion, Turnip, Parsnips, Sage, Spinach, Sorghum, Peas, Beans, Broom Corn, Fodder Corn, etc. Not only this, but the manner in which it opens the furrow; drops the seed accurately; covers it at any desired and equal depth; and lightly rolls the earth down over it, tends to hasten germination, and to present a young crop better able to withstand the weather.

THE FURROW OPENER is of the correct shape, and does not salve the soil. It may be accurately set to gauge the uniform deposit of the seed, at any required depth, thus avoiding the risk of planting at irregular depths, or so deep in places as to destroy the seed.

THE COVERING of Small Seeds should be shallow, while larger seeds should be plantec deeper. The depth may be gauged as desired. The Drags will throw just enough of the loose soil over the seed, and the concaved Roller then following, compacts and presses the whole down evenly, thus also preventing too free circulation of air, hastening germination and helping to bring moisture to the surface.

\section{Matthews' New Universal Constellation}

Seeder, Hoe, Cultivator, Plow, Rake and Marker.

PRICE, BOXED, \$10.50.

This illustration shows the complete instrument with all attachments furnished.

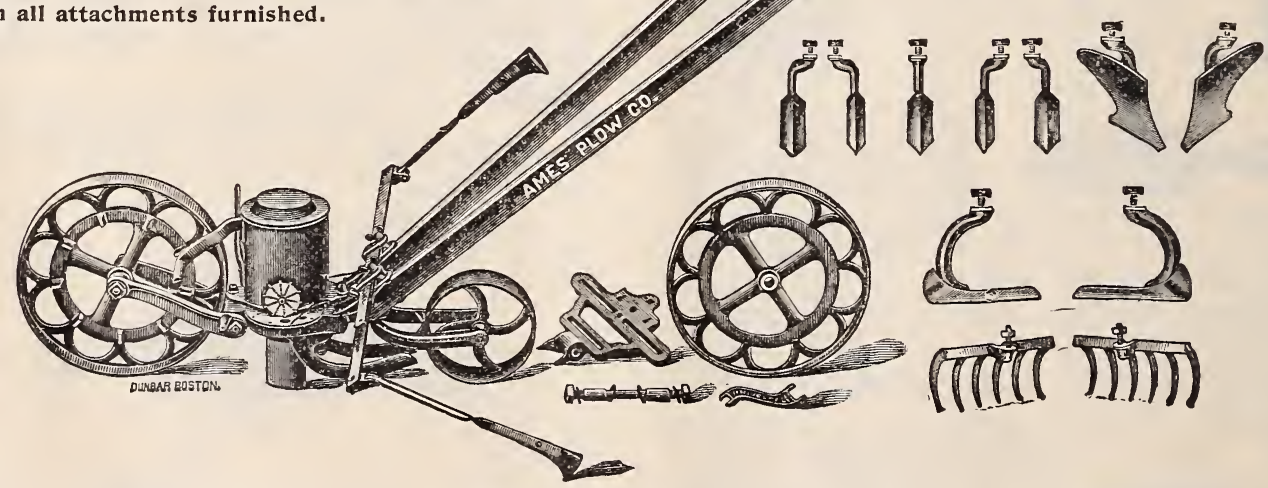

IN THIS CONSTELLATION is presented a brilliant assemblage of the New Universal Garden Drill, and the New Universal Wheel Hoe, Cultivator, Rake and Plow, for use either as a

ONE WHEEL
OR
TWO WHEEL $\left\{\begin{array}{ll}\text { Seeder, } & \begin{array}{l}\text { Cultivator, } \\ \text { Hoe, } \\ \text { Rake, }\end{array} \\ \text { Plow, } & \text { Marker. }\end{array}\right\} \begin{aligned} & \text { SIX } \\ & \text { IMPLEMENTS } \\ & \text { IN ONE. }\end{aligned}$

Each implement is entirely separate from the other and the only parts used in each, the Wheels and Handles, are changed from one frame to the other by only two bolts.

The Cultivating Attachments are shown detached. 


\title{
New Universal Double-Wheel Hoe, Cultivator, Plow and Rake.
}

\author{
Price, boxed, $\$ 6.50$.
}

THE SPECIAL DESIGN of this implement, is the working of both sides of the row, at one passing, by what is termed "straddle-row cultivation," but it may also be used as a between-row cultivator. All the good points of older efforts are retained, and in addition, new features are offered, which can not fail of appreciation.

THE ADJUSTABLE ARCH not only forms a means for gauging the depth of work to be performed; but, by an ingenious device enables the teeth to be pitched at any angle desired. This is especially advantageous for the Hoe Attachments, which are by far the most used of all.

THE ATTACHMENTS are:
1 Pair Hoes,
1 Pair Narrow Cultivators,
1 Pair Plows,
1 Pair Wide Cultivators,
1 Pair Rakes,
1 Pair Vine Guards.

THE OPERATION of a Hand Wheel Hoe, to obtain best results, is same as a scuffle hoe, with successive strokes of length to suit the nature of soil and crop. Study particularly into these conditions, as the closer

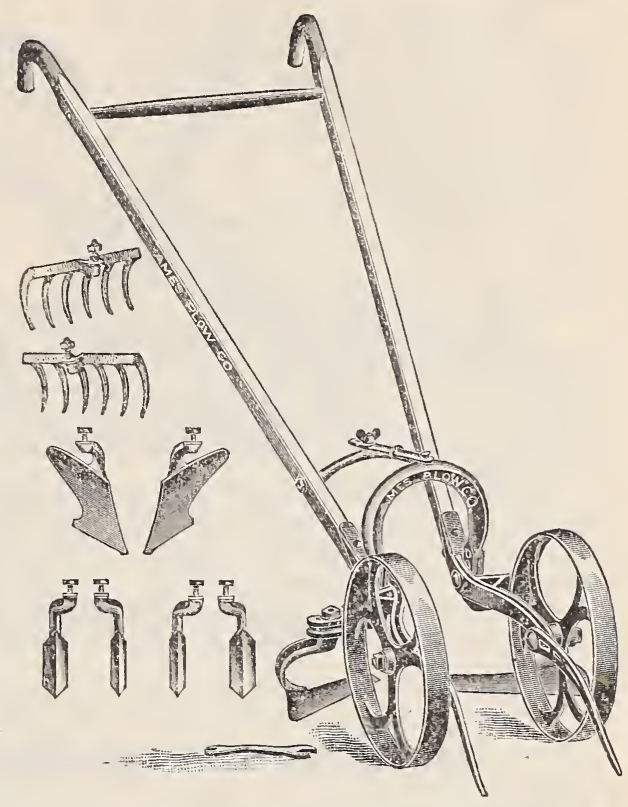
the crop is worked the better the results. It may be said that surface tillage forms a mulch of fine earth, to hold the moisture. Keep this mulch renewed and evaporation is arrested and the crop gets the full benefit of the moisture from the earth below. Keep the cultivators going, and the yield may be further increased if the non-conducting layer of fine earth is preserved through the season. DESTROY WEEDS and grass before they get firmly rooted, or better, by commencing the cultivation before they appear. After rains break the crust up as soon as the land is in suitable condition.

ALL THIS WORK may be done to advantage only by the use of Wheel Hoes. Where one Seeder is employed, several Wheel Hoes may be successfully used, at times of the day when this part of the work need not interfere with other duties, and wonderful results obtained, with excessive ease and at slight cost.

THE CONSTRUCTION of this implement is so symmetrical, that in passing astride rows of large plants the foliage once raised by the Vine Guards, meets no obstruction between the wheel arms and the arch, thus obviating the necessity of stopping, and the unnecessary damage to crop. It also admits of working larger plants than other implements of like size. There are nine adjustments of depth.

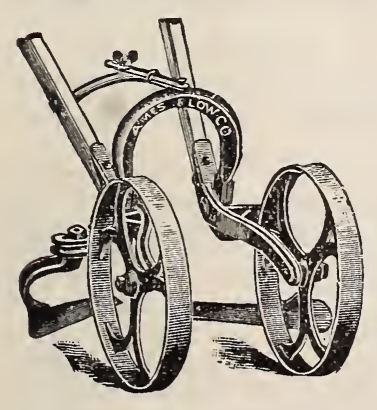

\section{NEW UNIVERSAL DOUBLE.WHEEL HOE.}

\author{
WITH HOE BLADES ONLY. \\ Price, Boxed, \$4.25. \\ If With Vine Guards, add 40 c.
}

THE EASE with which a great amount of work may be accomplished, by the use of WHEEL HOES, leads many to buy several of these tools. In such cases, it is not always necessary to have them all fitted out with complete sets of attachments. The HOE BLADES are the attachments most generally used. 


\section{NEW UNIVERSAL MODEL GEM SEED DRILL.}

THE GEM DRILL has been perfected to meet the demand for a low-priced seeder. We have not only accomplished this, but here offer a drill with all the essential qualities of the Matthews principle, even to embodying Seed Dial, Indicator and Reg. ulator from exactly same patterns as those used in our larger and more expensive drills.

THE MARKER is of a less expensive pattern, but such as is generally employed on other drills for which a higher price is asked. It may be set for the various distances and is thrown from side to side, being pivoted between the handles.

ADJUSTMENTS.-All that are necessary to a successful improved Seed Drill, are provided, including the MANUAL SEED "CUT-OFF" for checking flow of seed at ends of rows. We do not recommend this drill for use instead of the larger size, but we are sure that all in want of such a drill as we represent this to be, will find it to their advantage to buy the Gem.

\section{New Universal Single-Wheel Hoe, Cultivator, Plow and Rake.}
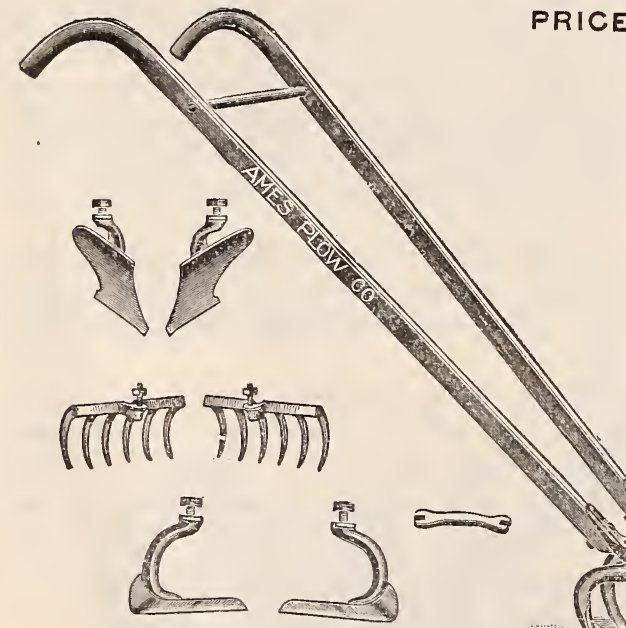

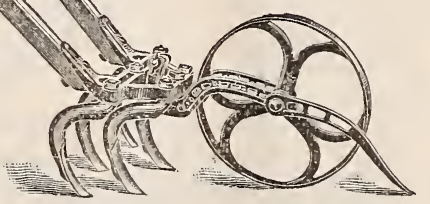

THIS FORM of Wheel Hoe is preferred by many, and, as with the Double Wheel Hoe just described, may be used either between or astride the rows. For straddle cultivation, the wheel may be set on one side, so as to bring the rows of young plants under center of frame. Later cultivation must be done between rows.

THE ATTACHMENTS are:

1 pair Narrow Cultivators, 1 pair Plows,

1 pair Wide Cultivators, 1 pair Rakes,

1 pair Hoes, 1 Center Cultivator, 1 Vine Guard.

THE ADJUSTMENTS, five in number, for graduating the depth of cultivation, are unique and readily accomplished.

NEW UNIVERSAL HAND.WHEEL PLOW.

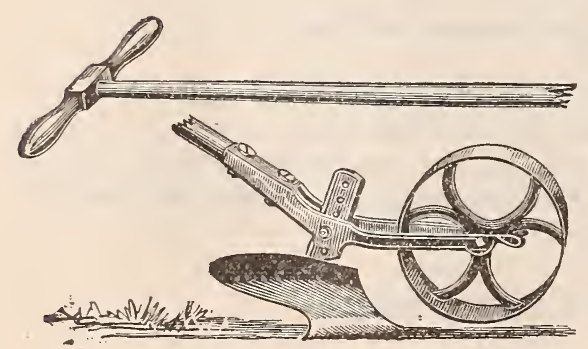

PRICE, BOXED, \$2.50.

THIS little labor saving implement is one that commends itself to all gardeners. It can be used to prepare the ground, to furrow out, to cover, and to cultivate. The mould-board is of steel, polished and tempered. The Hand Plow is also a very useful implement for the poultry raiser for loosening up the runs or yards. 


\section{ONE=HORSE CULTIVATOR.}

The several combinations which can be fitted to these cultivators make them quite popular, and they should not be classed with the cheap implements of this nature now on the market. The lever above shown is used for narrowing or widening the tread, which can be done while the horse is in motion. The depth is regulated with the gauge wheel.

\section{PRICE \$6.70}

We can furnish Horse Hoe Attachment with Sweeper, if desired. Price, $\$ 1.60$ Extra.

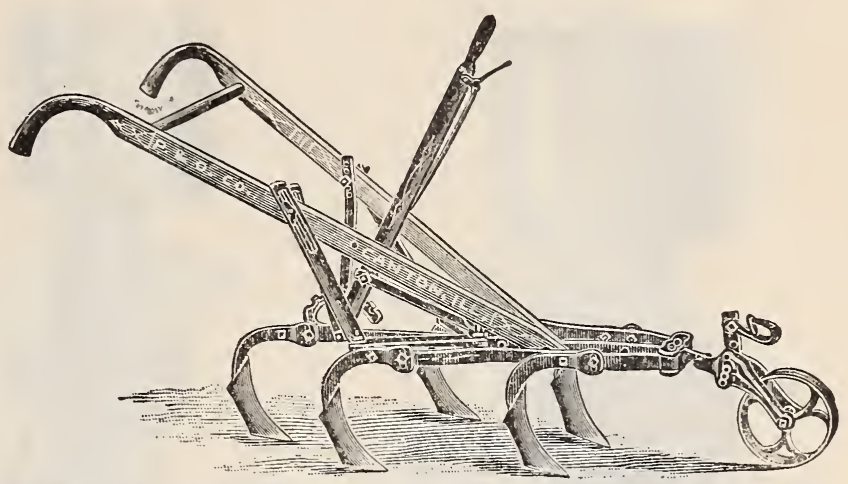

Steel Frame Five-Tooth Cultivator, with Lever Attachment and Gauge Wheel.

\section{The Clipper Grain and Seed Cleaners.}

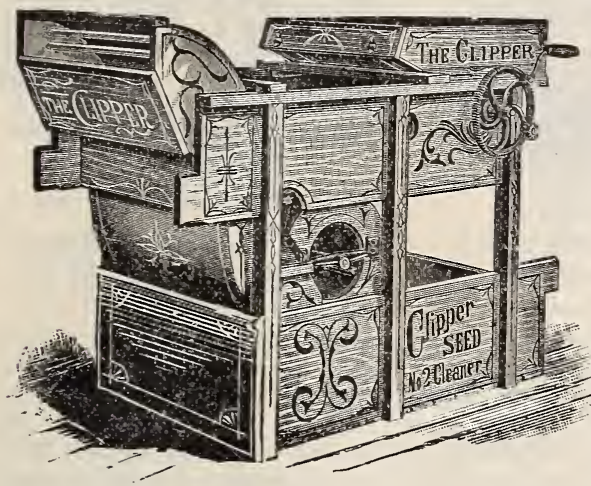

The Clipper-No. 1. Hand Power, PRICE \$25.00.

Capacity:

Market Wheat, 40 Bushels per Hour. Clover Seed, 12 Bushels per Hour.

ALL OUR MACHINES ARE COMPLETE FOR WORK REQUIRED.

NO EXTRA ATTACHMENTS NECESSARY. Size of Screens, $19 \times 30$ inches.

One wire and seven perforated zinc screens, equipped with spreading boards, furnished with each cleaner.

This Cleaner is adaptable for cleaning all classes of grain or seeds, such as Wheat, Corn, Oats, Barley, Rye, Beans, Peas, Buckwheat, Millet, Rice, Coffee, Spices, Clover, Alfalfa, Timothy, Mustard, Flax, Etc., Etc., and is suitable for farm or general use. Unlike other mills, the "Clipper" cleans all classes of seed and grain thoroughly in one operation, without any waste, and leaves no tailings to be rehan. dled. Effectual separation of plantain from clover seed is accomplished, removing all im- perfect and foreign seed therefrom, as well as cleaning the perfect seed.

Other manufacturers depend entirely upon screens for this work, and with unsatisfactory results. The "Clipper," however, screens all straw and foreign matter from the grain before it enters the air-shaft, and our "vertical blast" does the rest.

Our screens are so arranged as to be in plain view and of easy access to the operator while the machine is in operation.

The above facts should dictate the purchase of this cleaner to any one desirous of obtaining a first-class, inexpensive and durable mill, for general use.

\section{The Clipper-No. 2.}

\section{PRICE \$37.50.}

Capacity, 20 bu. per hour on Clover; floor space, 2 ft., 6 in. $x 4$ ft., 2 in.; height, 39 inches; sieves, $25 \times 33$ inches.

This machine is for Seed Cleaning only-a hand mill of large capacity for the use of dealers in field seeds.

Furnished with eight sieves, seven zinc and one wire. Suitable for Alfalfa, Flax, Clover, Timothy, Millet, and all small field seeds.

More of the "No. 2 Clippers" are used by seed merchants than all the hand mills combined.

This is a hand-power machine of large capacity, especially constructed for cleaning seed. The No. 2 Clipper is especially popular with dealers in all classes of small seed, and, like our No. 1 machine, will separate plantain from clover seed without waste.

Our "End Shake" and "Vertical Blast" are features of this and of all other Clipper mills.

Note-Grain Screens, suitable for market cleaning, will be furnished when desired. Price, per set, $\$ 5.00$ extra. 


\section{DE LAVAL SEPARATORS.}

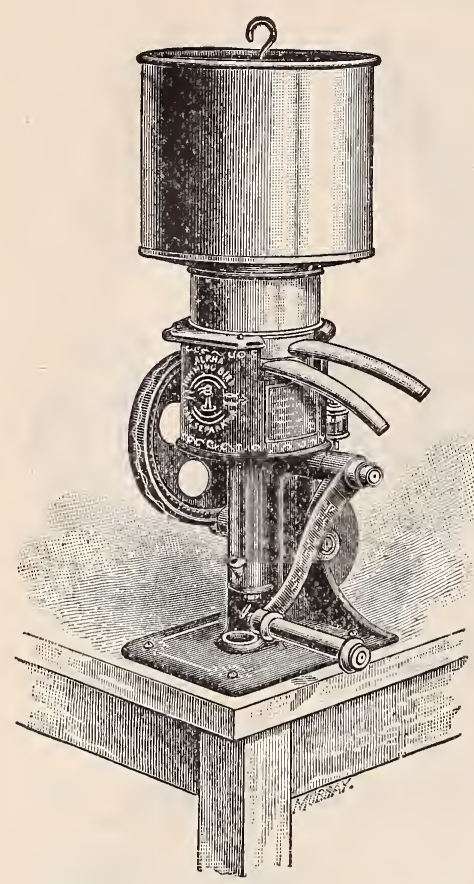

CRANK "HUMMING-BIRD."

Actual Capacity, 250 Lbs. per Hour. Price, $\$ 65.00$.

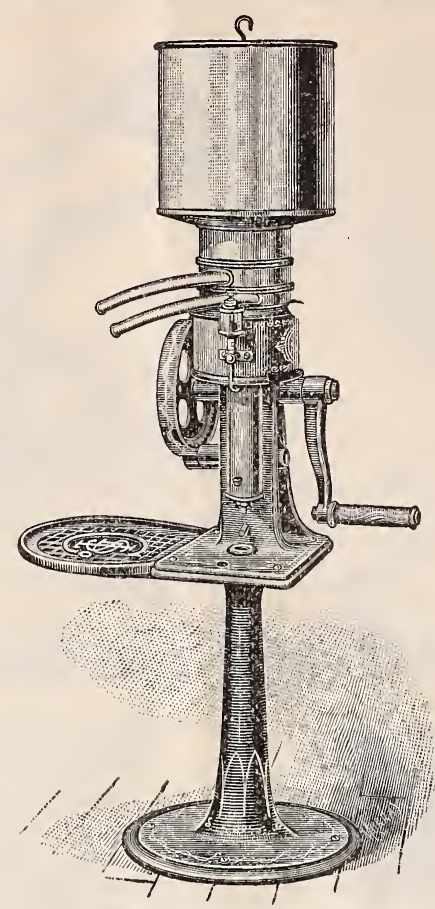

NEW STYLE "DAISY." Actual Capacity, 350 Lbs. per Hour. Price, $\$ 85.00$.

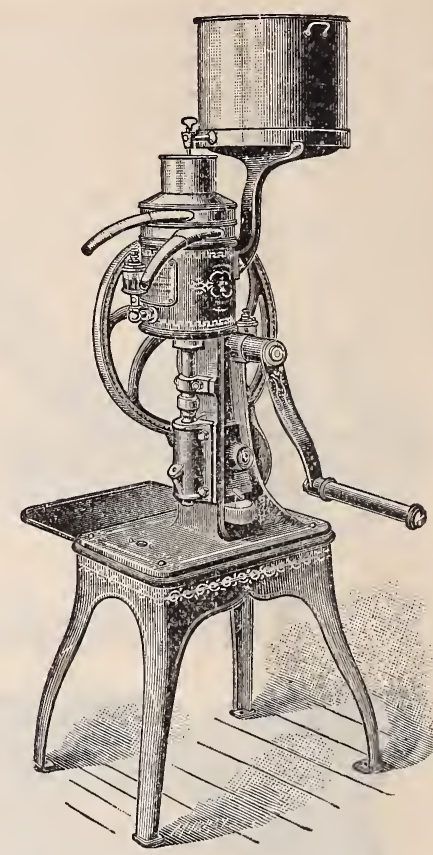

IRON-STOOL "BABY" No. 1.

Actual Capacity, 450 Lbs. per Hour. Price, $\$ 100.00$.

\section{CRANK "HUMMING-BIRD."}

The Crank "Humming-Bird," or New Style "Baby" No. 0 , is a later and somewhat improved pattern of the "Humming-Bird" size machine, being of gear construction, and built for crank operation, upon practically the same lines as the larger "Baby" machines. The 20th Century Crank "Humming-Bird" is made stronger in several ways. It possesses every advantage and improvement of the larger machines, and is meeting with a largely increasing sale, both to small dairy farmers having less than six or eight cows, and to owners of one or two/cows for private use, and gradually into city and village homes where milk is bought for household uses. There is also a constantly increasing use of this machine by the small hotels and restaurants, that cream of the best quality may be readily made as wanted, and the surplus of milk turned into superior butter. The Crank "Humming-Bird" is most extremely easy of operation, and the operator sitting in running it, almost without effort. Its increased capacity is now $250 \mathrm{lbs}$., and price, $\$ 65.00$.

\section{NEW STYLE "DAISY.”}

The "Daisy" is a new style and size of machine, of somewhat similar pattern to the "Humming-Bird," though heavier in construction and provided with an iron stool or supporting stand with cream receptacle shelf, etc. It is designed to meet the requirements of users wanting a size of machine between the more lightly built "Humming-Bird" and the larger capacity "Baby" No. 1 and No. 2 machines. It is very easy of operation and of the very latest and most approved design in every feature. It is intended for dairies of from 3 to 10 or even more cows, though capacity is an economy that must not be lost sight of in the selection of a cream separator and a consideration which is bringing about the use of large machines in even the smallest dairies. The increased capacity of the "Daisy" is now $350 \mathrm{lbs}$., and the price, $\$ 85.00$.

\section{IRON-STOOL "BABY" NO. 1.}

The Improved New Style "Baby" No. 1 is a recently created size of "Alpha" disc-bowl type of machine, designed especially to meet the needs of the user thinking himself unable to afford the cost of the larger "Baby" No. 2 machine, and preferring to give more time to the separation rather than to go beyond absolute necessity in first cost. It is intended for dairies of five to ten or fifteen cows, though the use of the larger capacity No. 2 machine is recommended as more practicable and economical in the long run in dairies of eight or more cows. The improved machine is of the latest springbearing pattern, and has a handsome iron supporting stand or stool furnished with it as a part of the machine, and is provided with gear shield in protection of the driving-wheel and pinion. Its increased capactiy is now $450 \mathrm{lbs}$., and price $\$ 100.00$. 


\section{DE LAVAL SEPARATORS-Continued.}

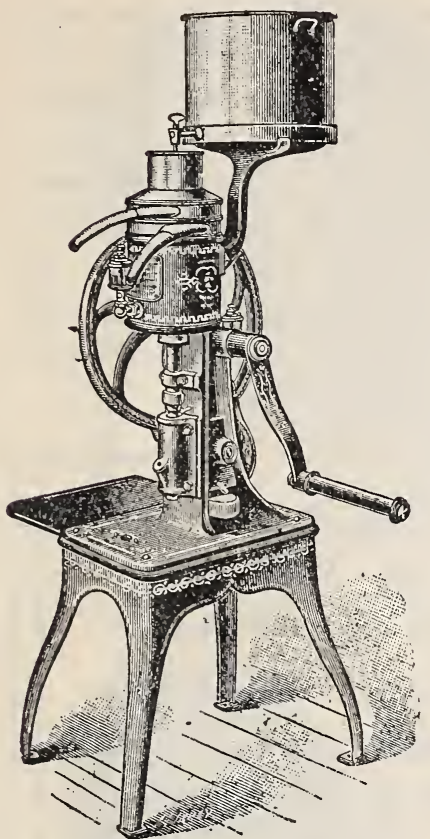

IRON-STOOL "BABY" No. 2.

Actual Capacity, 600 Lbs. per Hour. Price, $\$ 125.00$.

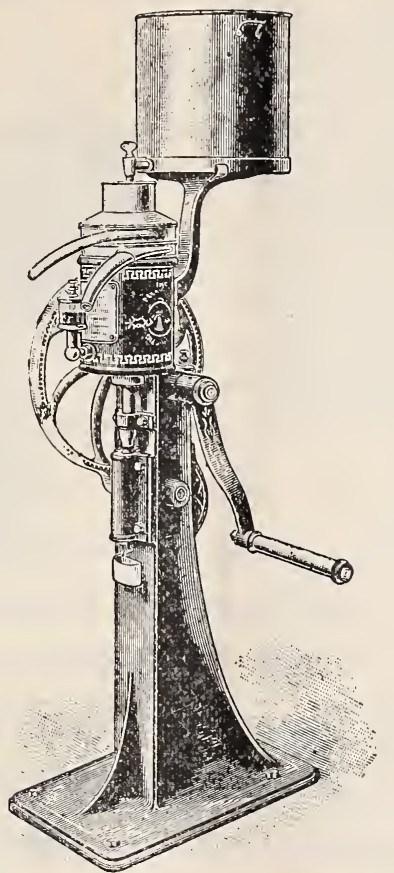

HIGH-FRAME "BABY" No. 2.

Actual Capacity, 600 Lbs. per Hour. Price, $\$ 125.00$.

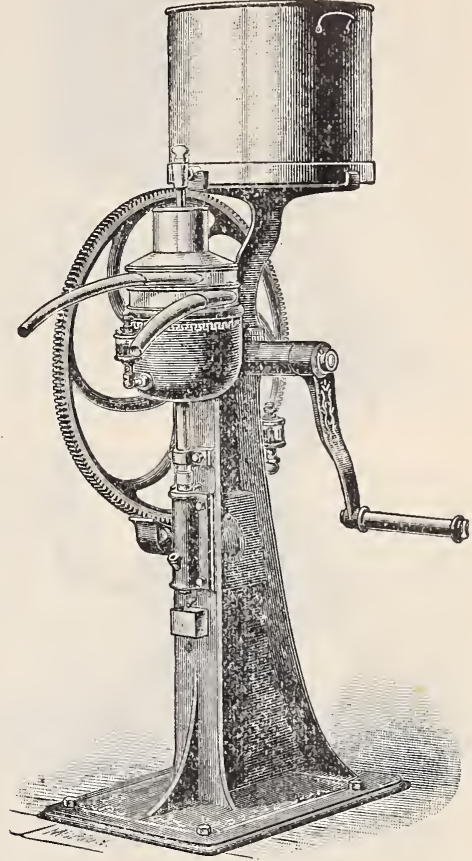

HIGH-FRAME "BABY" No. 3.

Actual Capacity, 1,000 Lbs. per Hour. Price, $\$ 200.00$.

\section{IRON-STOOL "BABY" NO. 2.}

The Iron-Stool "Baby" No. 2 machine is the latest improved type of the widely known lowframe style of "Baby" No. 2 machine. It is now made with a handsome iron stool or supporting stand, which is furnished as a part of the machine. It is also of the latest springbearing pattern and is supplied with gear shield in protection of driving wheel and pinion. The "Baby" No. 2 is the best known and heretofore most widely used dairy separator, and is the size of machine which has been mainly instrumental in revolutionizing farm dairying. As now made, it possesses many improvements over any previous form. It is intended for dairies of from five to twenty or thirty cows, and is often used in even larger ones. Its increased capacity is now 600 lbs., and price $\$ 125.00$.

\section{HIGH-FRAME "BABY” No. 2.}

The High-Frame "Baby" No. 2 is a comparatively new style of this size of machine, made in high continuous frame pattern similar in design to the well-known "Baby" No. 3. In other respects it is identical with the improved iron- stool style of machine. The intending purchaser of No. 2 size of machine may thus choose between the two styles, as shown in cuts. The general preference is for the iron-stool style, by reason of its greater convenience under varying setting conditions, while others consider the solid continuous frame more stable. The capacity and price of the high-frame machine are the same as those of the iron-stool one-600 lbs., and price $\$ 125.00$.

\section{HIGH.FRAME "BABY" No. 3.}

The "Baby" No. 3 is essentially the same as the "Baby" No. 2, other than that it is designed on a larger scale throughout. It is of the continuous solid frame pattern. Users of separators are beginning to appreciate the many greater advantages of creaming their milk quickly, as well as the economy of saving time in separation, as in everything else. The No. 3 is designed for dairies of twenty to seventy-five or more cows, but is now being largely used in dairies of even 10 to 15 cows, and frequently still fewer, by reason of its doing the same work in about half the time necessary with the No. 2. Its increased capacity is now 1,000 lbs., and price, $\$ 200.00$. 


\section{DE LAVAL SEPARATORS-Continued.}

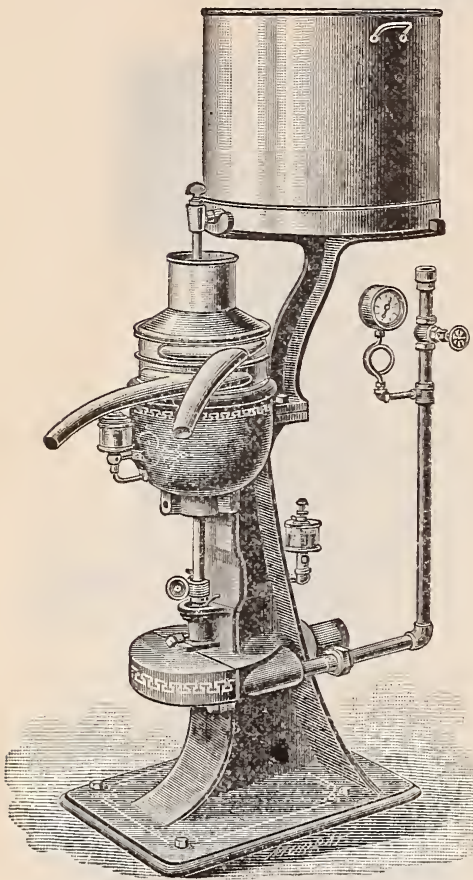

"DAIRY" STEAM-TURBINE.

Actual Capacity, 1,000 Lbs. per Hour. Price, $\$ 225.00$.

\section{"DAIRY" STEAM-TURBINE.}

The larger "Baby," or No. 3 machine, is also constructed in the form of the Dairy Turbine, for direct steam pressure connection. It is of exceptional excellence in its mechanical construction, and utilizes the latest improved principles of the DeLaval Steam-Turbine Factory styles of machines, including the steamtooth wheel motor mechanism. The turbine or steam pressure power, however, is alone applicable to this type of machine, and such means of operation is only advisable for farm and dairy requirements where power is desired to be used with the separator, but not for churning and other kindred work.

$\left|\begin{array}{l}\text { WE ALSO HANDLE ALL THE FACTORY SIZES } \\ \text { OF DE LAVAL SEPARATORS, VATS OF ALL } \\ \text { SIZES, COMBINED CHURNS AND WORKERS OF } \\ \text { ALL SIZES, PASTEURIZING OUTFITS; IN FACT, } \\ \text { WE HANDLE EVERYTHING PERTAINING TO } \\ \text { THE DAIRY AND CREAMERY SUPPLY LINE.......... }\end{array}\right|$

\section{Combined Churns and Butter Workers.}

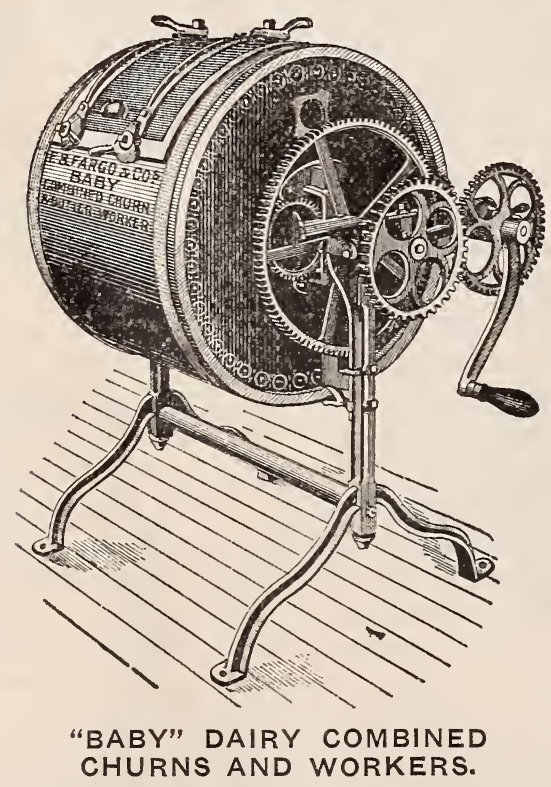

A Churn and Butter-Worker All in One.

This new Churn is the result of much study, and is offered to the dairymen and milk dealers of the country as an improvement on all previous efforts in this direction, with the belief that it is as nearly a perfect machine for buttermaking in the dairy as human ingenuity can reach.

The "Baby" is a geared machine, run by hand, and so constructed that two rollers and two simple lifting boards serve to do the churning and working of the butter, with no change of gearing except to remove the hand crank from the churning shaft, and slipping it onto the working shaft, the turning of which puts the rollers in motion, lifts the butter from the bottom of the churn, places it upon the rollers, and stops the churn until the butter passes downward through the rollers, then starts the churn again, and lifts the butter as before to the top of the rollers, continuing the process as long as the crank is turned.

The chief objection that has been raised against combined churns and workers for small dairies and for farm use, is their cost, and in producing the "Baby" we have sought to overcome this objection by bringing out a churn so low in price as to be within the reach of all.

The "Baby" is made with iron supports and frame, neat, light and strong.

\section{Sizes and Prices.}

No. 1 , capacity 5 to 30 pounds.........\$40.00 No. 2 , capacity 5 to 40 pounds.......... 45.00 


\section{Combined Churns and Butter Workers-Continued.}

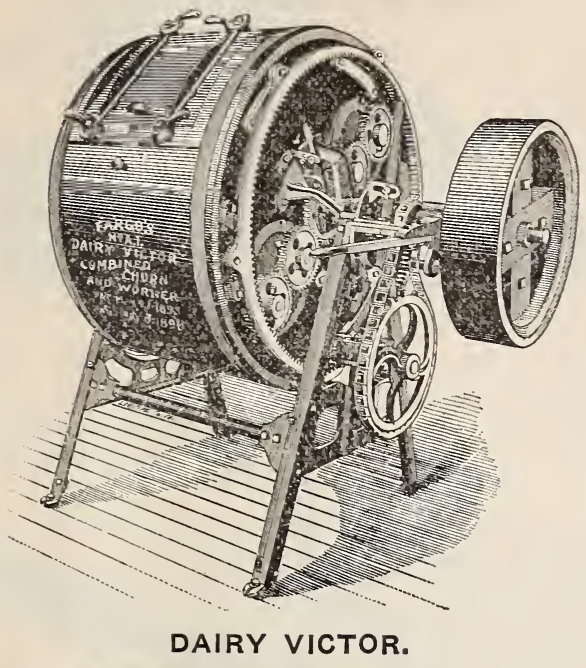

For years the effort has been made to create a dairy churn that would bring the small dairy to a level with the factory in the production of first-class butter in a rapid and uniform manner. Taking the factory "Victor" as a guide, we have at last produced a strictly Farmers' Combined Churn and Butter Worker, the "Dairy Victor," at a price that is within the reach of all, as complete in its operations as the now famous "Victor," and can be run by dog, goat, sheep or pony power. These three strictly farmers' churns are all furnished with pulley, and the Al machine can be run by hand; a crank is furnished when desired.

These churns have an 18-inch clutch pulley, with 4-inch face speed at 34 .

Specifications and Prices.

\begin{tabular}{|c|c|c|c|c|c|c|c|}
\hline \multirow[t]{2}{*}{ No } & \multicolumn{2}{|c|}{ Diameter } & \multicolumn{2}{|c|}{$\begin{array}{l}\text { Length } \\
\text { over all }\end{array}$} & \multirow{2}{*}{$\begin{array}{c}\text { Capacity } \\
\text { Lbs. }\end{array}$} & \multirow[t]{2}{*}{$\begin{array}{l}\text { Shipping } \\
\text { Weight }\end{array}$} & \multirow[t]{2}{*}{ Price } \\
\hline & Ft. & In. & Ft. & & & & \\
\hline & 2 & 10 & 3 & 8 & 10 to 60 & 250 & $\$ 60.100$ \\
\hline & 2 & 10 & 4 & 4 & 10 to 80 & 300 & 80.00 \\
\hline & 2 & 10 & 5 & & 10 to 100 & 350 & 100.00 \\
\hline
\end{tabular}

\section{CHURNS.}

No. 0. 5-gal. Churn, churns 1 to 2 gals. cream........\$3.60

No. 1. 9-gal. Churn, churns 1 to 4 gals. cream......... 3.80

No. 2. 15-gal. Churn, churns 2 to 7 gals. cream......... 4.00

No. 3. 20-gal. Churn, churns 3 to 9 gals. cream........ 4.50

No. 4. 25-gal. Churn, churns 4 to 12 gals. cream......... 5.40

No. 5. 35-gal. Churn, churns 5 to 16 gals. cream........ 7.20

In churning a larger amount of cream in the different sizes, Acme Barrel. more time will be consumed.

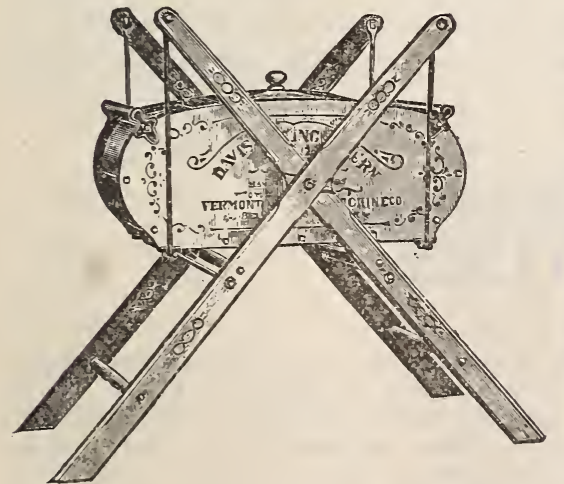

Davis Swing, Complete

\section{Size will Churn}

No. 14 gals., or less

No. 25 gals., or less

No. 38 gals., or less

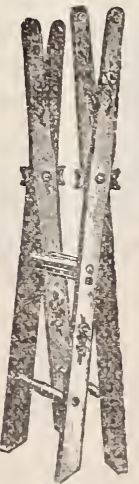

Frame.

Capacity weight Price 8 gals. 55 Lbs. $\$ 8.40$ 10 gals. $\quad 59 \quad 9.60$ 16 gals. $73 \quad 12.00$

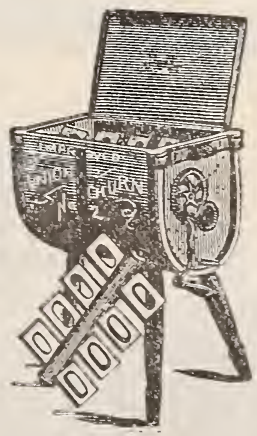

Improved Union.

No. 1 , churns 5 gals. cream...........\$4.50

No. 2, churns 7 gals. cream.......... 5.00

No. 3, churns 10 gals. cream.......... 6.25

No. 4, churns 15 gals. cream......... 8.50 


\section{Combined Churns and Butter Workers-Continued.}

\section{Churn Extras.}

Tight and loose pulleys, per set.......\$3.00

Cover cork, per foot................. 10

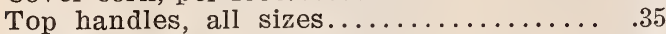

Cranks, 0 to $3 \ldots \ldots \ldots \ldots \ldots \ldots \ldots \ldots \ldots \ldots . .35$

Cranks, 4 and larger.................45

\section{Covers.}

$0 \ldots \ldots \ldots \ldots 1.00$

$1 \ldots \ldots \ldots \ldots \ldots 1.00$

$2 \ldots \ldots \ldots \ldots \ldots 1.50$

3 ........... 1.75

$4 \ldots \ldots \ldots \ldots 2.00$

$5 \quad \ldots \ldots \ldots \ldots \cdots+2.25$

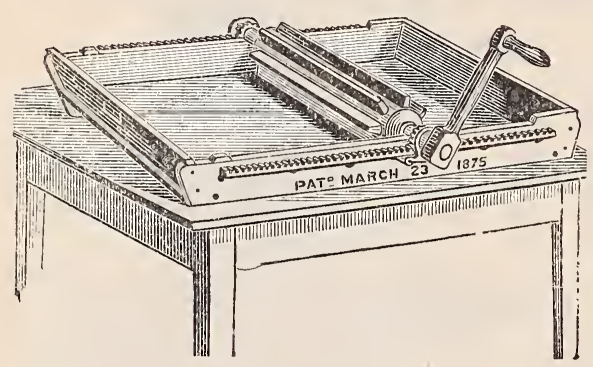

Short Trunions and Crank Trunions.

$0 \ldots \ldots \ldots \ldots \ldots+25$

$1 \ldots \ldots \ldots \ldots \ldots .25$

2............ .25

$3 \ldots \ldots \ldots \ldots \ldots \ldots+.35$

$4 \ldots \ldots \ldots \ldots \ldots .35$

5 . $\ldots \ldots \ldots \ldots . .35$

\section{Reid Butter Worker Extras.}

$\begin{array}{lllll}\text { No. I } & \text { No. } 2 & \text { No. } 3 & \text { No. } 4\end{array}$

Cogs $\ldots \ldots \ldots \ldots \ldots \ldots \$ 0.15 \quad \$ 0.15 \quad \$ 0.15 \quad \$ 0.15$

$\begin{array}{llllll}\text { Clamps } \ldots \ldots \ldots \ldots \ldots & .40 & .40 & .40 & .40\end{array}$

Racks, one side..... $1.25 \quad 1.00 \quad 1.00 \quad .90$

Washers ............ $.05 \quad .05 \quad .05 \quad .05$

End Plates........... $.05 \quad .05 \quad .05 \quad .05$

Rollers, wood...... $1.75 \quad 1.60 \quad 1.50 \quad 1.50$

Rollers, complete.... $3.90 \quad 2.50 \quad 2.25 \quad 2.25$

Cranks, iron arm.... $.60 \quad .60 \quad .50 \quad .50$

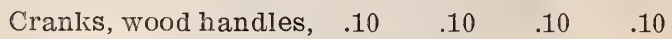

\section{Reid's Dairy Worker.}

No. 4. $14 \times 23$ in., $2 \frac{1}{2}$ in. deep inside, cap'y 10 tbs., weight $20 \mathrm{tb}$....................... $\$ 5.00$

No. 3. $17 \times 27$ in., $2 \frac{1}{2} 2$ in. deep inside, cap'y 20 Ibs., weight 25 tos.......................... 6.00

No. 2. $20 \times 36$ in., $2 \frac{1}{2}$ in. deep inside, cap'y 30 ibs.,

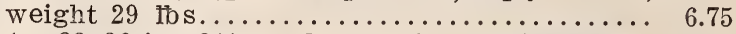

No. $1.23 \times 36$ in., $2 \frac{1}{2}$ in. deep inside, cap'y 50 ibs., weight 45 1bs.......................... 8.50

No. 0. $23 x 37$ in., 3 in. deep inside, cap'y 75 tbs.,

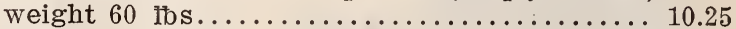

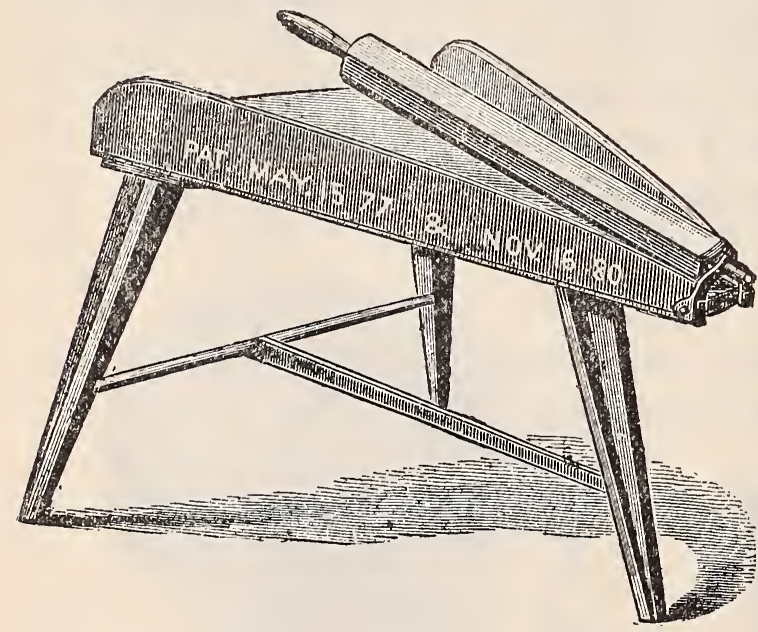

Lever Worker.

No. 0.20 inches wide, will work 15 pounds .................... \$ 5.00

No. 1. 30 inches wide, will work 25

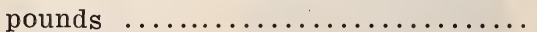

No. 2. 40 inches wide, will work 35 pounds ..................... 7.50

No. 3. Factory size, will work 50 pounds .................... 12.00

\section{Capacities.}

Three pounds can be worked in any of the above machines, as well as a larger quantity. In buying a machine you should choose a size that will work the largest quantity that you will be likely to want to work at a time.

\section{BUTTER PRINTERS.}

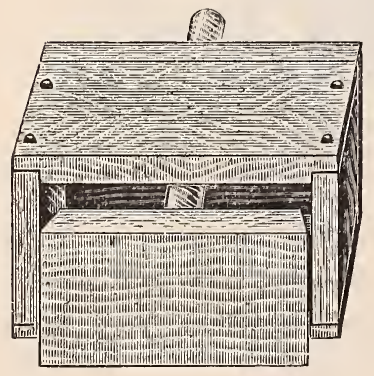

Have Your O'wn Brand.

In these days of imitation and adulteration we would advise every one to have their name, initials or brand cut in the print block. This would prevent imitation. To a person making uniformly good butter, this is of great value, as the special brand becomes their trade mark, and their butter commands a better price. The charge for carving blocks to order is from $\$ 1.00$ to $\$ 1.75$, according to the design.

\section{Favorite.}

This is a neat, substantial mould and is made of close-grained, hard wood, and on account of the low price, is one of the most popular moulds we sell. It makes the regular size brick-shaped prints, but is not adjustable. Price............................. $\$ 0.30$ 


\section{BUTTER PRINTERS-Continued.}

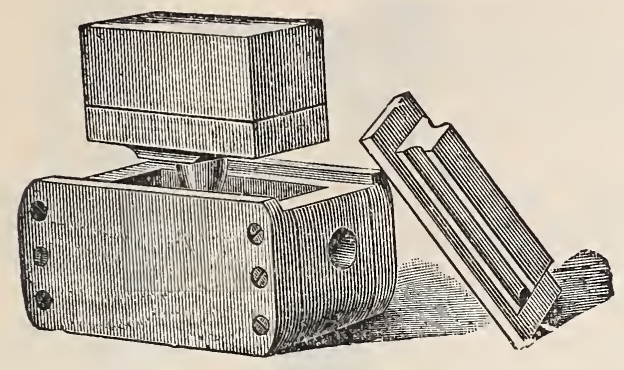

Reid's Family.

Not Self-Gauging.

With plain block.................\$1.25

With Sheaf of Wheat............... 1.50

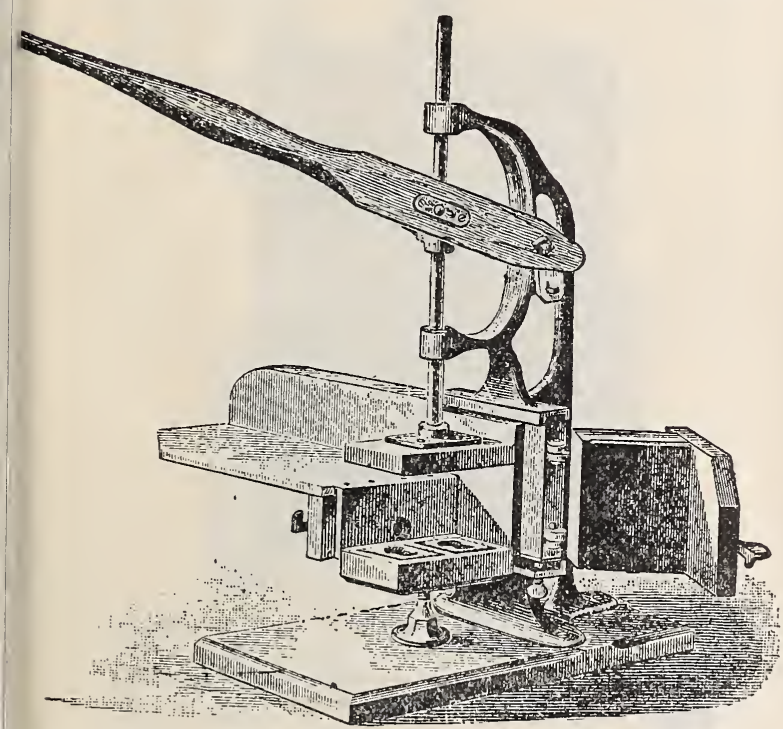

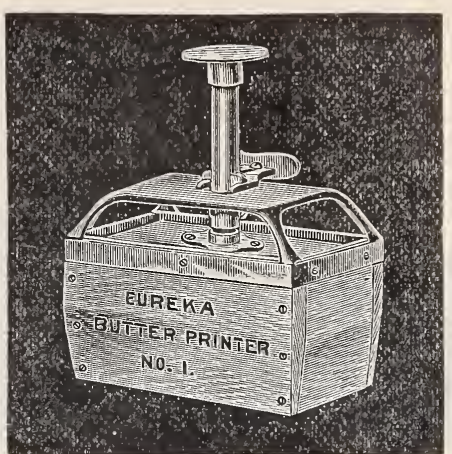

Eureka No. 1.

The illustration shows No. 1 Printer, the only difference in the two being that the No. 2 has no extra heavy gun metal band around the top.

The process of printing is very rapid. Gives accurate weight when rightly adjusted. Prints pounds $45 / 8 \times 2 \frac{1}{2} \times 2 \frac{3}{8}$ inches square; also half pounds $35 \% 8 \times 2 \frac{1}{2} \times 13-16$ inches.

It is made of close-grained hard wood, with gun metal, nickel top and trimming.

Price, with plain (uncarved) print block, print pounds or half pounds..........\$4.50

\section{Eureka No. 2.}

With plain (uncarved) print blocks to print pounds $4 \frac{5}{8} \times 2 \frac{1}{2} \times 2 \frac{3}{8}$, or halt pounds $45 / 8 \times$ $21 / 2 \times 13-16 \ldots \ldots \ldots \ldots \ldots \ldots \ldots \ldots \ldots . \ldots \ldots$

I. X. L. Self-Gauging.

The I. X. L. is one of the most popular Printers in the market. It is designed not only to print the butter, which it does very neatly and quickly, but also gauges it into prints of accurate weight.

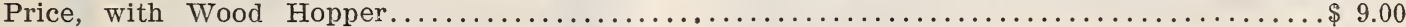

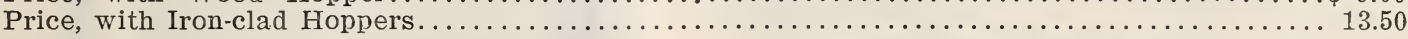

\section{Lafayette.}

The Lafay et $t$ e Printer is also selfgauging and is largely used in creameries. It fits into a table, as shown in cut, so the top of Print is level with top of table.

Price, without Table ............\$ 9.00

Price, with $\mathrm{Table}$

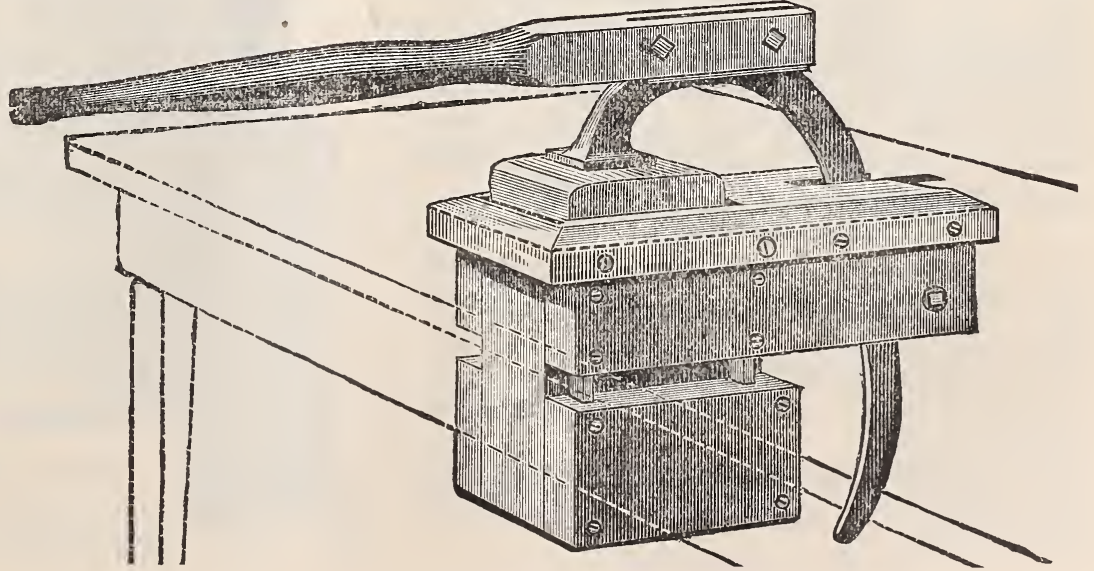




\section{BUTTER PRINTERS-Continued.}

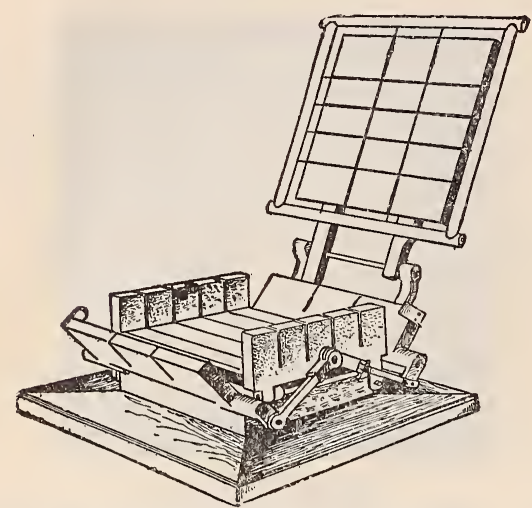

The American Butter Printer.

This is a new printer, very unique in design. It is easy to manipulate. Prints rapidly and leaves the butter in good shape, eicuer to wrap or put in cooling room.

This machine is just what the name implies, a printing and weighing machine, making each print of accurate weight and of a perfectly true and uniform style.

Each machine is supplied with four following boards or trays, which are used in removing the butter from the machine, and, if desired, butter can be left on these and placed in the refrigerator to thoroughly harden before being wrapped for shipment.

\section{Print Boards.}

We are prepared to make carved print boards to go with the American printer, of either names, initials or monograms, for which we make a nominal charge. The new feature in this respect is that the letters are raised on the wood instead of being cut into the wood, thus pressing the letters into the butter instead of raising on same. Any one accustomed to print butter will at once see the advantage of this, as the design will not become obliterated in packing and shipment.

Each machine, before being sent out, is tested and adjusted in every particular, so that customers ordering them need have no fear whatever of their not working properly.

\section{Sizes and Prices.}

10-1b. American Printer, creamery size... .\$20.00 15-1b. American Printer, creamery size... 25.00 20-1b. American Printer, creamery size... 27.50 25-1b. American Printer, creamery size... 30.00

Size of print, $2 \frac{1}{2} \times 2 \frac{1}{2} \times 4 \frac{5}{8}$. Special sizes made to order.

Each Factory Printer sent complete with four trays, one Butter Packer, one Butter Ladle and one Trimmer.

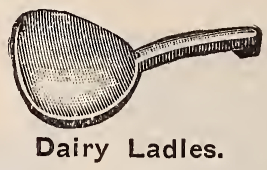

Made in Three Sizes.

Small, each.....................\$ \$0.25

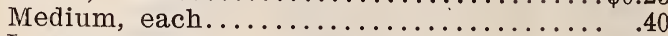

Large, each $\ldots \ldots \ldots \ldots \ldots \ldots \ldots \ldots \ldots \ldots \ldots \ldots \ldots \ldots \ldots . .50$

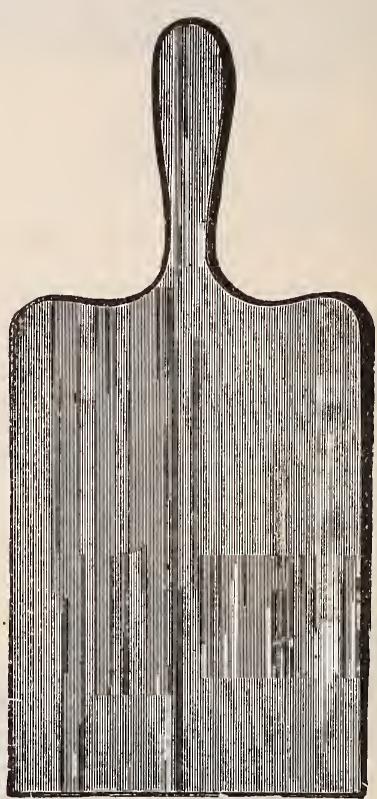

Factory Ladles.

3 in. wide each......\$ \$0.15

$31 / 2$ in. wide, each........ .20

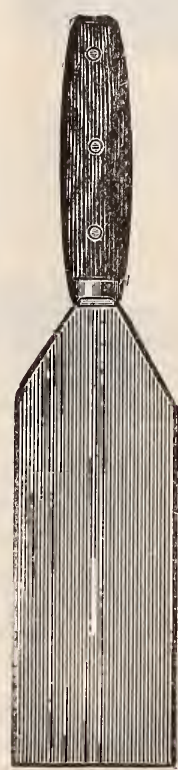

5 in. wide, each......... .25

10 in. wide, each....... .40

\section{Butter Spades.}

Steel.

Wooden Handle, 8-in. Steel Blade, $\mathrm{N}$ i c k e 1 Plated.

Price, each......\$1.00

Wood-Long Handles.

Price, each......\$0.50

Butter Packer.

The best Packer on the market. Turned from one piece of Seasoned Maple.

Price. each.......\$0.75 


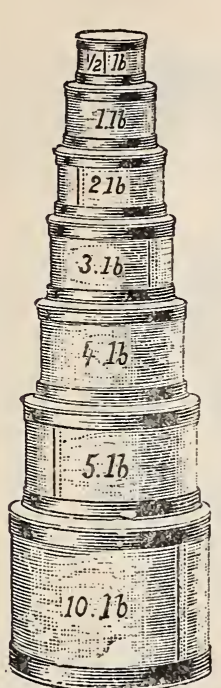

\section{Bradley Butter Boxes.}

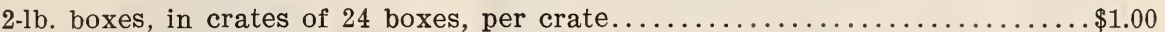

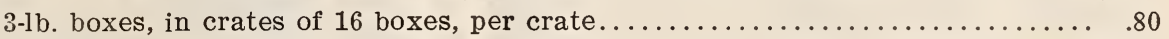

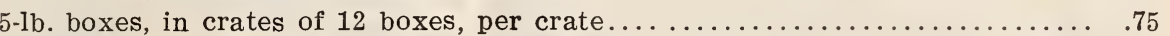

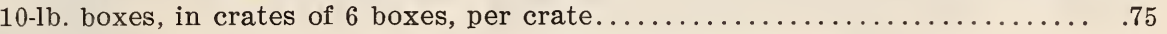

\section{Best Grade Poplar.}

Top, sides and bottom $3 / 8$ thick and ends $5 / 8$ thick, with hand holes.

54-lb., each......\$0.19

30-1b., eacn....... .15

24-lb., each...... .14

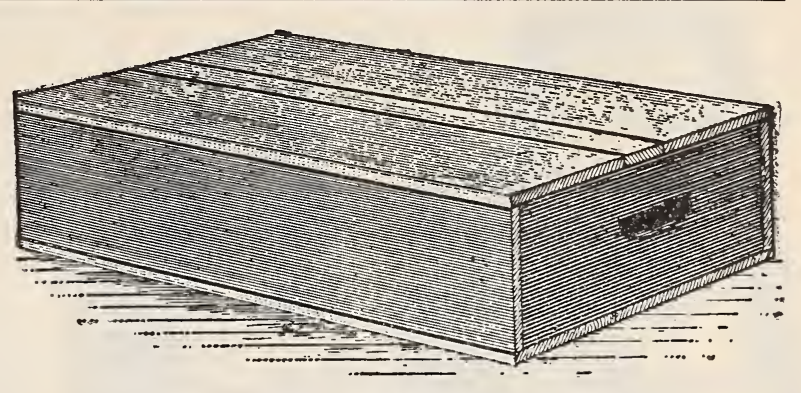

Print Butter Bcxes--Knock Dciwn.

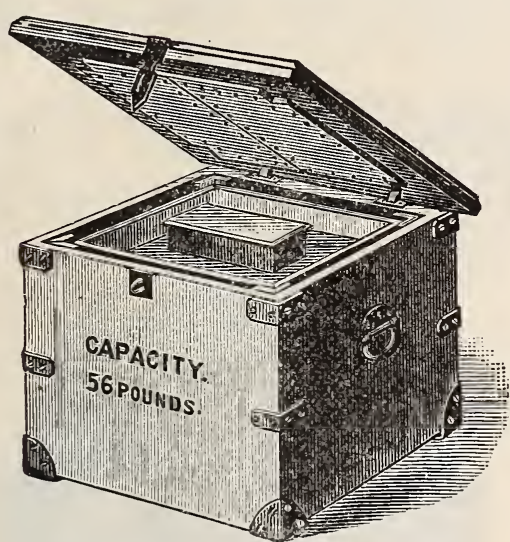

Refrigerator Shipping Boxes.

20-lb., each.....\$3.75

30-1b., each..... 4.25

56 -1b., each..... 5.00

80 -lb., each..... 5.50

40 -1b., each..... 4.75

96 -lb., each....6.6.00

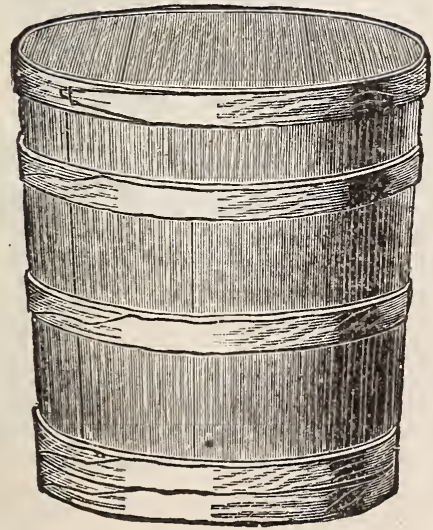

Butter Tubs.

Per Doz.

Per Doz.

10-lb. Spruce Tubs, $\$ 1.80 \quad 30$-lb. Spruce Tubs, 3.25 20-1b. Spruce Tubs, 2.60 50-1b. Spruce Tubs, 4.00

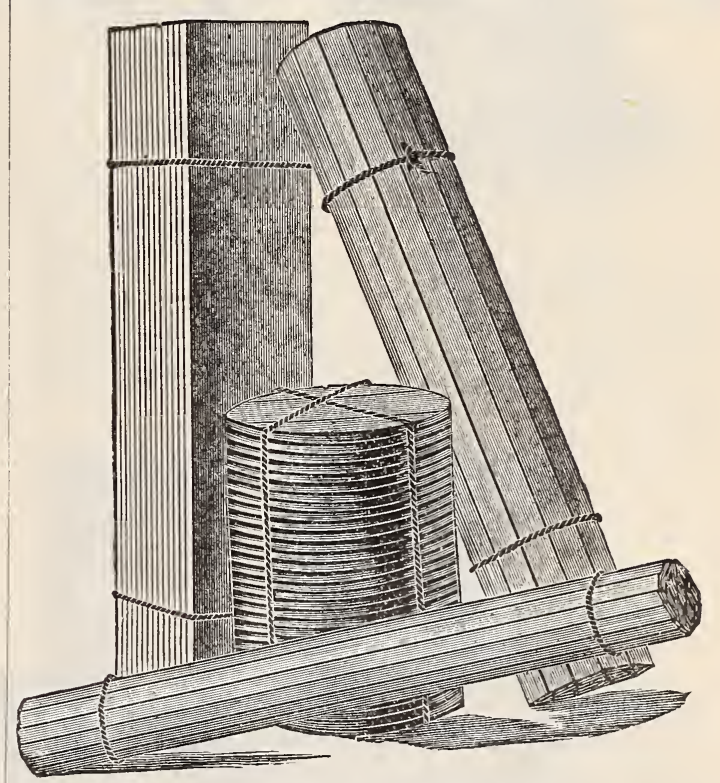

Cheese-Box Material.

In sets consisting of headings for bottom and cover, body hoop, bottom band and cover rim.

$7 \times 15 \ldots 12 \mathrm{c} \quad 7 \times 15 \frac{1}{2} \ldots 121 / 2 \mathrm{c} \quad 7 \times 17 \ldots . .13 \mathrm{c}$ $10 \times 17 \ldots 13 \mathrm{c} \quad 12 \times 12 \ldots 13 \mathrm{c} \quad 12 \times 15 \ldots 13 \mathrm{c}$ $12 \times 15 \frac{1}{2} \ldots 13 \frac{1}{2} \mathrm{c} \quad 12 \times 17 \ldots 14 \mathrm{c}$

Made-up Boxes, 4c Additional.

\section{Scale Boards.}

Per bundle ...................\$3.25

\section{Parchment Paper.}

Air-proof, Water-proof, Grease-proof, Tasteless and Odorless. Does not stick to the butter. It is better and cheaper than cloth for wrapping butter.

Packages of 500 sheets, $8 \times 11$, per package. . $\$ 0.50$ Packages of 1,000 sheets, $8 \times 11$, per package, .90 In lots of 5,000 or more, $8 \times 11$, per thousand, .80

Continued Next Page. 


\section{PARCHMENT PAPER-Continued.}

In sheets $24 \times 36$, per quire............ .25

In sheets, $24 x 36$, per ream.......... 4.50

In rolls, 14 inches wide, per lb.......... .18

In rolls, 24 inches wide, per lb......... .18
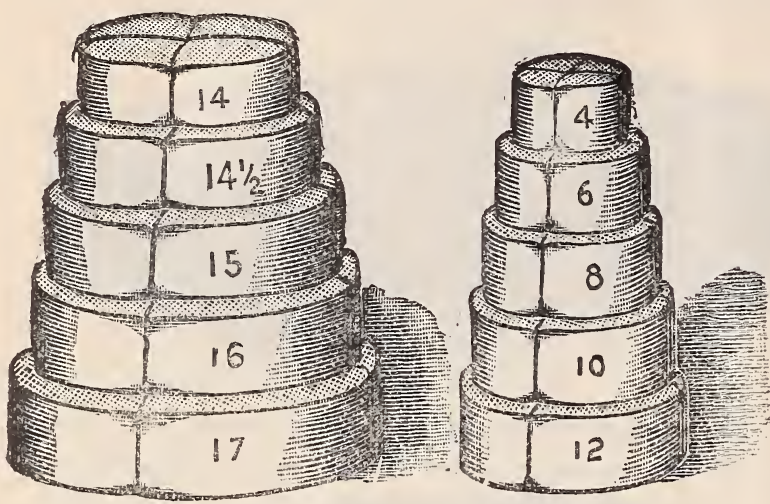

Circles-Cloth and Parchment.

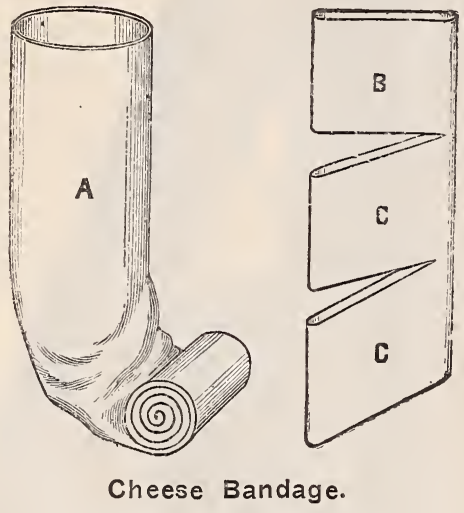

Lapham's Seamless.

The Best-the Cheapest-the Most Convenient to Use.

Trade mark is on every piece and we guarantee perfection of weave and accuracy of sizes. Made of a heavy grade of bleached cloth. No waste in any way, as bandages can be cut any desired length.

$$
\text { Per Yd. }
$$

Young Amer., 7 in., 4c 14 inches wide...5 $\frac{1 / 2}{2} \mathrm{c}$ $14 \frac{1}{2}$ inches wide, $5 \frac{1}{2} \mathrm{c}$

Note.-The 7-inch, or Y. A. Bandange, is woven in three parallel tubes, and the 11 and 12inch in two parallel tubes. The price given in each case is per yard of single tube.

\section{Cheese Cloth.}

36 inches wide, bleached, per yard.....\$0.06 Full bolts (50 to 60 yards), per yard... . .05 1/2

\section{Linen Strainer Cloth.}

76 inches wide, heavy, unbleached, per yard, 50c
We can print parchment wrappers with either blue or black ink, guaranteed not to run or come off on butter, for 50 cents per 1,000 for a single 1,000 , or 40 cents per 1,000 in lots of 2,000 or more.

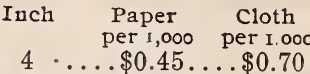

$$
\begin{aligned}
& 41 / 2 \ldots .50 \ldots .85 \\
& 5 \quad \ldots .55 \ldots .10 \\
& 51 / 2 \ldots .65 \ldots .1 .30 \\
& 6 \ldots .75 \ldots .45 \\
& 61 / 2 \ldots .90 \ldots 1.65
\end{aligned}
$$

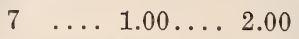

$$
\begin{aligned}
& 71 / 2 \ldots 1.20 \ldots 2.50 \\
& 8 \ldots 1.35 \ldots 2.75 \\
& 81 / 2 \ldots 1.50 \ldots 3.00 \\
& 9 \ldots 1.70 \ldots 3.35 \\
& 91 / 2 \ldots .91 .90 \ldots 3.75 \\
& 10 \quad \ldots \quad 2.10 \ldots .4 .20
\end{aligned}
$$

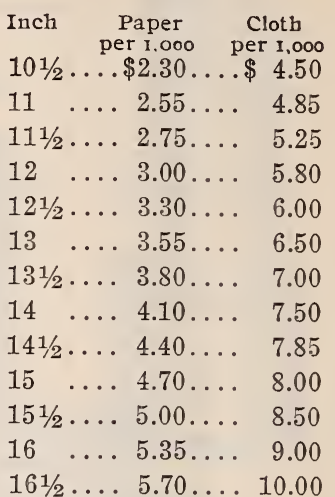

\section{Aprons.}

Oiled Canvas, medium weight........\$1.00 Oiled Canvas, extra heavy............ 1.25 Rubber, medium size................................... 1.50 Rubber, large size, heavy........... 2.00

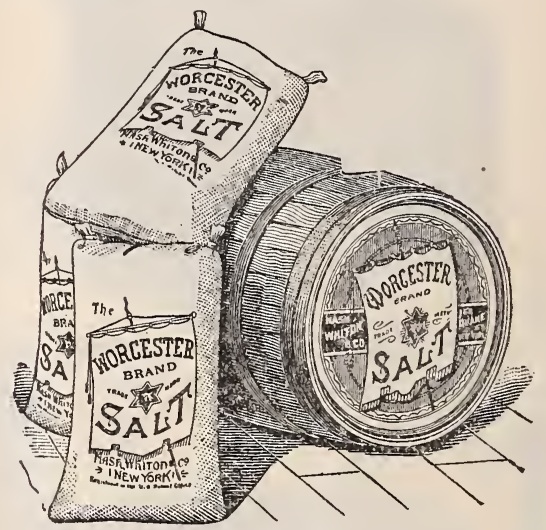

Salt.

To make good butter requires the use of a good salt.

Worcester is the acknowledged standard among progressive butter makers. Endorsed and recommended by prominent creamery men of the leading dairy districts.

Use Worcester and you will never have that "fishy taste" in your butter.

Especially recommended for butter that is to be put in storage.

We are distributing agents for this wellknown brand of salt and are in a position to make shipments of single barrels or carload lots.

Put up in 14-lb. sacks, 56-lb. linen bags and 320 -lb. barrels.

Don't forget to include "Worcester" in your next supply order.

14 -lb. sacks..................... \$0.35

56 -lb. bags ......................... 1.00

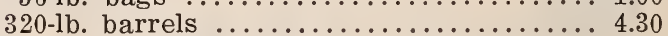
Special prices on large lots. 


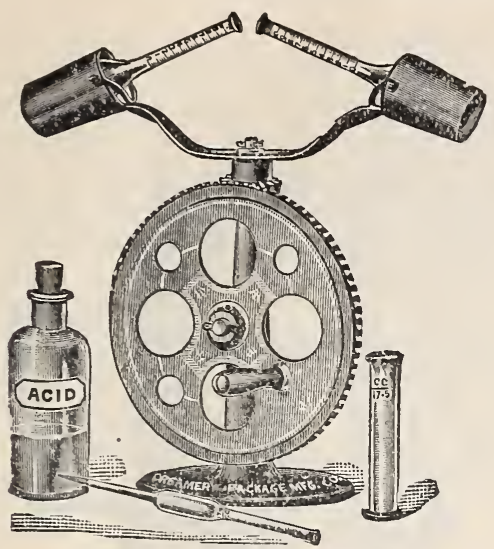

Babcock Testers-Ideal.

Is a wonderfully compact and simple machine. Designed especially for farmers and others who wish to test their cows at a light expense. A milk tester at so low a price that it is within the reach of all. An absolute umpire as to the value of a cow for dairy pur. poses.

With each machine is furnished necessary glassware and acid sufficient for a number of tests.

Prices.

2-Bottle, complete, each............\$3.50

4-bottle, complete, each........... 4.50

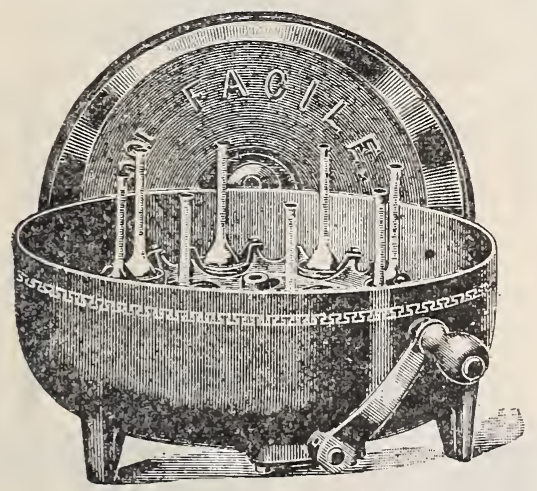

Facile-Hand Tester.

Handsome Cast Iron Case and Cover, Cut Spur and Worm Gearing, Malleable Iron Bottle Carrier, Seamless Brass Swinging Pockets for holding Test Bottles, enclosed Gearing. Bottles Perfectly Horizontal when Rotating. Turns Easily and Runs Smoothly and Noiselessly at a very High Speed.

6-Bottle Machine .................\$ 9.00

8-Bottle Machine ....................... 10.00

10-Bottle Machine ................ 12.00

Prices include full set of glassware, comprising test bottles, pipette and acid measures; also test bottle brush and bottle of acid.

Facile-Steam Turbine Tester.

The "Facile" Steam Turbine Tester, made in one size only.

24 bottles, Price..................\$30.00

This is the most popular and widely used Babcock Tester on the marliet. Used by all the leading State Experimental Stations. Fitted with Steam Gauge and Speed Indicator,
Reverse Steam Jet and Improved Swinging Pockets, insuring the bottles being horizontal when rotating-essential to a perfect reading.

Prices include a complete outfit of glassware and speed indicator.

The Facile are the best constructed Babcock Testers made, and are safe to run at a sufficient speed to give accurate tests.

\section{Testing Scales.}

For weighing samples of mill and cream for Babcock Test.

Per Set (Agate Bearings).......... $\$ 10.00$

\section{Milk Coolers and Aerators.}

$\mathrm{T}$ h e attention of milk d e a $\mathrm{l}$ er $\mathrm{s}$ and producers is called to the merits and claims of the Champion Milk Cooler-Aerator a n d Deodorizer.

It is simple in construction easily cleaned, low in price, strong and durable, a n d equally adapted for the use of still or running water.

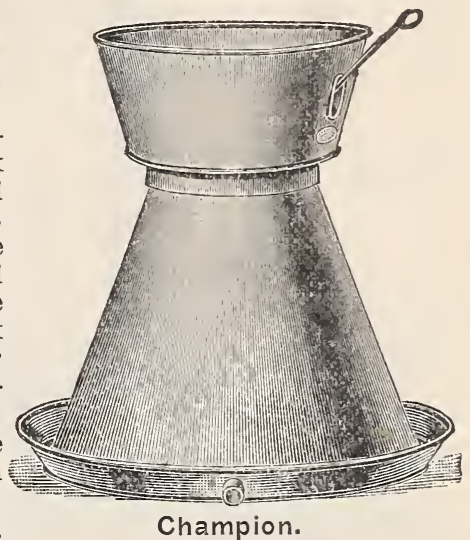

Sizes and Prices.

Nos. 1 and $2 \ldots \ldots \ldots \ldots 7.00$

No. $3 \ldots \ldots \ldots \ldots \ldots .8 .00$

No. $4 \ldots \ldots \ldots \ldots \ldots \ldots .10 .00$

B. \& W. Aerators, with

Funnel ........... 3.00

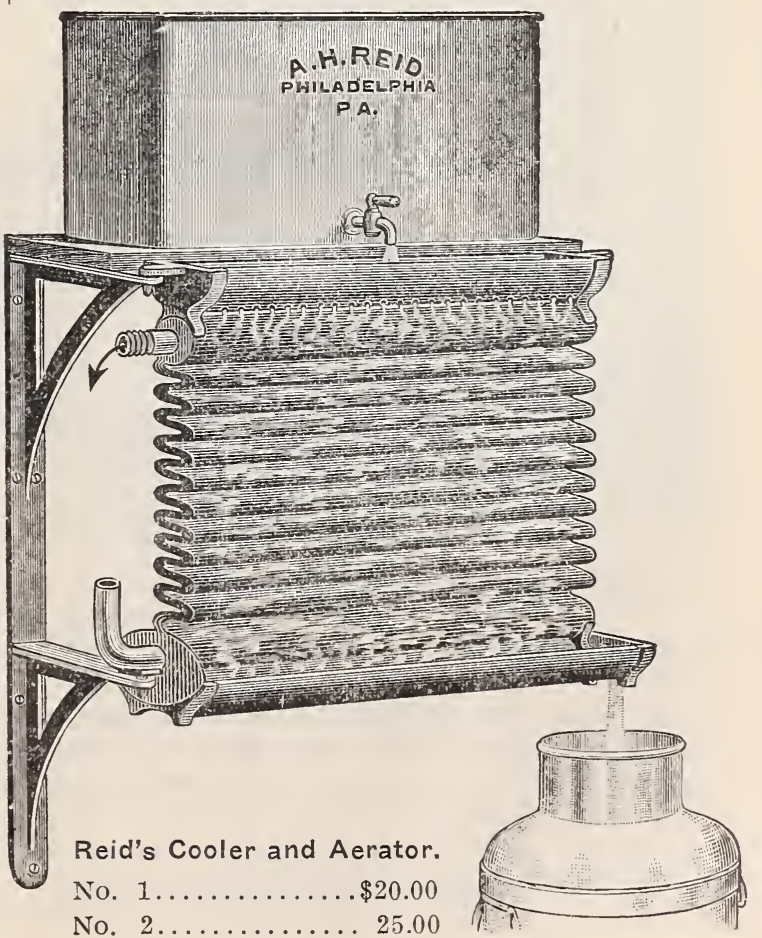




\section{Reid's Continuous Pasteurizer and Cream Cooler.}

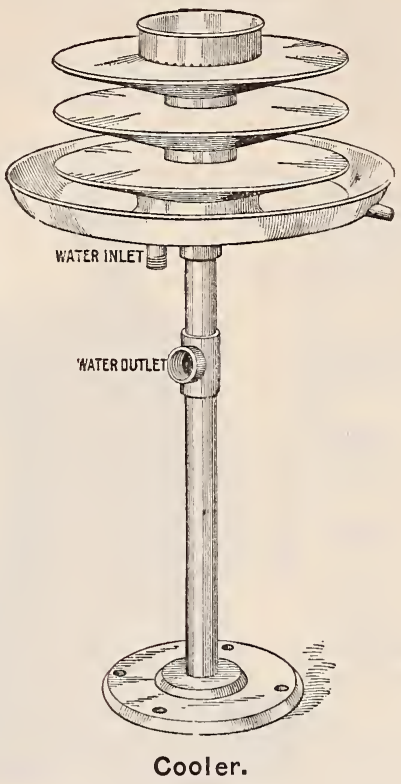

For cooling and aerating fresh milk or cream from the pasteurizer.

No. 1 , capacity 1,000 lbs. per hour. Price, $\$ 35.00$; with cover, $\$ 40.00$.

No. 2, capacity 2,000 lbs. per hour. Price, $\$ 50.00$; with cover, $\$ 58.00$.

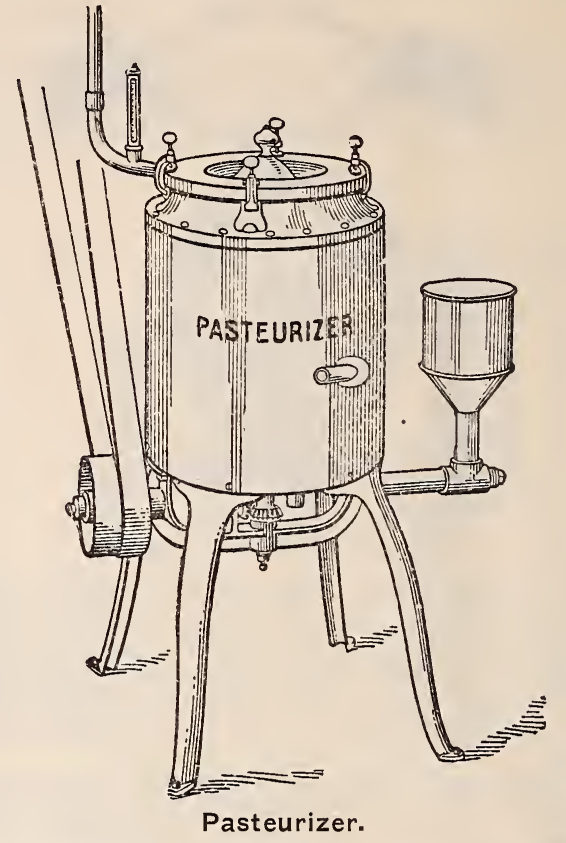

For pasteurization of cream as it comes from separator. Made of heavy copper, tinned on outside.

Will heat to any desired temperature and elevate milk to cooler at same time.

No. 1, capacity 600 lbs. per hour, price, complete ...................\$66.00 No. 2, capacity $1,000 \mathrm{lbs}$. per hour, price, complete ...................... \$88.00

For the pasteurization of milk and cream for commercial purposes we are convinced that the "Potts" Pasteurizer is the best, most complete and satisfactory Pasteurizer on the market at the present time.

The machine consists of two cylinders, one within the other, with a space on all sides of the inner cylinder of one inch, which space can be filled with hot or cold water, brine or steam, at will, by the use of valves and other convenient arrangements that are under the complete control of the operator.

The inner cylinder is made of tinned steel, while the outer one is a wood jacket.

Water and steam enter the machine by way of the hollow gudgeons upon which the machine revolves.

With the use of this machine, no energy is wasted, because of the fact that wood is a non-conductor of heat or cold, and steel a most perfect conductor.

If brine is used as a cooling medium the inner drum is made of heavily tinned copper, and one or more extra valves are provided.

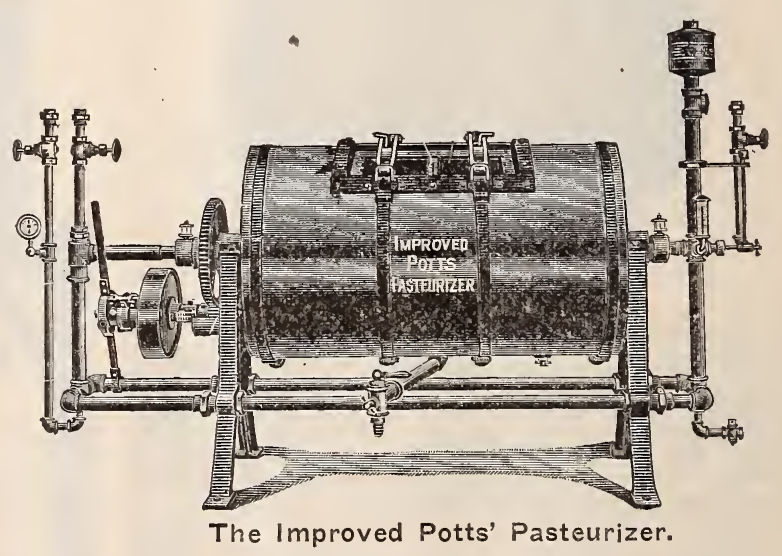

A specially designed friction pulley makes the manipulation of the machine very easy. Besides this, ingenious and easily manipulated covers and fastenings are provided. A system of circulating coils is fitted to the machine, the use of which causes little waste in using either the heating or cooling medium.

The machine is provided with special vents for both inner and outer drum. The outer vent designed to relieve the machine of extra pres- 
sure, the inner vent to carry off obnoxious gases, garlicy odors, and animal heat that pasteurization always tends to exclude.

Pasteurization in this machine imparts to the milk or cream no cooked or scalded flavor, but, on the contrary, gives the product a sweet prepared taste, besides adding greatly to its body, when directions are carefully and closely followed.

The Potts' Pasteurizer is absolutely air-tight, so that the product can not be exposed to the air at any time during the operation, and if drawn off in sterilized bottles directly from the Pasteurizer, the milk or cream will keep for

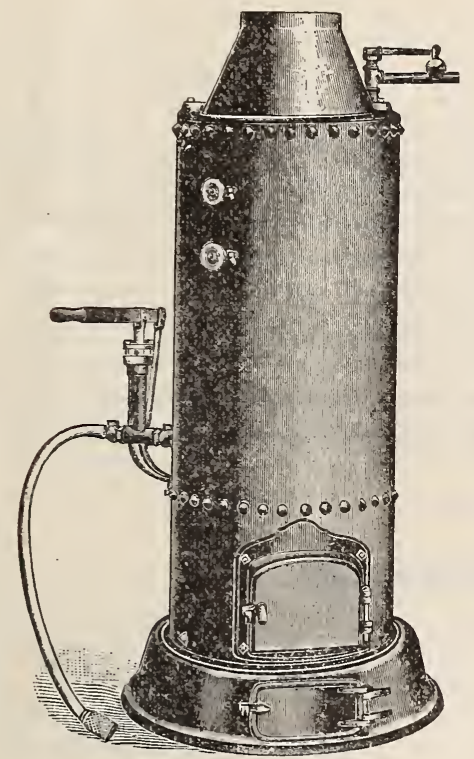

Eureka Boiler or Steam Feed Cooker.

This is a reliable farm boiler for cooking feed, heating water, etc. They are made from boiler iron and have regular lap-welded boiler flues, making them durable, rigid and strong in all their parts, and will last, with ordinary care, a lifetime. They are well riveted and calked, and are capable of standing an hydraulic pressure of 150 pounds to the square inch, and are perfectly safe, carrying 100 pounds pressure.

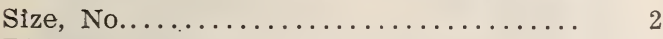

Diameter of shell, inches............. 19

Height of shell, inches.............. 44

No. of 2 -inch flues.................. 13

Length of boiler, over all, inches........ 58

Shipping weight, pounds............ 370

Net Price..................... \$30.00

Steam gauges and water column, extra... 5.00

The trimmings include two gauge cocks, blow-off valve, pump for supplying the boiler with water, safety valve, two feet six inches suction hose, three feet steam pipe, with valve two or three days longer than the same would if not pasteurized.

\section{Sizes and Prices.}

50 -gal., complete, with iron stands, thermometer, etc..............\$125.00

75-gal., complete, with iron stands, thermometer, etc............... 135.00

100 -gal., complete, with iron stands, thermometer, etc................ 150.00

150-gal., complete, with iron stands, thermometer, etc................ 175.00

200-gal., complete, with iron stands, thermometer, etc................ 200.00

F. O. B. Factory.

to convey steam to barrel or vat for cooking feed or boiling water.

\section{Boilers and Engines.}

When in need of anything in the line of Boilers or Engines, write us for specifications and prices before buying.

We carry all sizes in stock, and are in a position to make low prices on any size or style wanted.

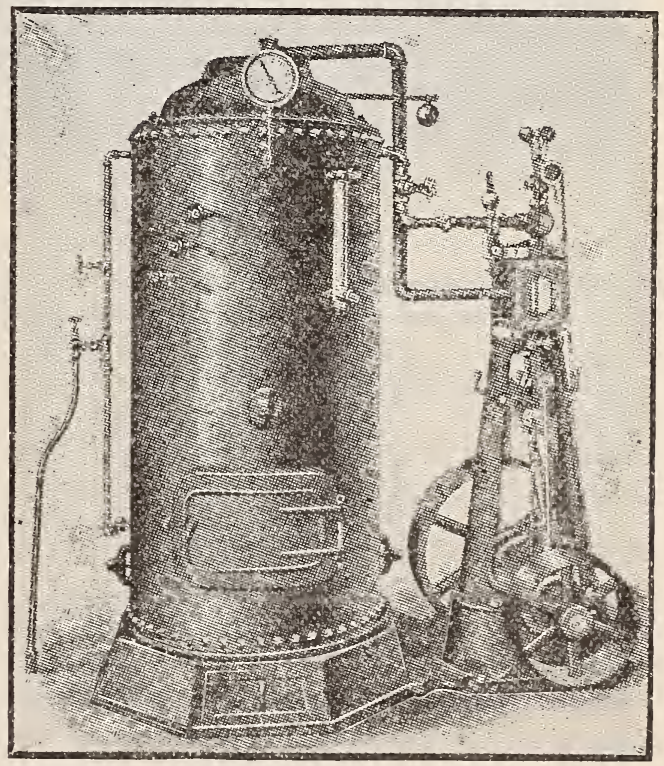

Combined Vertical Engine and Boiler.

The above illustrates our Combined Vertical Engine and Boiler, trimme $\mathrm{I}$ and piped complete, built in any size boiler from one and onehalf horse-power to sixteen horse-power, and engine one horse-power to fifteen horse-power. See specifications, page 64. We always furnish on independent bases unless otherwise ordered, but we make no extra charge for combining on one base when desired. 


\section{Specifications of Plain Vertical Boilers.}

\begin{tabular}{|c|c|c|c|c|c|c|c|c|c|c|c|}
\hline HORSE-POWER & $1 \frac{1}{2}$ & 2 & 3 & 4 & 5 & 6 & 8 & 10 & 12 & 14 & 16 \\
\hline Diameter of Boiler, in inches....... & 20 & 20 & 20 & 24 & 24 & 26 & 30 & 30 & 36 & 36 & 36 \\
\hline Height above base, in inches...... & 36 & 43 & 49 & 50 & 60 & 60 & 60 & 72 & 72 & 84 & 96 \\
\hline Diameter of furnace, in inches.......... & 16 & 16 & 16 & 21 & 21 & 22 & 25 & 25 & 30 & 30 & 30 \\
\hline Height of furnace, in inches.. & 18 & 18 & 18 & 18 & 18 & 22 & 24 & 24 & 24 & 28 & 32 \\
\hline Thickness of steel in shell... .. & $3-16$ & $1 / 4$ & $1 / 4$ & $1 / 4$ & $1 / 4$ & $1 / 4$ & $I / 4$ & $1 / 4$ & $1 / 4$ & $1 / 4$ & $1 / 4$ \\
\hline Thickness of steel in heads... & $1 / 4$ & $\frac{5}{16}$ & $1^{56}$ & $\frac{5}{16}$ & ${ }_{16}^{5}$ & $\frac{5}{16}$ & $\frac{5}{16}$ & $3 / 8$ & $3 / 8$ & $3 / 8$ & $3 / 8$ \\
\hline Thickness of steel in fire box.. & $1 / 4$ & $1 / 4$ & $1 / 4$ & $1 / 4$ & $1 / 4$ & $1 / 4$ & $1 / 4$ & $1 / 4$ & $5-16$ & $5-16$ & $5-16$ \\
\hline Length of tubes, in inches.. & 18 & 25 & 31 & 32 & 40 & 38 & 36 & 48 & 48 & 56 & 64 \\
\hline Number of 2 -inch tubes......... & 16 & 19 & 19 & 31 & 31 & 37 & 43 & 43 & 55 & 55 & วั5 \\
\hline Weight of boiler without trimmings or fixtures.. & 325 & 430 & 530 & 640 & 750 & 840 & 1010 & 1180 & 1520 & 1800 & 2280 \\
\hline Weight of boiler complete.... & 475 & 560 & 620 & 890 & 1060 & 1300 & 1550 & 1650 & 2350 & 2540 & 3000 \\
\hline Outside diameter of stack opening, inches. & $81 / 2$ & $81 / 2$ & $81 / 2$ & 10 & 10 & & $12 \frac{1}{2}$ & $12 \frac{1}{2}$ & 16 & 16 & 16 \\
\hline Height from floor to top of hood. in inches.... & 50 & 54 & 60 & 66 & 76 & 76 & 76 & 94 & 98 & 108 & 120 \\
\hline
\end{tabular}

CAST FIXTURES.-Base, hood, fire door and grates.

TRIMMINGS.-Injector fitted with pipe and valves, steam gauge, water gauge, gauge cocks, safety valve and blow-off.

All boilers above 26 inches in diameter have vertical seams double riveted. They are made of flange steel 60,000 lbs. T. S.' and are tested to $160 \mathrm{lbs}$. hydraulic pressure.

Dimensions of Vertical Engines.

\begin{tabular}{|c|c|c|c|c|c|c|c|c|c|c|}
\hline RATED HORSE-POWER & 1 & 2 & 3 & 4 & 5 & 6 & 8 & 10 & 2 & 15 \\
\hline Cylinder $\left\{\begin{array}{l}\text { Bore } \ldots \ldots \ldots \ldots \ldots \\
\text { Stroke.......................... }\end{array}\right.$ & $\begin{array}{c}21 / 2 \text { in. } \\
3 \text { in. }\end{array}$ & $\begin{array}{l}3 \text { in. } \\
5 \\
\text { in. }\end{array}$ & $\begin{array}{l}31 / 2 \text { in. } \\
5 \text { in. }\end{array}$ & $\begin{array}{l}4 \text { in. } \\
5 \text { iu. }\end{array}$ & $\begin{array}{l}41 / 2 \text { in. } \\
5 \text { in. }\end{array}$ & $\begin{array}{l}5 \text { in. } \\
71 / 2 \text { in. }\end{array}$ & $\begin{array}{l}6 \text { in. } \\
7 \frac{1}{2} \text { in. }\end{array}$ & $\begin{array}{l}71 / 2 \mathrm{in} . \\
8 \mathrm{in}\end{array}$ & $\begin{array}{l}71 / 2 \mathrm{in} . \\
9 \mathrm{in} .\end{array}$ & $10 \mathrm{in}$. \\
\hline Steam Pipe... & $3 / 8 \mathrm{in}$. & $1 / 2$ in. & $1 / 2$ in. & $3 / 4$ in. & $3 / 4$ in. & $1 \mathrm{in.}$ & $1 \mathrm{I} / 4 \mathrm{in}$. & $1 \frac{1}{2}$ in. & $1 \frac{1}{2} \mathrm{~m}$. & $1 \frac{1}{2} \mathrm{in.}$ \\
\hline Exhaust Pipe... & $1 / 2$ in. & $3 / 4$ in. & $3 / 4 \mathrm{in}$. & $1 \mathrm{in.}$ & $1 \mathrm{in.}$ & $11 / 4 \mathrm{in}$. & $1 \frac{1}{2} \mathrm{in}$. & 2 in. & 2 in. & 2 in. \\
\hline Revolutions per minut & 400 & 350 & 3 & 300 & 300 & 250 & 200 & 200 & 180 & 180 \\
\hline Belt Pulley $\left\{\begin{array}{l}\text { Diameter.. } \\
\text { Face. ..... }\end{array}\right.$ & $\begin{array}{c}6 \mathrm{in} . \\
3 \mathrm{I} / 4 \mathrm{in}\end{array}$ & $\begin{array}{l}10 \text { in. } \\
41 / 2 \text { in. }\end{array}$ & $\begin{array}{l}10 \text { in. } \\
41 / 2 \text { in. }\end{array}$ & 12 in. & $\begin{array}{l}12 \text { in. } \\
5 \text { in. }\end{array}$ & $\begin{array}{l}11 \text { in. } \\
61 / 2 \text { in. }\end{array}$ & $\begin{array}{l}14 \text { in. } \\
61 / 2 \text { in. }\end{array}$ & $\begin{array}{l}16 \text { in. } \\
71 / 2 \text { in. }\end{array}$ & $\begin{array}{l}18 \mathrm{in} . \\
81 / 2 \text { in. }\end{array}$ & \\
\hline Governor Pulley $\left\{\begin{array}{l}\text { Diameter. } \\
\text { Face....... }\end{array}\right.$ & $\begin{array}{c}3 \mathrm{in} . \\
11 / 4 \mathrm{in}\end{array}$ & $\begin{array}{c}4 \mathrm{in} . \\
1 \mathrm{i} / 2 \mathrm{in} .\end{array}$ & $\begin{array}{l}4 \text { in. } \\
11 / 2 \text { in. }\end{array}$ & $\begin{array}{l}15 / 8 \mathrm{in} . \\
11 / 2 \mathrm{in.}\end{array}$ & $\begin{array}{l}45 / 8 \mathrm{in} . \\
11 / 2 \mathrm{in} .\end{array}$ & $\begin{array}{l}55 / 8 \text { in. } \\
13 / 4 \text { in. }\end{array}$ & $\begin{array}{l}61 / 8 \text { in. } \\
13 / 4 \text { in. }\end{array}$ & $\begin{array}{l}9 \text { in. } \\
2 \text { in. }\end{array}$ & $\begin{array}{l}9 \text { in. } \\
2 \text { in. }\end{array}$ & $\begin{array}{l}9 \mathrm{in.} \\
2 \mathrm{in.}\end{array}$ \\
\hline Floor Space, inches. & $14 \times 26$ & $18 \times 20$ & $18 \times 20$ & $18 \times 20$ & $18 \times 20$ & $20 \times 22$ & $20 \times 22$ & $22 \times 24$ & $22 \times 21$ & $22 \times 24$ \\
\hline Height to top cf Cylinder. & $30 \mathrm{in.}$ & $3 \mathrm{ft} .6$ in. & $3 \mathrm{ft} .6 \mathrm{in}$. & $3 \mathrm{ft} .6$ in. & $3 \mathrm{ft} .8 \mathrm{in}$. & $4 \mathrm{ft} .8$ in. & 4 ft. 10 in. & 5 ft. 2 in. & 5 ft. 3 in. & 5 ft. $t$ in. \\
\hline Weight & $170 \mathrm{lbs}$. & $275 \mathrm{lbs}$ & $300 \mathrm{lbs}$. & $125 \mathrm{lbs}$. & $500 \mathrm{lbs}$. & $7001 \mathrm{bss}$. & $850 \mathrm{lbs}$. & $1250 \mathrm{lbs}$. & $1400 \mathrm{lbs}$. & $1500 \mathrm{lbs}$ \\
\hline Balance Wheel $\left\{\begin{array}{l}\text { Diamete } \\
\text { Face... } \\
\text { Weight }\end{array}\right.$ & $\begin{array}{l}13 \mathrm{in} . \\
31 / 2 \mathrm{in} . \\
3.5 \mathrm{lbs} .\end{array}$ & $\begin{array}{l}15 \mathrm{ing} \\
4 \mathrm{int} \\
\text { t5 } \mathrm{lbs} .\end{array}$ & $\begin{array}{l}15 \mathrm{in} . \\
4 \mathrm{in.} \\
45.5 \mathrm{ibs} .\end{array}$ & $\begin{array}{l}17 \mathrm{in.} \\
41 / 2 \mathrm{in.} \\
65 \mathrm{lbs} .\end{array}$ & $\begin{array}{l}17 \mathrm{in} . \\
41 / 2 \mathrm{in} . \\
100 \mathrm{lbs} .\end{array}$ & $\begin{array}{l}24 \mathrm{in} . \\
6 \mathrm{in.} \\
170 \mathrm{lbs} .\end{array}$ & $\begin{array}{l}24 \mathrm{in.} \\
6 \mathrm{ing} \\
170 \mathrm{lbs} .\end{array}$ & $\begin{array}{l}30 \mathrm{in} . \\
63 / 4 \mathrm{in} . \\
180 \mathrm{lbs} .\end{array}$ & $\begin{array}{l}30 \mathrm{in} . \\
63 / 4 \mathrm{in} . \\
180 \mathrm{lbs} .\end{array}$ & $\begin{array}{l}35 \text { in. } \\
71 / 4 \text { in. } \\
350 \mathrm{lbs} .\end{array}$ \\
\hline Diameter of Shaft & $11 / 8$ in. & $1 \frac{1}{2}$ in. & $1 \frac{1}{2} \mathrm{in}$. & $11 / 2$ in. & $1 \frac{1}{2} \mathrm{in}$. & $1_{16}^{15}$ in. & $1_{16}^{15}$ in. & $23 / 8$ in. & $23 / 8$ in. & $23 / 8 \mathrm{in}$. \\
\hline
\end{tabular}

TRIMMINGS.-The prices include governor, governor pulley and belt, throttle valve, oil cups, cylinder lubricator, belt wheel, balance wheel and air cock. 


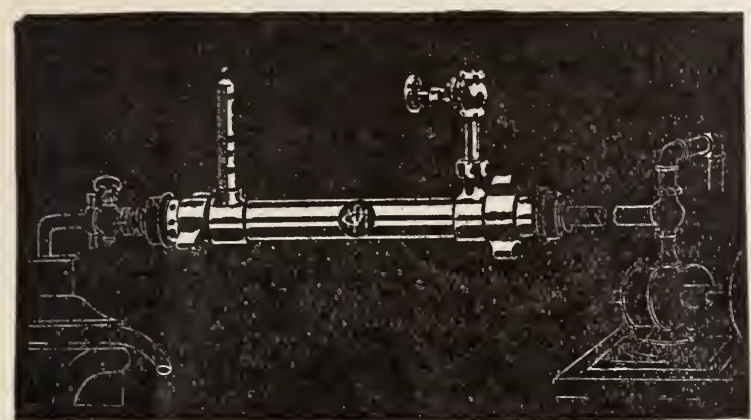

Ideal Heater.
Milk Heaters-Open Tempering Vat.

Made of Galvanized Iron on outside, with XXXX Tin Lining. Water space at sides and bottom. Fitted with Steam Connection.

For one Separator, each.........\$7.50

\section{Ideal Heater.}

Can be used either with pump or gravity system. Simplest heater on the market. Easy to clean and talies up but very little space. Fitted with steam connection and thermometer. Capacity, 6,000 pounds per hour.

Price, each................. \$10.00

\section{Curtis Heater.}

This heater is made to meet the demand for something better than the heaters heretofore on the market. In construction it is made in cylinder form, the outside being of galvanized iron, while the inner lining is of heavy tin, the outer being a hot water jacket. Milk is heated by coming in contact with water jacket in a very thin sheet. No live steam enters the milk in any way, which is a great advantage over any other enclosed heater.

Can be used with either pump or gravity system.

Fitted with steam connections and thermometer.

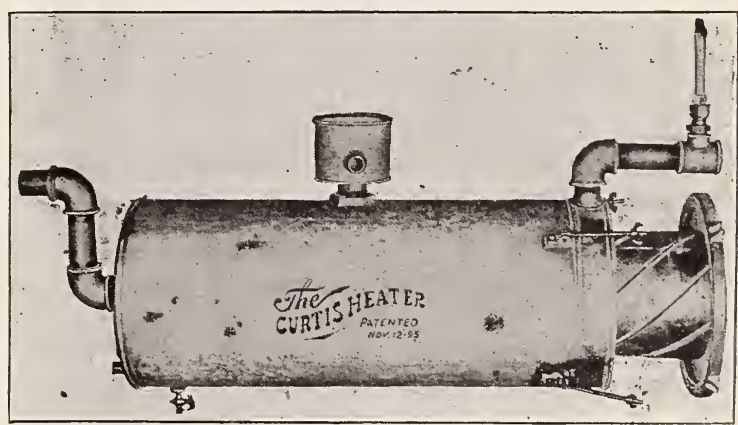

Curtis Heater.
No. 1 , capacity 2,000 pounds per hour, each $\ldots \ldots \ldots \ldots \ldots \ldots \ldots \ldots \ldots \ldots \ldots \ldots \ldots \ldots \ldots$
No. 2, capacity 3,000 pounds per hour, each $\ldots \ldots \ldots \ldots \ldots \ldots \ldots \ldots \ldots \ldots . \ldots \ldots$

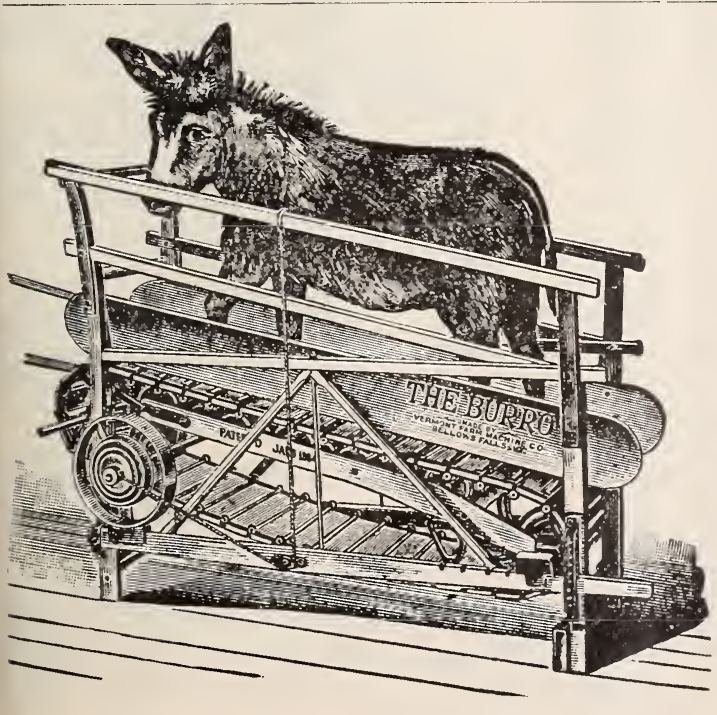

\section{Burro Power.}

This power is designed for animals weighing from 200 to 400 pounds. It has an adjustable platform and is also fitted with a speed governer.

Price,....................... \$ \$45.00

Prices and specifications for dog power sent on application. 


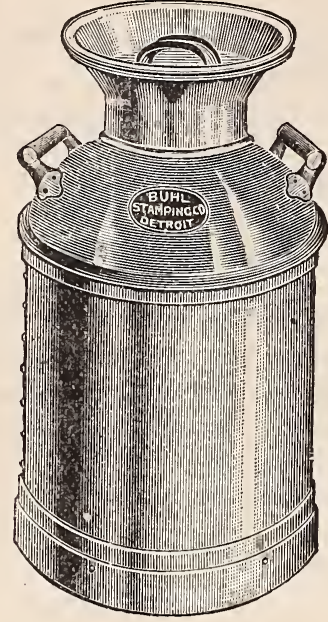

SHIPPING CANS.

We handle the genuine "Buhl," and guarantee every can to be perfect. They are, without doubt, the best made can on the market and give better satisfaction than the cheaper grades.

\section{Buhl New York Pattern.}

5-gallon Cans, 14 lbs............. \$2.40

10-gallon Cans, 22 lbs................ 2.75

\section{New York Pattern.}

10-gallon Cans, 22 lbs. $\$ 3.20$

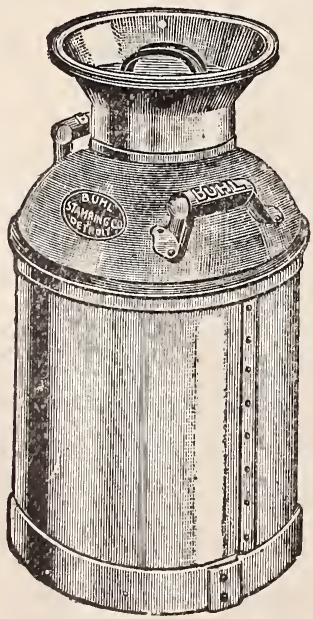

\section{Buhl lowa Pattern.}

5-gallon Cans, 12 lbs.

8-gallon Cans, $161 / 2$ lbs............. 2.50 10-gallon Cans, 18 lbs.

\section{Buhl Jersey Pattern.}

10-gallon Cans, $161 / 2$ lbs............\$2.50

5-gallon Cans

\section{Buhl Ohio Pattern.}

5-gallon Cans.................. $\$ 1.75$

10-gallon Cans

CITY DELIVERY CANS.

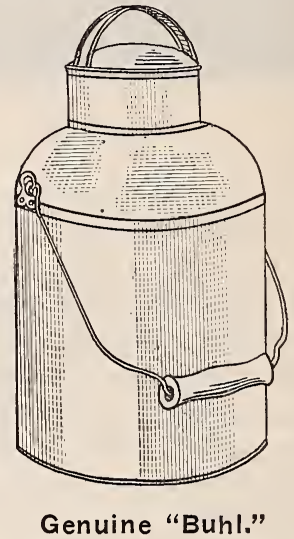

With either Bail or Side Handle.

2-quart Cans.................\$0.60

4-quart Cans.................... $\quad .70$

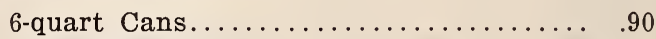

8-quart Cans...................... 1.10

10-quart Cans...................... 1.25

12-quart Cans....................... 1.40

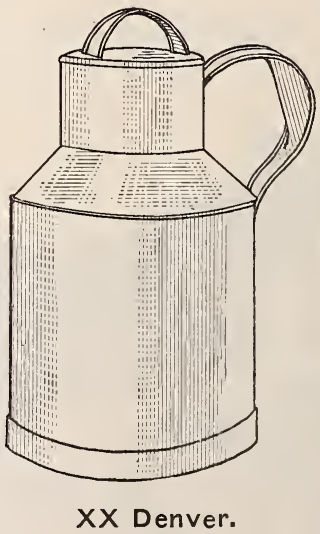

With either Bail or Side Handle.

2-quart Cans.................\$0.50

4-quart Cans.................... .60

8 -quart Cans....................... 85

12-quart Cans.................... 1.00

20 -quart Cans..................... 1.50 


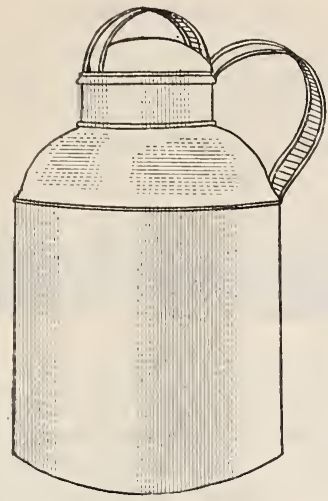

I. C.

With either Bail or Side Handle.

1 -quart Cans ................... \$0.10

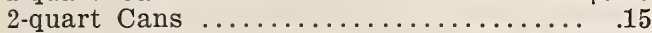

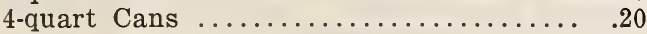

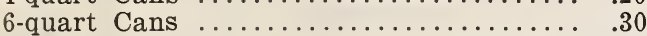
8-quart Cans ....................40

Special prices on all Delivery Cans when ordered in dozen lots or over.

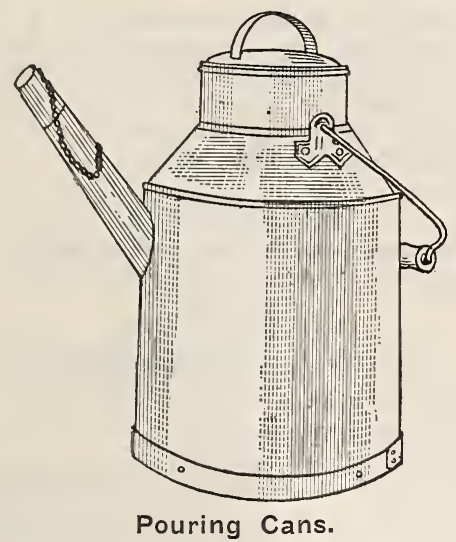

2-gallon, each..................\$1.50

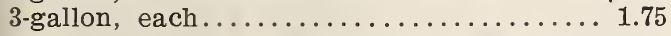

\section{Common Sense Setting Cans.}

20-quart Can, with Cover, each........\$0.60 Per dozen ....................... 6.00 14-quart Cans, with Cover, each........ .50 Per dozen ...................... 5.00

PAILS.

Iron-Clad Tin, Plain.

10-quart, each .................\$0.50

12-quart each ................... 60

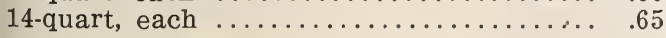

The Denver Strainer.

10 -quart, each .................. $\$ 0.50$

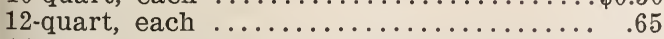

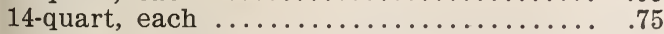

The Gem Strainer.

10-quart, each ................\$0.60

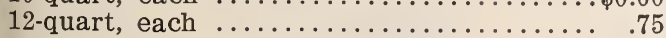

Flat Side Curd Pails.

Extra heavy tin, each............\$1.50

\section{Calf Weaners.}

For preventing calves and cows from sucking themselves or each other. It is no hindrance to drinking or eating.

Tylers ...............35c

Hoosier...........50c

Shaw ...............

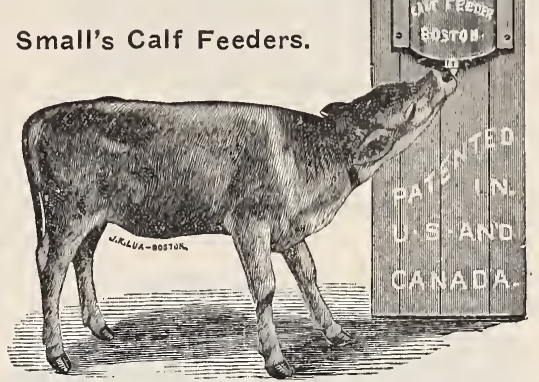

This new article of manufacture was designed and has been perfected by the inventor for feeding milk to young calves in a natural way before they are old enopgh to eat and drink otherwise, and is to the calf what the nursing bottle is to the babe, a substitute for nature.

Its chief merits are not only in the convenience, but in the sleek, thrifty healthy calves it produces, as they suck their food slowly in the natural way, producing the gastric juices as in nature, and the calf is never stunted or set back, as they are when taught to drink, but grow rapidly from the time they are put to the Feeder.

Price, each .................. \$2.50

Nipples, $25 \mathrm{c}$ each; per dozen............ 2.50

\section{PRATT'S FOOD.}

In use over thirty years.

The Original Stock and Poultry Food of America.

The greatest of Animal and Poultry Regulators.

Sold in 40,000 towns in the United States, and fed in five different continents.

12-pound package ....................75c

It makes horses robust and healthy. Cures worms, grubs and botts; makes the coat glossy, creates perfect digestion; purifies the blood; and regulates the kidneys, etc.

Cows will not slink their calves. They will give more milk and butter of richer quality, and be strong and sturdy. Calves fed Pratt's Food grow quickly and healthy. Cattle raisers can fatten their stock for killing in half the time and cost by feeding Pratt's Food.

Hog Cholera is prevented and cured by its use. Hogs, young pigs and boars thrive when Pratt's Food is fed. It is the greatest eradicator of swine disease and most rapid hog-fattener on earth.

PRATT'S POULTRY FOOD cures chicken cholera, produces eggs, fattens poultry quickly for market; makes young chickens grow, and cures all poultry diseases. 5-pound package, 60 cents.

Valuable coupons in every package and bag.

Send for 64-page book, free.

Linseed Oil Meal and Cottonseed Meal for feeding all kinds of stock.

Rock and Stock Salt. 


\section{Rennet Extract.}

1-gallon bottles or jugs, original packages, per gallon .................. \$2.00 5 or 10 -gallon kegs, per gallon.......... 1.55

\section{Rennet Tabless.}

Rennet Tablets, per box 24, No. $2 \ldots \ldots \ldots \$ 0.50$ Rennet Tablets, per box 50, No. 2...... .90 Rennet Tablets, per box 200 , No. $2 \ldots \ldots \ldots 2.25$

\section{Rennet Test.}

Marschall's each................\$2.50 Most Practical Test in Use.

\section{Salt-Worcester.}

14-1b. sack ..................\$0.35

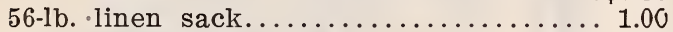
Per barrel, 320 lbs., net............... 4.30

\section{Scale Boards.}

Per bundle..$\ldots \ldots \ldots \ldots \ldots \ldots \ldots \ldots \ldots 3.25$

Tacks-Cheese Box.

Made of Swedish Iron.

8,10 or 12 ounce, per $1 \mathrm{~b} \ldots \ldots \ldots \ldots \ldots \ldots . . . \ldots$

\section{Waste-Cotton.}

White, per pound..................\$0.12

Colored, per pound.....................

\section{Washing Compounds.}

In 25-pound pails, per tb .........\$0.06

In 50 -pound kegs, per tb ...............

In barrels, per to...................... 05

Sal Soda, chemically pure........... .03

\section{Dairy Authorities.}

A B C in Cheese-Making, by J. H. Monrad, paper .......................\$0.50

A B C in Butter-Making, by j. H. Monrad, paper ....................... .50

American Dairying, Gurler, cloth........ 1.00 Cheese-Making (new), by Prof. J. W. Decker, cloth, 192 pages........... 1.75

Dairying for Profit, by Mrs. E. M. Jones,

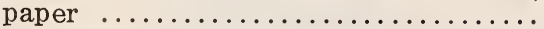

Dairy Messenger, Nos. 1 to 10 , containing series of articles, making a complete Handbook in Butter-Making......... 1.00

Handbook for Farmers and Dairymen, by $\mathrm{F}$. W. Woll, cloth.................. 1.75

Milk, Its Nature and Composition, C. M. Aikman..................... 1.25

Milk and Its Products, Prof. H. H. Wing, cloth ...................... 1.00

Milk Testing, A. Schoenman, cloth, 39

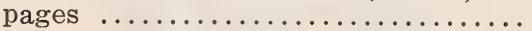

Modern Dairy Practice, Grotonfelt-Woll, cloth, 285 pages..................

Outlines of Dairy Bacteriology, Prof. H. L Russell ...................... 1.2

Pasteurization and Milk Preservation, J. H.

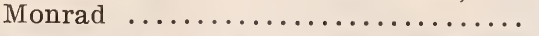

Testing Milk and Its Products, FarringtonWoll, the most complete work on the subject, cloth, 236 pages...........

Woll's Book on Silage, paper, 185 pages

\section{Computators.}

Schoenman's ................... \$2.00

Bentley's Lightning................ 5.00

Newton's ..................... 4.50

Calm's Cream ................... 2.50

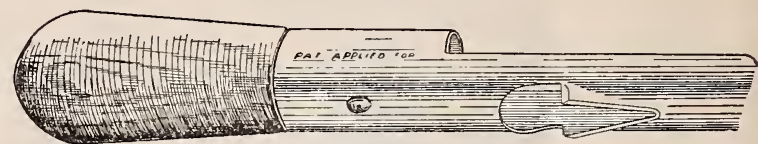

Wick's Calf Dehorners.

Something new, simple and effective for dehorning calves. Full instructions accompany each dehorner. Just what every stockman should have, so simple any one can use it.

Price, each.................... $\$ 1.00$

\section{Mops-Iron Heads.}

When rubber is worn out, can be removed and replaced by new one. Each mop is complete with rubber and wrench.

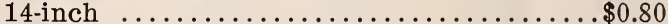

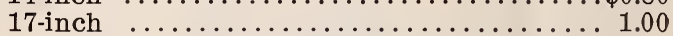

\section{Wood Heads.}

For those not caring to refill the mop-heads with rubber after it is once worn out, these will be found a serviceable mop. Heads are clear, hard wood, and the rubber is of pure gum.

14-inch, with single rubber, each.......\$0.35 12-in. with two rubbers, each.......... .75

\section{Extra Rubbers.}

Pure gum, for 14-inch iron head, each....\$0.25 Pure gum, for 17-inch iron head, each.... . .30

\section{Supplies-Acid.}

For Making Babcock Tests.

Per gallon, including jugs...........\$0.75

Per pound, in carboys................ .03

Carboys charged at, each............ 2.50

When returned, this is refunded, less freight charges.

Rope Belts for DeLaval or Sharples' Separators.

17 feet, 4 inches or 17 feet, 7 inches, two on a board.

Per pair .....................\$1.50

Per dozen .................... 8.50

\section{Butter Color.}

We are western agents for both Wells Richardson's Improved, Heller \& Merz Alderney and Hansen's Danish Butter Color. In ordering, state which is wanted.

4-oz. bottle ...................\$ $\$ 0.25$

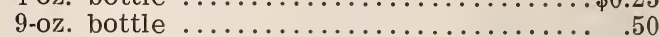

20-oz. bottle ....................... 1.00

1 -gallon can ........................... 1.75

\section{Butter Triers.}

Steel, Malleable Handles, 18 in. long......\$1.75 Steel, Japanned Handles, 18 in. long...... 2.00 Steel, Wood T Handles, 18 in. long........ 2.75

Cheese Color.

Hansen's Danish.

6-oz. bottle .....................\$0.25

1-gallon bottle ................ 2.00 


\section{Cheese Dressing. \\ Johnson's Fly Proof.}

25-pound pails, each.............\$2.75

\section{Cheese Triers.}

Steel, Japanned Hanules, 4 in. long, $1 / 2$ in.

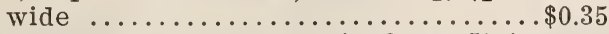
Steel, Japanned Handles, 5 in. long, $5 / 8$ in.

wide ....................... .75 Steel, Extra Finish, 5 in. long, $3 / 4$ in. wide, 1.15

\section{Cork.}

For Churn or Pasteurizer Covers.

Size, $1 / 2 \times 1 / 2$, best quality, per foot......\$0.10

\section{Fasteners (Tub).}

Plain Tin, per package.............\$0.50

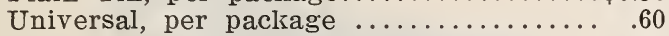

Acme Clasps, per pound............. .20

Lots of 25 pounds or over........... 17

\section{Gates (Perfection).}

$11 / 2$-inch Vat Gates...................\$1.75 3 -inch Weigh Can Gates.............. 3.00

\section{Heaters (Water).}

For use in wash-sinlis and vats to overcome noise and "pounding."

\section{Penberthy.}

$1 / 2$-inch Steam Connections, each.......\$1.00 $3 / 4$-inch Steam Connections, each........ 1.25

1 -inch Steam Connections, each........ 1.50

\section{McDaniel's.}

1-inch Steam Connections, Black........\$1.00 1-inch Steam, Galvanized............ 1.25

\section{Lace Leather.}

$1 / 4$-inch wide, per 100 feet..........\$0.75

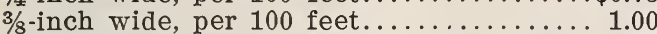
$1 / 2$-inch wide, per 100 feet............. 1.25 $5 / 8$-inch wide, per 100 feet............. 1.50

\section{Oils.}

We handle only the Best Grades. Satisfaction guaranteed.

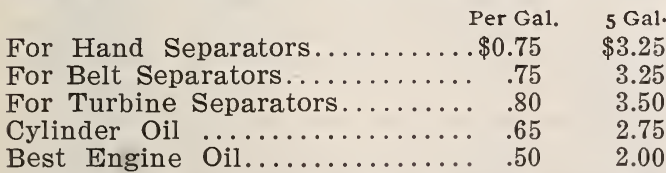

Best Engine Oil............... $.50 \quad 2.00$
The above prices include cans. prices on barrel lots.

Preservatives for Keeping Composite Tests. Stewart's Corrosive Sublimate Tablets, per

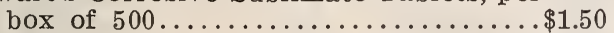
Composite Testing Preservaline No. 2, per

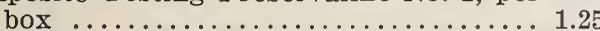

Punches-Drivers ............ to $\$ 1.75$

\section{Receiving Sheets.}

60 Patrons, 15 days, per doz...........\$0.75 130 Patrons, 15 days, per doz........... .75

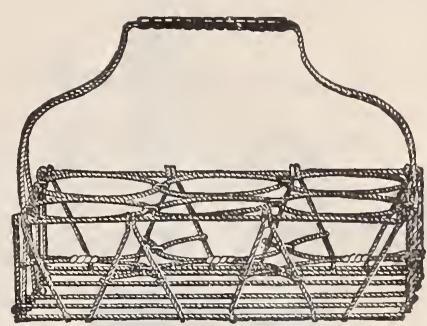

Delivery Baskets.

For delivering milk in bottles. Made from best Spring Steel. Light and strong. 4 Quarts, 2 Pints, each..............\$0.85

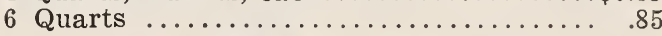

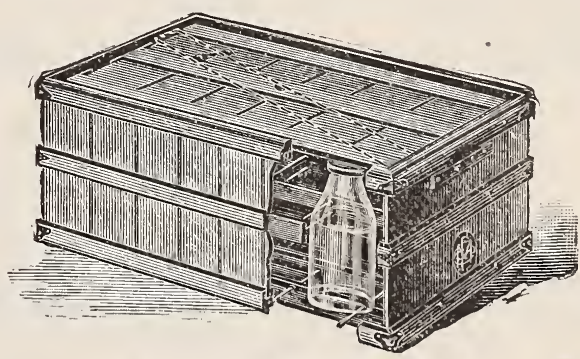

Milk Jar Cases or Carriers.

Wooden.

Light, strong, attractive and durable. The latest thing out. Arranged in three sizes. Has interlocking arrangement, so that any size can be tiered one above the other. Raclis fastened. Quart size holds 12 bottles; pint size, 15 bottles; and one-half pint size, 20 bottles.

Price, either size................ \$1.25

Crates with covers, furnished to order, 15 cents extra.

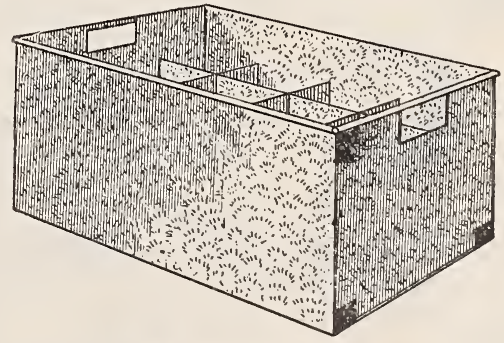

Galvanized Iron.

Especially desirable for use in warm weather, as crushed ice may be used around necks of bottles without fear of leakage from melting.

Made of No. 27 gauge galvanized iron, with heavy steel wire round top. Bottom is reinforced by two strips of band iron to protect case from wear when handling in and out of wagon.

Partitions made of galvanized iron and are removable, making cases easy to clean.

All seams are well soldered and case is made to stand hard usage.

The best delivery cases in use. Made in two sizes.

No. 1, holds 12 quart bottles, each.......\$1.75

No. 2, holds 15 quart bottles, each........ 2.00

No. 3 , holds 24 pint bottles, each.......... 2.00 Special sizes made to order. 


\section{BRUSHES.}

Babcock Test Bottle.

Each .......................\$0.10

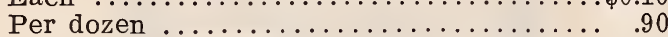

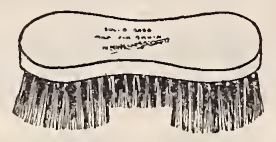

A. B. C. Tampico.

A four-inch brush, intended for small cans, bottle-fillers and other tinware where little scrubbing is necessary. Made from the best white Tampico.

Each ..........................\$0.20

Per dozen .....................2.00

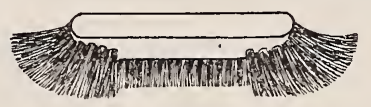

Jersey Palmetto.

Made from best selected Palmetto, well fastened to wooden backs, with tufts on ends, one of the best can and vat brushes on the market.

Each ........................\$0.30

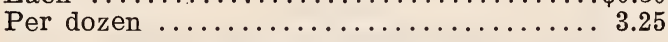

\section{Holstein Palmetto.}

This brush is the same as Jersey, except much heavier. Used principally in washing sinks and vats; is too large for cans, except ten-gallon size. We do not show cut of this brush.

Each ........................ \$0.35

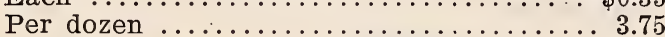

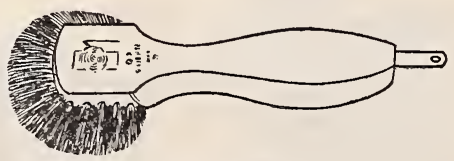

Gong Palmetto.

Made of same material as the Jersey; is a very popular can brush.

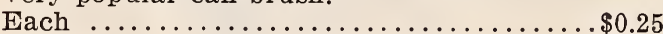

Per dozen .....................2.25

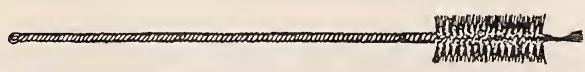

Test Tube.

This is a good bristle brush, with wire handle; made especially for cleaning test tubes.

Each ..........................\$0.25

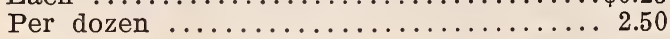

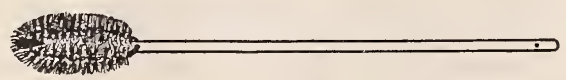

\section{Bottle Brushes.}

Have wood handle; can be used as a hand brush or with power bottle washer; is made of best bristles and will give satisfaction.

Each .........................\$0.25

Per dozen ..................... 2.50

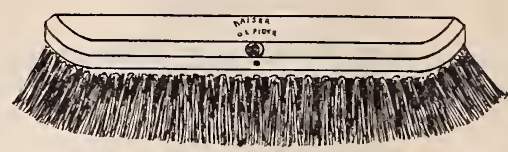

Kaiser Floor.

Made of best selected Palmetto, and will outwear any other floor brush on the market; preferable to broom for scrubbing factory floors.

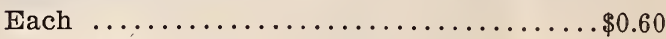

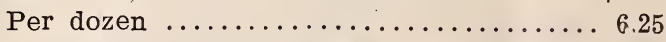

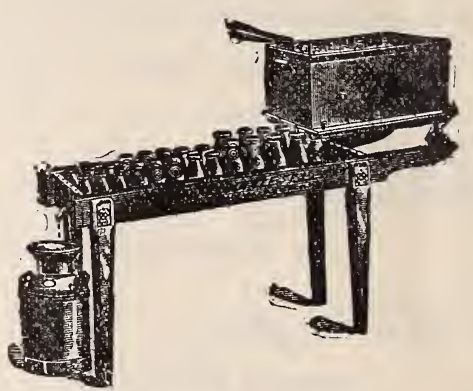

Ideal Bottle Filler.

Something every dairyman who sells bottled milk should have.

For a medium, low-priced Filler, one easily operated and cared for, we recommend the "Ideal."

It is substantially made and provided with a zinc-lined sink, with a holding capacity of 24 to 48 quart jars. A brass track is fitted on either upper edge of this sink, on which travel the wheels or trucks which support the tank platform. This platform is removable, as is also the tank, which rests on the same. When the tank is in position the flow tubes are directly over the jars. By pulling down the levers the milk flows rapidly into the jars until filled. The levers are then released and the tank, with truck is moved to the next set of jars and the operation repeated.

The tanks hold about 40 and 60 quarts and have the filling devices attached.

The machines' filling capacity is about 12 and 18 quarts a minute, filling two or four jars at once, but the attachment is so made that one jar can be filled at a time if so desired.

By the use of thumb-screws the attachments may be removed and all parts easily cleaned. The attachments are nickel plated. The valves are solid copper, over which rubber casings are placed.

\section{Sizes and Prices.}

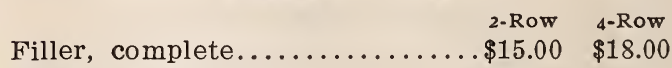

Fitted with removable attach-

ments for filling half pints or

pints .................... $16.50 \quad 20.00$

Fitted with removable attach-

ments for filling half pints or pints .................. 18.00 
BOTTLE CAPS.

For Common Sense Bottles.

Hustler.

Plain or Paraffined.

Per thousand $\ldots \ldots \ldots \ldots \ldots \ldots \ldots \ldots \ldots . \ldots 0.50$

Box of five thousand.

\section{Clover.}

Plain or Paraffined.

Per thousand

Box of five thousand.

\section{Health.}

Plain or Paraffined.

Per thousand ....................\$0.65

Box of five thousand............... 3.00

Special prices in barrels containing fifty thousand.

\section{THERMOMETERS.}

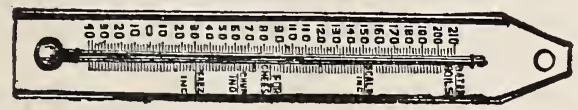

Flange Thermometer.

8-inch, each......\$ 0.25

8-inch, per dozen.... 2.50

10-in., Special Tested, .75

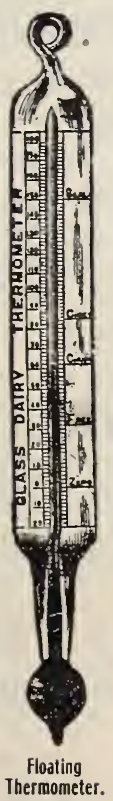

\section{Floating Thermometer.}

8-inch, each.......\$ \$0.25

8-inch, per dozen.... 2.00

Special, with large bulb to float above milk or cream.

Each $\$ 0.50$

Per dozen 5.00

Lactometer and Thermometer.

Combined,

Each ... \$1.25 and $\$ 2.00$

Lactometer only,

Each .... .40 and

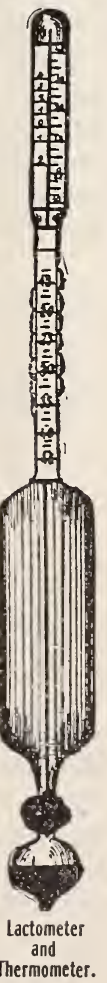

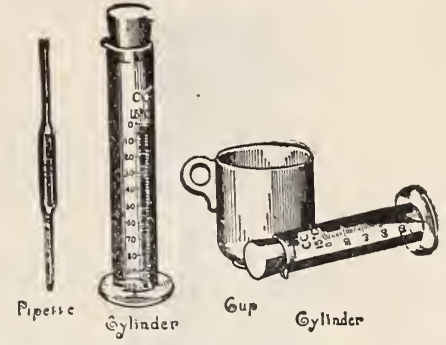

Farrington's Acidity Testing Outfit.

For testing Acidity of Milk or Cream.

Small outfit, complete, with 100 tablets,

20 c. c. vial and 17.6 c. c. pipette.....\$0.85

Large outfit, complete, with 1,000 tablets,

100 c. c. cylinder and 17.6 c. c. pipette, 2.75

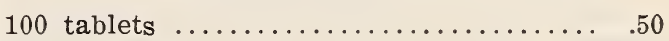

1,000 tablets ....................... 2.00

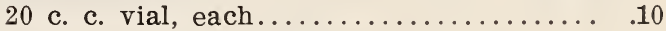

100 c. c. cylinder, each............... .95

17.6 c. c. pipette, each............... .25

GLASSWARE.

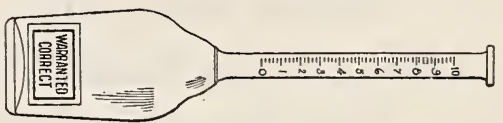

Babcock Test Bottles.

Testing bottles for whole milk, with Each Doz. frosted bulb for numbering..... \$0.25 $\$ 2.25$

Ohlsson's double-neck bottles for whole milk .............. .75 7.50

Wagner's double-neck bottles for skim milk .............. .75 7.50

Straight-neck bottles for cream, graduated to one-half per cent., 0 to 30 degrees, 0 to 40 degrees, 0 to 50 degrees..................

Bulb-neck bottle for cream, graduated to one-fifth per cent., 0 to 25 degrees, or one per cent. -0 to 50 degrees $\ldots \ldots \ldots \ldots \ldots \ldots \ldots \ldots . .30 \quad 3.50$ Acid measures, 17, 5 c. c.......... .20 2.00 Pipettes, 17.6 or 18 c. c.......... .25 2.50

\section{Glass Graduates.}

2-oz., each

4-oz., each

8 -oz., each $\ldots \ldots \ldots \ldots \ldots \ldots \ldots \ldots \ldots \ldots . .35$

16-oz., each .................. .45 


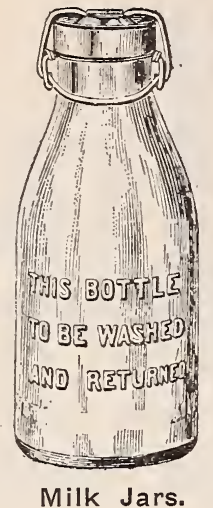

The strongest, best shaped bottle made. Clear flint glass.

Less than half a gross of a kind at dozen prices.

Full case lots, half gross in case, at gross prices.

In lots of five gross or more, 50 cents per gross less.

Lightning Tin Top Finish.

Per doz. Per gross Half pints, with Lightning tops...\$0.85 $\$ 8.00$ Pints, with Lightning Tops....... $1.00 \quad 10.00$ Quarts, with Lightning Tops..... $1.25 \quad 12.50$

\section{Lightning Tin Top Trimmings.}

Complete, with cover, spring and wire fasteners.

Per dozen .....................\$0.15

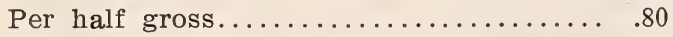

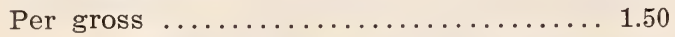

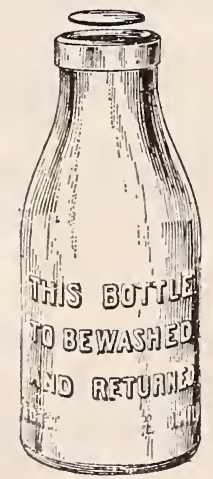

No. 2 Cap Finish.

Per doz. Per gross Half Pints, "Common Sense"....\$0.85 \$7.00 Pints, "Common Sense"......... $1.00 \quad 9.00$ Quarts, "Common Sense"....... $1.25 \quad 11.50$

\section{Special Name Plates.}

Can be furnished when five gross or over are ordered, at an additional cost of $\$ 3.00$ to cover cost of making mould.

\section{CURD KNIVES.}

These knives have no wood about them, except the handle.

Blades made of steel, ground to an edge and tinned over to prevent rusting.

\section{Horizontal.}

8 inches wide, 20 inches long......... \$5.00 12 inches wide, 20 inches long.......... 7.20

\section{Perpendicular.}

8-Blade Knives, 20 inches long........\$2.80 12-Blade Knives, 20 inches long........ 3.60

\section{Curd Mills.}

Pohl's Self-Salting.

The many advantages this mill has over any other curd mill in use may be briefly stated as follows :

First. The ease with which it can be operated, either by hand or power. It grinds and salts at one operation.

Second. That it thoroughly tears and pulverizes the curd instead of cutting or squeezing it.

Third. That the salter attachment is so arranged that the salt can be evenly distributed through all parts of the curd in exact proportion at the same time the curd is being ground. It salts all of the curd perfectly even.

Fourth. That it will not clog up and cut some of the curd fine and leave some coarse and stringy.

Fifth. The hoop can be placed under the mill to receive the curd as it passes through the mill, thereby saving any further trouble than to place the same immediately in the press. It will grind eight or ten cheeses in five minutes.

\section{Prices.}

Power Mill, complete with Salting Attach-

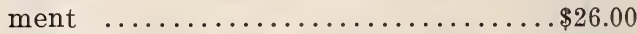

Power Mill, complete, without Salting At-

tachment ...................... 24.00 Shipping weight, $75 \mathrm{lbs}$.

\section{VETERINARY INSTRUMENTS.}

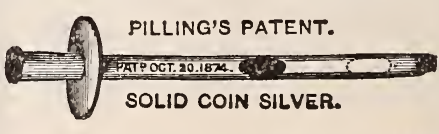

\section{Pilling's Coin Milking Tubes.}

For sore and obstructed Teats, and hardmilking cows.

$13 / 4$-inch, each ................ \$0.50

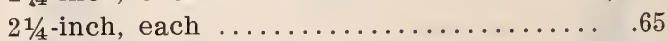

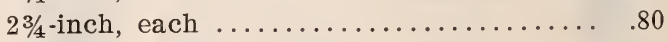

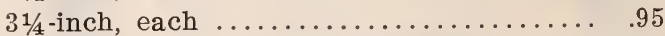

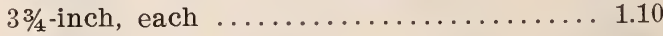

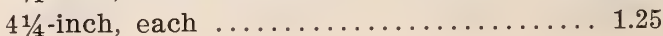


VETERINARY INSTRUMENTS-Continued.

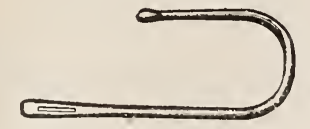

Lead Probe or Sound.

The Probes are to be oiled with Fluid Extract of Belladonna and inserted after each milking, after any operation has been performed with Teat.

Made in three sizes: Small, medium and large.

Any Size

.$\$ 0.25$

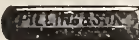

Pilling's Improved Instrument for Opening Obstructed Teats.

$4 \frac{1}{2}$ inches long, made of Coin Silver.

Each $\ldots \ldots \ldots \ldots \ldots \ldots \ldots \ldots \ldots \ldots \ldots \ldots+75$

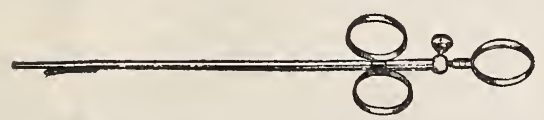

Pilling's Three-Ring Stricture Cutters.

For Cutting Strictures in Cows' Teats.

Each

Pilling's Plain Teat Slitter.

Solid Sterling Silver, each..........\$2.00

The above instruments securely packed in neat boxes, with full instructions how to use. Sent by mail, postage paid, upon receipt of price.

\section{Bull Punches or Trocars.}

For ringing bulls or punching bloated cattle.

Each ................... \$1.00

Bull Rings, polished copper, each....... .20

\section{MISCELLANEOUS TINWARE.}

For Dairy and Milk Dealers.

Dippers, Factory.

Made of Heavy Tin, and Well Soldered.

Short Handle, one gallon, each........\$0.75

Long Handle, one gallon, each ........ 1.00

Strainer, one gallon, each.............. .75

\section{Dippers, Measuring.}

For Dairymen and Milk Depots.

Half-pint Dipper, with long handle, each. .\$0.15 One-pint Dipper, with long handle, each... .15

One-quart Dipper, with long handle, each.. $\quad .20$

Small Dippers, for taking Composite

Tests, each ......................20

\section{Measures.}

One-quart measure, each............\$0.10

Heavy Quart Measure, graduated, each... .35

Two-quart Measure, light, each.......... .20

Two-quart Measure, heavy, each...........45

\section{skimmers.}

Cone Skimmers, with long handle.......

\section{STRAINERS.}

Milk.

Plain, medium size, each...........\$0.25

Plain, large size, each............ 1.00

More's Pyramid, each.................. 1.75

\section{Cream.}

Vat Cream Strainer, with Hardwood

Frame, each ................. \$4.00

\section{Churn Cream Strainers.}

In ordering, give size of opening and style of churn.

According to size, each........ $\$ 1.50$ to $\$ 3.00$

\section{Buttermilk.}

McLaren's, each ................\$1.00

\section{WEIGH CANS.}

Made of extra heavy XXXX Tin Plate. They have slanting bottoms; are all fitted with Perfection Gates.

\section{Plain.}

Holding 40 gallons, with 1 gate........ \$12.00 Holding 60 gallons, with 1 gate........ 14.00

\section{With Partition.}

Holding 60 gallons, with 2 gates......\$18.00

\section{CONDUCTOR HEADS.}

Our conductor heads are made extra strong and connected with a short piece of pipe for delivery.

When more lengths are required they are ar. ranged to telescope to head.

Heavy.

Made from XXXX Tin Plate.

Price, each .................\$3.00

\section{Light.}

For Dairy or Small Factory.

Price, each .................\$2.00

\section{Conductor Pipe.}

Made from XX Tin, in 2-ft. Lengths.

Price, 4-inch pipe, per foot.........\$0.30

\section{Curd Scoops.}

Made from Heavy Tin. The edges are wired and carefully soldered, making a strong scoop.

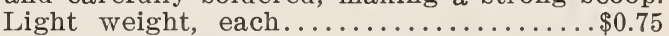

Heavy weight, each.............. .90

\section{Whey Strainers.}

Made from Best XXXX Tin Plate.

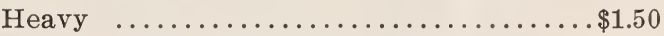
For either Channel or Flat-bottom Vats. In ordering, state which style is desired.

\section{Siphons.}

Used for drawing off whey or removing milk from one vat to another.

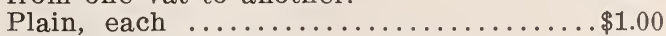

With gate and valve, each........... 2.00 


\section{B. Heller \& Co.'s Products for the Dairy.}

\section{"FREEZINE."}

A liquid which will keep Milk and Cream in a fresh condition, for one week, without the use of ice or cold storage. It is the only preserving agent manufactured which does not have any bad effect on the flavor or fresh appearance of milk and cream, and keeps it abso. lutely pure, s'weet and wholesome without changing the natural properties.

\section{THE ADVANTAGES OVER ICE.}

First. When Freezine is used it will keep the milk and cream perfectly sweet and fresh regardless of the climate or temperature of the room in which it is stored.

Second. Ice is not needed at all to keep milk and cream.

Third. It costs less than one-tenth as much to keep milk and cream with FREEZINE as it does with ice.

Fourth. It is much less work to use FREEZINE than ice, as only one-half to one tablespoonful is necessary to keep a ten-gallon can of milk fresh for 48 hours.

Fifth. When only ice is used the milk often sours, while with FREEZINE the milk is alwayis kept sweet, even during thunder storms.

Sixth. Milk treated with FREEZINE has been pronounced by some of the highest allthorities in the United States, to be more wholesome than milk stored in an ice-box and kept under the most favorable conditions.

FREEZINE prevents the disease germs breeding in milk. These germs, when allowed to multiply or increase, cause so much sichness among infants and small children.

\section{OUR THREE STRONG GUARANTEES.}

First. We guarantee FREEZINE to be entirely harmless to the human system.

Second. We guarantee FREEZINE to be far superior in every respect, and cheaper than any other preservative manufactured.

Third. We guarantee, if FREEZINE is not found exactly as represented, to cheerfully refund your money.

FREEZINE has now been in constant use for over six years, and during that time we have received thousands of testimonials from Dairymen, acknowledging FREEZINE to be of great value in their business, and that it has largely increased their trade, as their customer are never troubled with sour milk.

Many have now stated that they could not get along without it.

If you are not already using FREEZINE, order a bottle at once and try it. You can not afford to be in the milk business without it, and if you don't find it to do all we claim for it, we will cheerfully refund your money.

\section{HOW "FREEZINE" IS USED.}

For Milk, use one-half to one tablespoonful of FREEZINE to every ten gallon can; simply stir it into the milk. This quantity will keep the milk sweet and in good condition, without the use of ice, for 48 hours. If it is desired to keep the milk sweet a longer time, at the end of 36 hours, charge the milk again. One charge of FREEZINE will keep the milk sweet 48 hours; after that, if it has not been re-charged with FREEZINE, the milk will sour naturally.

\section{Price List.}

(These prices are Net-No Discount.)

Quart Bottles, each............... \$1.00 Half-gallon Bottles, each............ 2.00 Gallon Bottles ..................... 3.50 In lots of $1 / 2$ dozen gallon bottles, per gal., 3.30 In lots of 1 dozen gallon bottles, per gal., 3.20 In lots of $1 \frac{1}{2}$ dozen gallon bottles, per gal., 3.15 In lots of 2 dozen gallon bottles, per gal., 3.10 In lots of 4 dozen gallon bottles, per gal., 3.00

Freezine is put up only in Quart, Half-gallon and Gallon Bottles, and is not sold in Bulk.

\section{CREAM THICKENER.}

B. Heller \& Co.'s Cream Thickener enriches and thickens cream, and makes it delicious and nutritious. The fatty globules are evenly and perfectly distributed, so that the cream is uniformly rich from top to bottom.

The Dairyman Who Gives His Customers Thick, Rich Cream, Wins the Battle. He has no trouble satisfying and holding his trade, and is continually getting new customers.

To give milk and cream a rich, June tint, use B. Heller \& Co.'s Eagle Brand Milk and Cream Color.

\section{Formula for Making Thick Cream.}

3 gallons of Thin Cream, 1 gallon of Milk or Water, $13 / 4$ oz. Cream Thickener, make 4 gallons of Rich, Heavy Cream. You gain 33 1-3 per Cent. Profit. Pays for itself many times over.

ADDS TO CREAM quality, quantity, nutritive value, and produces a fine, rich cream, which gives much better satisfaction to the consumer. Easy to use. Full directions sent with each package.

\section{Price List.}

(These Prices are Net-No Discount.)

1-pound cans, each................ $\$ 1.50$

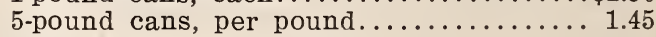
10 -pound cans, per pound............. 1.40

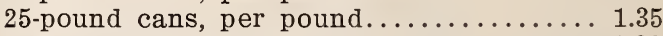

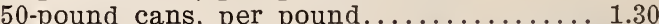

Order a trial can and if not found exactly as represented, your money will be cheerfully refunded.$$
\text { “OZO." }
$$ \\ FOR THE DAIRY.}

An Invaluable Sterilizing Preparation for the proper washing, cleansing and purifying of Dairy Utensils, Milk Cans and Bottles, and for all purposes where a thoroughly effective cleansing and antiseptic agent is required.

\section{Price List.}

5-pound boxes, per pound..........10c

10 -pound boxes, per pound...........

25 -pound kegs, per pound........... 8c

50 -pound kegs, per pound.......... $71 / 2 \mathrm{c}$ 100 -pound kegs, per pound........... 300 -pound barrels, per pound.........6c

WRITE FOR SPECIAL CATALOGUE. 


\section{PASTEUR BLACKLEG VACCINE.}

For protecting cattle against Blackleg. We furnish the original and genuine article made by the discoverers, and which has been largely and successfully used since 1884 . Over 3,000,000 calves have been successfully protected against Blackleg with our vaccines since 1895 in the United States and Canada. We furnish our Blackleg Vaccines both in the old powder form and in the more modern and convenient Cord form ready for use. Both are supplied for "Single" and for "Double" treatment.

\section{POWDER FORM.}

Pasteur Single Blackleg Vaccine, price $\$ 1.50$ per packet, sufficient for from 10 to 12 head; Pasteur Double Blackleg Vaccine, $\$ 2.00$ per double packet (first lymph and second lymph) for 10, 15 or 20 head, according to age. Pasteur Blackleg Vaccinating Syringe Outfit, consisting of pestle, mortar, funnel, filters, graduate and syringe with trocar, needles, canulas, etc., complete in case, $\$ 6.00$. This Syringe Outfit is required with powder form vaccine. The principal instrument is the syringe and ours is especially adapted for Blackleg Vaccination.

\section{"BLACKLEGINE."}

\section{PASTEUR BLACKLEG VACCINE-QUITE READY FOR USE.}

This is in the form of a cord impregnated with the vaccine. Each dose is separate and applied with a special needle. The dose is hitched on to a notch in the needle and then inserted under the skin at the shoulder. The needle is provided with a detachable handle. Vaccination with "Blacklegine" is as rapid and easy as taking a stitch. There is no dissolving, or mixing, or filtering a powder; no injecting or trouble in measuring doses; No Expensive Syringe Outfit or Injector.

\section{PRICES.}

"Single Blacklegine" (for common stock): No. 1 (ten-dose package), $\$ 1.50 ;$ No. 2 (twenty-dose package), $\$ 2.50$; No. 3 (fifty-dose package), $\$ 6.00$. “Double Blacklegine" (for choice stock-first lymph and second lymph, applied at an interval of eight days), $\$ 2.00$ per packet of ten double doses.

Blacklegine Outfit (handle and two needles), 50 cents.

The vaccinal cord is patented in the United States, Canada and other countries.

Made by PASTEUR VACCINE COMPANY, Ltd.

\section{PARKE, DAVIS \& COMPANY'S \\ LIST OF PRICES ON \\ Blacklegoids and Blacklegoid Injectors.}

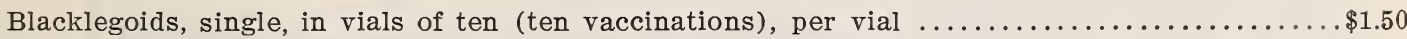
Blacklegoids, single, in cases containing five vials of ten Blacklegoids each (fifty vaccinations

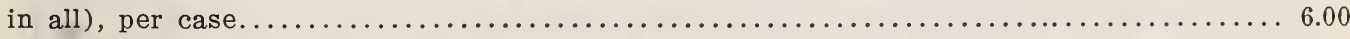
Blacklegoids, double, in cases containing two vials of ten Blacklegoids each (ten double vaccina-

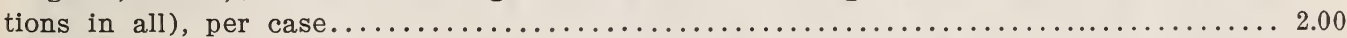
Blacklegoids, double, in cases containing five vials of ten Blacklegoids No. 1, and five vials of ten Blacklegoids No. 2 (fifty double vaccinations in all), per case................. 8.00

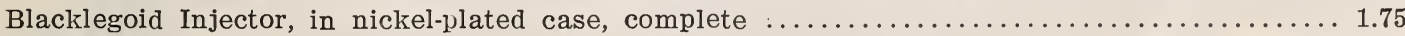

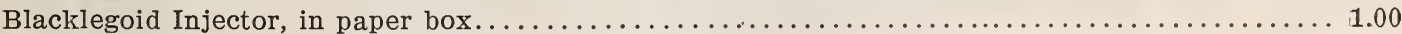




\section{KEYSTONE DEHORNER.}

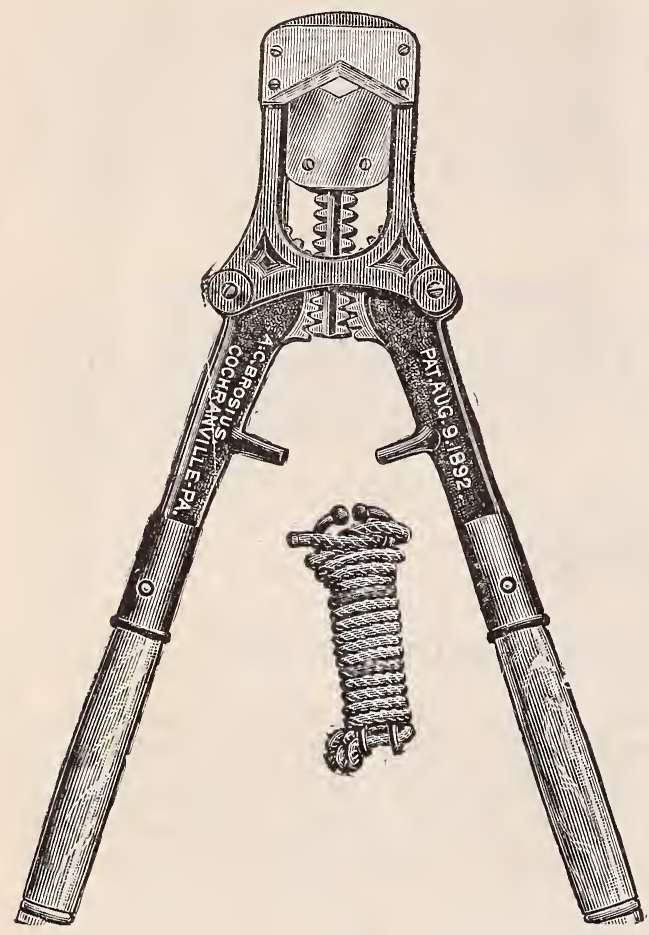

IN FAVOR OF DEHORNED CATTLE.

The Keystone Clipper can be used readily by one having had no experience and is done with such leverage power as to be practicable for all horns, and one of the greatest advantages is that it cuts clear and clean with no crushing. In proof that dehorning does not affect the animal physically, we would state that in all instances where food or drink is offered immediately after the operation, they do not refuse to take it; also let us state that there is no falling off in quantity of milk that is noticeable, and after the first milking there is mostly an increase. All agree that the quieter cattle are kept for both dairy and beef purposes, the more profitable they are, and those having had experience are unanimously in favor of dehorned cattle.

Price of Complete Outfit:

The Keystone Dehorning Clipper Leader, and Rope, Extra Blades and Screws. Warranted........................

Clipper alone, \$10.00.

HOW TO ORDER.

In sending us your order, it is to the customer's advantage, as well as ours, to send cash with order and save extra expressage. When money does not accompany the order, we will send C. O. D., if satisfactory references are given. We endeavor to have all dealings satisfactory to our customers.

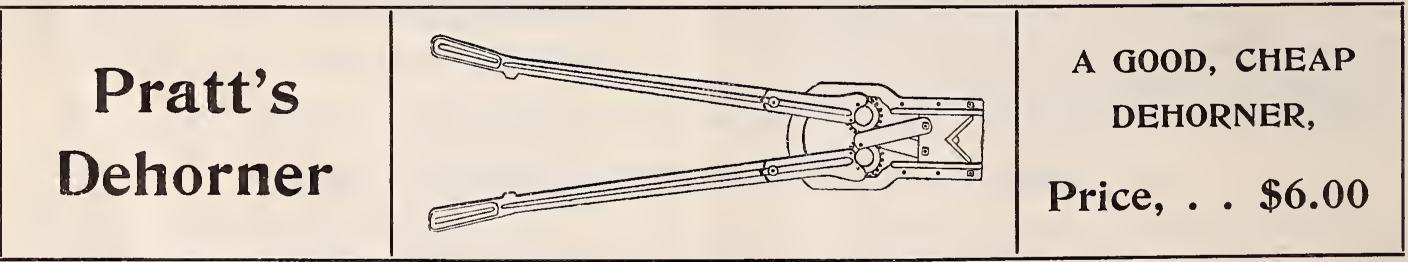

WE ARE ONE OF THE LARGEST MANUFACTURERS OF PITCH, TARRED PAPER, COAL TAR, PREPARED ROOF AND BUILDING PAPERS AND ALL KINDS OF ROOF PAINT AND ELASTIC, BITUMEN AND ASPHALTUM IN THE WEST.

WE HANDLE PLASTER, PLASTERING HAIR AND CEMENT, AND SELL AT THE LOWEST MARKET PRICES.-WRITE FOR PRICES. WRITE FOR SPECIAL CATALOGUE. 


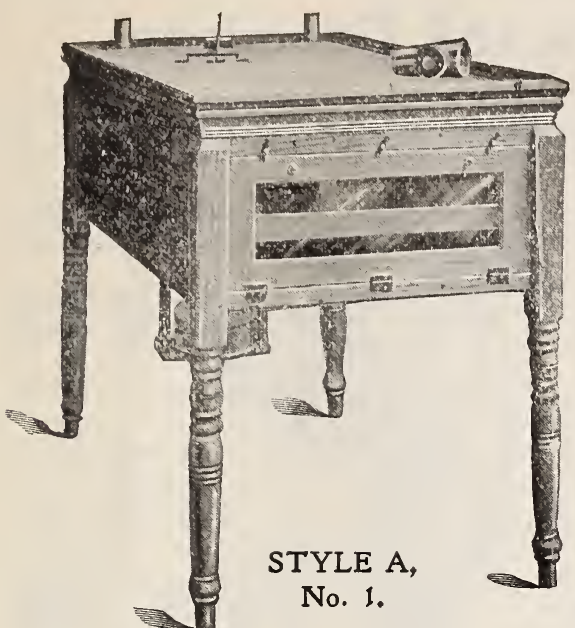

\section{PRAIRIE STATE INCUBATORS.}

We are the Western Agents of the Prairie State Incubators, and carry a large and complete stock of the different styles.

The quality and workmanship on the Incubators and and Brooders are fully guaranteed. We have handled them for the last five years, and they have given the best of satisfaction.

Write for special catalogue.

\section{BROODERS.}

Indoor Brooders.

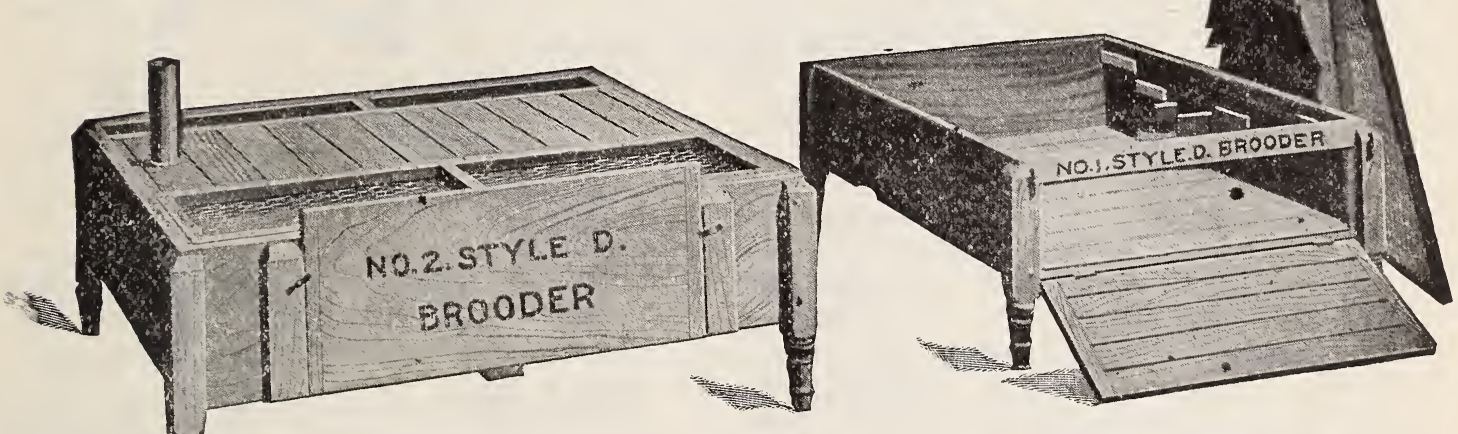

STYLE D, No. 2

STYLE D, No. 1

Outdoor Brooders.

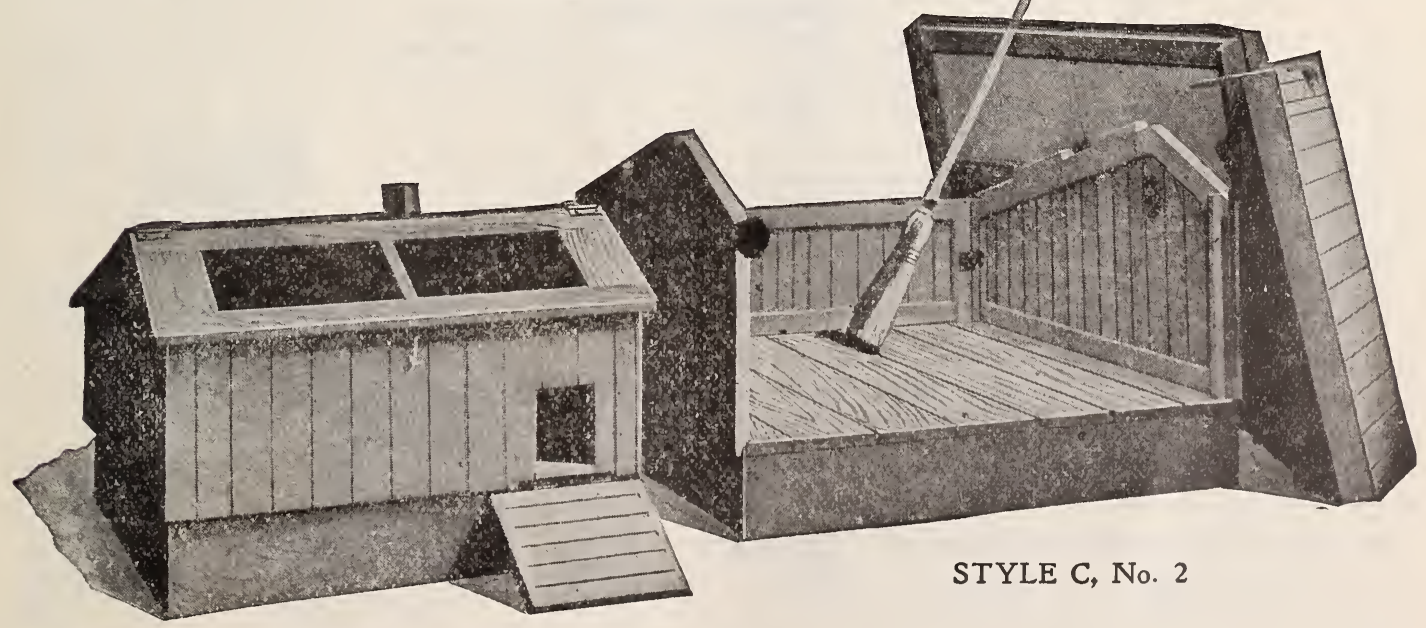

STYLE C, No. 1

SEE NEXT PAGE FOR PRICE LIST. 


\section{Price List of Incubators and Brooders}

We warrant every machine we sell to be constructed of the very best material, finely finished, selfregulating, and so built that it will last a lifetime-in short, to be first-class in every respect. If purchasers do not find the machines exactly as advertised, we bind ourselves to refund the money paid for them.

Our prices are lower for the standard of work we maintain than those of any other manufacturer. We have a standing offer of $\$ 1,000$ in Gold to any manufacturer who makes and sells as good an incubator as the Prairie State, for so little money.

The prices quoted below are net cash with order. We make no discounts and have no special terms. In remitting, send bank draft, certified check, express money order or postoffice money order on Denver, Colorado.

PRAIRIE STATE "SPECIALS."

\begin{tabular}{|c|c|c|c|c|c|c|c|}
\hline \multirow{2}{*}{ No. } & \multirow{2}{*}{ DIMENSIONS } & \multirow{2}{*}{ CAPACITy } & \multirow{2}{*}{$\begin{array}{l}\text { WEIGHT, } \\
\text { CRATED } \\
\text { LBS. }\end{array}$} & \multicolumn{2}{|c|}{ WEIGHT, BOXED } & \multirow{2}{*}{$\begin{array}{c}\text { CUBIC } \\
\text { CoNTENTS } \\
\text { CUBIC HT. }\end{array}$} & \multirow{2}{*}{ Price } \\
\hline & & & & Gross & Net & & \\
\hline $\begin{array}{l}0 \\
1 \\
2 \\
3 \\
4\end{array}$ & $\begin{array}{l}15 \frac{1}{2} \times 26 \frac{1}{2} \\
23 \times 34 \frac{1}{2} \\
28 \frac{1}{2} \times 50 \\
28 \frac{1}{2} \times 70 \\
28 \frac{1}{2} \times 95\end{array}$ & $\begin{array}{l}60 \text { to } 65 \text { eggs } \\
110 \text { to } 120 \text { "، } \\
220 \text { to } 240 \text { "، } \\
330 \text { to } 360 \text { " } \\
440 \text { to } 480 \text { " }\end{array}$ & $\begin{array}{r}80 \\
135 \\
240 \\
350 \\
425\end{array}$ & $\begin{array}{l}110 \\
188 \\
296 \\
330 \\
450\end{array}$ & $\begin{array}{r}80 \\
110 \\
169 \\
225 \\
325\end{array}$ & $\begin{array}{l}8 \\
12 \frac{1}{4} \\
23 \frac{1}{3} \\
34 \\
43 \frac{2}{3}\end{array}$ & $\begin{array}{r}\$ 13.50 \\
20.00 \\
31.50 \\
41.00 \\
55.00\end{array}$ \\
\hline 288 Duck & $36 \times 68$ & $\left\{\begin{array}{l}\text { Duck eggs, } 288 \\
\text { Hen }\end{array}\right\}$ & 425 & 400 & 289 & $45 \frac{1}{2}$ & 48.00 \\
\hline Goose machine & $31 \times 18 \frac{3}{4}$ & 50 eggs & 160 & 200 & 124 & $15 \frac{2}{3}$ & 27.50 \\
\hline
\end{tabular}

PRAIRIE STATE “BABIES."

\begin{tabular}{|c|c|c|c|c|c|c|c|}
\hline $\begin{array}{l}1 \\
2\end{array}$ & $\begin{array}{l}14 \frac{1}{2} \times 24 \\
19 \frac{1}{2} \times 31\end{array}$ & $\begin{array}{c}50 \text { eggs } \\
100\end{array}$ & $\begin{array}{l}45 \\
70\end{array}$ & $\begin{array}{l}51 \\
83\end{array}$ & $\begin{array}{l}32 \\
42\end{array}$ & $\begin{array}{l}3 \frac{1}{4} \\
6 \frac{1}{3}\end{array}$ & $\begin{array}{r}6.75 \\
10.75\end{array}$ \\
\hline \multicolumn{8}{|c|}{ PRAIRIE STATE "STYLE A." } \\
\hline $\begin{array}{l}1 \\
2\end{array}$ & $\begin{array}{l}27 \times 37 \\
27 \frac{1}{2} \times 47\end{array}$ & $\begin{array}{l}150 \text { eggs } \\
210\end{array}$ & $\begin{array}{l}170 \\
215\end{array}$ & $\begin{array}{l}228 \\
247\end{array}$ & $\begin{array}{l}130 \\
160\end{array}$ & $\begin{array}{l}15 \frac{2}{3} \\
20\end{array}$ & $\begin{array}{l}22.50 \\
29.00\end{array}$ \\
\hline \multicolumn{8}{|c|}{ PRAIRIE STATE “STYLE B." } \\
\hline $\begin{array}{l}1 \\
2\end{array}$ & $\begin{array}{l}27 \times 37 \\
27 \frac{1}{2} \times 47\end{array}$ & $\begin{array}{l}150 \text { eggs } \\
210\end{array}$ & $\begin{array}{l}150 \\
195\end{array}$ & $\begin{array}{l}198 \\
244\end{array}$ & $\begin{array}{l}119 \\
157\end{array}$ & $\begin{array}{l}13^{\frac{2}{3}} \\
18^{\frac{2}{3}}\end{array}$ & $\begin{array}{l}16.50 \\
24.50\end{array}$ \\
\hline
\end{tabular}

\section{BROODERS}

STYLE D, HOT-AIR INDOOR BROODERS.

\begin{tabular}{|c|c|c|c|c|c|c|c|}
\hline $\begin{array}{l}1 \\
2\end{array}$ & $\begin{array}{l}25 \frac{3}{4} \times 36 \\
36 \times 36 \frac{1}{2}\end{array}$ & $\begin{array}{l}80 \text { chicks } \\
125\end{array}$ & $\begin{array}{l}60 \\
85\end{array}$ & $\begin{array}{l}71 \\
95\end{array}$ & $\begin{array}{l}39 \\
58\end{array}$ & $\begin{array}{l}6 \frac{2}{3} \\
8 \frac{1}{4}\end{array}$ & $\begin{array}{r}8.00 \\
10.00\end{array}$ \\
\hline \multicolumn{8}{|c|}{ STYLE C, HOT-AIR OUTDOOR BROODERS. } \\
\hline $\begin{array}{l}1 \\
2\end{array}$ & $\begin{array}{l}36 \\
48 \quad 36 \\
\times 48\end{array}$ & $\begin{array}{l}100 \text { chicks } \\
150\end{array}$ & $\begin{array}{l}125 \\
185\end{array}$ & $\begin{array}{l}158 \\
263\end{array}$ & $\begin{array}{r}93 \\
146\end{array}$ & $\begin{array}{l}15 \frac{1}{3} \\
26 \frac{1}{2}\end{array}$ & $\begin{array}{l}13.50 \\
18.50\end{array}$ \\
\hline \multicolumn{8}{|c|}{ STYLE B, SECTIONAL HOT-WATER PIPE BROODERS. } \\
\hline \multirow{2}{*}{ No. } & \multirow{2}{*}{$\begin{array}{l}\text { DIMENSIONS EACH } \\
\text { SECTIUN }\end{array}$} & \multirow{2}{*}{ CAPACITY } & \multirow{2}{*}{$\begin{array}{c}\text { WE GHT, } \\
\text { CRATED, } \\
\text { L.BS. }\end{array}$} & \multicolumn{2}{|c|}{ WEIGHT, BOXED } & \multirow{2}{*}{$\begin{array}{c}\text { CUBBIC } \\
\text { CONTENTS, } \\
\text { CUBICFT. } \\
\end{array}$} & \multirow{2}{*}{ PRICE } \\
\hline & & & & Gross & Net & & \\
\hline 2 & Two sections $36 \times 36$ & 200 chicks & 210 & 310 & 160 & $33 \frac{2}{3}$ & $\$ 21.00$ \\
\hline 3 & Three " $36 \times 36$ & 300 & 310 & $4: 0$ & 230 & $4 \hbar \frac{1}{2}$ & 26.50 \\
\hline 4 & Four " & 400 & 410 & 577 & 300 & $57 \frac{2}{3}$ & 31.00 \\
\hline
\end{tabular}




\section{MANN'S BONE CUTTERS.}

THE BEST GREEN BONE CUTTER MANUFACTURED.

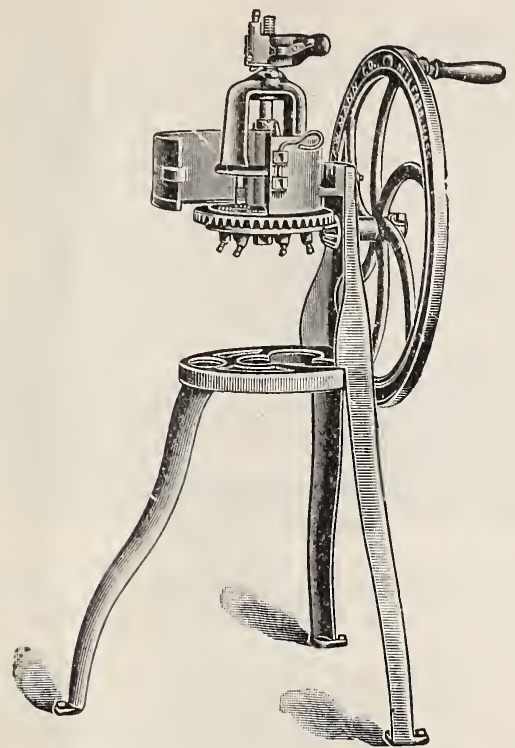

MANN'S 1903 MODEL BONE CUTTER NO. 7.

Intended for flocks of 40 to 100 hens; can be used profitably on a 100 or more.

\section{NO. 5 B. M.}

Intended for flocks of 15 to 25 hens. Can be used for flock of 100 hens, but larger size is more economical in the end for such a large flock. Mounted on iron stand, no expense to set it up. Place for pan to catch the bone. Patented automatic governing spring feed.

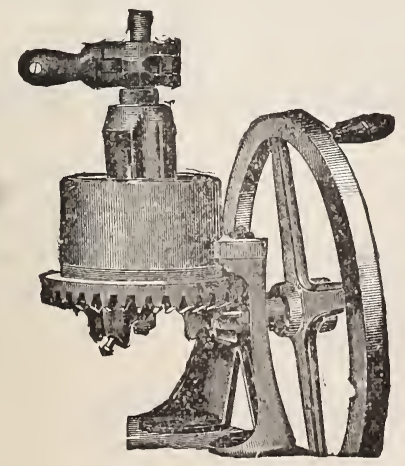

NO. 5 B.
NO. $5 \mathrm{C}$.

This machine is exactly the same as the No. $5 \mathrm{~B}$, with a crank handle instead of a balance wheel, and is only recommended when the strictest economy must be practiced. The small difference in the price is more than offset by the ease of operation produced by the momentum of the balance wheel. Capacity not quite equal to $5 \mathrm{~B}$. Weight, $35 \mathrm{lbs}$.

NO. $71 / 2,1903$ MODEL.

A combination hand or power Bone Cutter. Adapted to run either way without changing any part. It is always ready for use. Intended to meet the demand for a small power cutter. Cylinder same size as No. 7 .

Capacity, 50 to 100 lbs. per hour. Weight, 150 lbs.; diameter of the pulley, $11 \frac{1}{2}$ inches, $23 / 4$-inch face. Speed of pulley, 300 revolutions per minute. The No. $7 \frac{1}{2}$ has all the late improvements, special feed, anti-clog, open cylinder, tight and loose pulley, etc.

NO. 9, 1903 MODEL.

Intended for flocks of 100 to 300 hens. The description of No. 7 will apply to this size also. The difference consists of larger cylinder, greater holding capacity, different design and larger table. This machine can be altered into the No. 11 (see below) by adding the power parts, making a combination machine for both hand and power. Its economy is evident.

Weight, $170 \mathrm{lbs}$; cylinder, 9 inches in diameter; 6 inches deep. Capacity, $3 / 4$ to $1 \frac{1}{4} \mathrm{lbs}$. per minute.

NO. 11, 1903 MODEL.

Intended for large flocks when the machine must be run by hand a portion of the time. It is really a semi-power and semi-hand, or combination machine, and as such, has its place. But for an all-power machine we recommend the No. 12. The No. 11 is exactly the same as the No. 9, with the power parts added. It has all the late improvements, special feed, anti-clog, open cylinder, tight and loose pulleys, etc.

Weignt, 215 lbs.; diameter of pulley, 15 inches; $3 \frac{1}{2}$-inch face; speed of pulley, 300 to 350 revolutions per minute; cylinder same size as No. 9. Capacity, 100 lbs. and upward per hour.

IT IS ECONOMY TO BUY THE BEST, ESPECIALLY WHEN THE BEST COSTS NO MORE THAN UNTRIED MACHINES. 


\title{
MANN'S CLOVER CUTTER FOR POULTRY.
}

\author{
MADE ENTIRELY OF IRON AND STEEL-CAN NOT \\ WARP OR SHRINK.
}

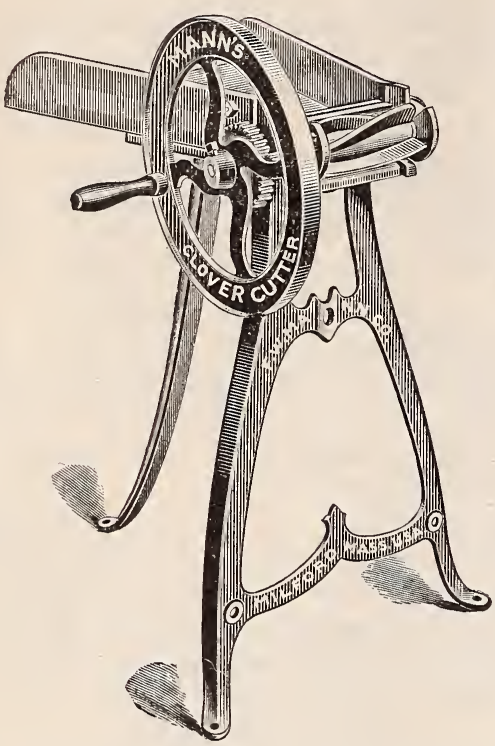

This machine is designed upon strictly correct mechanical principles, for the particular purpose of making the knife easy to sharpen and simple to adjust, and that will not get out of order, something never before accomplished. The importance of these points can be fully realized only when contrasted with other clover cutters, so complicated as to require an expert to either sharpen or adjust them. Another strong feature of Mann's Clover Cutter lies in the fact that it has but one straight knife to be cared for, made of the finest steel, securely fastened to a plate that can be set with positive accuracy, and yet can be removed in an instant. It cuts any kind of hay or clover, either dry or green, and more rapidly than any other. Every revolution of the balance wheel produces twelve cuts, which is four times as fast as the ordinary clover cutter.

It is strongly built. The workmanship is first-class in every particular, and it will last for years without repairs. It is not a toy or a rattle-trap, but a thoroughly practical machine offering the greatest value for the least money. Do not buy a clover cutter until you have seen the Mann's. Made either with or without the stand.

\section{CASH PRICE LIST. \\ Bone Cutters.}

No. 5 C, with Crank Handle..........\$ 6.75

No. 5 B, with Balance Wheel............. 9.75

No. 5 B. M., with Balance Wheel and Iron

stand $\ldots \ldots \ldots \ldots \ldots \ldots \ldots \ldots \ldots \ldots \ldots . \ldots \ldots$

No. 7, with Balance Wheel and iron stand, 14.00

No. $7 \frac{1}{2}$ Semi-Power Machine.......... 18.50

No. 9, with Balance Wheel and Iron Stand 20.50

No. 11 Power Machine.............. 30.00

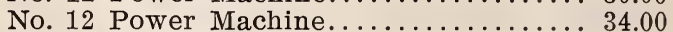

No. 15 Power Machine............... 65.00

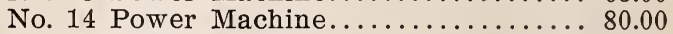

No. 16 Power Machine.............225.00

\section{Clover Cutters.}

Clover Cutter B, with Balance Wheel.. 9.00 Clover Cutter B. M., with Balance Wheel,

on Iron Stand .................. 11.00 Mortar ........................ 3.50

Parts to Change No. 9 to No. 11 ....... 8.50 Write for Special Catalogues.

\section{BLOOD MEAL.}

Deodorized Blood Meal is known to be the greatest Egg Producer there is. It is one of the cheapest foods existing. One pound is equal to fifteen pounds fresh meat. $3 \mathrm{lbs} ., 25 \mathrm{c}$; 10 lbs., 70c; 25 lbs., $\$ 1.50 ; 100$ lbs., $\$ 4.25$.

\section{GROUND MEAT AND BONE.}

This is a fine feed to give to Broilers. It fattens and strengthens, and every poultry yard should have a supply. 10 lbs., 50c; 25 lbs., $\$ 1.00 ; 50$-lb. sack, $\$ 1.65 ; 100$-lb. sack, $\$ 3.00$.

\section{NICTO NAPTO LICE KILLER.}

One of the best Lice Killers there is on the market. Especially adapted for use on young chickens. Regular size can, 25c; by mail, $35 \mathrm{c}$; 5-lb. can, $\$ 1.00$, not prepaid.

\section{CRUSHED OYSTER SHELL.}

Our crushed shell is the best there is and it is one of the most important feeds to be used in the poultry yard. 5-lb. pkg., 15c; 10-1b. pkg., 25c; 25-lb. sack, 50c; 100-lb. sack, $\$ 1.40$; two 100 -lb. sacks, $\$ 2.50$.

\section{FERTILIZER.}

For lawn and garden. Composed mainly of bone-dust. v0-1b. sack, $\$ 1.00 ; 100-1 b$. sack, $\$ 1.50$. 


\section{BEE SUPPLIES.}

THE COLORADO PORTICO HIVE.

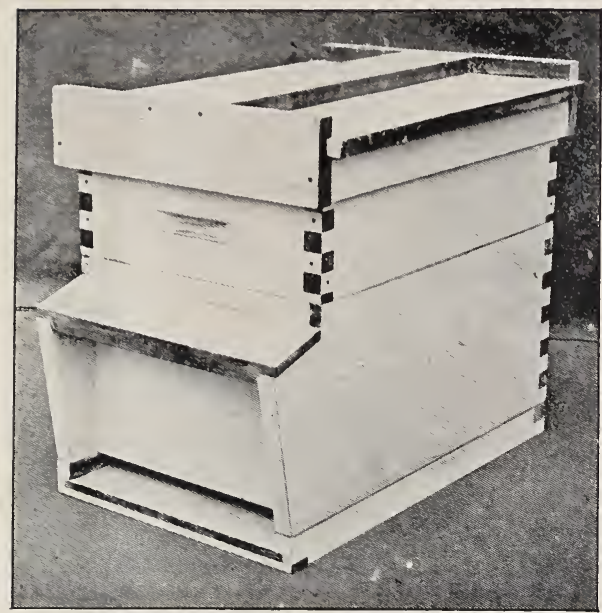

These are two of the most popular hives we carry. The Colorado Hive is adapted espec-
ROOT'S DOVE-TAILED HIVE.

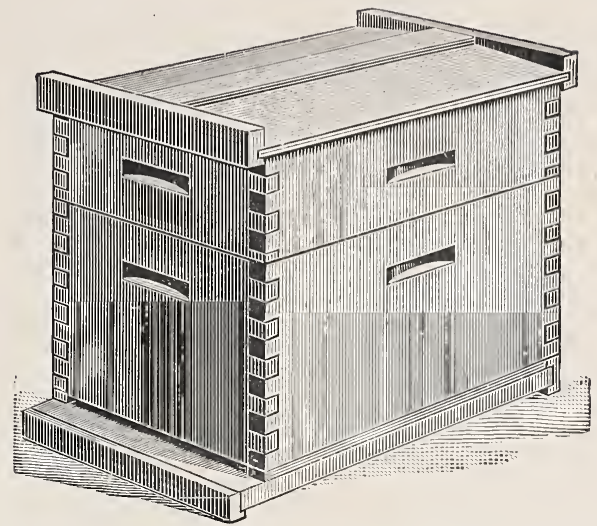

ially for this market. The quality and workmanship are of the best.

We carry the largest stock of Bee Supplies to be found in the west. We are State Agents for the A. I. Root Co. Write for special catalogue and price list.

WRITE FOR SPECIAL CATALOGUE.

\section{SALT OF ALL KINDS.}

Lump Rock Salt, Ground Rock Salt, Coarse and Fine Barrel Salt, Sulphurized Salt, Dairy Salt in any Quantity.

\section{SHEEP AND CATTLE DIP} BLACK LEAF TOBACCO EXTRACT, SKABCURA, ZENOLEUM, CHLORO NAPHOLEUM, COOPER'S SHEEP DIP, LIME AND SULPHUR, SPIRITS OF PINE TAR MIXTURE.

WE CARRY A FULL LINE OF STOCK-GROWERS' SUPPLIES OF EVERY DESCRIPTION.

WRITE FOR PRICES AND CATALOGUES.

WOOL-GROWERS' SUPPLIES,

WOOL SACKS, WOOL TWINE, SHEEP SHEARS, SHEEP CROOKS.

WRITE FOR PRICES. 


\section{Everything for the}

\section{farm and Garden}

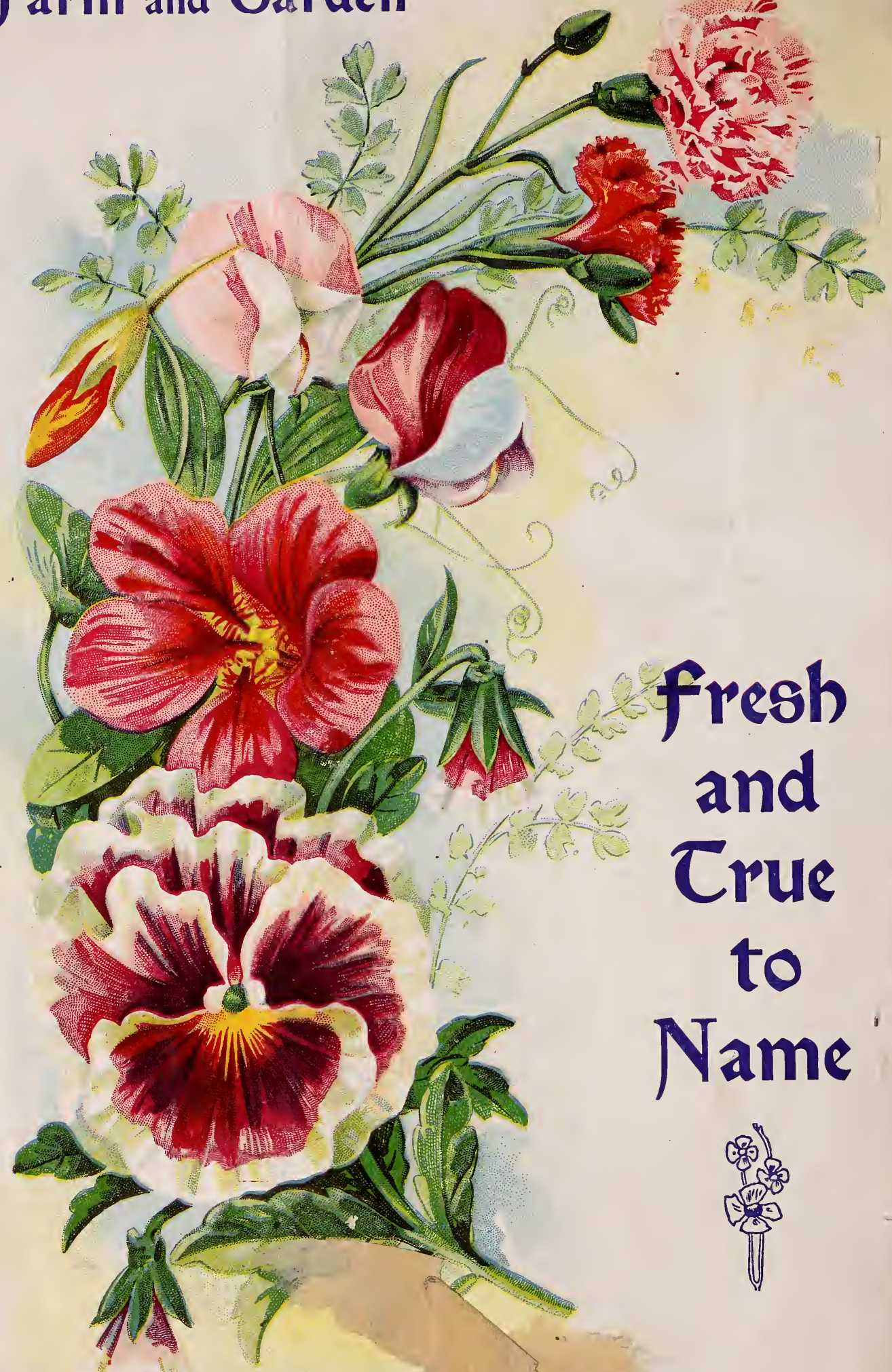

Che I. A. Calatkin: x. Co. Denver, Colo. 